\title{
昭和 30 年度における重要な燃料関係事項
}

燃料協会編集

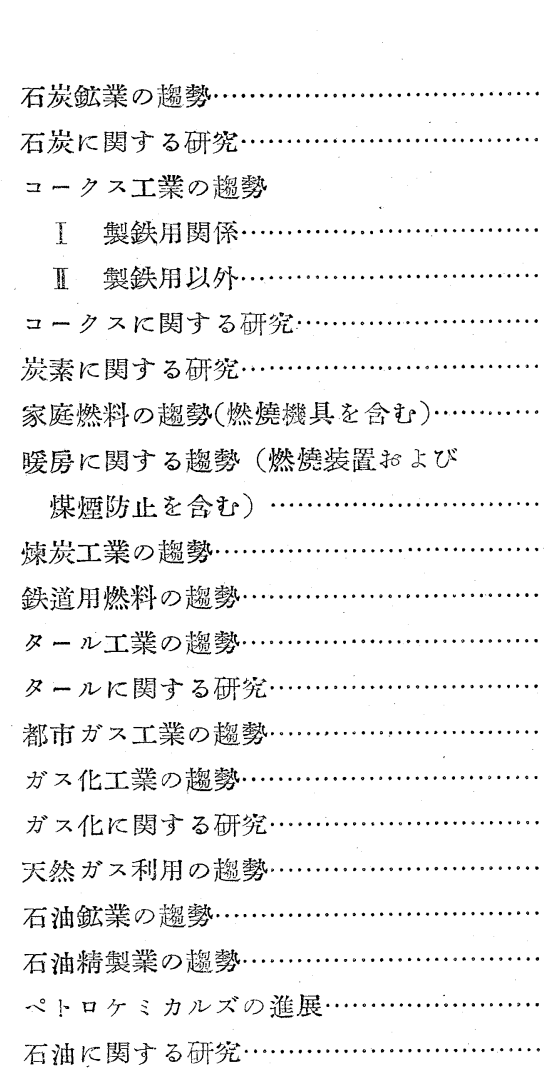

目

(178)

\section{石炭鉱業の超勢}

1。総 説 昭和 30 年は,一言にしていえぱ，朝 鮮動乱終熄以来の永い深刻な石炭鉱業の不沅が漸く底 在つき，立㨁りの機会に惠まれんとする転機の年であ つた。

前年から引続いて需要の不振, 重油, 外国炭の圧力 の下で，最低経済出炭規模年 4,600万tに対し，実際 の出炭は 4,100万 $\mathrm{t}$ 心゙ースに抑制せざるを得ない状態 で，従つてコストの切下げ不可能のまま何時まで続く かわからない赤字売炭に, 企業の存立を根底から摇す ふららていたのが 30 年前半の石炭鉱業の姿であつた。 6.月, 日本石炭協会がいわゆる石㞸白畫『石㞸鉱業の現 状』を発表して，炭界の当面する深刻な苦悩を訴えたの はこういう状況の下においてであつたのである。国と

\section{次}

潤滑油に関する研究 (220)

內燃機関の龪勢.

ガスタービンの進展

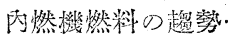

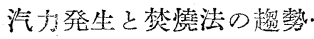

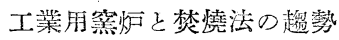

I 鉄鋼関袮

II 鉄銅関俰以外

然堯に関する研究。

選炭工業の趨勢

選炭に関する研究.

熱管理運動の趨勢.

熱管理に関する磁究

動力源の調查開発に関する情勢

原子力利用の遛勢(ラジオアイソトープ

の利用を含む)

地熱発電の䞶勢

太隄熱利用の䞶勢

燃料に関する会合

燃粘に関する規格

燃料に関する新匜書

してもかかる状態学徒らに成行に委して放任すること が許されない段階に志できたのが，石㞸鉱業合理化臨 時拱置法, 重油ボィラーの設置の制限などに関卞る臨 時掅置に関する法律，関税定率法などの一部を改正す る法律(彷来の重泊関税免税の時例莡廃上儿, 原油2\%, B，C重油 6.5\% の関税賦㭷㺼定めたもの)となつて あらわれたのである。たまたま, 輸出の好調を契機と した一般産業活動の旺盛, 電力用岑引取の活潑化, 船運 賃高騰による重油, 外国㞸競争力の弱化に文えられて,

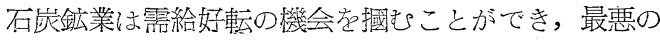
事態を漸く脱却するめとがついてきたといえよう。

2. 需 要 30 厢年国内岸需要は $43,465,000$ t で, 前年の 42,062,000 t に対し 1,403,000 t (3\%) の増加 となつた。しかし，これ在年と下半年とにわけて みると，様相好全く巽る。 


\begin{tabular}{rlrll} 
& \multicolumn{1}{c}{ 30年 } & \multicolumn{1}{c}{29 年 } & \multicolumn{1}{c}{ 比 } & 較 \\
1 6月 & 20,599 千 $t$ & 20,236 千 $t$ & +363 千 $t$ & $+1.8 \%$ \\
7 12月 & 22,866 & 21,826 & $+1,040$ & +4.8
\end{tabular}

前年に比し，下半年の堌加は上半年の増加の約 3 倍 に達した。このような需要増加が如何なる需要分野に よつてもたらされたか存第 1 表に示文。(資料の都合で 4〜7 月と 8〜11 月とにわける。)

\section{第 1 表 国內炭需要 30 年/ 29 年比較}

\begin{tabular}{|c|c|c|c|c|}
\hline 需要部閵 & \multicolumn{2}{|c|}{$4 \sim 7$ 月 } & \multicolumn{2}{|c|}{$8 \sim 11$ 月 } \\
\hline 公谷事業 & -218 千 $t$ & $91 \%$ & +830 千 $t$ & $131 \%$ \\
\hline 荤 & -178 & 90 & -104 & 94 \\
\hline 製 造工 業 & +666 & 110 & $+1,032$ & 114 \\
\hline そ の 他 & -248 & 86 & -6 & 100 \\
\hline 計 & +22 & 100 & $+1,752$ & 113 \\
\hline 産業別不明 & -297 & & -767 & \\
\hline A & -275 & 98 & +985 & 107 \\
\hline
\end{tabular}

上半年と下半年と様相が全く暴る点が一尿明瞭に出 ているがこれをもたらしたものは公益事業，次いで 製造工業である。公益事業は夏場渴水之電力需用旺盛 のためとによる電力用宸の増加が主因である。製造工 業は 4〜7 月でも対前年 $110 \%$ 光しているが，8〜11 月では $114 \%$ につている。化学工業, 紙パルプ, 緎 維，食料品など殆どあらゆる産業が上舁を示している が最も著しいのは高炉銑用崖の激増である。需要増加 への転㙨は渴水となつた 8 月であつたが，一般㱔造工 業部門殊に石㟶需要ウエイトの大きい鉄鐝，化学工羓 なとの伸びがきわめて堅実であることは今後の需要見 透し堂明るくするものである。

なお，石㟶需要の増加に影響している程度こそ的確 には掝み得ないが，(1外国炭輸大抑制政策と輸大先炭 価，海運賃值上りによる㫻入炭価の急上昇，2重油便 用抑制政策亡関税，油槽船運賃急騰による重油価格の 急激な值上り，この2つは看過できない。輸大岸価は 鉄銚向米孷年初 21 弗半程度であつたのが，年末には 27弗になつた。輸入炭要国内資源の乏しい炭種の最低 所要量に限定されているのであるが，㞸洒によつては ある程度国内炭に転換することは充分考えられる。ま た重油は 9 月以降最近までの間に站約 2,000 円の值上 りをしたと云う。石炭類転換が予想される訳である。

3. 生 産 30 年出㞸孔 $42,423,000 \mathrm{t}$ で, 前年よ り 294,000 t (0.7\%) の政減となつた。䨐要不振, 過 剰貯㞸が原因である。宸種等級別には第 2 表のとおり である。

\section{第 2 表 炭種等級别出炭構成比率}

$$
30 \text { 소 }
$$

29 年

原料炭 $17.2 \%$

$18.2 \%$
発生 炉 炭 3.7

4.0

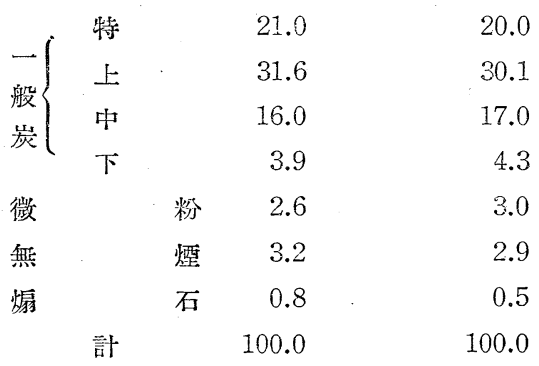

原料宸の減は前年の過剩生産を引!締めたためであ る。一般孷の特, 上級が増加しているのに対し, 中, 下級が減少てているのは, 品位の引上げと, 中小宸砸 の整理とによるものである。

しかし，生産の不振は後半年には著しく改善され た。年産心゙ースで年初 4,100万t が年末頃には 44〜 4,500万tに達した。これは主として中小炭砄の増産 によるもので，中小は整理の進行も早いとともに，復 與もきわめて早いことを実証した。矷数の変化は第 3 表のとおりでまたた全出㞸に対する中小の割合も29年 $31.7 \%, 30$ 年 6 月 $30.7 \% ， 12$ 月 $34.3 \%$ と激変した。 この間, 学務者数も大手の逐月減少に対し, 中小心 29 年末 92,000 人が 6 月末 85,000 人に減少したあと, 年末には 95,000 人に急增した。

$\begin{array}{cc}\text { 第 } 3 \text { 交 中小炭碳 数 } \\ 29 \text { 年末 } \\ 30 \text { 年 } 6 \text { 月末矿 } \\ 8 \text { 月末本 } & 564 \\ 10 \text { 月末 } & 593 \\ 12 \text { 月末 } & 650 \\ & 662\end{array}$

4. 貯 孷 年初 3,498,000t の密者䝪炭は, 需要 の不振にもかかわらず，生産の策めと荐砸の整理と によつて，夏場の堌加もわずかで， 7 月末 $3,722,000 t$ を最高として，あと需要の急伸により 12 月末 2,512 , 000 七に減少した。

\section{石炭に関する研究}

石炭の分析に関しては本会にも ISO 研究会が設け られ活潑に活動しているが，研究としては一般に迅速 簡便化に関するものが多い。まず水分について Gray 氏ら1はは濃硫酸と石炭を混じた場合の発熱量を測り全 水分等定量方方方法, Hubacek 氏ら2) $0.1 \mathrm{~N}, \mathrm{Na}_{2} \mathrm{~B}_{4}$ $\mathrm{O}_{7}$ 抢よび $\mathrm{NH}_{2} \mathrm{CH}_{2} \mathrm{COOH}$ の稀釈の程度により湿分 定量方方法, RomanyukE3) は $\mathrm{CaC}_{2}$ 崖加えて発 
生する $\mathrm{C}_{2} \mathrm{H}_{2}$ の圧力を以て湿分を定量する方法につい て述ヘた。これらはいら゙れも石炭以外の分野で利用さ れている方法であるが，石孷についても適用可能なこ

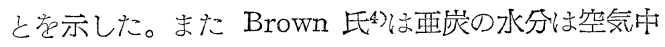
で乾燥定量すると酸素の添加により小さくでて，発熱 量も減少すると述へている。 Blach 氏5) は $800^{\circ} \mathrm{C} に$ 加熱した部分に徐々に䳝料学挴大して圧分学迅速正確 に測定する方法它提案し，Mikhailova 氏6) は $\mathrm{N}_{2}$ 気 流中でボートに大つた試料定同㥞にして揮発分を測定 する方法について述へた。

CおよびHの分析については，いわゆる Sheffield 高温法と呼ばれる方法が，乞の正榷度において従来の 方法に劣らず，かつ式速簡便で日常の作業に虎用し得 ることを，Mott 氏らう肪報告した。Sについては

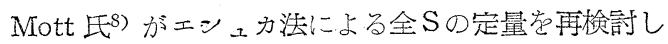
Zarauza 氏9）もまたェシュカ法の然焼時間を $\mathrm{O}_{2}$ を混 した気流中て短縮する方法を報告している。Belcher 氏ら10)はいわゆる Beet-Belcher 法と呼ばれるSおよ び Cl の定量方法を改良して，これを迅速化すること を述へた。Rodriguez Pire 氏ら11は Belcher 法打 よび Ellington-Adams の比色法で石炭中の $\mathrm{P}$ を定量 する方法を研究し，スペイン岸抢よびェークスでは後 星が迅速で誤差も少ないと述へている。Edgcombe氏

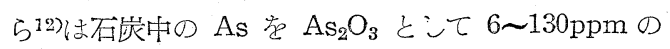
範围で正確に測定し得る方法を提䓩した。

石炭中の無機質の分析については Belcher 氏ら ${ }^{13)}$ が Na，Kの定量について述へているが，Anderson 氏 ら ${ }^{14)}$ はスペクトルを利用して同椂に Na，Kの定量を 行い一般に化学分标よりもやや少く出ると報告してい

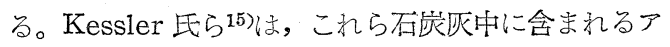
ルカリ金属のみならず $\mathrm{Ti}, \mathrm{Al}, \mathrm{Fe}$ および $\mathrm{Ca}$ のポー ラログラフを利用する分析方法を述へた。Edgcombe

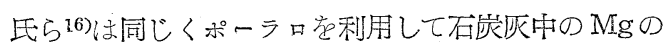
定量について検馀し， $5 \% \mathrm{MgO}$ までは重量法と一致し 15\% Ca までは Caの影響を認めなかつた。Bannerjee 氏ら ${ }^{17}$ )同じく石炭灭中の $\mathrm{Si}, \mathrm{Al}, \mathrm{Fe}, \mathrm{Ni}, \mathrm{Mn}$ ， $\mathrm{Mg}, \mathrm{Ca}, \mathrm{P}, \mathrm{Ge}, \mathrm{V}$ などの比色法による定量方法につい て述べ従来の方法と比較した。

発熱量に関しては新しい方法が見当らないが，工業 分析および元素分析結果からこれ在算出する方法は， 相変らず数多〈の提案がある18)。この䛧，石炭の分析 試噱に際して最も大切なサンプリングについては AS TM がその理論を検討したシンポジュウムを発行し た19)。

石宸組織学に関するものとしては 1953 年オランダ
国ゲレーンで開催された第 1 回国際石炭組織学会議の 報告が出された和。この内容はすでに知られているご とくであるが，1955 年にはえの第 2 回がベルギー国 リエージュで開催され多くの価值ある発表がなされ た。本邦に抢いても本協会にこの方面の研究会が設け られ，徙来石炭綜研で行なわれていたぜミナールをさ らに発展させることとなつた。研究としては丹野氏ら 21)が, 本邦石炭の組織学的特徵を説明し, また佐々木 氏組織成分の分離およびそのコークス工業への応用 について述へている。また McCartney 氏ら22)は従来 繁雑な手数を要する組織分析を自動化する方法を提案 した。

以上は可視光線の反射率を利用するものであるが， 近年赤外線吸収スペクトルが石炭の研究にも広く利用 されるに至つた。まず Brown 氏23》は各種石炭のビ下 リットについて赤外吸収スベクトルを撮り，78\%か ら次第にCが増加するとともにH結合を形成している -OH 基(多分 phenolic のもの) が減少し, 強粘結 崖であるC $89 \%$ ではほとんど消失する。さらにCが 堌加すると aliphatic の構造の減少と芳杳族縮合環構 造の発達が推定され，芳香族エーテルおよびキフン構 造抢よび芳香族性のHの存在が知られた。また 1160 $\sim 1300 \mathrm{~cm}^{-1}$ の広い吸収带は，Cの堌加とともに強さ が減少し, 芳香族エーテルの生成が考元られた。氏は さらにミ4)弱抢よび強粘結岸を乾溜して赤外吸収スペク トルを撮つたところ，400〜 $550^{\circ} \mathrm{C}$ て激しい变化が起 ることを知つた。すなわ゙ aliphatic CH おょび phenolic OH の著しい減少がみられた。そこで氏は 熱分解の機構として ailphatic group が C一C 結合 におきかえられるものと考光，また一OH 基の存在 が弱および強粘結炭の異りを示すものとし，さらに $800^{\circ} \mathrm{C}$ まで乾溜すれば試料が不透明となることから石 墨化が始まるものと推定した。氏ら ${ }^{25)}$ はまた石炭なア せチル化し溶剤で抽出し，えの抽出物の赤外スペクト ルを撮り H結合をしている phenolic $\mathrm{OH}$ の存在を磪 認し,また還元的なアセテル化の結果から hydroxyquinoid 構造の存在を推定した。また $\mathrm{LiCl}$ 学電解質 として傎用したポーラログラフにより dimethyloxydibenzanthrone, anthraquinone, hydroxyanthraquinone 類と類似した結果を得ている。Adams 氏ら 26)は空気になるへく触れないようにして採つた試料を 空気中打よび真空中で $200^{\circ} \mathrm{C}$ 以下に加熱して赤外ス ペクトルを撮つた。前者はH結合をしている一 $-\mathrm{C}=0$ の存在が知られ, また $\mathrm{C} 一 \mathrm{O}$ 扎よひ $\mathrm{O}-\mathrm{H} に$ 起因するとみられる 1150〜 $1300 \mathrm{~cm}^{-1}$ の吸収および 
acid dimer によると思われる $910 \mathrm{~cm}^{-1}$ の新しい昅 收がみられた。後者は石炭中に元来存在したOを有す る基の再配列に上ると思われる同㥞な变化をわずかに 示した。要するに空気の存在では $\mathrm{OH}$ 基の消費によ つて aromatic carboxylic acids が生成するものと 考えられる結果を得た。Berti 氏ら27) Sulcis 孷の 抽出物，ての溶剤分別物拈よびクロマトで分別したも のをしらべ,一 $-\mathrm{OH},=\mathrm{NH},-\mathrm{CO}$ 抢よび aromatic $\mathrm{CH}$ の存在を認めた。これらはさらに水素化すればより簡 単な構造となつた。Krevelen E(8) は各種石炭のビ下 リット，その酸化物および水素化物の赤外線による研 究を行つた。その結果C 91\%までは芳查族の発達がみ られ，それ以上のものでは石墨様の electronic absorption 坊現水れた。水素化物の小分子のものの内には メチル基存有する部分的に水素化されたフェナンスレ ン誘導体の存在を認めた。

X線趈析を利用するものとしては，Kessler 氏ら 99 がMikromet と称するチェッコ製の装置 (Cu-anticathode, $\mathrm{Be}$, 空, $40 \mathrm{kV}, 10 \mathrm{~mA}$ ) にて石炭抢よびューク スのX線廻析苍行い，セイロングラファイト，紧なぞ 之比較し $\mathrm{a}$ 韺面間隔就よ゙ $\mathrm{c}$ 朝方向の結晶子の広がり を算出した他，各種コークス類の研究を行い，その程 度は $\mathrm{H}$ の含有率に比例し，またその変化は 2 次元 random-distribution の法則に従うと述へた。

Hirsch 氏30) は石炭に対するX線の高抢よび低角拡 散を研究し，85〜94\% C の石炭では液体状の packing を示し, closed packed ミセルの存在は認められず, 異方性を有する割机目打よび $5,000 \AA$ 以上にも達する 広分分布の pore の存在が知ら机た。また無煙炭を除 いては石墨状構造よりはさしろ周辺に基を有する比較 的小さい芳香族縮合環をとの核構造として侾えるへき であるとした。Dryden 氏ら ${ }^{31)}$ はharasch の蹨焼 樊に関立る訫算式と Kreveien の ring condensation index から石炭の発熱量を訫算し, その結果 C 80〜 95\%の石崖では，その核構造単位の芳香族縮合環数 は 5〜20 と推定され，たとえばX線廻析により測定 した結果と一致すると報告し, さらに赤外スペクトル 抢よびX瑔䢙析の研究によれば aliphatic substitute をもつた fused aromatic ring からなると考光られ， また Nelson 氏らは洭青炭では核の大さは小さいとい つている。このことは H：Cの比が小さいことと矛 盾している。Dryden 氏はこの問題を調へて石炭の分 子構造のもつれを示し, 種々な方法で調製した分別物 について実験し，核をつないでいる○の役割を論じ だ2)。また同氏は過去 5 年間の石炭構造に対する新し
い着想を総括した33)。すなわち石炭抽出物の分子量は 500〜1000 て溶液は真の溶液てなく溶質である抽出物 は aggregate した形で存在し，抽出物はクロマトで 完全に分離し難く，各フラクンョンの赤外スペクトル は類似している。C 78〜9̉5\% の各石炭のビトリット の赤外スペクトルから芳香族縮合環構造 と aliphatic のHおよびO含有基とは石炭化度と密接な関係がある などの結論を示した。

吸着に関するものとしてはまず Khodot 氏ら ${ }^{34)}$ は石炭をX線廻析すれば石炭化の進むとともに結晶子 の発達がみられるにもかかわらず $\mathrm{CH}_{4}$ の吸着能はこ れと矛盾した結果を示方理由として，石炭の核構造の flexibility をあげている。すなわち各種の石崖の $\mathrm{CH}_{4}$ およびメタノールの吸着能を micropore とともに測 定したえころ ${ }^{35)}$, 揮発分35～40\%以下の石炭類は rigid absorbent とみられたが，40\% 以上では異状に高い 吸着能を示し flexible なものとみられた。Vaisman

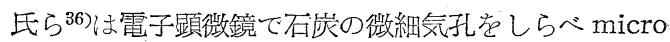

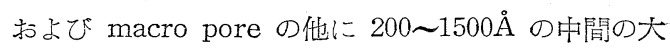
さの気孔が認められこれがいわゆるがス突出に関倸 があるとした。 Lamba 氏ら゙7)は $\mathrm{CH}_{4}$ の吸着能は石 炭の酸化により減少し，その傾向は表面加水化により 著しいことを示した。Kravchenko 氏387はガス突出に 際して石孷が破碎された破䂶菠 (crushing wave) が 炭層内に進行し，ガスおよび破砕炭はとれと逆の方向 に突出方るという考元からがス笑出の模様策示すに足 る式苍導いた。Ettinger 氏ら ${ }^{39}$ はガス吸着に際して 石炭の機械的強度泇下る間題について $\mathrm{CO}_{2}$ 吸収の場 合を実験した。Berkowitz 氏40) はカナダ炭の内部表 面積と湿潤熱を測定した。そその傾向は他国の石炭と同 樣で, 表面積として 15 300 $\mathrm{m}^{2} / \mathrm{g}$ 㠻得た。

電気およひ磁気的性質に関するものとしては，Kartashov E(1)が石炭粒子の静電荷電を測定し歴青炭な らば 0.1〜2mm の大さで磁力で分別するのに充分な 荷電をすると報告し，Krevelen 氏年2) は C 91\% 上 上の無湮炭の純ビトリニットの電気抵捥を測定した結 果, これらの石炭は本質的に半導体の性質を示し，え の抵抗はいわ的る aromatic area が大となれぱ小さ くなると報告している。同氏はまた石炭類の透電恒数 を測定し ${ }^{43)}$, 構造峃位当りの dipole momentは C 70\% の石炭で 0.5debye, C $87 \%$ で 0 となり,89\% 以上では電気伝導度の影響が顕著に現われると述へ た。劣氏らは熱膨脹俕数も測定し C $94 \%$ の石炭でそ の異方性が最大になることを示した。一般に石㞸は磁 性体といわれているが，これは通常えの測定が静磁場 
で行なわれるため大きな反磁性と小さな常磁性の差が 測定されているからである。ところが常磁性共鳴吸収 の方法では反磁性に比較して絶対值の小さい常磁性を も測定し得るが，常磁性の存在するためには不対電子 なとの特別な電子の存在が考えられる故, その構造, 性 質を考える上に重要な手脚りを与える。そこで近年こ の方面の研究が各地て開始された。英国のIngram氏ら 44)抢よびフランスの Ueberfeld 氏ら5)は石崖その他

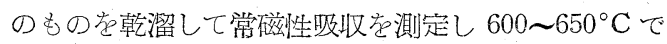
急激に0となることを見出した。このことは破れた 結合又は free radical の存在を示しその量は 1600 のC原子に対し 1 箇程度のものであることを示した。 宮下氏ら ${ }^{46}$ は石炭その他のものを測定した。その值は $\chi_{\mathrm{g} \text { para }} \times 10^{8}$ として天北目無宸の 0.3 から茅沼炭の 3.7 ，ホンゲイ無㖶孷の 9.0 に達している。

溶剂処理に関するものとしては，Pampuch 氏47は 各種の有機溶剤による石炭の膨脹度を測定した。若い 瀝青炭ではベンゼンで $8.1 \%$ ，ピリジンで $112.9 \%$ の 容積增大がみられ，一層炭化度の進んだもので最大の 膨潤率が示された。これに関し同氏は後者の方が多数 のH結合を有するものと考光ている。Dryden 氏48》は $\mathrm{CHCl}_{3}$ 可溶分と熱による軟化性との関䋆を論した。 Lakshmanan氏49) は南アスコット亜炭をぶンゼンェ

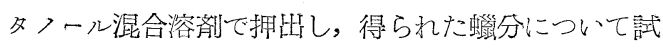
験した結果トシンタン㼃に比較してレジン質打よびア スファルト質が多いことを示した。Vekateswarlu氏

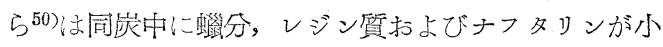
さな塊となつて天然に混在していることを発見した。 Dyakova 氏ら ${ }^{51}$ は humus および sapropelite 岸觉 各種の芳香族性溶剤て溶解しえの溶解能を測定し，そ の化学構造や極性添加物が活とんど影響しないことを 示した。

石炭の熱分解に関しては,川名氏ら5ッま天北目無炭， 夕張炭，ホングイ炭の熱分解により発生するガスを質 量分析計を孛使用して測定した。 $175^{\circ} \mathrm{C}$ 以下の低温で既 に $\mathrm{CO}$ および $\mathrm{CO}_{2}$ の発生がみられ, 夕張炭では温度 が上杽すると $\mathrm{C}_{3}$ 以上の高級パラフィンおよびオレフ インも発生するが,ささらに温度が高くなると $\mathrm{H}_{2}, \mathrm{CH}_{4}$, $\mathrm{C}_{2} \mathrm{H}_{4}$ などの低分子量のものが低くなることを示した。 本田氏ら ${ }^{53}$ 《㟶化時の岸の比重変化学測定した。天北 目無炭はセルローズ，グルコーズ抢よび石炭酸とホル マリンから造つたベークライト,また美唄, 高松, 夕 張, 鹿町炭などはm一クレン゙ールから製造したベーク ライト，無垔炭はカーボンブラックと類似した変化を 示すことから，もとの石炭の構造を推定した。King
氏(-5)怙よび Glass 氏55》は熱示差分析を行いビトリッ 下が各石炭を代表する性質を示し、 ニークス化性の判 定に役立つことを述へた。Rakovskii 氏56)，5i)はコー クス化の化学反応過程は多環芳香族環の生成と生長か らなると考え, aliphatic hydrocarbon 構造觉多くも つ石炭は弱いC-C 結合の解裂で粉状のコークス之な り, aromatic hydrocarbon 構造は強、C-C 結合 を有卞るため核縮合を起し $300^{\circ} \mathrm{C}$ 位で binaphtyl と なりつけでニークスとなる。また縮合反応は液相で容 易に起るからコークスの生成には最小限度の液相が必 要であると述へた。Sapozhnikov 氏ら ${ }^{58)}$ 执よびTitov 氏ら54)はアントラセンなどの中性泊，アビエチン酸な どの表面活性剤, $\mathrm{Fe}$ の酸化物, 硫酸塩など, $\mathrm{Al}, \mathrm{Zn}$ などの塩化物を石㟶に加えた場合の軟化性の変化を測 定し，酸化物は適当に加えた場合，縮合重合なとの反 応を起し膨脤性を押えコークスはよくなるが，加え過 ぎると石炭が酸化され粘結性が落ちることを示した。 また Fitzgerald氏60) は乾溜中の石炭のレオロジー的 性質を研究した。

石宸の酸化の内, 風化乃至は自然発火に関方るもの

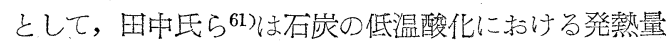
を測定し数十 $\mathrm{cal} / \mathrm{g}$ の值を得，その $50 \%$ はの結合， 他の $50 \%$ は湿潤爇その他からなること走知つた。 Chalupa 氏ら $\left.{ }^{69}\right)$ は, 酸化速度常数, 酸素消費量, 蓺 量淢, 全酸素消費量に対方る結合量の比加ら自然発火 の傾向を示方方法を提案し，Khrisanfova 氏 ${ }^{63)}$ は Permanganate No. で風化の程度を知る方法を述心

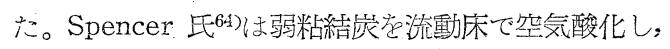
水素分と酸化生成物の比容積との間に值線関你がある ことを示した。

アルカリ溶液中て酸素て酸化する方法については,

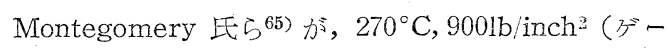
ジ圧) て酸化して得た coal acids 老酸性度の異りで 溶倣で分別し，また $1 \mathrm{~mm}$ の減圧で昇華して $13 \%$ の

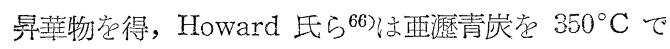
酸化した結果を報告し, 元素精覚から全体として石炭 に水が添加したことになると述べた。

樋口氏67》はまず亜宸の流動空気酸化の際生成する掩 発性物質の検荣定量を行い, $\mathrm{CO}_{2}, \mathrm{CO},>$ ォルムアル デセドはいずれも，その生成速度が2段階にわかれる ことを認め, 反応の後期はフミン酸の燃燒的反応によ るものと推定し, また醋酸の生成は可成り長いinduction period のあることを認めた。さららに氏ら ${ }^{68)}$ フミン酸と硝酸との反応について，その最大のものは 酸化, これにつぐものは加水分解であり, 前者は脂肪 
族鎖を切断する方向に進行する。またニトロフミン酸 生成時!副生する $\mathrm{HCN}$ および $\mathrm{NH}_{3}$ の定量により, これはフェフール基によるものと推定し，またその生 成量よりリグニンとの構造の類似性を示した。また二 トロフミン酸の示性式を示し $>\mathrm{C}=\mathrm{C}<$ の構造を有市 ることを $\mathrm{CH}_{2} \mathrm{~N}_{2}$ との反応で証明した。

Benning 氏 ${ }^{69}$ は $150 \sim 160^{\circ} \mathrm{C} ， 5$ 気圧で石炭の硝酸 酸化觉行、60～75\%の可溶分党得た。このものは benzen-carboxylic acids, aliphatic acids, ニトロ ミン酸などであつた。Bailey 氏ら 20 は石崖から再生 フミン酸を造りアルカリ性 $\mathrm{KMnO}_{4}$ で酸化して水溶性 の subhumic acid を造つた。Horton 氏i1) は同じ く種々の石炭をアルカリ性 $\mathrm{KMnO}_{4}$ て酸化して，石 炎化の過程を追跡した。フミン酸については, Kukharenko 氏ら ${ }^{i 2)} は$ 各種の石炭のフミン酸のアルカリ 溶液の粘度走測定し泥孷フミン酸の化学構造は石炭の それよりも枝を多くもつた非整合な形をしていると述 べた。Tishchenko 氏ら゙3は褐崖を $\mathrm{N}_{2}$ 抢よび空気中 でアルカリで抽出し得たフミン酸を比較した。後者は メチル化で定量される一 りこれれはフミン酸中の cumarine ring の 2,3 の 位置の一つの $\mathrm{CO}_{2} \mathrm{H}$ が空気と接触して phenolic $\mathrm{O}$ H におきかえられたものと考えた。Kukharenko 氏 らª)は液安中で金属 $\mathrm{Na}$ とフミン酸の区広定しらべ た。民応生成物は石炭化の進んたももの程 $\mathrm{C}, \mathrm{H}$ が多く 分子量は 200〜273 であつた。

最近石炭の塩素化の交献が再び現われ出したが， Alekseva氏75) もウクライナ褐炭を塩素化し70\%の塩 素化炭を得た。このものは低温で通常の有機溶㓮抢よ びアルカリ類に可溶で，沸点水抢よび dichlorethane にも溶けた。

水素化については Pelipetz 氏 ${ }^{6)}$ が Rock Spring 孷の高圧水素化を行い，水素の初圧とべンゼン不溶分 との間には一次反応の関係があることを示し，また Lahiri 氏ら ${ }^{\pi 7}$ は Assam 炭を $\mathrm{SnS} 80 \%+\mathrm{NH}_{4} \mathrm{Cl} 20 \%$ 存触媒として高圧水素化を行い最高の液化率は触媒 $2 \% ， 24 \mathrm{hr}$ の反応時間て得られたと報告した。

石炭中に含まれる高価な無機質については $\mathrm{Ge}$ が その代表であつた。従つてその調查は数多く行なわれ た。たと党ば岡氏ら苂)は北宫城, 南岩手地区の亜岸中に 含まれる $\mathrm{Ge}$ の含有率をしらべたが一般に上下磐に近 い処に多く, 最大のものは無水無灰べースで $357 \mathrm{ppm}$ 含まれていた。Hawley 氏(99は Nova Scotia 炭の Ge 含有率をしらべ同椂の結果を得ているが, 組織成分と 含有率との間に一定の関䌽がないと述へている点は従
来の説と異つている。この方面のニューフェースは原 子力時代にふさわしいUである。Denson 氏ら ッキー山地带の石炭, 亜炭, 頁岩中のU含有率を調査 し，その含有率は $0.2 \sim 0.05 \%$ で上部にある火成岩に

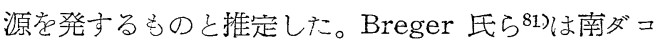
夕亜炭を比重て撰別しUの含有率が $0.12 \%$ から 0.31 \%に上昇することから，有機質と結合していると考 え，別に $\mathrm{HCl}$ で浸出した結果から有機U化合物また は錯湓として存在すると推定し，Uが业炭中に入つた 機構を述べた。氏らはさらに敫石㟶を $800^{\circ} \mathrm{C}$ まで乾 溜してもUの損失はないことを確めた。この他 Med-

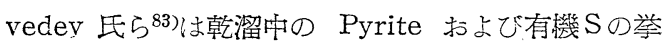
動を述へまた Endell 氏(-84)は Oscillation Viscometer で石炭化の高温に拈ける粘度を測定した。こ れらの試験に関するものとして，Ellman 氏ら ${ }^{55)} の$ Hardgrove 法で測定した业炭の粉砕性の測定がある。 一般に気乾試料の index は 37〜81 て，水分が中間 程度で 26〜58 に下り，さらに乾燥するとまた上昇し ている。

全般的な問題としてはZ Zabramnyi 氏\$6)は低温乾溜 生成物で石炭を分類することを提唱しており,Trotter 氏87゙は 4,000 呎に抢よぶボーリングで 24 層 220 箇の コアから石炭化と地質條件との関係をしらべたH Hück 氏88)は石炭化の反応を論しいわ切る人造石炭は石炭生 成に対して demonstrative なものでないと述べた。 鈴木氏ら ${ }^{89}$ は各種の石岸の化学的および物理的試験か ら石炭の構造抢よびュークス化を論じた。

\section{交献}

1) V.R. Gray, et al., Chemistry \& Industry. 126.

2) Jos. Hubáček, et al., Paliva, 33, 209 (1953); C. A., 7831.

3) L. I. Romanyuk, Trudy Izvest. Teploenerget, No. 7, 115 (1952); C. A., 2952.

4) G.M. Brown, Australian J. Appl. Sci., 6, 365, 376.

5) S. Btach, Coment-Wapno-Gips, 11, (20), 235 ; C. A., 2950.

6) E.P. Mikhailova, Izvest. Akad. Nauk Kazakh S. S. R., Ser. Energet., No. 7, 59 (1954); $\boldsymbol{C}$. A., 10605.

7) R. A. Mott, et al., Fuel, 34, 169 ; L. J. Edgecombe, ibid., 34, 185.

8) R. A. Mott, et al., ibid., 34, 78, 87. 
9) J. A. Corrales Zarauza, Inst. nacl. carbon.

Bol. inform., 3, No. 18, 13 (1954); O. A., 6579.

10) R. Belcher, et al., Fiel, 34, 219.

11) L. Rodriguez Pire, et al., Inst. nacl, carbon Bol. inform., No. 20, 84; O. A., 11983. Г6575

12) L.J. Ebgecombe, et al., Analyst, 80, 155. O.A.,

13) R. Belcher, et al., Anal. Ohim. Acta, 11, 120 (1954); O. A. 6576.

14) C.H. Anderson, et al., Anal. Ohem., 20, 1369 (1954).

15) F. M. Kessler, Pr'ace Usiava pro Vyzkum a Vyuzili Paliv. No. 1 9, 117 ; O. A., 2950.

16) L. J. Edgcombe, et al., Analyst, 80, 236; $O$. A., 7221.

17) N.N. Bannerjee, et al., Fruel, 34, S71 (April 1955).

18) B. K. Mazumdar, J. Sci. Ind. Research (India), 13B, 857 (1954), その他

19) Symposium on Coal sampling, ASTM, Spec. Tech. Publ., No. 162.

20) Proc. Internatl. Comm. Coal Petro., No. 1 (1954).

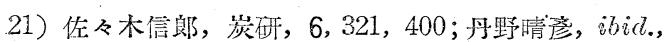
6,362 .

22) J. T. McCartney, et al., Anal. Chem., 27, 13 20.

23) J. K. Brown, J. Ohcm. Soc., 744.

24) J. K. Brown, ibid., 752.

25) J. K. Brown, et al., Ohemistry \& Industry, 1118.

26) W. N. Adams, et al., Fuel, 34, 383.

27) V. Berti, et al., Riv. combustibili, 9, 5; $O$. A., 13620.

28) D. W. van Krevelen, et al., Fuel, 34, 50.

29) F. M. Kessler, et al., Paliva, 34, 97 (1954); O. A., 9256.

30) P. B. Hirsch, Proc. Roy. Soc. (London), A2 26, 143 (1954).

31) I. G. C. Dryden, et al., Fuel, 34, S 36 (April 1955).

32) I. G. C. Dryden, ibid., S 29.

33) I. G. C. Dryden, Brenn. Ohem., 36, 80.

34) V. V. Khodot, et al., Doklady Akad. Nauk,, S.S. S. R., 88, 309 (1953); O. A. 9902.

35) V. V. Khodot, et al., ibid.; O. A., 11983.
36) B. A. Vaisman, et al., ibid., 97, 1031 (1954) O. A., 13619.

37) E. G. Lamba, et al., Izvest. Akad. Nauk., S. S. S. R. Otdel. Tekn. Naik, 1955, No. 4, $110 ;$ O. A., 15209.

38) V. S. Kravchenko, ibid., 101 (1955); O. A., $50,1289$.

38) I. L. Ettinger, et al., Doklady Alad. Nauk., S. S. S. R., 99, 1057 (1954); O. A. 13619.

40) N. Bekowitz, Oan. J.T'echnol., 33, 169; O.A. 12813.

41) G. K. Kartashov, Izvest, Akad. Navk, S. S. S. R., Otdel. Tekn. Nauk, No. 7, 21 (1954); O. A. 5808 .

42) D. W. van Krevelen, et al., Frel, 34, 213.

43) D. W. van Krevelen, et al., ibid, 339, 345.

44) D. J. Ingram, et al., Nature, 174, 797.

45) J. Ueberfeld, et al.,ibidd, 174, 614.

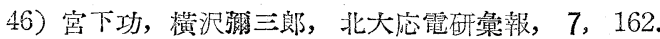

47) R. Pampuch, Przeglad, Gówny 11, 77; C. A. 11259.

48) I. G. C. Dryden, Friel, 34, 363.

49) Sm. Lakshmann, Fuel, 34, 219.

50) D. Vekateswarlu, et al., J. Indian. Onem. Soc., Ind \& News Ed., 17, 112 (1954); C. A., 5813.

51).M. K. D'yakova, et al., J. Applied Ohem. (U. S. S. R.), 28, $55 ;$ C. A., 9901.

52) 川名善男他, 日化誌, 76, 1228.

53）本田英昌他，ibid，76，151.

54) L. H. King, Econ. Geol., 50, 22.

55) H. D. Glass, F wel, 34, 253.

56) V. E. Rakovskii, Izvest. Akad. Nauk Belorwss, S. S. R., 1953, No. 3, 91; O. A., 2702.

57) V. E. Rakovskii, Referat. Zhur., Khim 1954, No. 26116 ; O. A., 5810.

58) L. M. Sapozhnikov, et al., Trudy Inst. Goryich Iskopaemylk Alad. Nawk., S. S. S. R., 3, 52 (1954); O. A., 6574.

59) N. G. Titov, et al., Izuest, Akad. Nauk., S. S. S. R., Otdel. Tekh. Nark., 1954, No. 9, 114; C. A. 7218.

60) D. Fitzgerald, Natwre, 175, 515.

61）田中正男，山崎殕彥，日鉣誌，71，633.

62) V. Chalupa, et al., Uhli, 5, 310; O. A. 50, 
1289.

63) A. I. Khrisanfova, Izvest. Akad. Nauk., S. S. S. R., Otdel. Tekh. Naik, 1116 (1949); O. A. 7221 .

64) D. H. T. Spencer, Fivel, 34, 131.

65) R.S. Montegomery, ẹt al., Ind. Eng. Ohem., 47, 1274 .

66) H. C. Howard, et al., ibid., 47, 1589.

67）樋口耕三, 澁谷裕, 本誌 $34,286$.

68) 桶口耕三, 露口亭夫, 浅川一雄, 本誌, 34, 645.

69) A. Benning, Brenn. Chem., 36, 38.

70) A. E. W. Bailey, et al., Fuel, 34, 37.

71) L. Horton, Fuel, 34, S 34 (April 1955).

72) T. A. Kukharenko, et al., Doklady, Akad, Narit., S. S. S. R., 98, 1007 (1954); O. A., 11 984.

73) V. Tishchenko, et al., Ser. Khim. Nank., No. 11, 250 (1952) ; C. A., 15210.

74) T. A. Kukharenko, et al., Doklady Alad. Nauk., S. S. S. R., 86, 601 (1952); C. A., 50, 2949.

75) V. A. Alekseeva, Ukiain Khim. Zhir., 20, 319 (1954); O. A., 50, 2146.

76) M. G. Pelipetz, Ind. Eng. Ohem., 47, 2101. 77) A. Lahiri, J. Sci. Ind. Research (India), 14B, 284.

78）洋好良, 菅野卓治, 鮎沢三郎, 芳賀一夫, 東北大 選研刍報, 11, No. 1, 17 (1955).

79) J. E. Hawley, Econ. Geol., 50, 517.

80) N. M. Denson, et al., U. S. Atomic Energy Comm., TEM-341A (1952); C. A. 10606.

81) I. A. Breger, et al., Econ. Geol., 50, 206.

82) I. A. Breger, et al., Science, 120, 310 (1954); C. A. 589 .

83) K. P. Medvedev, et al., Izvest, Akad. Nauk. S. S. S. R., Otdel. Tekh. Nauk., 1955, No. 8, 134 ; C. A., 50, 2146.

84) J. Endell, Silicate ind., 20, 405; O. A., 50, 2952.

85) R.C. Ellmann, et al., U. S. Bưr. Mines, Rep. Invest., 5167.

86) C. T. Zabramnyi, Izvest. Akad. Nauk. Uz-bek S. S. R., 1953, No. 4, 74; O. A., 10610.

87) F. M. Trotter, Pioc. Yorkshire Geol. Soc., 29, 267 (1954); O. A., 6573.

88) G. Hück, et al, Brenn. Chem., 36, 1.

89）鈴木好一他, 本誌, $34,286$.

\section{コークスエ業の罍勢}

\section{I 製鉄用関係}

30 年の鉄鋼生産は世界的景気好転の影響を受けて 3 月より急上景し好況を続けた。粗銅生産量は約 940 万 $\mathrm{t}$, 前年比 $22 \%$ 增, 銑鉄生座量は約 520 万 $\mathrm{t}($ 高炬銑 500 万 $\mathrm{t}$ ), 前年比 $13 \%$ 増である。これに伴つて ークス 生産も増加したが高炉のコークス比は事前処理合理化 の進捗に伴い前年に引続き低下，全国平均 0.71 とな つて下止りの状態にある。

30 年にはコークス昵の新設はなかつた。富土釜石の 4 号炉が 4 月改築成り操業を開始したほかコークスの 増産は主として稼動炉の生産率増加によつた。生産率 の増加は炭化時間の短統によるものであるが若化時間 15 時間という急速作業も行われた。富士広畑では特 にフリュー温度を上げる事など炉温管理の徹底によつ てこの目的を達した。

原料宸では米炭が米国内産業の稼㗢率上昇々翰出増 加, 海上運賃急勝のため岸価昂滕し cif 20 弗を突破 するに至つた。これを反映して米宸の使用率は減少し 内地弱粘結崖の便用率が堌加した。開欒宸, 樺太炭の 輸大が増加したがその量はなお全輸入炭量の 1 割に達 しない。

米炭の低灰分と内地宸の山元洗炭普及により 30 年 には各コークス炉とも附属洗炭機の運転をみないよう になつた。

\section{II 製鉄用以外}

昭和 30 年は米穀の豊作ならびに世界的経済好況の 波に乘るわが国経済專情の著しい好転, 諸生産活動の 活発化によりコークスの荷動きも活況を带び，その赹 等は期を追つて旺になつた。

コークスの生産，荷渡し実績は第 4 表および第 5 表 に示すとおりであつて，需給の推移概況を述心ると次 のごとくである。

すなわち，荷渡しは総括的にみるに 29 年に比し， 1〜3 月はや队減であつたものが，4〜6 月は 10\%， 7〜9 月は 15\%，10〜12 月は 30\% の増加，年間で は $14 \%$ の増であつた。さらに用途別内容をみると， 石灭窒素，カーバイド间コークスの需要は年を通じ旺 盛で, 対 29 年夫々 $25 \%, 60 \%$ の出荷増となつた。 これは 29 年末頃の甚しい渴水による電力不足から， 需要者が所要コークスの購大を手控え, 手持ストック の減少范来していたが，2月初旬からの暖気で山元の 
（通信產業省大臣官房調查統計部調）

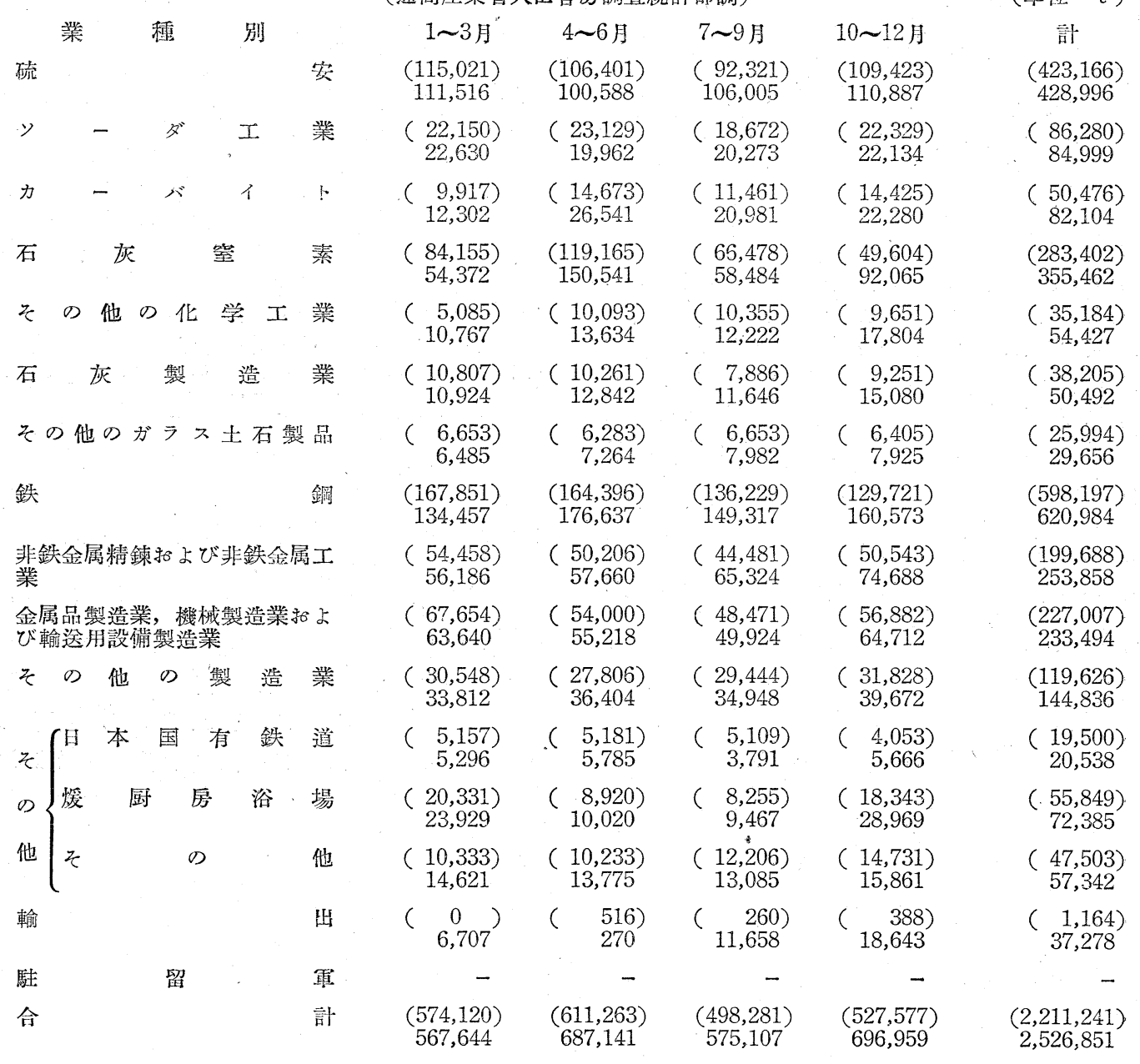

\begin{tabular}{|c|c|c|c|c|c|c|c|c|c|c|c|c|}
\hline & & & \multicolumn{2}{|c|}{ ガス事業 } & \multicolumn{2}{|c|}{ コークス專業 } & 化 & 学 & 製 & 鉄 & 合 & 計 \\
\hline $1 \frown$ & 3 & 月 & $\begin{array}{c}\text { 生 產 } \\
(605,508) \\
622,118\end{array}$ & $\begin{array}{c}\text { 出 獄 } \\
(374,100) \\
385,941\end{array}$ & $\begin{array}{c}\text { 生 產 } \\
(212,316) \\
193,047\end{array}$ & $\begin{array}{c}\text { 出 荷 } \\
(209,002) \\
100,401\end{array}$ & $\begin{array}{c}\text { 生 產 } \\
(30,918) \\
27,966\end{array}$ & $\begin{array}{c}\text { 出 渮 } \\
(2,124) \\
1,592\end{array}$ & $\begin{array}{c}\text { 生 產 } \\
(971,751) \\
866,847\end{array}$ & $\begin{array}{c}\text { 出 荷 } \\
(25,325) \\
12,778\end{array}$ & $\begin{array}{c}\text { 生 泩 } \\
(1,820,493) \\
1,709,978\end{array}$ & $\begin{array}{c}\text { 出 荷 } \\
(620,551) \\
590,712\end{array}$ \\
\hline 4 & 6 & 月 & $\begin{array}{c}(541,555) \\
582,342\end{array}$ & $\begin{array}{c}(417,225) \\
479,327\end{array}$ & $\begin{array}{c}(201,438) \\
205,034\end{array}$ & $\begin{array}{c}(191,359) \\
198,008\end{array}$ & $\begin{array}{c}(31,628) \\
31,327\end{array}$ & $\begin{array}{c}(2,168) \\
1,561\end{array}$ & $\begin{array}{c}(935,680) \\
944,368\end{array}$ & $\begin{array}{c}(38,148) \\
37,638\end{array}$ & $\begin{array}{c}(1,710,301) \\
1,763,071\end{array}$ & $\begin{array}{c}(648,900) \\
716,534\end{array}$ \\
\hline $7 \sim$ & 9 & $\pi$ & $\begin{array}{c}(504,265) \\
527,578\end{array}$ & $\begin{array}{c}(330,644) \\
372,038\end{array}$ & $\begin{array}{c}(179,535) \\
203,158\end{array}$ & $\begin{array}{c}(164,969) \\
106,763\end{array}$ & $\begin{array}{c}(32,033) \\
32,060\end{array}$ & $\begin{array}{l}(1,781) \\
1,716\end{array}$ & $\begin{array}{c}(823,627) \\
966,208\end{array}$ & $\begin{array}{c}(30,659) \\
32,015\end{array}$ & $\begin{array}{c}(1,539,460) \\
1,729,004\end{array}$ & $\begin{array}{c}(528,053) \\
592,592\end{array}$ \\
\hline $0 \sim$ & & 月 & $\begin{array}{c}(552,567) \\
641,188\end{array}$ & $\begin{array}{c}(382,408) \\
465,780\end{array}$ & $\begin{array}{c}(186,716) \\
211,703\end{array}$ & $\begin{array}{c}(183,603) \\
220,364\end{array}$ & $\begin{array}{c}(30,154) \\
30,132\end{array}$ & $\begin{array}{c}(1,728) \\
1,485\end{array}$ & $\begin{array}{l}(755,262) \\
1,004,084\end{array}$ & $\begin{array}{c}(24,259) \\
34,284\end{array}$ & $\begin{array}{c}(1,524,699) \\
1,887,107\end{array}$ & $\begin{array}{c}(591,998) \\
721,923\end{array}$ \\
\hline & & & $\begin{array}{c}(2,203,895) \\
2,373,226\end{array}$ & $\begin{array}{c}(1,504,377) \\
1,703,086\end{array}$ & $\begin{array}{c}(780,005) \\
812,942\end{array}$ & $\begin{array}{c}(748,933) \\
795,536\end{array}$ & $\begin{array}{c}(124,733) \\
121,485\end{array}$ & $\begin{array}{c}(7,801) \\
6,354\end{array}$ & $\begin{array}{c}(3,480,320) \\
3,781,507\end{array}$ & $\begin{array}{c}(128,391) \\
116,725\end{array}$ & $\begin{array}{c}(6,594,953) \\
7,089,160\end{array}$ & $\begin{array}{c}(2,389,502) \\
2,621,701\end{array}$ \\
\hline
\end{tabular}

(碏侾) カッコ內数字沼和 29 年度実績であつて 30 年度と対比参考上附記した。 
雪融けが例年よりりも早く訪れ，豊水期が早まつたので 急にコークスの需用を㬇び豊水状態が 6 月迄引続いた のと, 未曾有の米穀豊作で次年に䜤えての化学肥料の 要求增となり,また有機合成化学の進展に伴う需要も 増加してきたためである。ただし，硫安向については 年度内はやや増を示した程度であつた。

鋳物，精鍊用需要は鉄鋼その他金属の世界的好況か ら次第に増加し，非鉄金属精鉬抢よび非鉄金属工業に おいては $25 \%$ の荷渡し増をみた。

東南アジアなどに対する輸出量も著しい増加であつ た。また 29 年の需要減退に処し，新規需要面の開拓 に力を大れたュークス生産販売業者の努力は一般暖房, ボイラー, 製茶, タバコ乾燥用向実需增となつてあら はれ暖厨房用のごときは $40 \%$ 增であつた。

30 年は上のごとき需要堌の諸因が重つて 29 年の過 剩ストックを一掃したばかりでなく年末頃には出荷が 需要に追付かなくなる程の様変りを呈するに至つた が，一つには予てがス事業者がコークス不況対策とし て, ガス拡充 5 カ年計画に基く供給がス量の増加を賄 うのに, ガス生産原料として生産コークスを使用し可 販コークス量を相当抑えるガス生産方式を強化したこ と，或はオイルガス生産椂式を採用したことも原因し ている。

鋳物，石灰品素用コークス原料の一部として年々輸 入してきた高品位, 特殊原料崖はフレイトの著しい昂 騰にもかかわらず必要量を輸大した。

\section{コークスに関する研究}

乾溜またはコークス化に関する基礎的な研究：

石炭に関する研究の項と一部重複するものがあると思 われるので重要なもののみにとどめる。

川名氏ら1)は質量分析計によつて低温乾溜ガスの分 析を行つた結果を報告し，Dryden 氏ら ${ }^{2)}$ は粘結炭は 軟化温度附近まで加蓺したときの $\mathrm{CHCl}_{3}$ 可溶成分の 量が大きいという特徴を持つことを報告し，この成分 の消長と軟化現象とが密接な関䋆をもつと述べ, Brown 氏(3) は粘結㟶を乾溜して赤外スペクトルの变化を 調へた結果から熱分解機構に考察を加え Glass 氏4)は 粘結炭の示差熱分析を行うとともにこの曲線がコーク ス用炭としての適否をよく示し, 石㟶分類法およびキ 一ゼラプラストメータの結果とよく関連をもつと述へ ている。乾溜の反応熱については別に millard 氏5),6) がコークス炉の装入炭温度の経時変化の実測值と熱流 れの式から求められる計算值とを比較した結果から $700^{\circ} \mathrm{C}$ 以下では吸熱, 以上では発熱的であることを導
き出し数種の石炭について反応熱を求めている。瞦脹 圧については城本氏らすが休止前の実空を利用し異常 な膨脹圧をもつポカホンタス岸の単味コークス化抢よ び配合試験を行い，押詰り現象を起す理由と配合の安 全限界とを明らかにし，Gayle 氏ら`は膨脹圧は炉内 ガスの内部圧の測定によつてふつうのコークス炉でも 測定しうると述へた。Khudokormova 氏9) は乾溜炉 内の発生ガスのうちどれ位が高温の炉壁側をとおり， どれ位が低温の未乾溜崖層をと抢るかを実験室レトル トおよびュークス炉について測定している。

コークスの亀裂については, 吉田氏7),10)が発生の原 因とそれを支配する因子に考察を加元，Soulé 氏111は 角裂発生の機構を明らかにし，城本氏らては実験䇪製 コークスの亀裂特性をもとにして加熱條件の影響を寒 弿試験によつて確認した。

ニークスおよび乾溜法に関するもの：

まず綜説的なものでは Reerink 氏 ${ }^{12)} は$ ばイッコー クス委員会 No. 106 報告として, 原料岸の性状試験, コークスの製造，使用などに関する最新の知見につい て報告し，英国に抢いても強粘結炭の代りに次第に他 種の石炭を用いる必要に迫られつつあるが, Parker 氏ら ${ }^{13)}$ はこの場合に必要な洗㟶, 酸化, 粒度調整, 配 合, 成型などの予備处理法とこれらに関係ある重要因 子に検討を加え，城本氏(4)も高炉用コークス製造研究 上の 2,3 の問題を検討した。

つぎに製造法に関するものとしては，粘結性の劣る 石崖から主として冾金用コークスを製造しょうとする 方法として配合法, Sovaco 法,フェロコークス法, 2 段乾溜法などの研究が多い。すなわち配合に関しては, 福永氏 ${ }^{15)}$ が配合における相性の良否は主として愹融性 の合致または不一致に基因するとの結果を得, 相浦 氏16)は高炉用コークスを製造するために弱粘結炭に配 合するコーライト，粉コークスなどの補強材について

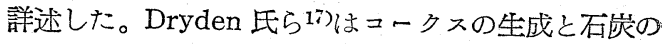
配合について多数の交献をあげて綜説を行つた。 Kröger 氏ら ${ }^{18)}$ はガス崖とコークス用宸を種々の割合で配 合して多方面の試験を行い。ドラム強度, コークスの 構造（気孔径，壁の厚さ，比重など）は配合率に対し て直線的に変化しないことを報告し, Kennedy 氏 ${ }^{19}$ はガス㟶の乾溜の際に濠州褐㟶煉炭を配合して使用す る実験を矜み, 最も膨脹性の強いがス炭の場合でも 25 \%以上の褐崖を配合できず，またガスの収量増すが 熱量は低下すると報告している。石炭ではないが石灰 の配合については西尾氏20)の報告がある。 組織成分の選択破研選別によつて弱粘結岸から冶金 
用コークスを製造する Sovaco 法 (Burstlein 法)は 脚光を浴びて数年を経だが, Burstlein 氏21)はこの方 法の原理と 4.年間の工業的試験結果からみた技術的問 題について述へ，ローレン，ザールなどの石炭に限ら ず大抵の石炭に適用できる，装炭方法の如何にかかわ らず用いうる, 経済的である, 補助プラントを設けた のみでよく既存設備に手を加えずに実施できる，との 結論を出している。この方法はドイワでも研究，実施 が行われて拈り，Abramski 氏22)がその大要之有用性 を述へるとともにこの方法における装入宸粒度分布の 重要性を指摘し粒度試験による粒度指数算出法を提示 しているほか, Jenkner 氏23)がこの方法を採用した Mannesmann 工場の設 備と試験結果について報告し ている。

低シャフト炉により含鉄ブリケットニークスを用い る製銑とともに晋からのいわゆるフェロコークスの製 造および使用などに関する研究が多いのも近年の傾问 である。Russel 氏24)，Whitstone 氏25)はこれらに ついて綜説を試み，缶焼および試験炬による製造試験 から鉄鉣石の添加によつて装炭密度, 乾溜時間, ニー クスのサイズ, 反応性, 強度などを増大させ, コーク スの歩留りを低下さけること，畭溜中に還元された鉄 が湿式消火，屋外放置によつて一部再酸化されること その他乾溜生成がスの組成などについて述へ，門倉氏 26)もこれらの綜説を行つた。Barking 氏ら2て)はガス 炭と粉鉱の混合物を乾溜してフェロコークスを製造し コークスその他の収量, 原料がコークス品質に及ぼす 影響などを眀らかにし, 特に粉炭の粒度, 粉鉱の添加 量, 混合の均一性に注意が要ると述へ, 小規模の炉で も高炉でも十分に使用できることを実験で確めた。 Liggett 氏28)は高炉にフェロコークスを使用した結果 についてのへ，少量の場合は效果的に用いてコークス 比が下るが，10\% 以上用いる場合はフェロコークス のサイジングが必要であること, 鉄鉱石はコークス強 度が上昇する範国内で用いるへきであると説いてい る。Linde 氏29)もフェロコークスによる熔鉱炉の操業 試験について, 操業條件, 操業結果, フェロコークス の使用による銑鉄中の Si の増加, ニークス消費量な ・どについて報告している。

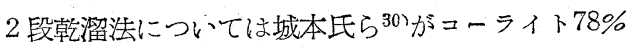
に弱粘結炭 $12 \%$ ，ピッチ $10 \%$ を混して成型後榦溜 する方法を研究し，ブリケットの強度は十分であつた が、ニークスの強度が弱く，反応性が高すぎることを 報告した。また 2 段畭溜ではないが，成型コークスの 製造については Broadbent 氏ら ${ }^{31}$ が亜歴青炭から強
度の高い成型コークス bricoke を作るには予め最低 $800^{\circ} \mathrm{C}$ に乾溜して収縮を十分に行わせてから成型し $500^{\circ} \mathrm{C}$ まて乾溜するのがよいと報告し, Clifton 氏 ${ }^{22)}$ も同様の実験を行い，成型前に最低 $700 \sim 800^{\circ} \mathrm{C}$ に乾 溜する必要があることを認め,粘結倣としてのタール， ピッチなどの優劣を比較した。

以上は主に冶金用コークスを対象としたものである が英国では大気浄化委員会のいわゆる Beaver リ亦ー トが出て以来，家庭用無煙然料の増産が問題とならて いるが(3),34)，その一つとして粘結性の弱いものの塊崖 を直立レトルトで高温乾溜して作つたものが Grancoleの名で出された35)。強粘結炭を使わないですむ上 に粘結性の低い石炭の方が反応性のよいニークスにな るという点でも好都合とされている。

つぎに乾溜法に関するものとしては，同しく英国の 連続式直立レトルトの乾溜速度を增大させる新しい弑 みについて昨年の本項で紹介したが，その後 Hod-

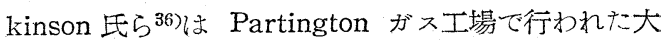
規模の試験結果についてのへており，レトルトの長い 方の巾 10in 当り 1 日 1.8〜1.9 の速度で乾溜ができ, レトルト当りのガス得熱が 35〜40\% 増大するといわ れ，ボタン指数 7 までの石炭で操業がうまく行くと考 えられている。Grant 氏らろ゙もこの方法について論じ ている。

流動乾溜法の研究は相変らず盛で，その一部はすで に実用化に大りつつある。ALCOA が趡設した $31 \mathrm{t} / \mathrm{hr}$ 処理のParry 法の炉は昨年に引続いて Parry 氏 ${ }^{38)}$ によつて報告が出されており，資源技術試験所の純内 熱式中規模プラントの試験結果を照井氏が発表してい る。このほか Schuylkill 発電所では1日 $2 \mathrm{t}$ の連続 式流動乾溜炉が設けられたが39)，ここでは粉炭を予備 酸化装置中で流動法で酸化したのち，軽く脱揮発分を 行つた半成コークスと急激に混合して乾燥し 700〜80 $0^{\circ} \mathrm{F}$ に熱して粘結性を失わしめ,ついで乾溜塔に大れ て 800 $1200^{\circ} \mathrm{F}$ で乾溜する方法がとられている。印 度でもShrikhande Eら ${ }^{40}$ )が直径 $2 \mathrm{in}$. の炉㾟用いて 試験しているが，これは 1 回の容量が $21 b$ のバッチ式 で流動化には尒熱した窒素を用いている。フランスで は Peytavy Eら ${ }^{41}$ 肪内熱式で $500 〜 600^{\circ} \mathrm{C}$ て乾溜を 行つて比重 0.3〜 0.5g/cc のものを得ているほか石炭 公社の中央試験所でも行われている。

最近のコークスの品質管理および炉の操業管理の進 歩は目ざましいものがあるが，特に当協会コークス部 会の第 21 回特別会ではこの問題に大きな重点が注が れ, 西尾, 坪内, 中原氏その他から各社のコークス师 
の操業管理について報告49が行われたほか，別に西尾 氏き，松沢氏门もこれについて報告している。

コークスの脱硫については城本氏ら ${ }^{43}$ が三池炭，大 島炭などの硫黄の大部分が有機性のもので除去しにく いこと, 乾溜の際の硫黄の挙動などを確めたのち, 融 点 $1000^{\circ} \mathrm{C}$ 以下の八ロゲン化合物を少量混じて缶燒 を行い， $\mathrm{NaF} ， \mathrm{NH}_{4} \mathrm{~F}, \mathrm{AlCl}_{3}$ などが脱硫效果がすぐ

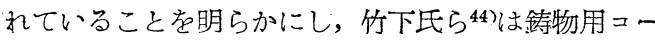
クスに炭酸ソーダ，青酸ソーダなどを加えて熔銑を行 い,コークス硫黄の銑鉄への侵大防止を試み，ルツボ では有効と認められたがキュポラでは效果がうすいと の結果を得た。Samec 氏 ${ }^{45)}$ はコークスの脱硫は水素 雾囲気下で乾溜を行うよりもコークスを水素気流中で 消火する方が効果があると述へ， Draycott 氏 ${ }^{46)}$ は洗 炭打よび雗溜後，コークスに湿り空気を作用させるこ とはいづれも効果がうすく，乾溜中に石炭がスを添加 するが油がスと水蒸気存時々吹き込むのが最もよく， 前者ではコークスの硫黄が 4.7\% から 3.1\%にに低下し， 後者ではさらに0.79\%に低下した。

コークスの性質に関するもの：

コークスの性質をその構造に遡つて関連づけたもの に井上氏らの研究がある。同氏47748)らはコークス塊を 長さに沿って数個に分けて物理的性質の変化を測定し た結果からコークスの基本体の集合の仕方にようて その構造ひいては性質が決まると述心，この構造の基 本体の性質は温度などの乾溜條件によつてきまり，恐 らく原料石炭の配合の美には関係しないことを報告し た。井上氏゚らはコークス塊の電気抵抗を測定しこ れとコークスの構造，マイクロストレングスとの関係 を述へ，また石炭を常温から $3000^{\circ} \mathrm{C}$ まて熱处理した 之きのX線的構造の变化を明らかにした49)。

松山氏50)は半成コークスのスチーミング反応によつ て起る表面組織打よび宸素の微結晶の変化を顕微鏡, X線回折により調へている。つぎにコークスの諸性状 に及ほす製造條件の影響を調べたものをみると，松村 氏゙がコークス粒度の均一化をはかるため，粒度に及 ほす乾溜條件，運搬処理などの影響を報告し，中原氏4? が 2 年閒の作業データを解折して強度抢よび粒度の変 動要因とこれらの要因からく当限界を明らかにした。 また次田氏らゔ流動特性の異る 4 種の道内宸につい て加熱率, 装入炭粒度, 水分などの乾溜條件を变えて コークスの粒度, 強度，見掛比重，歩留りなどに対す る影響を明らかにした。

Gayle 氏ら ${ }^{51)}$ は Tuscaloosa の試験师を用いてフリ ニ温度がコークスの物理的性質に更㳆す影響を検討し
Kalinowski 氏ら ${ }^{52)}$ はスタンピングして装入炭の蔏密 度を 36\% 増加することによりコークスのスタビリテ イ抢よび八ードネスがそれどれ平均 12％，37\% 方 増したと報告, Turchenko 氏ら ${ }^{53)}$ は乾溜終了時の炉 内コークスの状態 (readiness) は電気抵抗 (オーム) の測定によつて乾溜過剩 $(0 \sim 0.7)$, 正常 ( 5.0), 不 十分( 100), 開始状態 (100〜) の 4 段階にわけるこ とができ，この測定がコークスの製造と炬の能力の増 大に役立つと報告している。

反応性については Bastick 氏ら $\left.{ }^{54}\right)$ が種々のコークス の内部表面積と反応性との関係を求め，またュークス 類のガス化速度は活とんど同じォーダであること，水 蒸気の場合よりも $\mathrm{CO}_{2}$ の場合の方が表面が容易に展 開されると報告, Guerin 氏ら ${ }^{55) は コ ー ク ス を ~} 1000^{\circ} \mathrm{C}$ で水蒸気気流と反応させてガス化速度が炭素消費量 10〜60\% の間では一定であるがこれより初期の值は 啇当でないことを確証した。ほかに Dahme 氏56)の報 告がある。また水分については Tietze 氏 コークスの水分分布などについて，福原氏ら ${ }^{58}$ が治金 用コークスの粒度分布について，永田氏i゙が強度特性 の表示法についてそれでれ発表している。

Mackowsky 氏(59)が高炉用ュークスの性質の新しい 評価方法については強度の均質性をみるによい Graf 指数，組織の均質性を調べる顕微鏡試験打よび反応性 なぞの試験法を報告しており，Taylor 氏60) は高炉お よびキュポラに㧍けるコークスの役割とコークスの具 備すべき性状などについて多数の交献をあげて綜説し た。カーバイド用ョークスについては，コークス技術 留談会でその具備すべき性状なぞについて詳細な討論 が行われている61。

なお分析および試験方法などに関するものとして， Mott 氏ら ${ }^{62)}$ は分析用のコークス試料を調製する場合 に生ずる種々の誤差について実験, 検討を加え, これ を低減させる方法を述へ，窝津氏らうは C と Hの迅速 分析法范研究しこれまでに行つた $\mathrm{S}$ 燃焼法，N七ミ ミクロ法をこれに組み合せれば1時間以内で元素分析 を行いうると報告し，Düwel 氏63) はハンブルグガス 工場が乾溜用炭に対して日常平行的に行つている数種 のコークス化性試験方法とそれらの特徽を報告し, Flickirger 氏ら ${ }^{64)}$ は BM-AGA 式実験室レトルトを 用いた乾溜試験の副産物収率はプラントの場合と密接 な関倸があつてこれによつて回収の良否を評価するこ とができると述べている。

コークスの使用に関するもの：

昨年 12 月からの東京都の煤煙防止條例の実施に関 
連してビルの暖房用ボイラのコークス焚きに関心が寄 せられ，関係の各氏から試験, 研究の結果が報告され た ${ }^{65)}$ 。

高炬における使用に関連しだものでは, 堀氏でが種 々の粒度のコークス充填層の通気度を試験して, 圧降 下に影響を及ほす寸諸因子を検討した。

和田氏66)は $1,100 \mathrm{t}$ 高炑で $1,400 \mathrm{t}$ を出銑し，しかも 灰分 12.5〜13.6\%もあるコークスを用いたにもかか わらずニークス比を 1,300〜1,4001bに低下させ得た ことを報告し，これがコークスを含む原材料の粒度調 整に負うところが大きいことを報告し，久田氏ら畐もも コークス粒度その他の装入物粒度が高炉操業に大きな 影響をもつことを報告, 高木氏ら ${ }^{687}$ 《水分の変動およ び粉の発生率からみると高炉用コークスの平坛粒度は 60〜68mm が最適と認められ, 他方高炉の操業実績 の面から求めた数字も凡そこれ位になると報告してい る。Rogers 氏69)は 4 つの高炉の 4 年間に亘る操業結 果を統訂的に解析し, 各種の高炉操業要因抢よびニー クス要因が出銑速度、コークス比などに及活す影響を 明らかにし、コークスの性状の影響は比較的少いこと を明らかにした。

Bardin 氏ら ${ }^{70)}$ は高炉に抢けるコークスの燃焼状態 を高速度写真などによつて研究し，羽口前でニークス の循環運動が起きていることを認め, ニークス屬とし てのみでなくブラストは晒垂された状態でも燃焼が行 われていることを明らかにした。Baldwin 氏71)はコー クスによる酸化鉄の還元機構を研究し，ほとんど例外 なく、CO 分子が酸化鉄を還元し，生じた $\mathrm{CO}_{2}$ がコー クスと反応して CO を生ずる過程をとることを示し， これらの結果の高炉の研究への応用について検討し た。

Jungbluth 氏72)は B.Osann の発案になる高炉用コ 一クス評価法がキュポラ操業についても適用できるこ とを示唆し, 愹解速度, 衝風量, キュポラの燃焼状態 およびュークスの反応性の重要性を指摘した。

設備に関するもの：

林氏7),73》は東京瓦斯千住工場のコークス炉プラント 建設に際して採用した種々の新しい試み，すなわう科 量用歪ア゙ージをつけた門型製炭車, 衝擊粉研機, ビュ ーラコンベアその他を紹介し，稻原氏は米国のコーク ス炉を調查見学した結果について述へた。諸外国の設 備については, Simon-Carves 炉 216 門, 1 日 5,200 $\mathrm{t}$ の能力をもつ印度タタ製鉄の Jamshedpur 工場の 新しい第 4 バッテリ゙4)のほか多数のものが関係誌上に 紹介された。

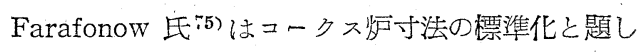
て米, 英, 独, ソなと各国のコークス忓の寸法の発展 の歴実と現状の調查結果を示して将来の傾向に触れ， Masson 氏i6)は炉の大型化には炉堂の高さを増すべき であるとして炬室を高くした場合に起りうる諸問題を 検討し，Dougill 氏市はがス製造プラントとしてみた 場合のコークス炉に批判を加え, Sansam 氏は副産物 回収プラントの最近の発展について述へた。

炉の修復，寿命などに関するものも割に多く発表さ れ西尾氏78)は本邦各所で一たん休止後再開して稼動中 の全コークス炉について休止, 再開の方法, その後の稼: 動状況を詳細に調査して批判点加元, 稻原氏ではコー クス充填の蒸し込み徐冷によるコークス炉の休止作業: とその結果について報告した。Haffner 氏799は英国の 水平，直立各レトルトおよびコークス炉などの耐火物 の寿命を調査し, 要修理に至るまでの稼動日数, 損傷の 原因抢よびその個所などを詳細に述へ，Drake氏 ${ }^{80) も ~}$ 実際面からのコークス炉の修理と再建について述べた。

\section{交献}

1）川名善男他, 日化誌。

2) I. G. C. Dryden et al., Fuel, 34, 363 (1955).

3) J. K. Brown, J. Ohem. Soc., 1955, 752 ; C. A., 49, 9255 (1955).

4) H. D. Glass, Fiel, 34, 253 (1955).

5) D. J. Millard, J. Inst. Friel, 28, 345 (1955);

6) D. J. Millard, Nature, 174, 1099 (1954).

7) 第20回コークス特別会請演 $(1955,4$ 月); 要旨コー クス・サーキュラ, 4, No. 2, 9 (1955).

8) J. B. Gayle et al., Am. Gas. Assoc. Proc., 36, 628, 1954 ; C. A., 49, 13625 (1955).

9) P. Khudokormova, Stahl, 15, 295 (1955); $O$. A., 49, 16398 (1955).

10）吉田雄次, 石炭評諭, 6, 671 (1955).

11) J. L. Soulé, Fuel, 34, 68 (1955).

12) W. Reerink, Stahl w. Eisen, 75, 1099 (1954).

13) A. Parker et al., Gas World, 142, 838 (1955).

14) 城博, 九州鉿山学会誌, 23, 28 (1955).

15）福永登, 富㐊鉄技報, 4, 413 (1955).

16）相浦光典，製鉄研焭，No. 209, 804 (1954).

17) I. G. C. Dryden, Ooke \& Gas, 17, 272 (1955)。

18) C. Kröger et al., Brenn., 35, 142 (1955).

19) G. L. Kennedy, Fruel, 34, 321 (1955).

20) 西尾醇, コークス(広烟), 1955, No. 6, 19.

21) E. Burstlein, Chal. et Industr. 353, 351 (195

4); 354, 14 (1955); Fuel Absts. 17, 30 (1955).

22) C. Abramski, Glückanf, 91, 714(1955).

23) A. Jenkner, Glückauf, Beiheft, 1955 年 8 月, 202.

24). C. C. Russel, Gas World, 141, 1616 (1955).

25) P. Whitstone, 同上 141, 1685 (1955). 
26) 門倉参次，コークスサーキュラ，4，No. 3, 19 (1 955).

27) H. Barking et al., Stahl u. Eisen, 75, 386 (19 55).

28) R. R. Liggett, Gas World, 141, Coking Sect. 40 (1955).

29) H. Linde, Stahl $u$. Eisen 75, 691 (1955).

30）城博，鉄之銅，41，929 (1955).

.31) R. Broadbent et al., J., Inst. Fuel, 28, 3 (19 $55)$.

32) V. E. Clifton, I. Inst. Fuel, 28, 255 (1955).

33) Colve \& Gas, 17, 466 (1955).

34) C. A. Deas, Gas $W_{o^{\prime}} l d, 142,1675$ (1955).

35) Colie \& Gas, 17, 471 (1955).

36) W. Hodkinson et al., Gas $W_{0 r} l d, 141,1414$ (1955).

37) A. F. Grant et al., Gas J. 282, 369; 453 (195 5).

38) V. F. Parry, U. S. Bur, Mines, Rept. Invest. 5123, 27 pp. (1955).

39) Chem. Eng. News, 33, 2376 (1954).

40) K. Y. Schrikhande, J. Sir. Ind. Research (India), 13B, 634 (1954).

41) A.A. Peytavy et al., Bull. Soc. Chim. France. 1955, 453; O. A., 49, 8583 (1955).

42）第21回コークス特別会講演

43）城博他，製鉄研究，No. $211 ， 889$ (1955).

44）竹下健次郎他, 本誌, 34, 629 (1955).

45) M. Samec, Bull. Sci. Oonseil Acad. RPF Yowgoslavie 2, 46 (1955); O. A., 49, 12818 (19 55).

46) A. Draycott, Chem. Ind. \& Eng., 3, No. 7, 17 (1954); O. A., 49, 4968 (1955).

47) 并上勝也他, Fuel, 34, 356 (1955).

48) 北上勝也他, F'uel, 34, 471 (1955).

49) 石炭化学に関する許演会 (1955 年 11 月)

50) 松山英太郎，本誌，34，553 (1955).

51). J. B. Gayle et al., U. S. Buir. Mines, Rept. Invest. 5126, 16 pp. (1955).

52) B. Kalinowski et al., Hutnik, 22, 247 (1955);

C. A., 49, 15212 (1955).

53) Turchenko

54) Bastick.

55) H: Guérin, Compt. rend., 239, 376 (1954); $\boldsymbol{C}$. A., 49, 12818 (1955).

56) A. Dahme, Brenn. Chem., 36, 193 (1955).

57) W. Tietze, Glückauf , 91, 1094 (1955).

58）稻原敏雄他，鋼管技報，22号，19（1954）

59) M. Th. Mackowsky, Glückauf, Beiheft, 1955 年 8 月, 221 (1955).

60) J. Taylor, Iron \& Steel (1955).

61）第14回コークス技術想談会; コークス・サーキュ э, 4, No. 4, 1 (1955).

62) R. A. Mott, Gas World, 141, Coking, Sect., 31 (1955).
63) G. Düwel, GWF', (Gas) 96, 625 (1955).

64) C. H. Flckinger et al., U. S. Bir. Mines, T'ech. Pap. 726, 51 (1955); C. A., 49, 12817 (1 955).

65）第15回コークス技術愁談会; コークス・サーキュ 5, 4, No. 4, 5 (1955).

66) 利田亀吉, Blast Fur. Steel. Pl., 43, 401 (1955).

67）久出清明他，鉄之鋼，41，484 (1955).

68）高木直他，富士鉄技報，4，165（1955）.

69) W. T. Rogers, Blast Fir. Steel Pl. 43, 627 (1955).

70) I. P. Bardin et al., Izvest. Akad. Nauk S. S. S. R., Otdel. Tehh. Nauk, 1955, No. 1, 80 (1955); C. A., 49, 12813 (1955).

71) B. G. Baldwin, J. Iron St. Inst.

72) V. Jungbluth, GWF (Gas), 96, 78 (1955).

73) 林盛四郎, 本誌, 34, (1955).

74) Ooke \& Gas, 17, 127, 167 (1955).

75) W. Farfonow, Gas World, 142, Coking Sect 54 (1955).

76) H. J. von Masson, Gas World, 141, Coking Sect. 121 (1955).

77) G. Dougill, Gas World, 141, 948 (1955).

78) 西尾醇, 富士鉄技報, 4, 285 (1955).

79) A. E. Haffner, Gas World, 142, Coking Sect, 67 (1955).

80) J. V. Drake, Gas World, 141, Coking Sect, 38 (1955).

\section{炭素に関する研究}

状態に関するもの：H.P. Boehm氏ら hedral form の石墨の存在, 安定性, hexagonal form との変態の機作などについて論じた。都竹氏2),3) らは C. black を $2500^{\circ} \mathrm{C}$ に加熱して得た石墨単結 晶に，六方ピラミッド型の積層構造を，電子顕微鏡に よつて認め，反詨向きの 2 つのラセン転位に始まる複 次構造のラセン的成長危見出し, 電子線趣折によつて (ool) 平面をラセン平面とする 2 次元石墨網目構造で あることを推論し，Frank の不完全結晶の成長理論 をあてはめた。R. Lilijeblad 氏4)は石墨とがィャモン ドとの転移点は $3000^{\circ} \mathrm{K}$ 附近で最大の $62,000 \mathrm{~atm}$ と なり，以後減少するとしたが，R. Bermann 氏ら5)は $12000^{\circ} \mathrm{K}$ 以上を直線で外插した式， $\mathrm{P}(\mathrm{atm})=70.00+$ $27 \mathrm{~T}\left({ }^{\circ} \mathrm{K}\right)$ を提出し，さらに6) Lilijeblad 氏の值より も妥当であることを強調した。 F. P. B und 氏らうけ $3000^{\circ} \mathrm{K}, 100,000 \mathrm{kgm} / \mathrm{cm}^{2}$ の條件で $1 \mathrm{~mm}$ のダイヤ モンドの人造に成功したと報じている。P.Goldfinger 氏8)は $\mathrm{C}_{1}, \mathrm{C}_{2}, \mathrm{C}_{3}, \mathrm{C}_{5}$ などの気体分子について，㞸素の 気化に関玄る熱力学的問題を論じ, R.T. Thorn氏ら 9)は石墨の気化速度を測定した。 M. Hoch 氏ら ${ }^{10)}$ 
石墨， $\mathrm{TaC}, \mathrm{WC}$ などについて炭素の気化熱を測定し て，いずれについても $\Delta H_{0}{ }^{0}=170 \mathrm{kcal} / \mathrm{mol}$ であると L，W. A. Chupk 氏ら”は質量分析計で，石墨から の $\mathrm{C}_{1}, \mathrm{C}_{2}, \mathrm{C}_{3}$ の蒸気圧を測定し $\tau$, 気化熱として, そ

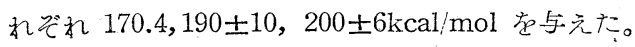

電気抢よび磁気的性質に関するもの: D.F.Johnston 氏12》石墨の電子構造について, 正ネルギ分布を決定 する正確な式を与え, さらに13) Hall 効果の温度係数 を $100 \sim 140^{\circ} \mathrm{K}$ の間で測定し,これから electron trap の数を計算する方法を導いた。T. G. Berlincourt 氏ら ${ }^{14)}$ は液体Heの温度でごく強い磁場を用い， Hall 効果, 磁气抵抗, 磁気俰数などの振動現象を測 定し, 石墨の電子带構造について考察を行つた。E. Taft 氏ら ${ }^{15}$ )は石墨から放出される光電子のエネルギ 分布について論じ，P. T. Narasimhan 氏 ${ }^{16)}$ はダイ ヤモンドの誘電率の温度係数灰測定した。井口氏ら は炭素類の電気伝導度について総説を行つている。

J. E. Hove 氏 ${ }^{181}$ は石墨の磁気係数に対する理論的 な洘察を行い， G. R. Gennig 氏ら ${ }^{199}$ は石墨ブロム系 について磁気係数を測定し, 石墨の带構造からの電子

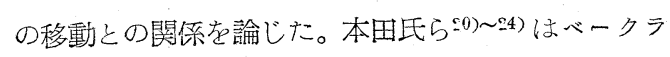
イト類拉よひ石炭類の炭化物について，2000 ${ }^{\circ} \mathrm{C}$ まで の炭化, 石墨化過程における比重, 磁気倸数, 磁気係 数の温度係数, 電気抵抗などを測定して炭化, 石墨化 過程におおる構造変化を推論した。

T. E. Bennet 氏(ら5) は glucose, sugars, cellulose, anthracene, glycerin およびその他の有機物, 石宸などの炭化物について，20〜290 $\mathrm{K}$ て常磁性共鳴 吸収老定量的に測定し, 遊離基濃度は炭化温度 $550^{\circ} \mathrm{C}$ まで増加して極大となり，1/2000 C. atoms 程度とな るが，以後急激に減少して零となることを示し，遊離 基は炭素縮合環におおる遊離結合に伴うもので，縮合 環が動き易くなり，石墨平面が生し始める $600^{\circ} \mathrm{C}$ 附 近て遊離結合が消失するためであると説明している。 宫下氏ら (6) は硫酸銅の結晶の小片を内部尺度として, 石炭類抢よび bakelite, glucose, cellulose, vinyl acetate, violanthrone など崖化物について常磁性 共鳴吸収の強さを測定した。D. J. E. Ingram 氏ら 2i)は sucrose をがス管中に封じて $400^{\circ} \mathrm{C}$ に焼き，空 気にさらした場合の拈離基濃度の減少速度を測定し, 遊離基濃度の半減期は 5 秒であると述べ, $\mathrm{A}$ または $\mathrm{N}_{2}$ 中ではこのような現象が起らぬので, 酸素の作用によ るものと推論している。

X線备折に関するもの：Y. Baskin 氏ら ${ }^{28)}$ は石墨の

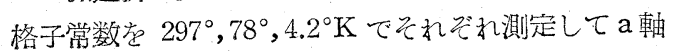

方向の距離は変化しないが，C軸方向では温度変化に より不可逆的に変化すること克見出し，L.Alexander 氏29`は数種の C. Black について面間距離を測定 した。F. M. Kessler 氏ら 30 ねは石油コークスおよび擵 青炭コークスの烺焼において, X線廻折抢上び物理, 化学的性質と $\mathrm{H}_{2}$ 含量の変化が関係することを論し， さらに3!) $2000^{\circ} \mathrm{C}$ 以上の石墨化過程における石畨化度 について検討した。G. R. Housk 氏ら ${ }^{32)}$ は C. black の石墨化において初期段階の結晶構造について考察し た。P. L. Walker Jr. 氏 ${ }^{33)} ら は$ 種々の炭素について 宸酸ガスとの反応の進行に伴つての格子常数抢よび結 晶子の平均直径の変化を測定した。

熱的性質に関するもの, W. De. Sonbo 氏 の比熱を測定した。

吸着に関するもの：H. L. McDermot 氏ら ${ }^{35}$ 《よ土工 黒鉛における $\mathrm{H}_{2}, \mathrm{O}_{2}, \mathrm{~A}$ などの吸着を行い，毛管の存 在や結晶内部の膨潤との関係について論じ：S. Rosa

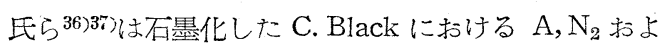
び Kr の吸着を低温で行い，吸着分子を気体論的に取 报つて, それぞれの臨界温度, 吸着熱などを計算し た。C.A. Amberg 氏ら ${ }^{38)}$ は石墨化した C. Blackに ついて Kr の吸着を行い，吸着過程を二段階に永け て論した。O. Gubeli 氏ら ${ }^{39}$ 《活性炭に执いて Rn の 吸着を放射能によつて測定し，Wm. V. Loebenstein

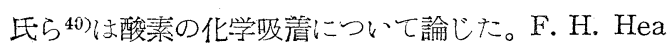
ley 氏ら ${ }^{41)}$ は Graphon の表面酸化物の量と水蒸気吸 着抢よび湿涯熱との関係を検討した。M. M. Duhinin 氏ら ${ }^{49}$ は C. Black, 活性炭に抢いて，水蒸気の吸着 と表面積の関倸から理論式を導いた。 M. H. Polley 氏ら43》は C. black に抢ける Butane および Butene の吸着とゴム補強材としての性質とについて詭いた。 R. M. Barrer 氏ら ${ }^{44)}$ は炭素に抢けるAの吸着および 毛管中その拡散について論した。D. H. Everett 氏45) は木炭における心゙ンゼンの吸着について熱力学的な考 察を加え，B. R. Puri 氏ら (6) は種々の炎の水による 湿涯熱を測定した。R.S. Hansen 氏らでは Graphon, Spheron なぞの無孔性炭素について $\mathrm{MeOH}$ おょび $\mathrm{EtOH}$ からの Octane, Decane, Do-decane などの 吸着を行い, 表面酸素 Complex の影響について論し た。A. Blackburn 氏ら48》は木炭について水溶液から の $\mathrm{HCOOH}, \mathrm{CH}_{3} \mathrm{COOH}, \mathrm{CH}_{3} \cdot \mathrm{CH}_{2} \cdot \mathrm{COOH}, n-\mathrm{C}_{3} \mathrm{H}_{7}$ $\mathrm{COOH}$ なぞの吸着を行い，Traube の法則を説明し た。

毛管分布に関するもの：西村氏ら の毛管分布，内部比表面積，有孔率などの測定および 
水蒸気， ゙゙ンゼンの吸着を行い，これらの性質の間の 関䌽や賦活における変化について論したた。P. L. Wal-

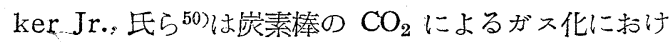
る比較的大きな毛管 $(350 \sim 130,000 \overline{\mathrm{A}})$ の分布变化につ いて論じ，M. M. Duhinin 氏51)は活性崖の毛管構造 の研究方法について述べている。

反沈性に関するもの：E. R. Gilland 氏ら 52)は $\mathrm{CH}_{4}$ の熱分解によつて触媒上に生じ炭素と $\mathrm{H}_{2}$, 水蒸気, $\mathrm{O}_{2}$ 抢上び $\mathrm{CO}_{2}$ との反応について述心，岡田氏ら ${ }^{52)}$ は $620^{\circ} \mathrm{C}$ て酸化した炭素の重量減少に伴う, 見掛比 重, 有孔率, ヤング率, 曲け強度拉よび電気抵抗なぞ の変化を測定した。E. E. Peterson 氏 ${ }^{54) 566}$ 流 900 $\sim 1300^{\circ} \mathrm{C}$ に扎いて人工黒鉛と $\mathrm{CO}_{2}$ との反応速度と 表面積との関係について論じ，毛管中の拡散速度が律 速的であると推論した。P. L. Walker Jr. 氏ら ${ }^{5 i}$ ) は $900^{\circ} \sim 1300^{\circ} \mathrm{C}$ で炭素棒のガス化の速度と, 灰の分析 水素含量, X線廻折, 比重, 有孔率, 表面積放よび氷 素の拡散係数を測定してここれらの関係について論じ た。C.W. Zielke 氏ら ${ }^{58}$ は炭化物のガス化について 速度論的な解明を行い, H.M. Frey 氏(5) ( $\mathrm{HCl}, \mathrm{HF}$, $\mathrm{HBr}, \mathrm{HI}, \mathrm{H}_{2} \mathrm{SO}_{4}, \mathrm{H}_{3} \mathrm{PO}_{4}$ などの酸による木炭の前処理 の酸化に対する効果についいて論じた。

その他：山内氏(0) 61) はアセチレンブラックの種々 の物理化学性を測定し, 乾電池用として適したものの 性質について論した。北川氏ら ${ }^{69}$ は活性岸の脱色力と 政酸一重クロム酸カリによる湿式酸化性との関係につ いて論じた。鈴木氏63》は澱粉炭に $\mathrm{ZnCl}_{2}$ および $\mathrm{K}_{2} \mathrm{C}$ $\mathrm{O}_{3}$ を含ませて $650^{\circ} \sim 950^{\circ} \mathrm{C}$ に加熱し，賦活過程に ついて論じ, 吉沢氏ら ${ }^{64)}$ はリグニンに $\mathrm{ZnCl}_{2}, \mathrm{CaCl}_{2}$, $\mathrm{H}_{3} \mathrm{PO}_{4}$ 抢よび $\mathrm{NaOH}$ などを含ませて乾溜し，乾溜過 程および賦活作用について考察を行つた。

\section{交献}

1) H. P. Boehm \& U. Hofmann., Z. anorg. $u$. allsem. Ohem., 278, 58 77, (1955).

2) 都竹, 莎田, J. Phys. Soc. Japan, 10, 81〜2 (1955).

3) 都竹, Tokai Technol. J., 16, 1 (1955).

4) R. Lilijeblad, Arkiv. för Kemi, 8, 423 (1955).

5) R. Bermann \& F. E. Simmons, Z. Electrochem., 59, 333 (1955).

6) R. Bermann \& J. Thewlis, Nctise, 176, No. 4487, 834 36 (1955).

7) F. P. Bundy, F. T. Hall, H. M. Strong \& R. H. Wentorf, Nature, 176, 51 (1955).

8) P. Goldfinger, Mem. Soc. roy. sci. Liege, 15, 378 85 (1955).

9) R. J. Thorn \& G. H. Winslow, J. Cheri. Phys.
23, 1369 (1955).

10) M. Hoch, P. E. Blackburn, D. P. Dinglady \& H. L. Johnston, J. Phys. Chem., 59, 97 9 (1955).

11) Wm. A. Chupka \& M. G. Inghram, J. Phys. Chem., 59, 100 4 (1955).

12) D. F. Johnston, Proc. Roy. Soc., A227, 349 58 (1955).

13) D. F. Johnston, ibid., 359 67.

14) T. G. Berlincourt \& M. C. Steele, Phys. Rev. 98, 956 (1955).

15) T. Taft \& L. Apker, Phys. Rev., 99, 1831 2 (1955).

16）非口，遠井，炭素，5，7 (1955).

17) P. T. Narasimhan, Proc. Phys. Soc, 68B, 315 〜18 (1955).

18) J. E. Hove, Phys. Rev., 100, 645 9 (1955).

19) G. R. Hennig \& J. D. McClelland., J. Ohem. Phys., 23, 1431 5 (1955).

20）本田, 大內, 広瀨, 日化誌, 76, 148 51 (1955).

21）本田, 大内, 広瀨, ibid.. 151 4.

22) 本田, 大內, ibid. 154 8.

23) 本田, 大內, 鋀田, ibid.,,361 4.

23) 本田. 大內, 豊田, ibid., 364 72.

25) J. E. Bennet, D. H. E. Ingram \& J. G. Tapley., J. Chem. Phys., 23, 215 (1955).

26）宮下, 橫沢, 応電彙報, 7, 3 (1955).

27) D. J. E. Ingram \& J. G. Rapley., Ohem. \& Ind., 1955, 568 9.

28) Y. Baskin \& L. Meyer., Phys. Rev., 100, 544 (1955).

29) L. Alexander \& S. R. Carin., J. Chem. Phys., 23, 594 5 (1955).

30) F. M. Kesoler \& V. Vecerikova., Paliva., 34, 154 62 (1954).

31) F. M. Kessler \& V. Vecerikova, ibid, 188 93.

32) C. R. Houska \& B. E. Warren., J. Appl. Phys., 25, 1503 9 (1954).

33) P. L. Walker Jr., \& F. Rusinko Jr., Fuel. 34, 822 28 (1955).

34) W. De. Sonbo, J. A. C. S., 77, 4713 (1955).

35) H. L. McDermot \& J. C. Arnell., Oan. J. Chem., 33, 913 22 (1955).

36) S. Ross \& W. Winkler., J. Colloid Sci., 19, 319 29 (1955).

37) S. Ross \& W. Winkler., ibid., 330 7. 38) C. H. Amberg, W. B. Spencer \& R. A. Beeve., Can. J. Chem., 33, 305 13 (1955).

38) C. H. Amberg., W. B. Spencer \& R. A. Beeve., Oan. J. Chem. 33, 305 13 (1955).

39) O. Gubeli \& M. Stori., Helv. Chim. Acta,37, 2224 30 (1954).

40) Wm. V. Loebenstein \& V. R. Deitz., J. Phys. Ohem., 59. 481 7 (1955).

41) F. H. Healey, Young-Fang Yu \& J. J. Che- 
ssich., J. Phys. Chem., 59, 399 402 (1955).

42) M. M. Dubinin, E. D. Zaverina \& V. V. Serpinskii., J. Chem. Soc., 1955, 1760 6.

43) M. H. Polley, W. D. Schaeffer \& W. R. Smith. Oan. J.Ohem., 33, 314 19 (1955).

44) R. M. Barrer \& E. Strachan., Proc. Roy. Soc. (London)., A231. 52 74 (1955).

45) D. E. Everett \& W. I. Whitton., Proc. Roy. Soc. (London) A230, 91 110 (1955).

46) B. R. Puri, P. C. Gupta \& M. L. Lakhanpal., J. Indian. Chem. Soc., 31, 435 8 (1954).

47) R. S. Hausen \& R. D. Hausen., J. Phys. Ohem. 59, 496 8 (1955).

48) A. Blackburn \& J. J. Kipling., J. Chem. Soc., 1955, 1493 7.

49) 西村, 斎藤, 森田, 工化誌, 58, 5 7 (1955).

50) P. L. Walker Jr., F. Rusinko Jr. \& E. Reats., J. Phy. Ohem., 59, 245 9 (1955).

51) M. M. Duhinin., Uspekhi. Khim., 24, 3 13 (1955).

52) E. R. Gilliland \& P. Harriott., Ind. Eng. Ohem., 46, 2196 2202 (1954).

53) 岡田, 池川, Tokai Techol. J., 16, 2 7 (1955).

54) E. E. Peterson \& C. C. Wright.; Ind. Eng. Ohem., 47, 1624 9 (1955).

55) E. E. Peterson, P. L. Walker Jr. \& C. C. Wright., ibid 1629 30.

56) E. E. Peterson., ibid 1630 4.

57) P. L. Walker Jr. \& F Rusinko Jr., J. Phys. Chem., 59, 241 4 (1955).

58) C. W. Zielke \& E. Gorin., Ind. Eng. Ohem., 47, 820 5 (1955).

59) H. M. Frey., Proc. Roy. Soc. (London)., A 228, 510 18 (1955).

60) 山内, 炭素 4, 153〜62 (1954).

61) 山内, ibid 5, 18 (1955).

62) 北川, 河西, 化学々工業 29, 225 30 (1955).

63) 鈴木, 日化誌, 76, 231 4 (1955).

64) 吉村, 対网, 工化誌, 58, 571 4(1955).

\section{家庭燃料の趨勢}

家庭然料は衣食住にも劣らずわれわれの生活の中に 深く根を下ろしているが，生活様式自体の推移という ものは突発的な事情でもない限りきわめて緩慢なのが 普通である。従つてその樣式構成の一要素である家庭 燃料の風貌岵よび性格は他の産業部門のものと異り， わずかの期間では目立つた移り变りははなはだ少い。 しかしながらそれを細かに観察する時は家庭燃料もま たその時々の潮流によつて支配されていることはいう までもない。たとえば都方附近の農家にプロパンガス がその然粼費の割高にもかかわらず進出していると思 えば，一面都市がスの設備のあるにもかかわらず，石
油コンロを併用する家庭もあるという。以下この一年 間の足跡をたどつてみることにする。

都市ガス，プロパンガス。電熱を 100 とし，単に燃 料費だけで比較すればプロパンガス 85，都市がス 45， 灯油 35〜 40, 木炭 40〜50, 煉炭 35〜40 となるが, ガス体燃料の簡便，清潔という文化性は年々その需要 量を増加しており，過去 3 カ年間の全国の家庭におけ るガス使用量を示すと次のとおりである。

\begin{tabular}{|c|c|c|c|}
\hline 年次 & $\begin{array}{c}\text { ガ ス } \\
\text { 需要量 } \\
\mathrm{m}^{3}\end{array}$ & $\begin{array}{l}\text { ×- } \text { 一- } \\
\text { 取付数 }\end{array}$ & $\begin{array}{c}1 \text { 月当りの } \\
\text { 月の使用量 } \\
\mathrm{m}^{3}\end{array}$ \\
\hline 28 & $1.04144 \times 10^{9}$ & $1.872 \times 10^{6}$ & 46.4 \\
\hline & $1.20311 "$ & $2.040 "$ & 49.2 \\
\hline & $1.33222 "$ & $2.237 "$ & 49.5 \\
\hline
\end{tabular}

(日本无斯協会の資料儿抛る)

また昭和 26 年頃から使われだしたプロパンガスは その後需要地域と需要量は飛躍的に増大しこれがた めに全国では現在 1000 軒以上の小売業者があるとい う。別表はプロパンガス販売量の推移であるが，この うち約 10\% が工業用に间けられ，残りが家庭用であ る。なお 12 月上旬現在で全国に抢けるプロパンがス の容器は凡そ 10 万個と推定されていたから，3月_上 旬現在の需要家数は 5 万戸前後と考えられる。

30年中のプロパンガス販売量 (単位 $\mathrm{t}$ )

1 月 622,2 月 713,3 月 1029,4 月 1101 ,

5 月 1068,6 月 1188,7 月 1353,8 月 1520 ,

9 月 1933,10 月 2128,11 月 2218,12 月 2950 ,

(全国プロパンガス拹会の㗄料による)

石油類。家庭で使われる石油類のほとんど大部分は 白灯油であるので，重油と異り大手には何等制約され ることがなく，その小売価格も 29 年度とはとんど変 りなかつたが，その消費量を知ることははなはだ困難 である。しかし石油統計月報に示す非産業用灯油の販 売量から推して年間に少くとも 20 万 $\mathrm{k} l$ は消費した ものと考えられる。

木炭, 薪。林野庁では 30 年度の木宸生産量は 29 年 度に比へ 5〜 7\% 減と推定している。その理由の一, 二としては，30 年度上半期における木㞸価格の低迷, 䝫秋の豊作に加えて，秋の天候不順のため山入り時期 の若干遅れたこと等をあげているなお不宸の生座量 は 27 年度 210 万 $\mathrm{t}, 28$ 年度 216 万 $\mathrm{t}, 29$ 年度 205 万七であり。また 30 年度の萎の生産量は凡そ 7,000 万屬積石と推定している。

睏，豆炭。㯰，豆炭の生産高は別表に示すとおりで ありその小売価格は 29 年度と大差ないが，その需要 
地域は大都市から近年次第に小都书，農村方面に移る 傾向にあるといわれている。

家庭用煉，豆炭の生産量 (単位 1000t)

$\begin{array}{ccccc}\text { 年度 } & \text { 煉炭 } & \text { 豆炭 } & \text { 合計 } & \text { 碃 } \\ 29 & 1079.0 & 122.5 & 1201.5 & \\ 30 & 1184.1 & 156.7 & 1340.8 \text { (第四四本期推定) } \\ 31 & 1320.0 & 180.0 & 1500.0 & 12 \% \text { 管の見込 }\end{array}$

\section{枯炭需要地域の推移}

\begin{tabular}{|c|c|c|c|}
\hline 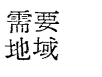 & 戦前 & $\begin{array}{l}\text { 終戦 } \\
\text { 直後 }\end{array}$ & 現在 \\
\hline 大都市 & $55 \%$ & $50 \%$ & $40 \%$ \\
\hline 中都市 & $30 "$ & $25=$ & $30 "$ \\
\hline 都市 & $10=$ & $5=$ & $20=$ \\
\hline+ & 5 & 0 , & 20 \\
\hline
\end{tabular}

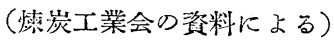

悔焼器具類。一般的にいつて細部においては若干の 改良，工夫は加元られているが，特に目新しいと思わ れる製晶はみられなかつた。

1. ガス器具類 ガスバーナおよでその附属品につ いては色々の工夫が行われていることは昨年度中に 技術相談や試験低頼のため十種類近くの器具が資源技 術試験所一持込まれたことですうなずかれる。しかし 一般的にみてな树改良すべき点が多く，従つてこれら のもので実際に商品化されたものはきわめて少い。そ うした例の一つとして，一䝫年花々しくデパートに並 ベられたガス器具て昨年度に大つてその製作を中止し たものもある。なおがス器具に関する研究としてはが スバーナ改良のための基本的研究の一つとして資源技 術試験所の沢井挍官らは二, 三の単一成分のガスにつ いて吹消元，逆火の研究老行い，ガスストーブ改良の ために産業工芸試験所の内村技官らはガスストーブの 背部の反射板の角度等を变元て輻射熱分布状態を㛟討 した。

2. 石油燃焼器具一時は数百社もあつたといわれ た石油コンロのメーカーも現在では数十社（石油コン 口懇話会々員）に減少したが売行きは順調でこの一年 間に凡そ70万台が販売されたもの之推定されている。 このように石油コンロが普及するに従つて石油コンロ による火災も飛躍的に堌加したので東京都ではメーカ 一側からの要望もあつて, 火災予防條例に基き 10 月 27日付をもつて石油燃焼器防火試験規格を設け, 低頼 に応じて製品の検査を行うことになつたが市場には最 近そうした合格品が出廻つている。なお通産省でも石 油コンロの工業規格を定めるため10月中旬からその準 備を初めた。その他石油ストーブは従来のものからほ
とんど進歩がみられず，一時は色々の型式をみせた風 呂用燃焼器は一，二のものを除いて殆ど甫場からその 姿を消した感がある。

3. 石炭ストーブ 大方の製品は旧態依然としてい たがなかには常に創意工夫を凝らしているメーカーが ないでもなくその現れとして燃焼方法に工夫を加え， デザインの面においてもかなり近代的な感賞を盛つた 貯炭式ストーブも三，三みられた。なお30年度におけ

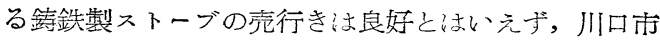
の例ではダルマストーブが例年より 1〜2 割減, 貯炭 式ストーブがようやく例年並といつたところである。 その原因は 30 年の初冬方暧冬であつたことや一般が 貯炭式ストーブの長所を認識してきたことなどによる もの之侾えられる。なおまた新興の石油コンロ業界に 引きか老舗の鋳鉄製ストーブ業界には完全な横の連 絡機構といつたものもなく，従つて規格制定を要望す るといつた気運もみられなかつた。

\section{暖房に関する趐勢}

昨年度におちる暖房の趨勢を煤煙防止の面およで燃 料, 然焼装置の面から考察してみる。

都甫の煤煙は主として暖房期に最も閣題にされるが 最近の煤煙の甚しい例にお堀のススけた白鳥などが引! 用され，終に昨年 12 月，東京都の煤煙防止條例が出 された。これは別に新らしいものではなく，戦前大阪 府その他県に公布されたことのあるものではあるが， そにかく，終戦 10 年にして東京都が始めて公害防止 公埰衛生と都市環境の浄化を困るという目標で，この 取締規定の出されたことは，特筆すべきである。

いまの日本の経済事情, 燃料設備状態て，「無煙都 书」いわゆるホワイト・シティを完成するということ は出来ないが，この條例では，都市を第一種地区（都 心部）之第二種地区に分け，「第一種の地域に㧤いて は，煤煙濃度をリングルマン 2 度点，第二種の区域で は 3 度を越えた谋煙を出してはいけない。ただし，点 火時またはかま替えによる火層調整の場合は，1時間 につき総訐 6 分以内，その他の場合は 1 時間につき総 計 4 分以内はその限りでないというょうに決めてい る。

煤煙防止の取締については，古く米国の都市で実施 されているが，Bureau of Mines, Bulletin 537 で は「然気活染」の編輯交献集を発行している。また英 国では Beaver 報告に基いて，無煙燃料々燃焼の機械 化が強調され，蝶煙による損失を金額にみると年 150 
百万£で，これに各種設備の効率の損失を加算する と，実に250百万£を下るまいとしている。そして 現在家庭然料向に使用している 500 万 $\mathrm{t}$ の石㞸を今後 20 年で，20\% 無煙固形燃料に，40\%を電気に転換す ると計画している。

さきに述べた東京都の谋煙防止條例の出されるまで の準備期に拈いては, 都民室が中心となつて関係管庁 団体が拹才して都内煤煙発生の実態調查を 1 ～月に 亘つて行つた。この結果から指摘されたことは, 設備 燃料，技術の何れの面に掻てても不充分であり，今後 罰則をともなう條例が出されても，まず積極的な啓蒙 指導の緊急性が強く認められた。

戦後新らしく建設されたビルの暖房設備は, 完備し ているが, 古ビルの䁔房設䚛は甚しく老朽化し, 或は 戦後の応急的な補修工事で，特に駐留軍の使用してい るものは，生活様式の相違から日本人よりも高い暖房 温度が要求され，法いぶイラの負荷が過重となり，甚 しく煤煙觉発生する傾向が強く, また管庁ビルは蒸汽 暖房が末だ復活せず，低然としてストーブの煙突が林 立し，蒙々たる黒煙を発生する傾向にあつた。

また煤煙防止の対策はさらに燃料面から之燃焼装置 の面からと大にに検討された。すなわち然料の面では コークスと無煙孷が暖房燃料として著しく進出した。 せクショナル缶におけるコークス焚は，大東工業所が 三菱化成, 東京コークス之協力して, 着火アーチと中 空火格子を用いた改造装置の研究 (三菱化成ビル, 東 大農学部ゼル) が行われた。また無煙炭については， 「チクラ特汾」を使用した三井吰山(株)の試験(日本興 業銀行ビル，三楽病院）などが行われ，荻城無煙につ いては常磐ビルの公開実験などがあつた。

その他燃㜔装置としては，ガス化或は半ガス化式の ものが現われた。特に「無㖶ボイラ」と呼ばれるもの があるが，これはがス発生炉とガス梦ボイラをがス管 て接続したもので，ガス拉よびスールの発生が時間的 に著しく变化し，必ずしも所期の無煙，効率的な燃焼 は行われなかつたようである。

煤煙発生の甚しい手焚小型燃焼装置には, 下込式 トーカを使用する方法或は下込式ストーカと階段火格 子を併用するような機械梦の方法が現われてきた。一 方においてスプレッダー式のストーカが相当関心が持 たれてきたが，これと同時に新にシンダーの飛散が問 題とされ、煤煙とともにこれが対策としてウォータス プレー式，サイクロン式などの除麃装置などが出てき た。しかしこれは中小設㣁向けとして一般性に乏し いようで, 要は, 燃燒装置において煤煙やジダーを
発生しないような対策にその重点がおかれた。

助然郕或は消煙剤といわれて市販された薬品も数多 く, 液体燃料に使用して効果を顕わしたものは相当あ つたが，石炭に混じて使用するものは，著しい效果を ほとんど出していない。

なお，煤煙防止に関して，中央熱管理協議会が，煤 煙防止特集号(10月号)を発刊し，また10月東京都が ガス協会において都市煤煙防止座談会觉関係者多数集 めて実施したことはこれまた特等すべきであろう。

\section{煉崖エ業の䟉勢}

\section{1）䗲豆炭需要の趨勢}

最近東京都から発表された資料によると, 都内の主 要家庭燃料の消費指数は次のとおりである。

\section{第 6 表 東宗都家庭燐料消費指数調}

\begin{tabular}{|c|c|c|c|c|}
\hline 区分 & 27 & 28 & 29 & 30 \\
\hline 炭 & $34.2 \%$ & $27.4 \%$ & $22.4 \%$ & $20.3 \%$ \\
\hline 亲 & 15.1 & 12.7 & 10.7 & 9.6 \\
\hline 炭 & 9.8 & 11.4 & 11.3 & 12.0 \\
\hline 炭 & 0.8 & 1.0 & 1.1 & 1.3 \\
\hline 油 & 42.0 & 11.2 & 20.2 & 22.2 \\
\hline x & 35.9 & 36.3 & 34.3 & 34.6 \\
\hline & $\begin{array}{l}100.0 \\
166.5 \overline{\text { 和 }}\end{array}$ & $\begin{array}{l}100.0 \\
1.735 \\
1.75\end{array}$ & $\begin{array}{l}100.0 \\
182.8 \\
\text { Fन }\end{array}$ & $\begin{array}{l}100.0 \\
190.8\end{array}$ \\
\hline
\end{tabular}

煉豆炭以外の然料については他の項で詳説せられる と思うからここててはあまりふれないが，上表によれ ば木炭, 薪の消費がここ数年間に急激に減少し灯油 が，著るしく増加している。徚豆炭はここ数年毎度約 2 割づつ增加しているが，指数では㬐少の堌加に止つ ているのは，家庭然料の消費全量が世带数の増加にし たがつて増加しているため,であ。この表は, 東京都 の数字であるが, 大都市の主要家庭燃料消費の一般的 な赹勢と考元られる。

全国の煉豆炭生産実績は日本谏炭工業会の調へによ ると,

(単位千 $t$ )

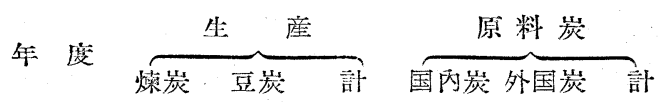
$\begin{array}{lllllll}29 \text { 年度 } & 1079.0 & 122.5 & 1201.5 & 845.6 & 136.8 & 982.4\end{array}$ $\begin{array}{lllllll}30 \text { 年度 } & 1184.1 & 156.7 & 1340.8 & 959.0 & 136.4 & 1095.4\end{array}$ 30年度注第4, 4年期推定を含む。

枯炭の生産は $20 \%$ 増, 豆炭の生産は $28 \%$ 堌, 合 計において $12 \%$ 増となつている。31 年度は煉炭 1,3 20 千 $\mathrm{t}$, 豆岸 180 千 $\mathrm{t}$, 合計 1,500 千 $\mathrm{t}$ の生産方計画 されてるい。 
2) 煉豆炭の品位と原料炭

戦前枯炭の原料崖の大部分は平猿無煙炭で，これに 仏印拉よび北支の無煙炭が配合せられ，内地の無煙孷 は地方的または補助的に使用せられたものである。

終戦後は内地炭ことに大領の無煙炭が主原料となつ た。昭和 26 年度より仏印ホンゲー岸, 韓国の三陟宸 が輸入なられるにおよび著るしく品位は向上した。 30 年度の原料炭の内 136.4 千 $\mathrm{t}$ はホンゲー炭拉よび韓国 の土賽黑煙で主として徚炭の原料として使用されてい る。外国炭の使用割合は 28 年度の 170 千 $\mathrm{t}$ には遥か に区ばないが，内地炭も山陽洗炭のことも書く，大領 煙炭の水洗発熱量の高い九州炭の使用割合の増加した ことと製造上不断の研究努力の結果徚崖の品位はます 宗す向上している。

品川燃料の研究室の調査によると, 京浜間の主要製 造工場の高 4 寸徚炭の燃焼試験成績は次のとおりであ る。

\begin{tabular}{|c|c|c|}
\hline 年月 & 総点数 & 砋痛 㾉 \\
\hline 27年 4月 & 159.8 & 外国壳艎し \\
\hline 27华 9月 & 211.0 & 外国売加わる \\
\hline 28年 1月 & 213.2 & \\
\hline 29年 4月 & 225.0 & \\
\hline 29年12月 & 230.0 & \\
\hline 30䈉 5 月 & 255.0 & \\
\hline 30年12月 & 266.0 & \\
\hline
\end{tabular}

最近の高 4 寸煉炭の成績は戦前の 4 寸徚㞸の成續に 達した。これは原料炭の平均カロリーは戦前に未だ区 はななが，寸法の大きくなつたことと，强力な成型機 在使用して強圧の下に成型寸るため徚㟶 1 個当りの重 量が遥かに重くなつたためである。豆炭の原料は同じ 無煙炭といっても煉炭とは異る。煉炭は長時間の使用 にたえるのと通風孔がある為め土壤黒煙のような燃焼 法の低い原料も使用できるが，豆炭が火鉢で立消えし ないためには，燃焼性の高い原料が必要て戦前は樺太 の内幌のニーライト粉が使用せられたが，終戦後は原 料難のため一時ほとんど姩息の状態にあつたが，最近 は天草の無煙炭を使用するようになり，再び急速に増 産されるようになつたが，原料炭が制限せられるので 急激の増加觉続け得るがううかは疑問である。

3) 莱豆炭靁要の変遷

戦前燤豆炭の需要は主として大都市の一般大衆の或 房用および大寸物は業務用, 風呂用および農村におい ては養虫用，ホップ乾燥用などであつたが，大都市の 瞦房用はガス抢よで石油ストーブの普及て減つたと思
われるが，比較的温䁔の本州の大都市䁔房用に消費せ られるようになつた。これには信州方面で主として使 用せられていた 3 尺西角の掘炬燵が終戦後都市におい て急速に普区し，この燃料としてほとんど徚炭方使用 せられるようになつたのもあずかつて力がある。この 目的に副うため京浜の徚炭工場で一時製造を中止して いた 3 寸煉崖も最近ことに 30 年度以後盛んに製造 せられるようになつた。6 寸ものの煉炭は都市の暖房 用としては，畳 6 畳の二閒続きの室に, 細い煙突老つ

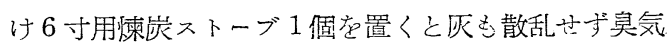
もなく夕方から夜の 12 時頃まて二間とも丁度適当の 温度に保たれるので, 最近この種のストーブが, 子女 の勉强室に使用されるようになつた。䗲炭つ需要とし て最近最も著しい現象は, 農村ことに東北地方つ農村 に多量に使われだしたことである。

戦前も, 養亘用およびホップ乾燥用に大型煉炭が可 成り使用せられたことは前にも述べたが，養虫用こそ， 養虫の減少とともに戦前よりも減つているが，ホップ 乾燥用の他麦および煙草の乾燥用に用いられる他, 東 北及び新潟地方の水田地带は農村の燃料が不足するの で，最近は高 4 寸煉炭が使用される様になつた。一時 ほとんど閉鎖されていた，仙台市の徚炭工場が復活せ られた他 30 年度には東京附近の煉炭工場の製品が 30 年度に 2 万 $\mathrm{t}$ 以上東北に移出せられた。この傾向は ますます増加の傾向にある。

これらの地方の需要増加が，大都市において，ガス が普交し石油ストーブの增加にもかかわらず，煉豆岸 の需要が東京都の煉炭工場で毎年 2 割程度増加してい る理由と考えられている。

4) 枯炭の燃焼器えの発達

1) 上付コンロ

煉炭の欠点は着火が面倒なことで, 之の対策として 着火炭や煉炭に着火炭をつけだ交化煉炭が眅売されて いるが色々の理由からあまり普及しなかつた。煉炭は 下から火を付ける一般常識を打破したのが上付コンロ である。

上付コンロの特長はＡ）小量の木炭があればほとん ぞ焚付もいらず，火がつく B) 燤炭の上に置いた木炭 が先つ燃焼するのて着火後 5 分間もすれば煮炊ができ る。( C燃焼睸が最高部にあり二次空気が充分供給さ れるので悪臭吟 CO の発生が全くない。下方のダン パを加隇することによつて火力を自由に加隇すること ができる。煉崖全体が保温されているので, 完全に然 焼させることができるので未燃物を残すことがないな ぞ, 長所があるので, 29 年度から販売されたのであ 
るが，30 年度は煉炭燃焼器具はほとんぞ上付コンロ に等光せられた観があつた。な唗従来は煉炭のコンロ と火錸は全然別の用途之㘼えられていたが上付コンロ はそのまま火鉢に大れることができるので，同一ュン 口を台所でも使い西之を火鉢に大れて座敖でも使うこ とができるしまた悪臭やCO がないので炬爟に使って も便利である。

2）天広火鉢の普及

各種の煉炭火錸は戦前から使われていたが，安洒の ものが多くあまり普及しなかつた。座敷の燃焼器具と しては，長火鉢が王座を占めていたが，終戦後長火鉢 はほとんと影をひそめてしまつた。これに代るものと して，天広の䍒炭火鉢が使用されるようになつた 30 年度は，天広火鉢の需用が旺盛で製造が間に合わ好有 様であつた。また 30 年度は, 本焼の天広火鈹需用が 増加したことも 30 年度の新らしい現象であつた。

\section{鉄道用燃料の遛勢}

（1）固体燃料 国銑の固体燃料消費量は，電化と ジーゼル化との進展に伴い漸減の傾向をたどつてい る。(第 8 表参照) 購大石炭の平均発熱量は鳌約保証 平均で $6,390 \mathrm{kcal} / \mathrm{kg}$ (前年 $6,475 \mathrm{kcal} / \mathrm{kg}$ ), 前年より 低くなつたが経済事情から実際の平均品位は数百カ口 リー高い見込である。

\section{第 8 表 国鉄の固体然料消費量}

昭和29年 昭和30年 增 減 運転用石炭 $3,915 \times 10^{3} \mathrm{t} \quad 3,688 \times 10^{3}$ 減 $227 \times 10^{3}$ 運本朋煉炭 $1,189 \times 10^{3} \cdot 1,348 \times 10^{3}$ 僣 $159 \times 10^{3}$ 船舶用炭 $214 \times 10^{3} \quad 186 \times 10^{3}$ 減 $28 \times 10^{3}$ 発䨵用炭 $58 \times 10^{3} 59 \times 10^{3}$ 陉 $1 \times 10^{3}$ 工場用炭 $96 \times 10^{3} \quad 95 \times 10^{3}$ 減 $1 \times 10^{3}$ その他 $220 \times 10^{3} 230 \times 10^{3}$ 䇠 $10 \times 10^{3}$ 計 $5,692 \times 10^{3} \quad 5,606 \times 10^{3}$ 減 $86 \times 10^{3}$

銑道用炭として他の一般産業之異る点は，塊粉割合 である。一般産業では塊 $26.4 \%$ 粉73,6\% に対し鉄道 用は塊 $62 \%$ 粉 $38 \%$ となつている。これは蒸気穖関 車の特性として粉が多いとシンダー損失が多くエネル キ消費量が增すからである。熯炭は前述のようにェネ ルギ消費量を減ずる目的で塊峞の役目をさせているの で, 前年に比して消費量は増加している。本年の煉炭 使用状況は第 9 表のと抢りである。

\section{第 9 表 煉炭の使用状況}

保証品位 $\quad 7,000 \mathrm{kcal} / \mathrm{kg} \quad 6,800 \quad 6,700 \quad 6,600$ $6,400 \quad 6,000$

$$
\begin{array}{llll}
\text { 使用量 } & 61 \times 10^{3} \mathrm{t} & 69 \times 10^{3} & 145 \times 10^{3} \\
& 954 \times 10^{3} & 27 \times 10^{3} & 94 \times 10^{3}
\end{array}
$$

$7,000 \mathrm{kcal} / \mathrm{kg}$ は甲種 3 号 (無煙㷄炭) で前年より約 3 万tの減少をみたが高カロリーの無㖶炭の経済事情 と使用効率との面から生じたものである。昨年は 5,6 $00 \mathrm{kcal} / \mathrm{kg}$ の煉崖が使用されたが，高品位棌ど使用效 率がよいので本年は使用されなかつた。

（2）液体然料 ジーゼル化は世界的な趨勢であり ジーゼル軽油の消費は増加している。讫の他徚㟶と重 油嘪射による併燃も漸増している。第10表は液体燃料 の消費成績である。電化の進展に伴いSGI ボイラに よる暖房用の洗涤軽油の消費量も増加している。ここ て間題を投げかけられているのは炤和 31 年度から洗 滌軽油に課税され暖房費が高くなるということであ る。

\section{第10表 匡鉄における液晔燃料使用量}

昭和 29 年 昭和 30 年

ジーゼル軽油 15,645k $l \quad 44,921 \mathrm{k} l$

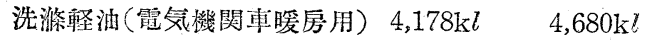
B 重 油(混燒用)
$60,451 \mathrm{k} l$
$71,100 \mathrm{k} l$

（3）試験研究、煉炭の発熱量および然紏費が蒸気 機関車の燃料消費量におよほすす影響が喜多氏1などに よつて試験研究された。発熱量だけ異り他の性状（形 状, ピッチ混入量, 燃料比, 粘結性なと゚) が相似た数 種の煉炭を試作して中央線て試験した結果，荷重の大 小とも発熱量の堌加と共に燃料消費エネルギが減少し その隇少の割合は 6,000〜7,000kcal $/ \mathrm{kg}$ 閒は大きく, $7,000 \mathrm{kcal} / \mathrm{kg}$ を越すと次第に小さくなることがわか つた。その原因として発熱量の增大とともに未燃炭損 失が小となることが確められた。燤宸の発熱量を 6,60 $0 \mathrm{kcal} / \mathrm{kg}$ から $7,000 \mathrm{kcal} / \mathrm{kg}$ にすることによつて然 料経費だ $5 \%$ 節約できる計算となる。楮炭の燃料比に ついても前と同様な試験を行つた結果，燃料比は 1〜 1.5 の間が最適で，それ以上となるにつれて撚料消費 量は次第に増加する。その主な原因は煉炭の然料比を 犬にするには無煙炭の配合割合が増大するがこれにつ れて㚒がらおよびシンダーの炭素損失が大となること が主としてあり゙られる。煉炭の燃料比を大にして煤煙 防止をはか乃うとすれば，蒸気機関車の燃料費用が増 すことになる。

石炭に撒水したときの蒸気機関車燃料消費におよほ す影響について試験つが行われた。中塊炭では湿分 $2 \%$ (自然附着水分)上り多くの撒水を行えば然料消費 量は増加する。重荷重斢引の場合中塊炭 70 粉炭 30 では湿分 $8 \%$ 前後，中塊炭 50 粉炭 50 では湿分 $10 \%$ 
前後て燃料消費量は max. となつた。燃料消費量の max. は粉炭の混大割合が増大寸るにつれて低くなつ ている。撒水すれば燃焼がス損失が堌大する䇢である が，max.が存在するのは撒水によりシンダー損失が 減少して燃焼がスの持逃げ損失をカバーし，かつ水分 蒸発に上り火室内の拡汼作用に上る燃焼促進が行われ るものとと推定された。

1) 喜多, 布施、鉄道業務研究㫅料，13 卷 4 号 (31年 2 月)

2）吉村，丸仙同上に近く発表の予定。

\section{タールエ業の遛勢}

（1）生産，昭和 30 年のヌール製品の生産につい て々ると，前年秋以来鉄鋼輸出の好転を機に一般経済 活動も激く活況を示し, 鉙工業生産指数も逐月上伸を 示し、タール製品関係にあつては, 製鉄業はもちろん のこと，都市がス事業も，また化学工業部門も順調な 歩及を示したので，ヌール製品の生産は本年初めから 高水準の生産を続け, 過去最高の昭和 29 年を菱ぐ記 録を示した。

まずタール製品の根源である原料石孷についてみる 々，高温乾溜に打いて製鉄部門は 5,228,695 t で 8\% 増, 都市がス部門 (地方中山ガス工場を除く) は 2,84 0,273t で 9\% 增, 化学工業部門 $1,048,377 \mathrm{t}$ で 7\% 増で，前年に比し減少を示したのは「「との他」部門 で 114,799 t の 11\% 減，全体としては前年実績 8, $553,346 \mathrm{t}$ に対し 9,232,144 t と $8 \%$ 增を示した。こ の外低温乾溜におういては，212,085 t で前年実績 196, $908 \mathrm{t}$ に対し $8 \%$ の増加を示した。

これらの原料石炭からのタール製品の生産は第11表 のとおりで，ベンゾール類製品は前年に比し $14 \%$ 增 と著しい増革を記録し，就中純ベンゾール，純トルオ ールおよびソルベントナフタの増産が顕著であつた。 特に純ベンゾールの生産は戦前戦後を通じての最高の 生産を示し，ベンゾール類製品全体としての $73,052 \mathrm{t}$ も同様最高水準を示すものであつた。また原料石炭妈 理量の増加に比しベンゾール類製品の増加率が高いの ふぶンゾールの回収抢よび精製歩溜の向上の跡を示す ものである。

コールタール分溜製品については, 前年に引続きタ ール酸の増産が顕著で，コールタール分溜製品全体と しては前年に比し $7 \%$ 増を示した。精製ナフタリンも $17,123 \mathrm{t}$ で前年に比し $5 \%$ 増を示し，純ピリジンは
前年不振であり, 8 月頃より生産も恢復を示したけれ ともも，年間を通してては 45,577 kg で前年に比しなお 30 $\%$ 減老示した。

昭和 31 年の見透しとしては，製鉄業においては造 船なぞの好況を反映して好調を続けるものと予想さ れ，また現在のところ昭和 31 年度（会計年度 4 月〜 32 年 3 月) に打る出銑計面も560〜 570 万 $\mathrm{t}$ と伝元 られこれに伴うヌール製品の増産が期待される。都 市がス部門に执いては年々増大寸る需要に対して生産 設備の拡張に次ぐ抎張を続け，本年もタール製品の増 産は確実に期待できよう。

\section{第11表 昭和 30 年タール製品生産量 (単位 $\mathrm{t}$ )} (高溫乾溜)

\begin{tabular}{|c|c|c|}
\hline & 类 & \\
\hline 品 & 30年 & 29年 \\
\hline ベンゾール類製品 & & \\
\hline 純ベンゾール & 40,556 & 33,212 \\
\hline 純トルオール & 7,738 & 6,684 \\
\hline キシロール & 1,231 & 1,223 \\
\hline 溶剂級ベンゾール & 18,455 & 19,513 \\
\hline 90\%ベンゾール & $(9,484)$ & $(11,643)$ \\
\hline 60\%ベンゾール & $(5,390)$ & $(4,355)$ \\
\hline (40\%ベンゾール & $(3,581)$ & $(3,515)$ \\
\hline ソルベントナフタ & 5,072 & 3.898 \\
\hline コールタール分溜製ロ & & \\
\hline ベンゾール吸收油 & 25,330 & 24,120 \\
\hline クレオソート油 & 105,203 & 99,707 \\
\hline ピッチ & 255,455 & 236,882 \\
\hline 粗製ナフタリン & 28,692 & 28,065 \\
\hline 粗製アントラセン & 4,783 & 4,616 \\
\hline タール酸類 & 5,511 & 4,655 \\
\hline ( 分溜石炭酸 & $(1,637)$ & $(1,207)$ \\
\hline クレゾール酸類 & $(3,063)$ & $(2,810)$ \\
\hline そこの他のタール酉 & 類 (811) & (638) \\
\hline 精製ナフタリン & 17,121 & 16,243 \\
\hline （含圧搾ナフタ & ン) & \\
\hline 精製アントラセンC & g) 30,070 & 27,877 \\
\hline 精製カルバゾール & g) 10,420 & 5,675 \\
\hline 純ピリジン(kg) & 45,768 & 65,657 \\
\hline
\end{tabular}

（低溫乾溜）

\begin{tabular}{|c|c|c|}
\hline 品 & 30年 & 量 29 年 \\
\hline \multicolumn{3}{|l|}{ ベンゾール類製品 } \\
\hline ソルベントナフタ & 1,555 & 1,341 \\
\hline へビーナフタ & 192 & 109 \\
\hline \multicolumn{3}{|l|}{ コールタール分溜製品 } \\
\hline ベンゾール吸收油 & 788 & 747 \\
\hline クレオンート油 & 9,591 & 9,898 \\
\hline ピッチ & 7,702 & 6,279 \\
\hline クレゾール酸類 & 545 & 573 \\
\hline その他のタール酸類 & 95 & 98 \\
\hline
\end{tabular}


（2）輸出大 炤和 30 年に抢けるタール製品の輸出 については, コールタール535t, ピッチ 2,610 t, ナ フタリン $371 \mathrm{t}$ ，クレオソート油 $10,663 \mathrm{t}$ で主として 東南アジア諸国に輸出され，クレォソート油はアジア 諸国の外，前年に引続き米国向けに大量輸出された。

輸大はベンゾール 1,588 t, トルオール $129 \mathrm{t}$, ナフ タリン $2,197 \mathrm{t}$ ，クレン゙ール $277 \mathrm{t}$ であつた。この外 相当量のキシロール(推定 1,500 t) 新よびソルベント ナフタ（推定 $400 t$ ）の輸大をみた。

前年に比較して顕著な点を挙げてみると, ベンゾー ルは前年に台湾向けに輸出されたのに対し，本年は逆 に1,588 $\mathrm{t}$ と米国よりタンカー輸大を見，トルォール はTNT 用の需要減退のためその輸大は著しく減少し た。ナフタリンは前年日亚貿易協定に基ずき多量の輸 出 $(1,500 t)$ をぬたが，本年はわずかに $250 \mathrm{t} に と と ゙$ まつた。クレン゙ールは前年 $2,503 \mathrm{t}$ の輸入であつたの に対し，本年は $277 \mathrm{t}$ にとどまつた。

（3）需給 昭和 30 年におけるヌール製品の需給 状沉を概略すれば，上述のごとく生産は顕著な堌産を 示したが, 就中, ベンゾール類製品の戦前戦後の最高 記録を示しているのにもかかわらず，需要はさらに活 発で市況は極度の堅調に終始した。すなわち純べンブ ールは合成繊維抢よび合成石炭酸の増産態攀の確立に よつてその需要は着実に伸び, 増産に次ぐ増廉を以て しても賄うことができず，遂に 10 月に $1,500 \mathrm{t}$ 米国 よりタンカー輸大を行つた。純下ルォールについては TNT 用の需要減退によつて軟調を辿るかにみえたが 塗料溶哓としての需要が活発となり, 前年度末の大量 の在庫を一掃するに至つた。キシロールおよびソル心゙ ントナフタは合成樹脂塗料の躍進により, 溶剤数ベン ゾールも塗料方面の旺盛な需要のため, 国内品のみで は大巾の不足を来し，上述のごとき輸大で需給の均衡 を図つた。しかしタール系溶剤のみではまだ充分では なかつたため, SBP (Special boiling point 䒴香族 $60 \% \sim 70 \%$ ), HAWS (High aromatic white spirits 芳香族 $40 \%$ 程度）などの石油系溶剤の輸入によ り需給の均衡化を図つた。

コールタール分溜製品中, ピッチは徚炭用, ピッチ コークス, 電極用の荃実な需要により需給は程よいバ ランスを得た。タール酸類は前年における過剩輸入に よつて，市況は軟化状況を呈したが，それでも年初め には，1,100 t も在庫を抱元ていたが，遂月漸減し，一 時は市況好転するかにみえたが，高沸点ものの需要が 振わず相変らず相当量の在庫を抱えている。ナフタり ンは引続く無水フタル酸の生産拡大によりヌ一部の染
料中間物の輸出の影響によつて, 需給の逼迫を来たし 前述のごとく多量の輸大をみた。純ピリジンは前年来 不振であつたが, 逐次需要き恢復し, 年初 $70 \mathrm{t}$ の在 庫も逐月漸減し， 7 月頃より再び月平均 $7 \mathrm{t}$ 台の生産 を行い順調な推移を示した。

（4）規格 昭和 27 年 5 月制定をみた JISK 2405 ヌ ール製品(タール塩基類)，JISK 2406 タール製品（加 エヌール), JISK 2407 タール製品 (タールピッチ)は 有効期間 3 年を経過し, かつその間生痷技術の進歩, 品質の向上，新需要面の開拓などにより JIS 改正の 必要となり日本タール協会に批て原案を作成し，日 本工業標準調査会の審議を了し, 昭和 30 年 4 月 14 日 改正された。

(5) 操業状況

八幡製鉄 9 月精製カルバゾールの生産を再開した。

富士㱔鉄（釡石製鉄所） 2 月第 4 ニークス炉（黒田 式 35 門) 操業を開始した。同じく連続式純ベンゾー ル蒸溜装置が新設され運転を開始した。

富士製鉄（室蘭製鉄所） 12 月連続式軽油蒸溜装置 (パイプスチル 36t/日) が新設され運転を開始しだ。

東京瓦斯(大森工場) 3 月油ガスよりの粗軽油の回 収を開始した。

東京瓦斯(千住工場) 10 月粗軽油の回収を開始した。 大阪瓦斯（舎密工場）1月オットー式コークス炉 (31 門 390t/日)の操業を開始した。

東邦瓦斯(桜田工場) 9 月粗軽油の回収を開始した。 (6) その他

日本タール協会においてはタール工業の増産並びに 合理化に関し，技術的経済的に種々検討を加えていた が，一応結論を得たので，10月「タール製品増産方策」 なる小冊子を編し，広く業界内外に呼びかけた。また 当局に捺いても石炭化学工業の重要性を認め, 石炭化 学技術懇談会(委員長黒川真武氏)在設置し, 当面の石 炭化学の諸問題を採り上げて討議した。タール工業も 石炭化学工業の一翼として取上げられ, その増産対策, 合理化対策は通産大臣宛の答申にも明確に謳われた。

\section{コールタールに関する研究}

中性油この部門ではタール成分の検萦に関するも のの外は石油化学と直接間接に関連のある研究が多 い。まずタール成分の検索については, 武内氏らは心゙ ンゼン前溜分中に従来認められていないインプレンの 存在を認め,また0.7〜1.3\%のアセトンの存在も確認 している。また頁岩タール中性油分のクロマトグラフ 
による分離, 泥炭タール中性油 $200^{\circ} \mathrm{C}$ 以下溜分の成 分などの研究もある。Jäger 氏らは低温タール中の炭 化水素を分溜, ラマンスペクトル，水素添加なとによ つて詳細に研究し, Treibs 氏らは褐炭タール中の $110 \sim 150^{\circ} \mathrm{C} / 13 \mathrm{mmHg}$ の溜分中にアズレン $\left(\mathrm{C}_{10} \mathrm{H}_{8}\right)$ およびその同族体の存在を認めている。ソルベントナ フサについては, 日比野氏らは $160^{\circ} \mathrm{C}$ 以上の溜分よ り蒸溜とスルフォン化によつてトリメチルベンゼンと セドリンデンを分離し，なおクマロン，インデンなど を分離してそれらの物理恒数を測定した。岸化水素混 合物よりの芳香族の抽出については, 吸着分離や共沸 蒸溜によるものが多く, 黒川氏らは芳香族㞸化水素と シリカゲルの吸着によつて分離する方法について研究 し，特にシリカゲル製造法に関し顕著な良好な成果を 挙げだ。高橋氏らはジメチルホルムアミドに流動パラ フィンを加え溶郕で抽出を行つた。この外 2 -ピコリ ンやアセトンとの共沸を利用しに研究もあり,また孷 酸エチレンなとによる抽出方法も提案されている。粗 ベンゼンの精製方法として, シリカーアルミナや活性 炭を用小常圧気相で高温で処理した後に硫酸洗涤して 樹脂化傾向のある不飽和分の一部を芳香族炭化水素に 変光る方法, 酸化もリブデン, アルミナなどの触媒を 用いて加圧接触水素添加する方法や安東氏のモりブデ ン系触媒を用いて加圧水素により脱流する方法などが ある。また㸃化アルミニウムのような金属八ロゲン化 物に酸化チタンのごとき促進郕を加えたものを接触成 としてパラフィン，ナフテン類を除去する方法もあ る。この外粗ベンゼンの連続蒸溜, パイプミキサーに よる硫酸洗滌についての研究もある。芳香族炭化水素 の異性化については $p$-キシレンを目標としたものが 多く, 武上氏らは $m$-キシンンを水素加圧下で白金触 媒で, 八田氏らは常圧, $450 \sim 500^{\circ} \mathrm{C}$ て水素気流中 で，または加圧下， $450^{\circ} \mathrm{C}$ で異性化を行つている。 Pitts 氏らはキャットフォーミング触媒局い，2段 階で処理して $m$-キシンンより $p$-キンレン $22.4 \%$ を 得ている。異性体混合物の成分々離研究としては, Haines 氏らはキシレンの深冷分離について遠心分離 之再結晶を行い, 純度 $95 \%$ の -キシレンを分離し, 竹田氏らは抽出蒸溜抢よで承結法を行い, 水結法はア セトン添加によつて抽出蒸溜より純度のよいものが得 られることを述べている。また McCaulay 氏らは $\mathrm{TiF}_{4}-\mathrm{HF}$-キシレン複化合物を触媒として $\mathrm{C}_{8}$ 芳香族 を異性化し， $m$-キシレンに富むキシレン混合物を得 た。また同氏は同じ触媒をキシレン類の゙゙ンゼン,エ チルベンゼン，飽和炭化水素などからの分離に用いて
いる。芳香族炭化水素の合成および変換についてはア ルキル化反応に関するものが多く，フリーデルクラフ 卜反応を利用方る方法の外, 新しい触媒やアルキル化 鼡が提案されている。例えば堤氏らは心゙ンゼンをエチ レンでアルキル化玄るのに $\mathrm{CuO}-\mathrm{PO}_{4}$ 孛触媒として用 いて抢り，エチレン，プロピレンを含む石油分解がス でベンゼンのアルキル化を行うとエチレン, プロピレ ン単独の場合より容易で且同時にキュメン, エチルべ ンゼンなどを好収率で得ることを述へている。この外 ベンゼンとアルキルハライド, アルミニウム蓺した 中をオレフイン整と扎してモノアルキルベンゼンを得 る方法や，アルコールとベンゼンを触媒上を通ずる方 法があるが, Suǐkin 氏らのエチラール,エーテルなど 整用いたベンゼンのエチル化は好収率を得ていないよ うである。また同氏のホルムアルデセドまたは酸酸に よる心゙ンゼンのアルキル化もトルエンなどを少量得て いるのみである。さらにアルミーシリケート触媒, $\mathrm{AlCl}_{3}-\mathrm{H}_{2} \mathrm{SO}_{4}$ の存在で塩化アルキルによるベンゼン のアルキル化，アルミナと塩化西鉛触媒で加圧接触ア ルキル化，ジカルボン酸エステルと塩化アルミニウム によるアルキル化など，ベンゼン類のアルキル化の研 究は頗る多い。芳香族炭化水素の不均化反応による低 級または高級炭化水素への転換方法として，McCau-

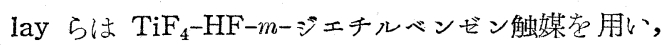
エチルベンゼンよりジまたはトリエチルベンゼンを, また同様にしてキシレンよりトリメチルベンゼンを多 量に得た。また Garrilov 氏らのアルミノシリケートト 触媒による $300^{\circ} \mathrm{C}, 15 \sim 20 \mathrm{~atm}$. の不均化反応もある。 高級芳香族炭化水素の低級化の方法として, 水素圧力 下に高温に処理して低級化方方方法がある。非芳香族 炭化水素, 殊にパラフィン族孷化水素よりの芳香族炭 化水素の合成法は石油工業に関連するものが多いが, Beyer はフードリフォーミングについて研究し， Donaldoson らはフィシャ一合成法によるパラフィン を用いてプラットフォーミングを行い, 脱水素, 環化 による芳香族の生成に関しその温度, 空間速度などの 影響について研究している。Taylor 氏らはェチレン より合成した直鎖状不飽和峞化水素を $\mathrm{Cr}, \mathrm{Mg}, \mathrm{Al}$ 在 含む触媒で芳香族化して $p$-キシレン度得, またへキ サンなぞをクロミアアルミナ触媒で芳香族化してい る。芳香族炭化水素の酸化については $p$-キシレンの 酸化に関する研究が領る多い。たとえば秋吉氏は $p$ キシレンを液相でさらに $p$-トルイル酸メチルを空気 酸化している。Yen 氏らは硝酸々化でトルイル酸之 テレフタル酸在得, 低温で発烟硝酸による酸化も行つ 
た。堤氏は初圧 $30 \mathrm{~atm}, 60^{\circ} \mathrm{C}$ で加圧酸化し，収率 $43 \%$ でハイドロパーオキサイドを得ている。この外， $p$-キ シレンの自勳酸化やハイドロパーオキサイドに関する 研究, 酸化バナジウム々酸化モリブデンでベンゼンを 酸化する無水マンイン酸の製造の研究なぞがある。ま た保坂氏等は酸化促進剂を大れてその酸化の因子を求 めている。p-サイメンの酸化によるテレフタル酸の合 成については堤氏らは 20〜40atm で加圧酸化し，テ レフタル酸を $60 \%$ 以上の収量で得, Serif 氏は $p$-サ イメンの液相酸化の研究を行つた。この外, クメンの 酸化，p-ジイソプロピルベンゼン，第 2 級ブチルベン ゼンの酸化，トルエンの加圧空気酸化抢よび稀硝酸高 温高圧酸化などがある。Griell 氏はなルエンをクロロ メチル化しこれを塩素化した後に塩化鉄の存在下で 水々区応せしめてテレフタル酸を得た。その際の中間 生成物である $p-\mathrm{C}_{6} \mathrm{H}_{4}\left(\mathrm{CCl}_{3}\right)_{2}$ とメタノールよりテレ フタル酸ジチルを得た。生成した酸の分離, 精製につ いては，第3級アミン盖として分溜と再結晶によるイ ソフタル酸とテレフタル酸の分離，愹融状態で無機酸 のアルカリ金属塩溶液を加元て減圧蒸溜するか或はア スファルトなどと熱して滅圧蒸溜するというフタル酸 の精製方法がある。この外， $p$-サイメンの脱水素によ る $p$ - $\alpha$-ジメチルスチレンの製造，クメンの銅クロム 触媒による脱水美による $\alpha$ はチルスチレンの製造, トルエンの水素添加分解によるべンゼンの生成などの 研究がある。

多環芳香族炭化水素については, 高沸点溜分の成分 桧索やそれらの合成方法, ナフタリンなぞの分別結晶 や回収方法の改良などに関するものが多い。まづ成分 榆索法としては分溜, 抽出, クロマトグラフを繰返え して行う操作が多く，Beránkovaは壁に附着したタ ール物質よりベンッピレンを遊離確認し, この外下リ ニダット原油より数種のトリメチルナフタリン, 未知 のエチルメチルナフタリンなどの分離確認や, 石炭, 石油の水添分解で得られたコロネンの研究やナフタ リン油の中性油の溜分の硫黄分布の研究がある。ナフ タリンの分離精製法としては, 横溝氏は 40 段の泡鐘 塔による蒸溜で結晶法と同程度の製品を得，金安氏ら はアジテーターによる强制冷却方式を用いて好結果を 得ている。ナフタリンの回収方法はガスを水のシャワ 一中を通ずる方式，活性炭で吸着する方法もある。ナ フタリンの精製には表面活性剂を用いる新方法もあ る。Szczepanik 氏はタールからのモフメチルナフタ リンの分離乃至応用について詳しく研究し, Coouradt 氏はメチルナフタリンの接触脱メチルによつてナフタ
リンを得る方法を研究している。文ール成分中の高級 な多環化合物は，タール溜分から分離するよりも合成 による方が簡単であるためか合成の研究が多い。たと えば保坂氏らの加圧下に打けるべンゼンからのジフ ニル合成や，ナフタセン，アントラセン同族体，ピレ ン, ベンゾヘリレン, 淡紅色の 6 環芳香族炭化水素" エトレンの合成などがある。粗アントラセンからのア ントラセン，カルバン゙ールなどの分離は従来より溶㓮 処理によるものが多く、トルェン処理,アセトン処理の 組合せ，1〜4 の㟶素を含むアルキル基をもつジェチ レングリコールのモノアルキルエーテルから結晶させ る方法などがあり，石油溜分よりシリカゲル，活性ア ルミナなどで吸着し，選択的脱着郕で脱着して多核芳 查族炭化水素を分離する方法も提出されている。利用 䀘究としてはBrooks 氏はフェナントレンを流動法て 酸化して無水フタル酸を製造し，功刀氏らはメチルナ フタリンを灯油湓化物々重合せしめてアルキルメチル ナフタリンとして浄洗荗原料とした。

タール酸 この部門に扎いては,フェフール類のタ ールからの回収方法の改良たとえば抽出方法, 新しい 抽出風の利用などが多く、また石油化学と関連して炭 化水素の酸化によるハイドロパーオキサイドの分解に よるフェノールの媻造の研究や特に廃水中のタール酸 の除去の研究は昨年に引続き多い。これに反しタール 酸の成分検萦は少なかつた, Randsepp 氏は頁岩タ ールのガソリン乃至ジーゼル油分のフェフール中に1ー および $2-\mathrm{C}_{10} \mathrm{H}_{7} \mathrm{OH}$ の存在を, Zavarin 氏らは一種 の杉の心材より $\mathrm{C}_{11} \mathrm{H}_{16} \mathrm{O}_{2}$ の 2 種のフェフール度得, Prasad 氏はインドの各種のタールについてタール酸 の量, 成分について調査している。フェフール類の分 離方法としては溶肪抽出が多く, 古崎氏らはキシレン スルフォン酸ソーダ $10 \%$ 水溶液を用いて岸化水素々 の混合物よりフェフールのみを抽出している。 Hess 氏は粗タール油をペンタンなどに溶解してへキサメチ レンテトラミンで処理してフェフール乃至キシレノー ル竞分離し，日比野氏らは管中を含酸油とソーが液を 並流に通して抽出してよい結果客得た。この外タール 炭化水素よりグリセリンなどでフェフール類を向流抽 出する方法も提出されている。またフェノールを含ん だ安水のベンゼン抽出, 第 4 級アンモニウム型陰イオ ン艾換樹脂による収着, 高温高圧の水による褐炭油中 のフェフールの抽出, 未蒸溜タールのヘンゼン溶夜か ら重曹飽和溶液によるカテニールの回収などがあり， フェフール類の分離回収に関する研究は曊る多い。ま たタール酸の成分々離としては, White 氏らは Celite 
535 劣用いて液体クロマトグラフによるmー扎よひ pークレン゙ールの分離を試み，その分離可能性を認め, またリグロイン・メタノールによる抽出，尿素附加に よる分離なども研究した。さらに2,4-および 2,5-キ シレフールをジイソブチレンでアルキル化しての分離 や，シリカゲルを吸着肪として芳香族酸の分配クロマ トグラフによる分離も試みられた。フェノール類の精 製は溶剤処理が多く，強塩基性陰イォン交換樹脂上を とおして含まれる脂肪族カルボン酸を除去した報告人 キサメチレンテトラアミンとペンタンを用いてチオ フェフールを除去した報告，粗ベンゼンで洗滌してタ ール酸ソーダ水溶液に溶解している中性油などを除去 した報告などもある。フェノール類の合成関係では， 炭化水素の酸化により製したハイドロパーオキサイド を分解する方法についての研究が頗る多い。この外ク レジール酸をイソブテンなどでアルキル化してブチル クレゾールとするアルキル化法，クレゾールなそ゚のメ チルエーテルを $\mathrm{POCl}_{3}$ の存在下でメチルフォルムア ミドでフォルミル化し，数段階を経てポリメチルクレ ゾールを得る報告がある。また Perna 氏らは褐宸及 ールの $230 \sim 70^{\circ} \mathrm{C}$ の エフール分を硫化バナジウ ムとタングステンを触媒として高温高圧でアンモニア を加え処理して低分子フェノールを得ている。この外 クレゾールのフリーデルクラフト区応により従来の文 献にない 3-イソプロビル 2-メチルフェフールをはじ め多くのイソプロピルクレゾールを合成した報告や，

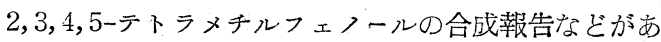
る。高木氏は石炭酸ソーダを電解によつてフェフール と苛維ソーダに分解するよう試みたが，フェフールの 酸化重合:よよて良い結果を得なかつた。またフェノ ールの酸化による酸化ジフェニールの合成, $m$ ークレゾ ールの接触異性化, 酸性油とアルカリ水溶液による赤 色物質の生成，またフェノール類による臭気について の研究などがある。タール工場の廃水ことにフェフー ル性廃水による河川の污染が近年問題となり，これに 関する研究がここ数年多い。吉田氏は発生炉がスの洗 涤水定研究し, 予め空気酸化した洗滌水觉业炭を濾材 として 85〜89\% のタール学除去している。この外洉 染についてはViehl, 宫永氏らの研究あり,フェノー ルの除去にはベンゼン抽出，オン゙ンによる酸化破壞， 弱塩基性イオン交換剤による吸着分離などの研究があ ๖。

タール塩基 近年報告の多かつた塩基に関するもの は逐次少くなり，殊に $\beta$-ピコリン溜分については， 直接の成分々離よりはむしろこれを酸化した後に分離
する方法が盛んに研究されてきた。また高級ピリジン 湓基については分離よりはむしろ合成研究の方が盛ん である。タール㷪基の成分検索として, Swietostawski 氏らはポーランド・コールタールの $157 \sim 9^{\circ} \mathrm{C}$, $160 \sim 7{ }^{\circ} \mathrm{C}$ 溜分よりそれぞれ 2,4-ルチジン，2,4,6-二 リジンを分離し, 軽油 $230 \sim 70^{\circ} \mathrm{C}$ 分を精溜してキノリ ン，イソキノリン，8-メチルキノリンなどを分離し， 地福氏らはキフリン溜分の $210 〜 225^{\circ} \mathrm{C}$ 溜分をアセチ ル化した後に分離を行つてキシリジンを確認した。 異性体の分離は一時盛んであつたが，本年度では Coulson がルチジン混合物よりフェフールと複化合物を 作つて2,5-ルチジンを冷却結晶法で分離しているのが 目に止る位である。しかし酸化したのちの分離法とし

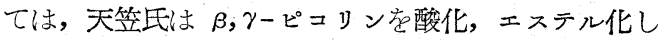
たものから液体アンモニアによるアミド化の差を利用 して両者の酸アミドを分離し, 山本氏らは水, 石油エー テル, ベンゼンの混合物または水ーブタノールなとによ りそれぞれニコチン酸とイソニコチン酸のメチルエス テルまたはニコチン酸とイソニコチン酸の液-液抽出 によつて分離を試みている。ピリジン塩基は高級とな るに往いタール塩基よりの分離が困難で，むしろ合成 で得られる場合が多いが，近年ピリジンなどの低級睢 基の合成も試みられるようになつてきた，すなわちア

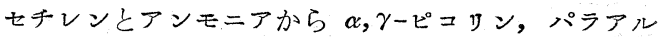
デとドとアンモニアから 2-メチル 5-エチルピリジン アセトアルデセドとアンモニアよりピリジン，ピュリ ンなどの合成のように Skraupの反応やこれの改良法 が多く，またピロール類,インドール類の合成もあるが これは Knorr 反応によるものが多い。タール㷪基の 酸化はニコチン酸，イソニコチン酸を目的としたもの が多いが，その方法は雑多である。Lidak 氏らは 10 〜20\%の $\gamma$ ーピコทンを含も $\beta$-ピコリン溜分をホル マリンと縮合し，水蒸気蒸気蒸溜した残りを硝酸々化 してイソニコチン酸を得ている。Swietostawski氏は

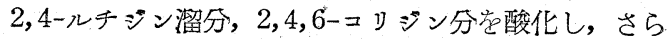
に脱炭酸して理論值の $50 \%$ 以上のイソニコチン酸を 得ている。Herring 氏は 2,5-ジアルキルピリジンを 加圧下で硝酸々゙化し，イソシンコメロン酸を得た。こ の外 $2,2^{\prime}$-ジピリジルの合成法としてピコリン酸銅の 熱分解, またはサイメン，銅粉末，ブロモピリジンなど からの合成が報告された。Mosher 氏はピリジンに醋 酸を加え, 塩化水素に通大し, 真空管中で攪汼しつつ イソプロピルアルンールを加えて 76〜83\% の収率で ピリジン $N$-オキサイドを得ている。この外利用研究 として酸蝕抑制荗，秀れた還元剤であるピリジンボラ 
ン $\left(\mathrm{C}_{5} \mathrm{H}_{5} \mathrm{NBH}_{3}\right)$ の製造, 気相塩素化, ピロール類の メタレーション，色素，水銀化合物の簡単な製造法な そ，多くの研究がある。

ピ.ッチピッチに関する研究のうち，ピッチ成分の 検索は長年続けられているが，その他の研究は報告が 少い。Gundermann 氏は各種溶解度の差によつて褐 炭タールピッチの組成を大別し, Kruber 氏等は 400

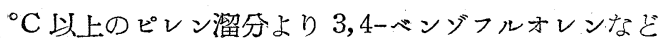
5 種の化合物を新たに分離確認した。Wood 氏らは市 販ピッチ, 空気吹込ピッチ, 直溜歴青について溶㓣抽 出, 再結晶によつて組成一分子量について考察し,

Briggs 氏らはと゚ッチの熱伝導度測定装置を作つて多 くのピッチにつき熱伝導度を測定し，神岡氏らは空気 吹込によつて軟化点の上昇度を検钨し，三宅氏はピッ チの連続冷却装置についてのへ, Wallace 氏は 0.25 〜2.5\% の軟質石油ワックスのエマルションを被覆し て無刺戲性のピッチを得ている。

分析 従来の化学的な分析法の改良の外にクロマト グラフ, 吸収スペクトルのような物理的方法を利用し 今まで分析の困難であつたものを迅速かつ精確に分析 できるようになつてきた。中性油関係の分析について は，少量のベンゼン，トルエンなどを定量するのに硝 化によつて得たニトロ化合物のアセトンとアルカリに よる呈色を利用する方法, トルェンベンゼン混合物の 蒸溜によるトルエン量の簡易推定法, ベンゼン類中の 硫黄定量に白金一シリカ触媒を用いたウィルソン法, キサントグン酸エチルとモリブデン塩を利用する二硫 化炭素の比色定量法, または硫酸第二鉄の存在で二硫 化炭素とイサチンを反応せしめて比色定量する方法等 の研究がある。シクロペンタジェンの定量法として, 鈴木氏は無水マレイン酸との附加反応を利用し, Shǔkin 氏は硫酸中の鉄明䙪を用いて検出し，また武内氏 らは赤外吸収スペクトルを用いて定量し，さらに時閒 的変化についても追求している。磯部氏らはタール酸 中に混在する中性油分を光霞比色計による濁度の測定 によつて定量し，Yurko 氏はシリリカゲルを用いてべ ンゼン乃至 $p$-キシレン，エチルベンゼンをクロマト グラフにより分離している。ナフタリンについては， Carleton 氏は融点曲線によつて不純物を定量し，田 中氏らはピクラートの生成反応を利用してガス中のナ フタリンを，また Schubert 法によつて洗湘油中のナ フタリンを定量している。その他, 多環炭化水素の分 析については, Chanmann 氏は蒸溜, クロマトグラ フによつて頁岩油中のベンゾ $[\alpha]$ と゚レンを定量し， Tye 氏は同物質をヨード化して紫外部吸収によつて
定量し，また Bowen 氏はコロネンを溶郕に溶かし罃 光スペクトルで定量した。カルバゾール中のアントラ センを吉田氏らは光電光度計で定量し，また船久保氏 らは無水マレイン酸を用いるアントラセンの定量につ いてクロルベンゼン法, キシレン法, ジオキサン法な ぞを比較し，詳細な報告を発表した。フェノール類の 分析については非常に多くの方法が提出されているが そのうちの数例をあげれば，莫素化して酸化還元電位 の測定によるもの，臭素化の際の反応性の相違を利用 したもの，クロマトグラフの利用，ベーパークロマト グラフの利用などがあり，鏑木氏は稀薄フェノールの 定量法を比較し, Mesnard 氏らは硫酸銅を含む稀重 曹溶液中の過酸化水素て酸化し，各フェフール同族体 について特有の呈色が示されることを利用して定性分 析を行つた。クレン゙ールの成分々析については, Whehle 氏らは酸化してフロログルシンで赤色に呈色 する方法によつて カゲルで分離し，2,6-ジブロモベンゾキノンで着色物 質を作る方沠で o-, $m-, p-$ クレン゙ール，フェノールの 定量を行つている。Stoltenberg 氏はクレゾール中の のークレゾールを $p$-ニトロアニリンジアゾニウム塩と カップルさせ，クロルベンゼンで抽出してクロマトが ラフで分離定量し，Soloway 氏らはパラ位に置換基 のないフェノールの検出にアンモニア水溶液中で銀イ オンの存在下に過硫酸イオンにより酸化呈色せしめる 方法を用いている。タール塩基の分析としては, 武者 上はチォシアン酸の生成を利用してピリジンを容量分 析し，舟坂氏らはペーパークロマトグラフでピリジン

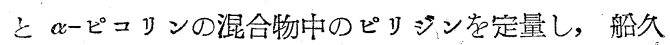
保氏らはタール醏基第二銅塩の二色性について述へて いる。この外，定量には赤外並に紫外部吸収スペクト ルを利用したものが多く，田中氏らは分溜コリジンよ り多量のアニリンを認め,またピリジン類以外にもキ フリンイイソキフリンの分析にも吸収スペクトルの利 用の研究がある。

このほかコークス炉ガス中の青酸の分析, フェニー ルフルオロンによる安水中のゲルマニウムの分析, そ の他、粗無水フタル酸中のフタル酸定量, 流水中の心゙ ンゼンの定量, 2,2 2'ジピリジルのポーラログラフィ 一タール中の水分の定量など，分析に関方る研究は 頗る多い。

以上の外，タール中に確認された物質の一括表示や 物理恒数の測定にも相変らず努力が続けられている。 またタールそのものの利用法としても Nail 氏队恩田 氏の木タールの利用研究も市り，一方 Reynolds 氏 
のタール脱水に温度王力をかけて静置する方法どの研 究もある。タール蒸溜装置については田中氏, 池村氏 らの実際の設備による報告や小島氏らのガス軽油の蒸 溜についてのホールドアップと還流比の相関々係につ いての報告むある。このような蒸溜装置に関方る研究 は多いが，ことに計測管理，自動制御が盛になり，及 一ル蒸溜にこれらの応用に関する研究が多い。また精 溜塔の改良, 蒸溜方法の改良, 共滞蒸溜などの研究が ある。タール関係物質の回収方法として溝口氏は精溜 廃油を酸化モリブデンを触媒として水添分解して低沸 点分を得ているし，佐伯氏はコークス炬がス中のシア ンをロダンアンモンとして回収する方法をのへ，結晶 を得るため加熱空気吹込法について研究し，また洗涤 水より重炭酸アンモン回収法の研究やOtto 氏のコー クス炉ガスよりのアンモニア回収に減圧を用いたもの もある。ガス脱硫方法としてはボーキサイトをアルカ リと化合せしめたものを用いる方法，鉄またはマンガ ンの酸化物で $150 \sim 170^{\circ} \mathrm{C}$ で流動法による方法，酸性 察永で洗滌する方法などが提案されている。この外ナ フタリンなどの酸化用触媒, タール堌産の方法, ター ルなどの水素添加, 合成樹脂などへの利用, タール成 分による職業病，中毒に関する報告などがみられた。

\section{都市ガスエ業の趨勢}

炤和 30 年( 1 月〜 12月)の都市ガス工業は前年に引! 一続き活況を呈し，全がス供給量におおいて前年に比し約 11\% の増加を示し, 約 23 億 $\mathrm{m}^{3}$ に達した。

第12表は昨年 1 カ年の都市がス工業の全貌である。

\section{第12表 昭和 30 年 (1955) のガスエ業統計}

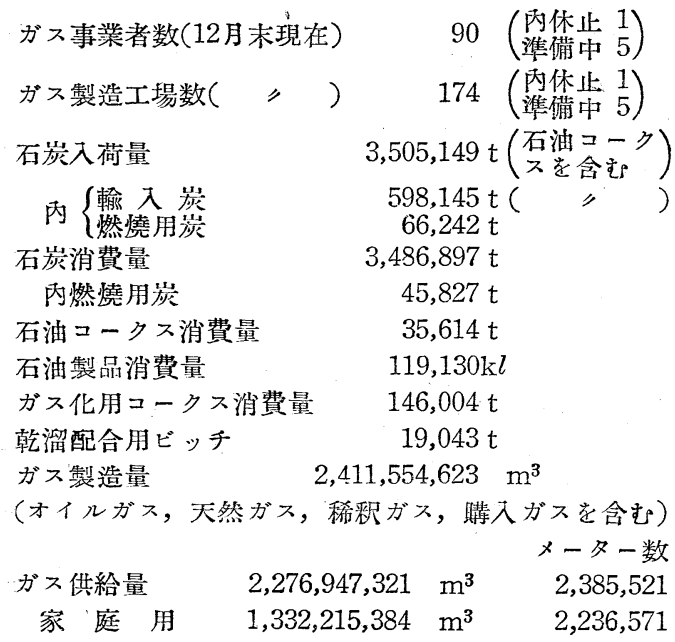

$\begin{array}{crrr}\text { 工 業 用 } & 372,490,832 \mathrm{~m}^{3} & 20,528 \\ \text { 商 業 用 } & 396,332,272 \mathrm{~m}_{\varepsilon} & 102,363 \\ \text { その他用 } & 175,908,833 \mathrm{~m}^{3} & 26,059 \\ \text { 自家用ガス } & 52,522,458 \mathrm{~m}^{3} & \\ \text { 內 烸 㘿 用 } & 40,654,510 \mathrm{~m}^{3} & \\ \text { 勘定外ガス } & 81,939,253 \mathrm{~m}^{3} & \\ \text { コークス生産量 } & 2,375,925 \mathrm{t} \\ \text { コークス販壳量 } & 1,702,387 \mathrm{t} \\ \text { タール生産量 } & 215,994 \mathrm{t} \\ \text { 内 石油タール } & 31,884 \mathrm{t} \\ \text { ベンゾール生産量 } & 13,725 \mathrm{t} \\ \text { 硫安生産量 } & 26,833 \mathrm{t}\end{array}$

昨年中ガス工業で特筆すべきものに次のようなもの がある。

\section{(1) ガス事業 5 力年計画の改訂}

昭和 28 年 5 月作られたガス拡充 5 カ年計画は 2 年 を経過し，その間がス供給量は計画を少しく上迴る成 績を示し, 需要家数も大体計画通りに推移したが, コ ークスの市洁は初め考えたほど思わしくはなく，今後 も急速な好転を望み難いとして,この 5 カ年計画は将 来の分について多少の改訂が行なわれ，最終年たる昭 和 32 年度において需要家数，供給がス量とも $5 \%$ 程 度増加させたが，コークス生産量は原計画の約 $86 \%$ となるように石炭の乾溜量を減ずる代りにオイルガ ス，増蓺水性ガスの製造量を増すこととし，また石炭 の完全がス化法も取り大れることとしたことが注目に 洒する。

\section{（2）都市ガス増強の動き}

1 作年国会の要望に基き “木材利用合理化方策連絡 協議会” が設監され，木材資源利用合理化方策の一と して都甫がスの普及向上が必要と認められ，“都市が ス拡充促進協議会”が 29 年末に発足した。木材資源 利用合理化方策ば 1 月 21 日閣議決定となり, 民間に “木材資源利用合理化推進本部”が，また経済審議庁 には“木材資源利用合理化協議会”が4月 1 日に設置 され，前記 “都方がス拡充促進協議会”は推進本部の “ガス部会”として再出発することとなつた。

一方政府は“土ネルキ総合対策”を立案し，5月閣 議で了解され，都市ガスの進むべき道を示した。

(3) 新堌設工事

ガスの需要増加に従い, 各所でガス製造設備の新増 設が行なわれたが，そのうち特筆すへきものに次のよ うなものがある。

大阪がス，岩崎工場 PGC 式増蓺水性がス装置 4 基 新設 $\left(150,000 \mathrm{~m}^{3} /\right.$ 日/基)

東邦ガス, 桜田工場 PGC 式増熱水性ガス装犆 1 基 増設 $\left(100,000 \mathrm{~m}^{3} /\right.$ 日/基) 
広島ガス, 広島工場 H\&G 式増熱水性がス装置 1 基 新設 $\left(30,000 \mathrm{~m}^{3} /\right.$ 日/基)

静岡ガス, 沼津工場 PGC 式㦈熱水性ガス装置 2 基 新設 $\left(10,000 \mathrm{~m}^{3} /\right.$ 日/基)

なお東京ガスはその世田谷整圧所に高圧球型がス溜 2 基 $\left(5 \mathrm{~kg} / \mathrm{cm}^{2}, 20,000 \mathrm{~m}^{3}\right.$ 容積/基)の建設に着手した。

(4) 新が ス事業の発足

昨年中に新たにガス事業の許可を受けたものと，営 業を開始したものは次のとおりである。

事業許可

30. 9.12 秋田県金浦町(町営)

30. 9.12 大分県中津市(市営)

30.10.30 山梨県都留求(谷村がス K.K.)

営業開始

30. 2 青森ガスK.K.(青森県)

20. 4 佐野がスK.K.(栃木県)

30.9 北見市営がス(北海道)

30. 9 富士宮がスK.K.(静岡県)

30.11 福知山芇営ガス(京都府)

\section{ガス化エ業の勢䘽}

他の項目との重複を避けるために，本項目の範囲常 アンモニア，メタノール，その他の合成原料ガスを製 造するガス化工業に限定し, その範围において石油, メタン, ニークス抢よび石炭の 4 種原料について内外 の趨勢を述へる。

1. 石油

1 重油ガス化

日産化学富山工場においては,イタリー Montecatini 社からの挬術遵大による Fauser式重油がス化製 造装置が 9 月末に完成し，10 月初から順調な操業に はいつている。本装置はガ六発生量 $4,000 \mathrm{~m}^{3} / \mathrm{hr}\left(\mathrm{NH}_{3}\right.$ $1.5 \mathrm{t} / \mathrm{hr}$ ) の能力で, 既設 Winkler 炉との組合せ操業 によつて妙味を発揮している。東海硫安四日市工場に おいても同しく Fauser 法套導大して発生がス量 600 $\mathrm{m}^{3} / \mathrm{hr}$ のパイロット装置を 7 月に完成し, 锺々の試験 定行なつており,一方 $5,000 \mathrm{~m}^{3} / \mathrm{hr}$ 本装置を年末から 31 年初頭にかけて完成方る予定である。その他新日 本窒素水俣工場では能力 $4,000 \mathrm{~m}^{3} / \mathrm{hr}$ の同じく Fauser 式装置を建設中である。本法は有效水素合量 82 83\% のガスを発生し,炭素效率 95\% 以上でガス原価も安く 有利であるが，米国ではたとえば Texaco 法のように 同一の装置で天然ガスと重油とを簡単に切換使用でき るガス化装置の発達によつて，たとえば冬期天然ガス
の一般需要が伸びれば重油を使用するなど，市況の変 動に応じて天然がスこ切換使用する重油がス化法が最 近急速に発達している。この装置は加圧がス化法であ つてコンパクトな特徴がある。また消費地に近接して 工場觉譤訢し得る立地上の有利性から重油專用の工場 も次第に増加しており，9 月現在建設中のもの 4 カ所， 能力計 $\mathrm{NH}_{3} 510 \mathrm{t} /$ 日 (プェルトリコ,メキシコ, 西欧を 含も)，また契約成立のもの 4 力所，能力計 $\mathrm{NH}_{3} 785$ $\mathrm{t} /$ 日（カナダ, 英国, 韓国を含む）に達している1)。

口石油廃がス

わが国でも石油改質分解装置が次々に连設されたが 廃がスを合成原料がスとして考光るにはいずれも規模 が小さい点に困難が多いようである。欧洲でもわが国 と同じような傾向がみられるが，米国では石油精製工 場の㚘模が大きいので, 廃がスの利用面では合成アン モニアが最も大きく，米国内の 52 の合成アンモニア 工場のうち 5 工場は石油精製工場内にあるほどで，米 国の合成アンモニア工業の拡張が現在の割合で続けば 間もなく生産過剩になることが予想されるが，その場 合でも石油工業廃がスを利用する合成アンモニア工業: は需要供給の面とは関係なく低コストの故に既設のア ンモニア工業と競争して引続き発展することが推測で きる2。

なお，わが国でも各社の石油化学企業訐画がいよい よ具体化して寒現の段階に入つてきたが，アンモニア 合成工業と組合せて相互の合理化に妙味を求めるもの が多い。すなわち所期の石油化学製品を得た後の分解 残がス蒿アンモニア源とするもので，たとえば三井石 油化学岩国工場では土チレン誘導体フェフール，ア セトンなどとともに，硫安 $58,000 \mathrm{t} /$ 年, 尿素 $27,000 \mathrm{t}$ /年 $\left(\mathrm{NH}_{3}\right.$ 換算訐約 $32,000 \mathrm{t} /$ 年) の生産を訫画してお り, 三菱石油化学四日市工場ではスチレンモノマー, エチレン誘導体, プロピレン誘導体，テレフタール酸 などとともに硫安 $80,000 \mathrm{t} /$ 年 $\left(\mathrm{NH}_{3}\right.$ 換算約 $22,000 \mathrm{t} /$ 年 $)$ を, また住友化学新居浜工場ではエチンンと共にアン モニア 32,000 t/年をそれぞれ計画している。

2. メタン

1 天然ガス

わが国では新潟地区の乾性ガス $\left(\mathrm{CH}_{4} 95 \%\right)$ は，推 定埋蔵量約 300 億 $\mathrm{m}^{3}$ に対して既開発利用量汃約 3 億 $\mathrm{m}^{3}$ であつて本格的開発利用は今後の間題である。 日本ガス化学新潟工場は Kauper炉によつて熱分解し てメタノールを製造しているが，ガス原価は同業他社 に比して格段に低いようである。同社では秋から従来 1,000t/月の能力であつたメタ>ール製造設備を 1,800 
$\mathrm{t} /$ 月に拡張し,さらに米国 C.C.C. 社よりの技術導大 による能力 $30,000 \mathrm{t} /$ 年のアンモニア製造設備新設計画 もすでに建設の段階に入つている。この計画はアンモ ニアを尿素抢よび硫安にしようとするもので，原料天 然ガスは硫黄分少く化学工業原料として最も優秀なも のであり，また接術導入により既設の Kauper 师に よる熱分解に比して分解効率も上昇するから，ガスコ ストの面で同業各社に対して充分優位の競争力をるつ ものと推測される。他に秋田地区の湿性ガスについて も種々の開発利用計画があるようであるが，穾現には 埋蔵量抢よび今後の開発が問題であろう。然料として 使用した場合は， $1 \mathrm{~m}^{3}$ のメタンは約 $1.5 \mathrm{~kg}$ の石炭に 相当军るが，アンモニア合成原料として考えると $1 \mathrm{~m}^{3}$ のメタンは燃料用も含めて $2.5 \mathrm{~m}^{3}$ の水素に相当し,一 方 $1 \mathrm{~kg}$ の石孷は $1 \mathrm{~m}^{3}$ の水素を生産するのみで，この 面からは $1 \mathrm{~m}^{3}$ のメタンは約 $2.5 \mathrm{~kg}$ の石炭に相当する ことになり，採算的に非常に有利となるので，諸外国 においても天然がスの合成ガス原料としての開発利用 は戦後急速な発展をとけた。特に米国抢よでイタリー に抢いて著しく,“米国ではアンモニア全生産量の $80 \%$ を占めており，イタリーでは国策として政府が積極的 に開発をすすめ, 価格面でも化学工業原料としての使 用に有利なように操作されているが、なお高税のため に米国に比して約 5 倍の価格になつており，それでも

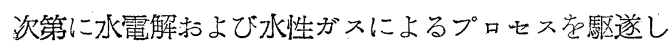
ている。天然がスから合成原料がスを得る方法として， 以前は単なる熱分解法が行なわれていたのに対して，

現在では多くの工場がメタン水蒸汽接触区応を利用し ており,さらに最近の傾向としてその加圧法や酸素を 用いる部分燃佬法またはとの組合せによる方法が採用 されている374)5)。

$$
\text { ロコークス炬がス }
$$

従来, 合成原料がスとして考える場合には，深冷分 離によつてメタンを除く方法が考えられていたが，三 菱化成黒崎工場では, イタリー Montecatini 社から の技術導大による Fauser 法メタン分解装置を 6 月な かはから着工し，31 年早々に完成する予定である。同 法によつて約 30\% のメタンを合んだコークス炬がス を植接分解してアンモニア原料がスとする計画で，既 設の Winkler 炬との併用により,アンモニアの能力 堌強合理化をはかつている。またわが国では鉄鋼業の 副産コークス炬がスは単に然料として消費されている 現状でありこれを合成原料がスとして利用すること は末だ実現されていないが，酸素製鋼の採用などと関 連してコークス炬がスの有効利用がようやく考慮され
るようになつてきた。

$$
\text { 3. ニークス }
$$

\section{1 酸素水性がス炉}

従来一般に採用されている水性がス法は切撸操業を 行う間歇式なので, 別府化学別府工場では水性炉に酸 素を吹込み，連続的に合成がスを製造してガス化率を 向上してガスのコストを低下することを訫画し, 酸素 装置の増強など一連の設㣁を年内に完成する予定であ る。

\section{4. 石崖}

ドイッ Koppers 社よりの技術道大による日本水素 小名浜工場の粉孷がス化装置は業界の注目を浴びて 9 月 1 日に火大式を挙行し, その後試運転を経て現在順 調に 3 基操業中である。4,100kcal $/ \mathrm{kg}$ の石炭を用いて 1 基当り当初計画 $\left(3,400 \mathrm{~m}^{3} / \mathrm{hr}\right.$ ) 存上迴る $3,500 \mathrm{~m}^{3} / \mathrm{hr}$ ガス范発生し，また有效水素濃度 84.3〜84.5\%，メタ ン含有量 $0.01 \%$ ，有機硫黄含有量ほ之んど分解などの 数字もほとんど計画どおりで, 装置計器などの器機の 運転状況も順調といわれる6)。

宇部地区，北九州地区などの石炭産出地帯に近い各 社も同法の採用について積極的に考慮している如くで ある。また米国 Olin Mathieson 社 Morgantown 工 場では Texaco 法による粉炭ガス化中間工場の建設を 決定した。建設には8 カ月を要する見込みで，その運 転結果によつて7) 現行の水性炉を逐次置きかえて行く 方針である。また原子力を用いて粉㟶をガス化する計 画も同しく米国に抢いて次第に具体化してきているよ うである。原子力委員会と鉣山局とは共同で Morgantown で B-M リアクターと称する訫画を進めている が，2,000 3,000F で運転される原子炉ができれぱ その中を通過する管の中に粉炭と蒸汽とを加圧下に通 じてがス化しょうとするもので，現在の酸素を用いる 方法に比して 45〜60\% の低コストで原料がスが得ら れるという。適当な管の材料を得ることが困難な問題 であるが, 高温安定性, 伝熱性, 放射能耐性, 融灰の 侵蝕に対する抵抗性, ガスの透過性などの点からシリ コンカーバイドが現在考えられている8 。

\section{交献}

1) The Oil \& Gas J., Sept. 19, 80 (1955).

2) Petrolewm Processing, Aug. 1164 1165 (1955).

3) Ohem. Eng. Prog., Sep., 418 421. (1955).

4) Ohemie Ingenieur Technik, Sep.,465 469 (1955).

5) Petrolum Press Service, Aug. 296 297 (1955).

6) 肥料誌， 14, 13〜15 (1955). 
7) The Morgantown Post, July 7, (1955).

8) Chem Week, A pril 23,92 (1995).

\section{分ス化に関する研究}

東京大学矢木栄氏, 国井大蔵氏, 日東化学池田米一 氏，鐘淵化学鉷田太一氏はガス化装置の性能に関する 研究1),2) という題で合成原料がス製造に打いてェンタ ルピ収交を基礎とする熱力学的研究を行い, 有効がス $\left(\mathrm{CO}+\mathrm{H}_{2}\right)$ 発生量と酸素消費量に関する理論式を誘導 し,これらの式を用いて実際の工業的なガス化データ を解析し，コークスや石炭を原料之する充填層型，流 動層型, 気流反応型の各種がス化装置にも重油ガス化 装置にも適用できること榷めた。また矢木栄氏(3),4)， 5) らは粉コークスを流動層でガス化して発生师がスを つくる場合, 総括反応速度䋆数が粒子の集合, 粒径, 層高, 流速などによつて如何に変化するかを理論的な らびに実験的に研究した。

石炭化学掕術懇談会の答申書6) (石炭化学工業の振 興に関する意見）には今後にお打る完全ガス化㚘によ る都市ガスならびに合成原料ガスの製造, 或は硬炭が ス化によるガスタービン用ガスの製造の重要性が大き く採り上げられていて，事実都市がス工業や硫安工業 の各社では経営合理化の重要な一環としてこのような 線に沿つて新しいがス化方法の採用に努めていること はよく知られているところであるが，新しいがス化方 法を綜説または紹介した文献には次のようなものがあ つた。下村明氏「石炭完全がス化の発展と将来」》近 藤礼一氏「油がス化について $]^{8)}$ ，馬場有政氏」石炭の ガス化 $]^{93}$, 照井秋生氏「石炭の原料がス化について」10> 「最近のガス化法の発展」(1)，相原弘氏「最近のガス発 生师」12) では New Wellman-Galusha ガス発生炉が 紹介されており，別府次郎氏「PGC 式増熱水性ガス 発生装置について」には最近の PGC 式が紹介されて いる。佐藤恒已氏 ${ }^{14)}$ は製銑副産ガスを合成原料ガスど して或は都市ガスとして利用し，製鉄工業と肥料工業 都市がス工業とを綜合関連させることの䨘要性を説い た。

硬炭ガス化については現在九州電力ならびに資源技 術試験所が研究中であり, 電力中央研究所を幹事とす るガスタービン愁談会ではオープンサイクルガスター ビンと硬炭ガス化炉を組合せた発電のパイロットプラ ントに関する具体案を作製推進している。

地下ガス化 15),16)については国連エカッフェならび に技術協力局から派遣されたり連視察団がアジアに打
いても地下ガス化試験を行う必要のあることを鹳告 し，その結果ェカッフェ当局はさらに試験の实施を日 本政府に依頼してきたため，日本としては引受ける可 きかぞうか専門委員会を設けて検討中である。ソ連は 地下ガス化の草分けで戦前すでに工業化の段階に到達 していたといわれるが，戦争のため中断され最近に至 つて試験を再開しておりり苚，英国 ${ }^{18}$ 抢よび米国では戦 後着手した大规模な勍験を新しい技術を発展させなが ら続行しており，両国共地下電気乾溜の工程を合さ地 下ガス化法19)に大きな関心を示している。英国では17) 地下ガス化によつて得たガスでガスタービン発電を行 えば現在の火力発電以下のコストて電力を供給できる 可能性があると推測しているが，種々の技術的冒険の 要素を含む㔠験なためか各国とも政府機関が主体とな つて跔験を行つている。

海外交献中ガス化反応に関する基礎的なものには IEC にはガス化の反応機構炎研究した C.W. Zielke 20)の報告や孷素々水蒸気の民応機構苑研究した J.M. Pilcher 氏 21) らや㟶素と水蒸気の反応に対する金属 酸化物の接触的影響の Tuddenhaum ${ }^{22)}$ らの報告があ る。J. Phys. Chem.には炭素と炭酸がスの反応”3)や 孷素々酸素の反応 ${ }^{24)}$ に関するChen らの研究がある。 Fuel の P. L. Walker 氏の報告25)はガス化のX線廻 析による研究であり, Brenn. Chem.のS. Transtzel の報告26)はガス化の機構に関するものである。えの他 Stahl u. Eisen"7) には高炉中の $\mathrm{C}+\mathrm{CO}_{2}$ の平衡反応 に関するものがあり，印度の J. Sci. \& Ind. Research の P. S. Murthy 氏の報告28》は流動層における 固体然粦ガス化の反応に関するものである。

H. R. Batchelder 氏らの報告29)は米国 Bureau of mines が Missouri 州 Louisiana の実験工場て行つ た㹂型の微粉炭がス化炉の成績で，Koppers-Totzek 法のように石炭を子小酸素と混合して送る代りに石炭 を過熱水蒸気で運搬し，2本のバーナ直前て酸素を混 合して成功した。Lurgi 式加圧ガス化に関しては英国 炭による中間試験の結果 30),32) やオーストラリヤの大 規模工場の成績 31 が発表された。油がス化については 綜説的な紹介が多数 $\left.\left.\left.{ }^{33)}, 34\right), 35\right), 36\right), 37$ ) 発表されたが，英 国 South-Eastern Gas Board が研究した Segas 法 は重油老触媒の存在下に分解して瓦斯組成, 比重, 発熱 量などが都市ガスとほとんど变りのないがスを得る方 法である。その他ガス発生炉の発展を概説した G. W. C. Allan 氏の報告39) や水性ガスに関する J. Burns 氏の報告40がある。また Wellman-Galusha 発生师の 成績空示した J.A. Grainger 氏の報告がある。 


\section{文献}

1）矢木栄，国井大蔵，池田米一，鎌田太一, 燃協誌, 34, 426 (1955).

2) 国井大蔵，樊管理，7，9 月，10 (1955).

3) 矢木栄外, 燃牊誌, 35, 32 (1956).

4) 矢木栄外, 化学工学, 19, 401 (1955).

5) 矢木栄外; 化学工学, 19,500 (1955).

6) 石炭化学技術懇談会, 昭利30年12月26日.

7) 下村明，燃協誌， 34，481 (1955).

8) 近藤礼一, 化学工学, 19, 73 (1955).

9）馬場有政，化学工業，6,222 (1955).

10) 照非秋生, 化学工業, 6, 993 (1955).

11) 同, 熱管理, 7, 1 月, 30 (1955).

12) 桐原弘, 化学工業, 6, 155 (1955).

13) 別府次郎, 産業機㭜 No. 54 月, 13 (1955).

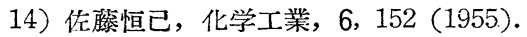

15）馬場有政，䙪管理，7，6月，2 (1955).

16) A. Wunderlich, Bergbai Rundschau, 7, Mar., 119 (1955).

17) Bergbau Tech., 5, 484 (1955).

18) British Trials in Underground Gasification 1949 1955, Ministry of Fuel and Power.

19) E. Sarapun, 英国特許 725, 675 .

20) C. W. Zielke et al., Ind. Eng. Chem., 47, 820 (1955).

21) J. M. Pilcher et al., Ind. Eng. Chem., 47, 14 72 (1955).

22) W. M. Tuddenhaum, et al., Ind. Eng. Ohem., 47, 2129 (1955).

23) Chen et al., J. Phys. Chem., 59, 241 (1955).

24) Chen et al., J. Phys. Chem., 59, 1146 (1955).

25) P. L. Walker, Fuel, 34, 22 (1955).

26) S. Traustzel, Brenn. Chem., 36, 181 (1955).

27) Staht $u$. Eisen, 75, 1582 (1955).

28) P. S. Murthy \& A. K. Das Gupta, J. Sci.

\& Ind. Research, 14B, Apr., 174 (1955).

29) H. R. Batchelder \& L. L. Hirst, Ind. Eng.

Ohem., 47,1522 (1955).

30) Coke and Gas, 17, 10 (1955).

31) Andrews, Eröl u. Kohle, 8, 703 (1955).

32) Coke \& Gas, 17, 188 (1955).

33) Gas World, 141, 83 (1955).

34) Gas World, 141, 707 (1955).

35) Gas World, 141, 772 (1955).

36) Gas World, 141, 1065 (1955).

37) F. Leithe, Eröl u. Kohle, 8, 546 (1955).

38) G. W. C. Allan, J. Inst. Friel, 28, 458(1955).

39) G. W. C. Allan J. Inst. Fuel, 28, 458 (1955).

40) J. Burns, Coke \& Gas, 17, 173 (1955).

41) T. A. Grainger, J. Inst. Fuel, 28, 594 (1955).

\section{天然分ス利用の趨勢}

昭和 30 年度の天然がス利用に関し特に目新らしい
事項はみられない。世界の主要天然がス生産国の事情 を概観するに米国に打ける生産量は 2 億 3,500 万t, 全 エネルデの $25 \%$ を占める巨大なものであるが, 天然 ガスの工業的利用の発展は幾分その歩調が湲かになつ たように思われる。戦後アンモニアおよびメタノール の合成原料は急速にコークスから天然がスに転換され たが，昨年建設された工場で石油精製副生がスおよび C重油安使用するものが現われた1)。またーボンブラ ック工場の閉鎖抢よひ原料を石油に転換するものが続 出したが，これらはいずれも天然がスの生産の増加が 需要の増加に追附かずガスの価額が騰貴したため々み られている2。現在米国に抢けるアンモニアの合成能 力 370 万 $\mathrm{t}$ の中 $87 \%$, メタノールの $495,000 \mathrm{t}$ の中 64 \%は天然がスを原料えしている。天然がスより Andrussow 法による青酸の合成も数社で行われ，その大 部分はメタアクリルェステルおよびアクリロニトリル の原料として使用されている。アクリロニトリルの生 産額は数万 $\mathrm{t}$ を超えるもの亡推定される。アクリロニ トリルの一方の原料であるアセチレンはまたビニル化 合物の原料としても重要であるが，これは Monsanto, Carbide \& Carbon, 抽ひ American Cyanamid の 3 社においてメタンの酸素による不完全燃焼法によ つて一昨年から製造を開始しておりその後变化はない ようである。メタンの塩素化物を生産しているのは 7 社あり, 塩化メチレンより四睢化炭素に至る 4 種の㷪 化物の生産量は凡そ 15,000t である3)。

伊太利の天然ガスの生産額は 1954 年度 30 億 $\mathrm{m}^{3}$ に達したがその後はさらに謃しく増加しだものと思わ れる。その生産地 Po 河溪谷と北伊太利の大部分の都 市は 4,000km およびパイプラインで連絡されている。 この国の天然ガスの開発の経緯は今春ローマで開催さ れた第 4 回世界石油会議で報告された4)。孷素資源の 乏しい同国では天然ガスは原料およびェネルギ源とし て重要な役割を果しているが，アンモニア，メタノー ルの大部分は天然ガスを原料として製造され酸素によ るメタンの不完全燃焼法によるアセチレンの製造も 3 工場で実施され醋酸などの原料として使用されている ことが同会議で報告された5)。Andrussow 法による青 酸の合成も実施されている。

西ドイツにおける天然ガスの生産量は 1954 年 15, 000 万 $\mathrm{m}^{3}$.であつたが 1955 年はさらに数十\%は増加 していることはほとんど確実である。その中相当の部 分がアセチレンその他の化学製品の原料として使用さ れているものと想像される6)。

フランスの天然ガスの生産量は 1954 年 2,600 万 $\mathrm{m}^{3}$ 
であつた。その後新しい鉣区が確認されているが開発 に着手していない。それは硫黄分が特に多いためであ るが，硫黄の回収によつて充分採算可能とみられてお り近く開発に着手されるものとみられている。近年石 油および天然ガスの事業に関心が払われるにに至つた のでヨーロッパに扢りる重要生産国となるものと推定 されるす。

本邦の天然无スの埋蔵量は昭和 27 年東京通産局の 調査によれば北海道, 関東, 東北, 北陸諸県にわたり 石油系抢よび氷溶性のものを合算し 2,440 億 $\mathrm{m}^{3}$ と推 定されている。昭和 29 年度の生産量は 113,856 (千 $\left.\mathrm{m}^{3}\right)$ であつた ${ }^{8)}$ 。昭和 30 年度の生産量は未だ発表さ れていないが恐らく 150,000 (千 $\left.\mathrm{m}^{3}\right)$ に達するものと 思われる。その中石油系のものは $20 \%$ ，水溶性のもの は 80\% で，後者の中で新潟県は全体の $60 \%$ 老生産 する。その亦地は信濃川抢よび阿賀野川下流のデルタ 地帯すなわち新舄市周辺であつて, 都市がス, 工場燃 料捛よび自動車用然料として消費されている。昭和 27 年よりこのガスを原料としてッタノールの合成を開始 した日本瓦斯化学工業株式会社は年末にその能力を月 産 $2,000 \mathrm{t}$ に拡大した。これがため 1 日約 $100,000 \mathrm{~m}^{3}$ の天然ガスを消費している。同社はまた姉林会社日本 尿素工業株式会社を設立し1日 $100,000 \mathrm{~m}^{3}$ の天然が スより日産 $150 \mathrm{t}$ の尿素を製造する工場の建設に着手 した。その操業開始は昭和 32 年春と予想されている。 天然ガスを使用するプロセスに抢いても特に目立つ た進歩はみられないが合成原料ガスの製造法がリフォ 一マーによる吸熱的方法も酸素を便用する発熱的方法 も酸素を使用する発熱的方法も共に加圧下で行われる 傾向がある。ニッケル系触媒を便用しメタン水蒸気反 忘を外熱反応管内で行わせるリフォーマーは比較的低 温の一段リフォーマーの後に空気を吹込み単に触媒を 充填し加熱を行わない二段りフォーマーを使用しアム モニア合成原料ガスを製造する型式のものが多い。こ れによれば反危管が比較的低温で使用されるため加圧 が容易であつて 8 気圧前後で行われる。また酸素を使 用する不完全燃焼による場合は 30 気圧前後で行われ る。これらの加王法によれば圧縮用輜力の節約, 爾後 のガス精製装置の小型化，顕熱の回収利用の容易など の利益が得られる。

メタンを酸素によつて不完全に燃焼し，この焰の先 端を急冷してアセチレンを製造する Sachsse 法の概 要が第4 回世界石油会議に発表された8)。

メタンとアンモニアを白金触媒上て空気を以て不完 全に燃焼させ青酸を合成する Andrussow 法はわが国
においてアクリロニトリル系合成繊維への関心が潹ま るに及んでこれを工業化さんとする機運が起つてい る。

天然ガスの一種である㟶鉣がスを抜き出すことは， 災害予防に重要であるが北海道においてこのガスより カーボンブラックの製造が開始されたと報ぜられるタ。

\section{交献}

1) Ohem. Eng. News, Jan. 17, 212 (1955).

2) Ohem. Week, Feb 12, 77 (1955).

3) Ohem, Eng., Sep, 266 (1955).

4) Enrico Mattei, The Utilization of Natural Gas in Italy，第 4 回世界石油会議報告。

5) Tito Borelli, Acetilene e Acetaldeide da Metano，第 4 回世界石油会議報告。

6) Ohem. Zeit., Mar 5, 156 (1955).

7) Chem. Zeit., Nr. 6, Mar, 192 (1955).

8) E. Bartholome,, Acetylene by Partial Oxidation of Methane, 第 4 回世界石油会議報告。

9）日本天然瓦斯㙝会会報，94，昭 30.7。

\section{石淌鉱業の趨勢}

石油鉱業において最も経費を要するものは油田の発 見の費用である。それでアメリカ合䍃国の上うに石油 の豊富な国を除いては，各国とも国家が相当な金老出 して油田の発見に努力している。この点，わが国にお いては国家として石油の調査に対して余り熱心ではな かつたといえるのであつて，それが現在の国内原油の 生産不振の原因になつたとも考元られる。しかし最近 になつて漸くこの点に注意されるようになり，昭和30 年には政府により非常に積極的な方法がとられるに至 つた。これは石油資源開発株式会社の設立である。從 来は主として帝国石泊株式会社などに助成金として試 掘費の補助を行つてきたが，今後は政府はこの会社の 株の半分以上を出資し積極的な活動を行うことになつ た。この会社はこのような強力な援助により油田の発 見に対して裏門に活躍するので，将来の成果が十分期 待される。会社の設立が 12 月であつたため, 30 年に は具体的な仕事はできなかつたが，今後は試掘井の増 加，物理探鉱装置の強化，海底油田に対する調查など 虎差当つて行う予定である。

以上の上うな次第で, 従来㢦掘も行つていた帝国石 油株式会社は，今後は採油のみ行うことになつた。石 油の生産の最も多いのは，同会社の八橋鉱場であつて 現在では深さ $1,600 \mathrm{~m}$ 程度の油層が主力である。これ 以上の深い層の開発も今後は行わなければならないの 
で, 30 年 5 月より八橋鉣場の北部地金に深さ $3,000 \mathrm{~m}$ の井戸が掘られた。この機械は通産省の工業化試鍳の 助成金を得たもので，わが国で初めて作られたもので ある。装置は1)やぐらは高さ $40,5 \mathrm{~m}, 300 \mathrm{P}$ ジーゼル エンジン 3 台を使用し， $83 / 4$ in のドロウォークスと $7 \mathrm{x} / 2 \mathrm{in} \times 15 \mathrm{in}$ (压力 $200 \mathrm{~kg} / \mathrm{cm}^{2}$ ) のポンプを動かすをの である。わが国においてい $3,000 \mathrm{~m}$ 程度の井戸虔掘つ た経験はあるが，今回のように数カ月て完成すること は初めてのことである。予想以上の地質の硬さなどの ため, 予定より遅れて 30 年の内には予定の梁さには 達しなかつた。(目下掘り続けている。)今までには新 しい油層は発見されなかつたが, 地下の状態に関して は貴重な記録を手に大れることができた。その他の井 戸に関しては，八橋鉣場の雄物川地区の南部に新しく 深い層が発見されたことである。雄物川地区は浅い層 は以前より開発されておつたが, 樑い層 $(1,600 \mathrm{~m}$ 程 度）は発見されず，ほとんどあきらめていたものであ つた。しかし 6 月に掘つた井戸はこの深層を発見し， その結果八橋鉱場の南部地区が改めて重要視されるに 至つた。石油としてはとの他に発見された油田はない。 天然ガスとしては, 前年度に新潟県の明治村 (直汇津 の近くににガス田が発見され，30年になつて本格的に ガスを生産するに至つた。背斜構造にあるがスが発見 されたことは，わが国では珍しいことであつて，今後 もこの種類の天然がスが期待できる。

石油の 2 次回収は前年に引続いて行われている。水 攻法が効果を表すには，水を注入し始めてから 1 年位 を要するので，前年に行い始めたものが本年になつて 油の増産となる。油が増加する状態が 3〜5 年続き, その後は次第に減少する。この方法はすでにある油田 に対して行うものであるから，確実な増産方法であ る。最初から行つている八橋油田の雄物川地区は引続 いて油が増加しており，本年になつて油が増加し始め たものは新津油田の小口地区である。本年になつて新 しく実施したのは東山油田比礼地区と西山油田の長嶺 地区である。このように水攻泆はわが国で全面的に行 われる傾向にあり，研究においてもみるべきものがで てきだ?。

\section{交献}

1) 山本信夫, 石油技術協会誌, 20 然, 4 号(1955).

2) 藤弗清光, 同上, 20 先, 1 号(1955).

\section{石油精製業の趨勢}

昭和 30 年度に抢ける石油製品の需要は約 1,000 万 $\mathrm{k} 1$ と考元られ，前年度に比して 10\%以上の增加示 しているが，重油については引続き消費抑制の方釬を 堅持し「重油ボイラー設置制限法」を制定してボイラ 一用重油の消費量の堌加を抑え, 逆に石炭への再転換 虐奨励することとなつた。また原油抢よで重油に輸大 関税在復活し好調の石油産業から利益の一部を吸驱方 る方策虎実施した。

一方揮発油，灯油などについては十分な供給を榷保 することとしたので後半においては揮発油は稍々供給 過剩の状況となり次第に価格は軟化してきたのであ る。

かかる供給について従来から採られていた原油精製 主義は次第に強化され，ほとんぞ大部分の製品は国内 で生産されることとなつたので，精製工場を有しない 輸入業者は余力のある精製業者に原油学依託して精製 した。29 年度の原油および撚料油の外貨資金の割当実 樍と 30 年度のそれを比較すると次のように原油にお いては 20,000 千弗の増加を示しているにかかわらず， 揮発油に抢いては 3,000 千弗，重油においては 8,000 千弗の減少を示している。

\section{第 13 表}

原 油揮発油灯軽油 重油合計 千弗千弗 千弗千弗 千弗 $\begin{array}{llllll}\text { 昭和29年度 } & 98,364 & 10,156 & 684 & 27,573 & 136,777\end{array}$ 昭和30年度 $122,507 \quad 6,920 \quad 1,386 \quad 19,766 \quad 150,579$

また年初において下降の傾问にあうたタンカー運兵 は一時「U.S. M.C.」レート*の「-55\%」まで低下 したのであるが，年末から急激に上昇して高い時は $\lceil+30 \sim 40 \% 」 に$ 達し精製業の前途に一大暗影を投し たが，31 年にはいつて漸時落着き現在はフラットに 近いものとなつた。

これらの状況を背景として 30 年度の石油精製業は 前年に比しさらに内容的に躍進し，蒸溜能力に抢いて は約 25 万 bbl/日 (年間換算 14,500 千 kl) に達したのて ある。これら新しく増加した原油蒸溜装置はいずれも $10,000 \mathrm{bbl} /$ 日乃至 $20,000 \mathrm{bbl} /$ 日 の能力を有方る比較的 大型のもので遠隔自動制禦方式によつて完全に近いオ ートメーション化が行われている。また最近蒸溜に際 し原油を前処理することによつて蒸溜効率を高めるこ とが行われ始め，そのために原油脱塩装置が計画され てきたがその最初のものが日本鉱業船川工場の新設蒸 溜装置に設置された。これには化学的方式と電気的方 
式とがあるがいずれが能率的であるかは今後実施され る各工場の結果をみなければわからない。従来からわ が国の精製工場は規模が小さいので国際的競争にはき わめて不利であるといわれてきたが，30年度において 2 万bbl/日の处理能力もしくはそれを越えるものが 6 工場に達し，中には東亚燃料和歌山工場のごとく 4 万 bbl 級のものもできた。その他 30 年中に計画され 31 年度に完成するものを加えると，近く $3 \sim 4$ 万bbl の 工場は 6 工場となり太平洋岸にある主力製油所の過半 数は比較的に大規模となるのである。

次に精製工業の合理化の一環として最も大きな投資 々高度の掕術を要した高オクタン価自動車揮発油生産 装置は 29 年度において接触改質関係を一応整備した が，接触分解装置は 30 年度になつて運転を開始し た。

\section{日本石泊精製横浜工場}

型式 S. O. D. IV 型 流動接触分解装置

$\begin{array}{ll}\text { 能力 } & 5,600 \mathrm{bbl} / \text { 日 } \\ \text { 運転開始 } & \text { 昭和 } 29 \text { 年 } 11 \text { 月 } \\ \text { 分 解材 } & \text { ミンス含擸重質油(南スマトラ原油). }\end{array}$

\section{丸善石泊下津工場}

型式 U. O. P. 式流動接触分解装置

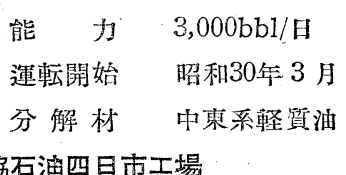

\section{大協石㴼四日市工場}

型式 フードリーフロー式接触分解装置

能力 $3,500 \mathrm{bbl} /$ 日

運転開始 昭和 30 年 5 月

分解枋中東系軽質油

以上 3 つの装置は運転開始後いずれも大した事故も なく比較的順調に稼動していて, 分解揮発油の収率は 日石精においては $55 \%$ に達し，他の 2 工場は $45 \%$ 前 後,オクタン価はいずれも 75 前後である。

接触分解装置の運転開始に伴つて分解がスの生産は 対原料油約 $20 \%$ に上り，これが処理は精製業合理化 と工場保安の 2 点から焦眉の急務となつた。これらの ガスは現在との大部分が液化がスとして然料に供され ているが 30 年度においてはその販売量は 20,000 tを 越元るものと考えられる。

この液化がスの需要增加につれて, 従来自家然料な ぞに消費していた熱分解がス，接触改質ガスなどの中 のプロパンーブタン溜分の回収が行われ，各精製工場 はほとんど液化ガスの生産を開始しだ。しかし目下計 画中の石油化学抢よびアルキレーション工業が寒施に
移れば当然此の内のプロピレン,ブチレンなどの不慨 和分がその原料として大部分使用されることとなるの である。

現在 (31 年 1 月) 稼動中の各工場の中で比較的大量 にガスを生産しているものおよび近い将来ての地域に 抢いてさらに大量のガス発生が考元られるものについ て試算すれば第14表のごとくである。(単位 $\mathrm{t} /$ 月)

\section{第 14 表}

$\mathrm{C}_{2}$ 以下 $\mathrm{C}_{3}$ 溜分 $\mathrm{C}_{4}$ 溜分 合計 供給 源

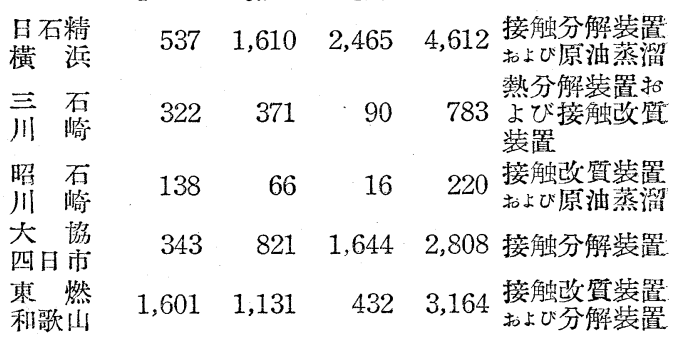

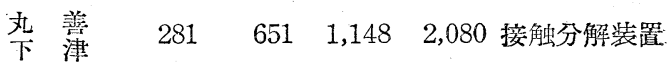

興 琶 $223 \quad 381 \quad 61.665$ 接触改澌装置

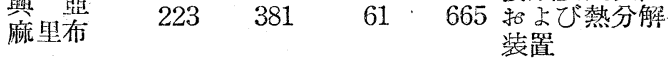

$\begin{array}{lllll}\text { 旦石精 } & 93 & 108 & 4 & 205 \\ \text { 接触改質装置 }\end{array}$

$\begin{array}{lllll}\text { 合 訫 } & 3,538 & 5,139 & 5,860 & 14,537\end{array}$

さて 30 年度の石油精製業で今一つ忘れられない問 題は旧軍然料旉の処分が決定したことである。

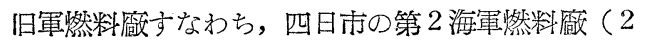
燃と略す) 徳山の旧第 3 海軍然料做( 3 燃)おょび岩国 の旧岩国陸軍燃廠の処分は戦後色々の問題を投じた䀣 案事項であつて, 特に 2 燃についてはその規模が雄大 なので政治的問題とまで発展していた。

しかし政府は 30 年 8 月 26 日の閣議におちて 2 然 は昭和石油へ，3燃は出光興産へ，岩国は日本鉣業打 よび三井石油化学へ夫々払下げまたは貸付けることに 決定して此の問題に一芯終止府を打つたの。である

この内で岩国は石油精製に直接関係のない方面一払 下げられたが，2然および 3 然はいずれも新しい精製 工場を建設するのを前提としており，前者は約 30,000 $\mathrm{bbl} /$ 日後者は約 $20,000 \mathrm{bbl} /$ 日 の処理能力を有する近代 的工場が計画されている。これらの決定の方針として は

（1）石油精製工場の規模を大きくする。

（2）製品輸入から原油精製に切換える。 の 2 つが大き打出されたのである。

以上 30 年度の石油精製業の概要を述べたが，その 具体的結果は今後に現れるが 30 年度において計画さ 
られた事項として, 各工場の常圧蒸溜装置の新設, 高 オクタン価自揮生産設備の拡大などがある。

蒸溜能力については，今後新式の大型装置が各工場 で計画されているが，こ机らはおおむ敉老朽装置の代 替えとして計画されているので, 経済 6 力年計画など と勘案して，世上に暄伝される様に過剩施設とはなら ない。

高オクタン価自揮生産施設の拡大の必要性は, 自動 車揮発油の需要量が急激に増大したことと, 自動車側 のオクタン価に対する要望が 75〜85 オクタンと大巾 に上昇して数年前に予想した 70 前後觉遥放上上廻つ たので, 改質油なり, 分解油の生産費が不足したこと であつて，このため現在でも四ェチル鉊の消費量が低 下しないのである。この対策として一般的には接触改 質法が採用され現在計画中のものはいずれもプラット フォーミング装置を建設する予定である。また改質装 置の増設に伴つて水素ガスの供給が安洒にできるので 水添脱硫法が簡単に実施されることになり，二，三の 工場て灯軽沺の水添脱硫が具体化してきた。

さらに接触分解の廃がスの利用についてアルキレー ションが訐画され，東燃和歌山工場に打いて軽質アル キレート $1,100 \mathrm{bbl} /$ 月 の生産能力茄有する装置が準備 されている。これが完成すれば極く少量の特殊潤滑油 苍除き石油製品の全部が中東原油乃至これに類する比 較的劣質原油から生産可能となる。

要するに二の数年来石酒精製業は合理化態勢を固め て来たのであるが，予想されるタンカーレートの上 昇, 揮発油市場の軟化, その他いろいろの業界に対し て負担を堌大するごとき事態に対処した場合に企業合 理化による生應原価の切下げが最も有力な対策である ことが 31 年度以降一段と鮮明に証明されることとな るであろう。

\section{文献}

1) 石油精製と石油化学

2）樋産省鈆業統計月報

* U. S. M. C. Rate: United States Maritime Commission Rate. (米国海事委員会)

油槽船の運貨基潐として世界的に犊用されている運 貸の公定率

\section{ペトロケミカルズの進展}

石油化学工業の母胎となる石油精製工業は 1955 年 初頭, 終戦時の 10 倍, 18 万bbl/日の処理能力を有文 るに至り，引続き設備の増強改善が行われた。天然が
スも前年 1.4 億 $\mathrm{m}^{3}$ の生産をみたが，新潟地区阿賀川 流域の新ガス田開発により，天燃がス化学工業がさら に発展することが可能となつた。石油の開発も 12 月 石酒資源開発株式会社の発足它み, 国内資源の堌産も 期待される。このような石油業界の活況を背景にわが 国の石油化学工業は引続き活潑に進展し, 本格的石油 化学工業確立の基礎ができ上つた。

通産省軽工業局では 2 月前年より引継いだ石油化学 技術想談会の結論を今後の行政に活用すると発表し， 4 月には昭和 30〜34 年度ヘトロケミカルズ需給推定 を行い，6月にはこれら竧綜合して石油化学育成対策 を明かにし，「石油化学工業の概要」苍発刊した。同 月同省内の日本産業構造研究会さ「石泊化学の現状と 問題点」について報告し，わ汃国の新座業として大い に進展すべきものと結論している。また鉣山局石油課 の主催する石油化学研究会も10月には「トトロケミ カルス 1 , 石泊精製と石油化学」発発刊した。通産省 は育成方釬の決定に基き，8月にはまず日本石油，丸 善石油, 三菱石油に開銀融資あつせん竞行うこと学明 かにし,ささらに各社の申請計画意具体的に検討し, 技 術導入や機器の輸入に努力した。

日本石油は 8 月日本石油化学裳設立し, イソプロピ ルアルコールおよびアセトンを Distillers Co.の技 術, Stone \& Webster Co. の設計にて行うこととし た。丸善石油は第二ブタノールおよびメチルエチルケ トンを Chemical Product Association の設計にて行 う承認を得た。三菱石油は 2 月修正計画を提出し，12 月には $3,000 \mathrm{bbl} /$ 日のプラットフォーマー, 750bb1/日 のニーデックス抽出装置購入を定めた。2 月三井化学 はチーグラー法ポリエチレンの導大安申請し, 翌月二 れが許可を得た。4 月には三井化学, 三池合成, 三井 銀行, 三井金属, 東洋高圧, 東洋レーヨン, 三井鉣山, 興亚石油が三井石油化学発起人会党結成し, 7 月三井 石油化学を正式に設立した。ポリエチレンのほかクメ ン法による石炭酸抢よびアセトンを基幹とし, エチレ ン, プロピレン, 芳香族化合物,アンモニアなどを製造 する綜合計画であるが，本年度内は計画の策定に止つ た。これに対抗する住友化学の ICI 高圧法によるポ リエチレン計画は 2 月 ICI 技術調查団と話し合い， 5 月には計画畫を呈出し，11月にはローヤリテーの支 払にまで進捗した。8月四日市燃料窔の明和石油一三 菱シェルグループへの正式払下げが決定し，昭和石油 は9 月四日市旧海軍燃料阙活用語十画を確立し，10月に は三菱シェルも合成ゴム製造計画, 11月にはスチレン モノマー，硫安などを第 1 期工事とする綜合計画を発 
表した。

帝国石油も新潟市にてカーボンブラックの製造に着 手し, 日本瓦斯化学工業は住友化学協力の下 Chemial Construction Corp. の技術により天然ガスからのア ンモニア，尿素製造工場の建設を進めている。重油分 解によるファウザー法アンモニア合成計画も 1 月三菱 化成, 宇部興産, 山陽化学の 3 社に許可された。ポり

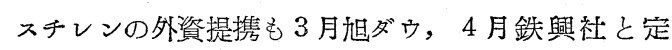
つた。そのほか, 古河系諸会社の綜合計画, 東京ガス のエチレン, 三菱シェル, 山陽化学, 日本ゼオンの合 成ゴムの計画が話題になつた。

然料協会は 1 月には石油化学工業, 6 月には石油化 学原料に関する特別講演会を開いた。各社の石油化学 婳画を聞く講演会を8月には日刊経済新聞社，10月 および 12 月には日本化学工業協会が開催し, 石油化 学に関する各種の小講演会, 座談会が活潑に行われ た。

発表論交も多数にのほつたが，通産省関保官の箨に なるものが多く, 吉田半右工門1), 入江明2), 藤井辰 雄 ${ }^{3)}$, 磯西敏雄 ${ }^{4}$, 馬替泰 ${ }^{5}$, 上原益夫 ${ }^{6}$ 代 らが啓蒙的 論交をとれぞれ発表している。学校関係では神原周 氏7) 抢よび堤繁氏8 が見解を明かにし，後者は堤プロ セスを提称した。民間側では玉置明善9)，渡辺伊三郎 10), 川瀬義和11), 山田省二12)氏らのほか137, 各業界の 諸氏がそれぞれの業界と石油化学工業の関連について 論じている。その他各社の竐画をのせた雑誌も数多く 見られ特集を行つたものもある。変つた所では I. Oganesoff 氏はPetr. Refiner に「日本の石油化学計 画」と題してわが国の石油化学製品の需要, 各社の計 画などをまと为てのせている14)。

昭和 30 年度工業技術院試験研究補助金交付を受け たもののうち,石油化学関係は日本石油「アセトン誘導 体の製造」,倉敷レーヨン「石油からアセチレンの製造」 などの工業化研究抢よび日本瓦斯化学工業「芳香族岸
化水素の抽出」，善石油「石油ガスからイソブチレ ン,ブタン,ブチレンの分離ならびに誘導体の製造」の 応用研究が挙げられる。文部省化学研究促進補助金対 象中には京都大学工学部「石油オレフィンの総合利用 によるポリェチレンその他の合成高分子製造研究」, 大 阪大学工学部「石油化学に関する研究」などがあり, 石油化学の研究も各方面に亘り着々進行しつつある。

国外に目を転ずれば本年度全世界の化学工業は活況 裡に終始し，新興の石油化学工業は特にその躍進が著 しい。米国に抢いては漸く石油化学工業の設䚛能力が 製品需要を上廻る状態に達した。Bateman 氏の発表 によると第15表15)のごとく，生産額は 1,409 万七て前 年の $17 \%$ 增しである。

前年までの総投資額は 30〜40 億デルであつて, 本 年中に 4〜5 億ドルの投資が追加され, 米国抢よびカ ナダを通じ, 187 会社, 327 工場が操業または実施計 画中で, 前年に比し24会社の増加である。内石油会社 系 63, 石油化学会社 45, 化学会社 72, 残りが合弁 会社系16)である。挍術的には Phillips Chemical Co. の中圧法ポりエチレン Marlex の工業化, Goodrich Chemical Co. や Firestone Co. のイソプレン䒺合 成ゴム(Ameripol17) など)，リフォーマーガスからの

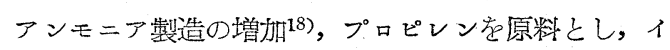
ソプロピルアルコールおよび過酸化水素より，アクロ レイン，グリセリンおよびアセトンを製造する Shell Chemical Co. 法 ${ }^{19}$, U. S. Industrial Chemicals Co. のイソセバシン酸の製造20)などに著しい進歩が認めら れる。

英国19でも石油工業の発展に伴い，利用できる資源 が堌加し，石油化学への大投資が継続している。特に ナイロン, テリレン, ポリエチレン, 塩化ビニイル, アルコールの増産が著しい。エポキシ樹脂, アルキル ベンの工場も建設中で合成ゴムの大計画も着実に進行 している。

\section{第15表 米国ペトロケミカルズ生産量とその金額}

品

品名

年度礼よび前年比

ペケ(脂肪族

占方

ズ $\left\{\begin{array}{l}\text { 無機化合物 } \\ \text { 合 }\end{array}\right.$

全化学製品

ペトロケ（化学製

ミカルズ 品比
生産 量 (万 $\mathrm{t}$ )

\begin{tabular}{|c|c|}
\hline $953 \quad 1954$ & 前年比 \\
\hline
\end{tabular}

年 年 $(\%)$ 年

$\begin{array}{llll}736 & 719 & -2.4 & 864\end{array}$

$\begin{array}{llll}100 & 135 & +36.3 & 145\end{array}$

$314 \quad 349+11.6 \quad 400$

$1150 \quad 1184$

$+4.7 \quad 1409$

$52105220+2.65770$

$22 \%$

$23 \%+4.5 \% 24.4 \%$
前年比

$+20.3$

$+6.6$

$+14.3$

$+17.0$

$+10.8$

$+6.1 \%$
生産金額（億ドル）

\begin{tabular}{rccrc}
\hline $\begin{array}{c}1953 \\
\text { 年 }\end{array}$ & $\begin{array}{c}1954 \\
\text { 年 }\end{array}$ & $\begin{array}{c}\text { 前年比 } \\
(\%)\end{array}$ & $\begin{array}{c}1955 \\
\text { 年 }\end{array}$ & $\begin{array}{c}\text { 前年比 } \\
27.4\end{array}$ \\
23.3 & -14.9 & 27.6 & +18.3 \\
2.8 & 5.2 & +85.5 & 5.4 & +3.8 \\
2.0 & 3.2 & +60.0 & 3.5 & +9.4 \\
32.2 & 31.7 & -1.5 & 36.5 & +15.2 \\
61.0 & 60.4 & -1.0 & 67.5 & +11.7 \\
$52.7 \%$ & $52.5 \%$ & $-0.4 \%$ & $54.0 \%+2.9 \%$
\end{tabular}


フランス:2)のアセトン,フェフールは前年の $35 \%$

増, 合成洗成は $25 \%$ 堌, プラスチックスは 5 年間に倍 加している。接触分解などの増加により地中海沿岸で は国際価格のペトロケミカルズを製造できるようにな り，南フランス Lacq に発見された天然がスからアセ チレンなどの製造が計画されている。

西ドイッの天然ガスも 1.5 億 $\mathrm{m}^{3}$ に達し，これに基 き Farbenwerke Höst A. G. ではテリレンの製造 に着手している。Rhein Olefin Werke G. m.b.H. についで Kohle-Ölā Chemie G. m.b.H. おょび Farbenwerke Höst もポリエチンンの製造に乗出 した。Bunawerke Hüls およひ Buna Co. (Bayer, Höchst, BASF 合弁会社) の合成ゴム計画も国際規 模で進行している。

オランダの Shell Chem Co.では 1956 年完成を 目標にエピクロロとドリン，エチンングリコール製造 の計画を進め, Pernis の Shell 製油所は農薬アルド リン、ジェルドリンの製造を始めた。Nederlandsche Dow Matschappy 社はプラスチックスなどの石 油化学に乗出した。ベルギーの Societe Chimique des Derives du Petrole (11 会社合弁) ではエチレ ンオキシド，エチレングリコールのプラントを 1956 年完成の予定である。スペイン23)でも Compania Espanola de Petroleos が芳香族㟶化水素の回収, アンモニアの製造を訐画し，ハンガリー24)もルーマニ アの石油ガスから肥料製造を計画中である。ソ連25)の 有機薬品製造量は戦前の 5 倍に達し, ‘゙ルガ河流域で は芳香族炭化水素がつくられ，合成ゴムの原料もアル ニールから石油に変りつつある。イタリーのアンモニ アは前年に比し 13\% 増，プラスチックスは 30〜35 \%増, ナイロンは 25\% 堌で Azenta Nacionale Idrogenazione Co. (ANIC) は合成ゴムとアンモニア 盵料の製造に着手した。

南米ブラジルの Cia Braziliera de Estireno $\mathrm{Cu}$ tatao ではスチレンモノマーや，アンモニアの製造計 画定進め, ペルーの2 社でアンモニアの合成が1956年 より実施される予定である。べネズェラも Monticatini 社と提携し，アンモニアを手始めとする石油化学 に着手した。

オーストラリヤの Australia Petroleum and Chemical Corp. は年末末でに700万ドルの石油化学工場 在完成する。サウジアラビア政府も 40 万 $\mathrm{t}$ の硫安と $500 \mathrm{t}$ のドライアイス存, トルコはアンモニアを, 台湾 は 260t/日のアンモニアをそれぞれ製造する計画が進 んでいる。
1955 年中わが国でも外国でもぺトロケミカルズは 活潑に進展し，ますますその将来は明るい。

\section{交献}

1) 吉田半右衛門, 然協誌, 34, 274, 昭 30 .

2) 入江明, 化学と工業, 8, 106, 昭 $30 ; 8,1057$, 昭 30 .

3) 藤井辰雄, 工業技術, 6, 7, 昭 30 (6).

4) 磯西敏夫, 石油, 11, 14, 昭 30 (5).

5) 馬替泰, 有機合成協誌, 13,184 , 昭 30 ; 工業技 術 5, 2, 昭 30 (7).

6) 上原益夫, 石油, 11, 8, 昭 30 (4).

7) 神原周, 石油, 11, 10, 昭 30 (5), 有機合成協誌 13, 245, 昭 30.28 , 日本ゴム協誌 685 昭 30.

8) 堤繁, 有機合成協誌, 13,566 , 昭 30 ; 化学の領 域, 9, 26, 昭 30; 化学工業 6, 1073, 昭 30; 燃協誌, 34, 356, 昭 30 .

9) 王置明善, 石油, 11, 21, 昭 30 (11); 同誌, 11, 18 ; 昭 30 (5).

10) 洨㲽伊三郎, 石油, 11, 20, 昭 30 (7); 化学工 学, 19, 615 昭 30 (12).

11) 川瀨義和, 石油, 11, 16, 昭 30 (10); 油脂 8, 51 , 昭 $30(7)$.

12) 山田省二, 石油, 11, 20, 昭 30 (9); 燃協誌, 34, 518 , 昭 30 ; 日石技報, 7, 629, 昭 30 .

13) 土屋敦彥, 有機合成協誌, 13,555 , 昭 30 ; 野口 靜夫, 同誌, 13, 395, 昭 30 ; 渡辺謙造; 石油, 11 , 16 , 昭 30 (12); 橋本元雄, 石油と油脂, 8, 70, 昭 30 (1); 竹内俊一, 同誌, 8, 26, 昭 $30(2)$; 波 多野郊三, 同誌, 8, 39, 昭 $30(9)$; 土屋弘太郎, 同誌, 8, 4, 昭 30 (8); 中島事, ラバーダイジェス $卜 ， 7,2$, 昭 $30(10)$; 日石社長室第三課, 石油之油 脂, 8, 12, 昭 $30(10)$.

14) I. Oganesoff, Refiner, 34, No. 10, 163 (1955).

15) V. B. Guthrie, Pet. Processing, 10, 1387 (195 5).

16) Pet. Proessing, 10, 1413 (1955).

17) Ohem. Eng. News, 33, 5026 (1955); J. J. Mc Ketta, Pet. Refiner, 34, [12], 116 (1955).

18) R. L. James, Pet. Refiner, 34, [6], 17 (1955).

19) Pet. Refiner, 34, [12], 160 (1955).

20) Industrial Chemist, 61, 618 (1955).

21) Pet. Refiner, 34, [10], 198 (1955), Chem. Eng. News, 34, 40 (1956).

22) Ohem. Eng. News, 33, 3258 (1955).

23) C. B. Whyte, World. Pet., 26, [12], 86 (1955).

24) 化学工業日報, 昭 30.10.26.

25）化学工業日報, 昭 30.9.26

\section{石油に関する研究}

石油精製工業が石油化学工業の進展に伴つてますま す活況苍呈するとともに，その影響下に基碟，応用両 面に亘つて石油に関する研究もますます盛大となりつ 


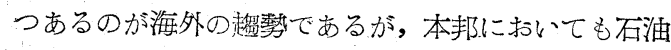
製品の量的競争の段階堂漸く脱し，今队その質的競争 が展閉されようとする機運の下に, 石油関係の研究も 基礎部門においては一段之着実，基礎的に深く掘り下 げられまた応用部門においては時勢の進運に応じて 愈々嶄新さを加えつつあるように見受けられる。以下, 各部門にわたつて 30 年度における内外の研究を集録 してみよう。

まず分析法の関係では， 1955 年半ばにガスクロマ トグラフ法1),8)を応用した Chromacon がポトビルニ アック社から発呈され，本法によるガス分析法が普及 してきた。またポドビルニアック式低温分溜装置には

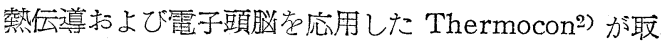
附けられて性能は一段と向上した。同様の原理を応用

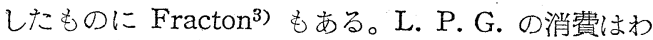
が国でも近年とみに普及しつつあるが，英国における L.P. G. および類似炭化水素がスの現行試験法につ いての展望4が発表されまた A. E. Heron 氏5)は眽 酸に㞸化水素がス吸収させることにより炭化水素が ス中の 1〜100ppm の僆量窒素の定量を行つた。質量 分析計による分析は従来は炭化水素がスに応用されて いたが R.J. Clere 氏6) らはクロマトグラフ法で分離 した飽和溜分中のアルカン, 単環シクロアルカン, 綃合 環シクロアルカン, 単環芳香族, ナフタレン誘導体の 質量分析計による分析を行つた。クロマトグラフ法は 石油分析にはすでに常套手段となつているが，B．W. Bradford氏ら》は炭化水素混合物のクロマトグラフ分 析について綜説した。これらの方法を利用した原油ま たは溜出油の成分分析報告も次々と発表されつつある が，丸善石油の林氏 ${ }^{9}$,10)らはアラビアその他のガソリ ンの成分，一般性状および硫黄分布について述へてい る。淊中の微量成分，特に金属の分析定量には分光分 析法の応用が普灭しこれに関してはJ. Noar 氏11 お よび上妻氏12)の總説があり，H. V. Drushel 氏13) は Hasting の方法に基いて高分子硫化物を分光光度計を 用いて定量し E. B. Childs氏 ${ }^{14}$ ( 石油灰分の分光分析 值の解析に当り，対数函数の応用について報告してい る。四エチル鉛定量には F. W. Lamb E15)のX線焱光 法があるが，この方法の誤差は $0.0026 \mathrm{ml}$ で, AST M“法との差 $0.0028 \mathrm{ml}$ である。W. Hubis 氏16)はポー ラログラフによる迅速定量法を発表した。硫黄分定量 についても遊離硫黄のポーラログラフ法17), 微量ラン プ法18)などがある。

次に試験法の関係では，H. E. Oehler氏19)は減圧下 のエングラー蒸溜と真沸点蒸溜の関係について，また
J. C. Chu氏20)は土ングラー蒸溜と平衡蒸発との間の 相関係について報した。昭石の藤田氏91は $50 \mathrm{cc}$ 程度 の小量試料の分溜を目的とする同心円型精溜塔の性能 について報告し，日石の福島氏22.)らは腐蝕試験の簡易 化，定量化を目的として，試験片に光を当て反射光量 の測定をする方法を考案した。また N. F. Nickol 氏23) は CFR セタン価測定エンジンの燃焼室容積測定の改 良法を洘案した。C. D. Gal'pern 氏出) はり連におけ る石油製品比重の温度に対する補正に関する研究の歴 史を述べてる。

物理的扎よび化学的諸性質に関するものの中, 蒸気 圧に関するものでは，H. S. Meyers 氏(5),‘6)(ま高沸点 炭化水素の蒸気圧を測定し, また低沸点の炭化水素に ついて温度一沸点一蒸気圧の関係を示す表走作成した。

W. J. Tomsie 氏 ${ }^{2 i}$ ) は精溜結果より真蒸気圧を計算 した。，また光学的研究28)29)も三，三行われている。

G. C. Ackroyd 氏30!は中東残渣重油の流動性について 電気伝導度を測定し, R. T. Edward氏31)はパラフィン 蠟の成分と引張強度の関係について報告した。3 成分 の液々平衡では心゙ンゼンと数種のパラフィシ炭化水素 および液体 $\mathrm{SO}_{2}$ 系に関し ${ }^{32}$ また東大工の高橋敏郎氏

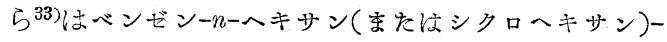
ヂメチルフォルムアミド氷溶液の 3 成分系に関し報告 している。高橋氏の研究では同系にさらに流動パラフ インを加えれば，97〜98\% の純度でベンゼンが抽出 され，トルエン，キシンンでは100\%の純度のものが

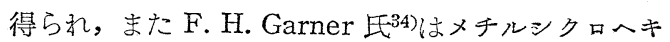
サントルエンフルフラールの 2 または 3 成分の気液平 衡について報告している。 J. W. Moore E35)はポル フィリン系化合物の分析およびそれを含も油，例えば 頁岩油つ表面または界面活性について研究し, 界面活 性と成膜性はポルフィリンおよびN化合物の含有量に 比例する事を認め，また V. G. Gutsalyuk 氏36)も同 様の研究をした。東大工の泉富雄氏37)らは原油, 石油 製品のエアーホームの破壇性能を研究し, 破泡力は合 まれる破泡性物質と粘度とによること老見した。

分離法関绿では，米国化学会第 126 大会に提出され た，(1)液相吸着，(2)有機液状混合物の蓺桩散による分 離，(3)廻転区び充填蓺拡散分離塔，(4)熱拡散製法によ る潤滑油，(5)尿素及びチォ尿素附加物，(6)芳香族抽出 の選択的溶剤, (7液体 $\mathrm{CO}_{2}$ による抽出, 8) 硫黄化合 物之芳香族炭化水素の液体 $\mathrm{SO}_{2}$ による抽出, (9)中東 原油中の硫黄化合物, 10キシンン異性体の分離, (11)蒸 溜による分離法の進歩の 11 論文からなる, 炭化水素 抢び関連化合物の分離に関する進歩が Ind. Eng. 
Chem. 誌に特集38)された。本邦では三菱石油の土屋

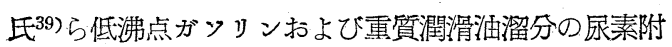
加物による直鎻パラフィンの分離をせタンまたは $\mathrm{C}_{10}$ 〜25 の正パラフィンを添加することにより効果的に行 い得る如く改良した。日本鈗業の赤井氏40)らはこれと 同し現象を逆の立場から利用してトランス油原料に不 安定な軽質パラフィンの附加物を添加して起る置換附 加について報告し, また液体 $\mathrm{NH}_{3}$ を尿素の溶剤とし て使用することにより附加物の粒度を大ならしめ, 濾 過が容易になることを認めた41)。資技試の黒川氏42?は 昨年に引続いてシリカゲルアロソーブ法について研究 した。脱着剤の芳香族と飽和炭化水素は同時に使う方 法と別々に使う方法とがあるが前者は操作が簡便であ り, 後者は純度回収率の点に打いて勝つている。他に E. R. Fenske 氏43)はUdex 法で抽出した芳香族混合 物の精溜について述へ J. L. Tiedje氏(44)は高級ヶトン 類の脱蠟溶刘としての性質について述へている。さら に Linde Air Product Co.により創案された合成ぜ オライトを吸着剤とし分子の大きさに従つて混合物質 老分離する分子穊なるものが報告されている45)。これ は崖化水素ガスの分離に応用できる。

次に崖化水素コンバーション関係の報告はその数も きわめて多い。接触分解用シリカ・アルミナ系触媒の 構造, 活性などの研究は一応出尽した感があるが, 早 大の山本氏 ${ }^{46)}$ らは触媒の表面構造と触媒作用吸着作用 に関し触媒の気孔と活性を動力学理論に基いて検討し た。J. D. Danforth 氏4i) は触媒の活性中心は Lewis 酸と Brönsted 酸の複合体として表されると報した。 K. V. Topchieva 氏48) はシリカ・アルミナ比の異る各 種触媒の同一吸着面積への炭化水素ガスの吸着を研究 しシリカ 70 : アルミナ 30 の触媒が最高の活性を有 し, 表面積, 平均孔径抢よび活性化ェネルギーとシリ カ・アルミナ比は関係はないとしている。D. E. Nicholson 氏49) 引活性度の違う一連の触媒で $i$-ブタンお よびnーブタンを分解し, 静的活性度と分解率の满足 军バき一致を得, E. A. Andreev 氏は放射性炭素原 子を含せメタン, プロパン, $i$-ブタンを使つて 2 次分 解反応について研究した。接触分解反応に対する芳香 族の抑制作用拉上びアリカリ土属金属イオンの触媒人 の毒性についてはそれどれS. N. Obryadchikov 氏(50) および J. D. Danforth氏(51)が報告している。プラン トによる接触分解に関しては金崎氏5?が，また接触分 解ガスについては山田氏53)が紹介した。

芳香族化に関しては，J. E. Conner氏 ${ }^{54)}$ は無活性 のシリカ・アルミナに担持させた白金触煤で研究し， $860^{\circ} \mathrm{F}$ ，水素 $1751 \mathrm{~b} / \mathrm{in}^{2}$ 加圧， L. H. S. V. 1.5 で 89 \% のナフテンがベンゾールに変ることを認めた。 $\mathrm{B}$. A. Dadashev氏 ${ }^{55}$ は V-Al触某の芳香族化活性につい て研究し、プラントに扱る反応の研究としてW. P. Hettinger ${ }^{56)}$ は Hydroforming 法, G. R. Danaldson 氏(57)は platforming 法, H. Heinemann ${ }^{58)}$ は Houdryforming 法における反応機構を論し，三菱石油の 土屋氏59引は石油からの芳香族生産について綜説した。

ガス状炭化水素の重合に関してはV.I. Isagulyants 氏600は $\mathrm{AlCl}_{3}-\mathrm{NaCl}$ 系触媒によりプロピレンを重合し て液状油を作り, J. J. Verstappen 氏61) の研究では シリカ・タングステン酸系触媒によりプロピレンを重 合すれば，䅺準條件では86\%が液状重合物になりそ の内の $28 \%$ 四重合体であつた。この触媒は燐酸触媒 よりも四重合体生成の性質が强い。J. P. Hogan 氏62) はシリカ・アルミナに担持させた酸化ニッケル触媒は $\mathrm{C}_{2}, \mathrm{C}_{3}$ のオレフィンを重合して自動車ガソリンを製造 するに好適であると報じた。その他，早大の山本氏633 らは水素合有量多くオレフィンの少い燃焼性のよい都 市ガスを石油の分解により製造することを目的として 酸化ニッケル触媒の䎇法; 硫化水素による被毒, 水性 ガス反応の促進能力などについて報告した。東大工の 安東氏ら ${ }^{64)}$ (よがス製造の目的でミナ゙ス原油の100〜320 ${ }^{\circ} \mathrm{C}$ の 4 溜分を 700 800 ${ }^{\circ} \mathrm{C}$ で高温熱分解した。土千 レン生産量は $800^{\circ} \mathrm{C}$ が最高, プロピレン・ブチレン は $750^{\circ} \mathrm{C}$ が最高であり, 液状油中の芳香族は温度の

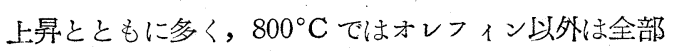
芳香族であつた。

石油製品中の硫黄分の悪影響を防ぐには, スイート ニング法, 脱硫法が行われるが, 脱硫法には湿式と乾 式とが考えられ, 乾式, 特に水素添加脱硫法はリフォ ーミングの発達により水素源が確保されたため次第に 注目されるようになつた。、イドロファイニング，オ ートファイニング, ニニファイニング, サイクロヴァ ージョンなどの各法はすでに相当数のプラントが稼動 しているが，これらに関しての交献は日石技報65に特 集として紹介されており，またT. S. Laszlo 氏(6)は接 触脱硫の溶剤抽出法に対する利点についてて解説してい る。W. C. van Zijlle Langhout 氏67) は中東原油がス 油溜分を $\mathrm{Co}-\mathrm{Mo}-\mathrm{Al}_{2} \mathrm{O}_{3}$ 触媒で $375^{\circ} \mathrm{C}$, 水素圧 $26 \sim$ 91atm で脱硫した。高圧程脱硫効果は高く, 分解はこ の程度の條件では生起しない。水素圧がさらに高く， $150 \mathrm{~atm}$ 程度になると芳香族の水添反忘が起る。W$\mathrm{Ni}$ 系触葉については M. D. Abbott氏65)が報告し，国 内では東大工の安東氏69y,70) らは Co-Mo 系触媒によ 
りアラビア末洗ガソリンおよび軽油の水添脱硫を行つ た。ガソリンでは 95〜100\% 脱硫し, 軽油では 74.5 \%が最高であつた。東工大の斯波氏ら71)も Co-Mo 系触媒, $\mathrm{NiO}-\mathrm{MoO}-\mathrm{Al}_{2} \mathrm{O}_{3}$ 系触媒で 5 60atm の水 素圧下で軽油の脱硫を行つた。神工試の仲井氏らて2)は シリカ・アルミナ触媒によるメルカプタン類の除去に ついて，その鳋媒作用および仕事函数を測定した。接 触法以外では, 東工大の神原氏らて3)は炭化水素成分に 変化を与えずに硫黄化合物のみを除去する方法につい てアラビアガソリンを酿酸・ $\mathrm{H}_{2} \mathrm{O}_{2}$ 水溶液混合物の有 穖過酸で処理しよい結果を収め, 各硫黄化合物の反応 について論じた。東工大の桜井氏らて4はニニン゙ール法 の作業條件について研究している。

内燃機関燃料に関するものでは，広島大の宫西氏 ${ }^{(5)}$ は四エチル鉊に代るアンチフック郕を求めることを目 的として，炭化水素の低温酸化を実験し， nーパラフィ ンの酸化生成物であるフォルムアルデセドは然煃室内 の六方晶形微結晶により生成が促進されることを認め 四ェチル鉊が然えてこの六方晶形結晶を被覆してアン チノック効果寺生ずると解䣋し, シリンダー内鉛被 覆したエンジンを運転してノック現象を減少さけた。 R. Vichiniesky 氏 ${ }^{76)}$ はイソオクタンーnヘプタンー心゙ ンゼンの混合燃料を用いてオクタン価と燃焼時間の相 関関䋆を求め, B. J. Reitzer氏iz)はシクロペンタンと イソォクタンの冷焰酸化およびデトネーションについ

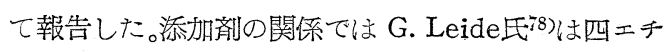
ル鉛添加限界量算出の実験式を提案し，また Tritoyl Phosphate について紹介し, W. M. Cumming氏79) は chromium hexacarbonyl のアンチノック性につ いて述へ, 日大工・书川氏ら 80 は分解がソリン用の抑制 版としての安価なアミノナフトール系化合物の性能を 研究し，1,2-アミフナフトールではかなりの効果がみ られた。R. S. Jessup 民81)は航空ガソリンのアニリン 比重積と発熱量の関係について述へ, R.W. Donahue 氏\$2)は誘導期間試験とがンリンの安定性について報告

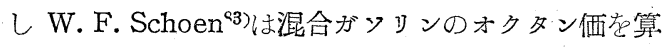
出するに当り 2 成分のオレフィン含有量の差により Blending appreciation factor 設定して,これによ り補正をする方法を提案している。ガンリンの赛用試 験は各方面で行われているが，国内では三菱石油 ${ }^{84)}$

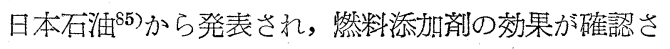
れてたＨ. Schildwächter 氏\$6)はガンリンのエンジン に対する機械的, 熱的, 化学的影響について報じてい， る。米国文献には都宁空気污染の見地から車両エンシ ンの廃ガスの分析に関する報告が散見される ${ }^{87}, 887,897$,
90)。分析方法には主に質量分析計を使用し，廃がス中 の未然炭化水素, $\mathrm{CO}, \mathrm{HCHO}, \mathrm{N}$ 酸化物等とエシジン の運転條件の関係を研究しているが, 未然がンリン量 は巡航く低速＜減速で，エンジンへの供給量の $23 \%$ が末燃分として排出されることもある。

自動車ガソリンの品質が向上する反面, 重油は益々 贫質のものが多くなりつつあり，添加㓮の使用はすて に一般化し，また匝分による腐蝕なども散見されるよ うになつてきた。資技試の重田氏91》は市販助然䬉の土 ンジン試験について講演し, 三菱石油の小幡氏ら ${ }^{92)}$ は, クェート文びリア重油中の灭分を 18〜8 堸にぬり, 加熱して腐蝕を研究し, 腐蝕はV $\mathrm{V}$ 化合物により起り, アルカリ金属扎よび $\mathrm{S}$ の存在で促進され, $\mathrm{MgO}, \mathrm{SiO}_{2}$ により抑制されることを認めた。重油の安定性, 流動 性などに関しては印藤氏93)が綜説を書いている。

アスファルト関䋆では, 日石の水谷氏94)はカットバ ックアスファルトの蒸溜性状と溶剤の蒸溜性状との関 係について報告し，東工大の五十嵐氏95)はストレート 及びブロンァスファルトに吹込アマニ油を混合して空 気酸化し, 高軟化点でかつ低温脆化の少いアスファル トコンパウンド製造法を研究した。 L. R. Kleinschmidt 氏96) はアスファルトをクロマトグラフ法でグル ープ別に分析した。

交

献

1) W. J. Podbliniak \& S. T. Preston, Petr. Refiner, 34. No. 11165 (1955).

2) W. J. Podbliniak, Petr. Eng., 27, No. 5 C17 (1955).

3) K. H. Clough, Petr. Eng., 27, No. 9. C-26 (19 55).

4) Petroleum Gas Panel of I. P., J. Inst. Petr., 41, 54 (1955).

5) A. E. Heron, J. Inst. Petr., 41, 63 (1955).

6) R. J. Clerc, A. Hood \& M. J. O'Neal, Anal. Ohem., 27, 868 (1955).

7) B. W. Bladford, D. Harvey \& D. E. Charkley, J. Inst. Petr., 41, 92 (1955).

8) H. W. Patton, J. S. Lewis \& W. I. Kaye, Aral. Chem., 27, 170 (1955).

9) 林喜世茂他, 丸善石油技報, No. 2,12 , 昭 30 ,

10）林喜出茂他，丸盖石油技報，No. 1, 23，昭 29.

11) J. Noar, Inst. Petr. Rev., 9, 187 (1955).

12）上妻常夫, 丸善石油, 技報, No 2 , 90, 昭 30 。

13) H. V. Dushel \& J. F. Miller, Anal. Ohem., 27. 495, (1955).

14) E.B. Childs \& J. A. Kanehann, Anal. Ohem., 27, 222 (1955).

15) F. W. Lamb, L. M. Niebylski \& E. W. 
Kiefer, Anal. Ohem., 27, 129 (1955).

16) W. Hubis \& R. O. Clark, Anal. Chem., 27, 1009 (1955).

17) S. Harrison \& D. Harvey, Analyst, 79, 640 (1955).

18) W. R. Battles, Pet. Eng., 27, No. 7, C-41 (1955).

19) H. A. Oehler \& M. Van Winkle, Petr. Eng., 27, No. 1, C-10 (1955).

20) J. C. Chu \& E. J. Staffel, J. Inst. Petr., 41, 92 (1955).

21）藤田青男, 日本化学会第 8 年会講演, 30 年 4 月 -1 日。

22）福島健重, 加藤久明, 日石技報, 7, 207 (昭 30)

23) N. F. Nickol, Pet $\%$. Eng., 24, No. 6, C-50 (1955).

24) G. D. Gal'pern, Trudy Inst. Nefti. Alad. Naik. S. S. S. R., 4, 101 (1954).

25) H. S. Meyers \& M. R. Fenske, Ind. Eng. Chem., 47, 1652 (1955).

26) H. S. Meyers, Ind. Eng. Ohem., 47, 1656 (1955).

27) W. J. Tomsie, Oalif. Oil World, 48, No. 1, 35 (1955).

28) I. S. Satter-Zand, Izvest. Akad. Naik. Azerbaizhan S. S. R., No. 9, 21 (1953).

Referat. Zhur. Khim., No. 38596 (1954).

29) F. H. Garner O. B. E., C. W. Nut. \& A. Labbauf, J. Inst. Petr., 41, 329 (1955).

30) G. C. Ackroyd \& A. G. Lowe, J. Inrt. Petr., 41, 229 (1955).

31) R. T. Edwards, Ind. Eng. Ohem., 47, 2555 (1955).

32) C. N. Satterfield, J. H. Powell Jr., E. A. Oster Jr., \& J. P. Noyes, Ind. Eng. Chem., 47, 1458 (1955).

33）高橋敏郎他，日本化学会第 8 年会講演 30 年 4 月 1 日。

34) F. H. Garner O. B. E. \& R. I. W. Hall, $J$. Inst. Petr., 41, 1 (1955).

35) J. W. Moore \& H. N. Dunning, Ind. Eng. Chem., 47, 1440 (1955).

36) V. G. Gutsalyuk \& M. M. Kusakov., Izvest. Akad. Nauk. Kazakh. S. S. R. Ser. Khim., No. 8, 122 (1955).

37) 島富雄他, 日本化学会第 8 年会講演， 30 年 4 月 2 日, 工化誈, 58, 846 (昭 30).

38) Ind. Eng. Chem., 47, 2, 192 (1955).

39）土屋敦彥，田上良吉，日本化学会第 8 年会請演， 昭 30 年 4 月 1 日。

40) 赤井吉士，矢田值樹，工化誌 $58 ， 747$ (昭 30).

41）赤井吉士，矢田直樹，工化誌，58，366（昭30).

42）黑川広三，然料協会「石油とコールタールに関す る特別請演会」, 30 年 11 月 2 日。
43) E. R. Fenske \& D. B. Broughton, Ind. Eng. Chem., 47, 714 (1955).

44) J. L. Tiedje \& D. M. Macheod, J. Inst. Petr. 41, 37 (1955).

45) E. B. Brien, Petr. Eng. 27, No. 3, C-35 (195 $5)$.

46) 山本研一, 森田義郎, 日本化学会第 8 年会丵演, 30 年 4 月 1 日

47) J. D. Danforth, J. Phys. Chem., 59, 564 (19 $55)$.

48) K. V. Topchieva G. M. Panchenkov \& M. V. Lomonosova, Uchenye Zapiski Moskov Gosidarst Univ., No. 16413 (1953).

49) D. E. Nicholson, Ind. Eng. Chem., 47, 1216 (1955).

50) S. N. Obryadchikov \& D. M. Soskind, Neftyanoe Khoz., 33, No. 6, 72 (1955).

51) J. D. Danforth, J. Phys. Chem., 58, 1030 (19 54).

52）金崎健児，燃協誌，34，539（昭 30）.

53) 山田省二, 燃協誌, 34, 518 (昭 30).

54) J. E. Conner, Ind. Eng. Chem., 47, 152 (195 $5)$.

55) B. A. Dadashev. Truid Inst. Khim., 13, 125 (1954).

56) W. P. Hettinger, C. D. Keith, J. L. Gring \& J. W. Teter, Ind. Eng. Ohem., 47, 719 (1955).

57) G. R. Danaldson, Ind. Eng. Chem., 47, 731 (1955).

58) Heinz Heinemann, Ind. Eng. Chem. 47, 735 (1955).

59）土屋敦彥, 燃協誌, 34, 525 (昭 30).

60) V. I. Isagulyants, \& P. S. Bolov, Nefiyanoe Khoz., 32, No. 8, 64 (1954).

61) J. J. Verstappen \& H. I. Waterman, J. Inst. Petr., 41, 343 (1955).

62) J. P. Hogan, R. L. Banks, W. C. Lanning \& A Clark, Ind. Eng. Chem., 47, 752 (1955).

63) 山本研一他, 日本化学会第 8 年会譵演, 30 年 4 月

1 日。

64) 安東新午, 內田正敏, 燃料協会「石油和上びュー ルタールに関する特別講演会」30 年 11 月 2 日。

65）日石技報，7，466～531（昭 30）.

66) T. S. Laszlo, Petr. Ref., 34, No. 1, 115 (19 55).

67) W.C. Van Zijll Langhont, G. J. E. Stijntjes \&. H. I. Waterman, J. Inst. Petr., 41, 263 (19 55).

68) M. D. Abbott, G. E. Liedholm \& D. H. Sarno, Petr. Ref., 34, No. 6, 118 (1955).

69) 安東新午他，日本化学会第 8 年会䊒演， 30 年 4 月 1 日。

70) 安東新午他, 燃料協会「石油和よびュールタール に関する特別講演会」, 30 年 11 月 2 日。

71）斯波忠夫他，日本化学会第 8 年会諲演， 30 年 4 
月 1 日。

72) 仲井由之他, 日本化学会第 8 年会䟵演，30 年 4 月 1 日。

73) 神原周, 大北熊一, 工化誌, 58, 229 (昭 30).

74) 桜井俊男他，日本化学会第 8 华会偝演， 30 年 4 月 1 日。

75）宮西通可，燃協誌，34, 373，638（昭 30).

76) R. Vichiniesky \& R. Karout, Compt rend., 239, 959 (1954).

77) B.J. Reitzer \& G.G. Lamb, Ind. Eng. Chem., 47, 1239 (1955).

78) G. Leide \& A. Girelli, Rev. Combustibili, 8, 668 (1954).

79) W. M. Cunrming, J. A. Horm \& P. P. Ritchie, J. Apply. Chem., 5, 39 (1955).

80) 市川良正他, 日本化学会第 8 年会譵演， 30 年 4 月 1 日。

81) R. S. Jessup \& J. A. Cogliano, ASTM. Bull., No. 201, 55 (1954).

82) P. W. Donahue, ASTM. Bull., No. 200, 61 (1954).

83) W. F. Schoen \& A. V. Mrstik, Ind. Eng. Chem., 47, 1740 (1955).

84) 三菱石油, 研究資料, 5, No. 2, 別册 (昭 30).

85）片山寛，日石技報，7，77(昭 30).

86) H. Schildwächter, Birenn. Ohem., 36, 44 (1955).

87) J. K. Walker \& C. L. O' Hara, Anal. Chem., 27, 825 (1955).

88) M. A. Elliott, J. Air Pollution Control Assoc., 5, 103 (1955).

89) F. G. Rounds, 同上 5, 109 (1955).

90) J. M. Chandler, 同上 5, 56 (1955).

91) 重由, 茂木, 燃料協会「石油とコールタールに関

する丵演会」 30 年 11 月 2 日。

92) 小幡武三他，工化誌，58，771 (昭 30).

93）印滕英次郎，日石敁報，7，577（昭 30).

94）水谷嘉之，日石技報，7,589（昭 30).

95) 五十嵐之雄, 日本化学会第 8 年会講演, 30 年 4 月 1 日。

96) L. R. Kleinschmidt, J. Research Natl. Bur. Standard, 54, 163 (1955).

\section{潤滑油に関する研究}

潤滑油に関係した研究関係資料を整理してみると， その対象が比較的多方面に亘つていることがわかる。 大まかにいえば，組成についての分析の技術，使用面 に必要な性状の改善並びにその試験法などの研究が多 いように思われる。基礎的な地味な研究も，たとえば グリースの構造の研究もその性能との関連に於て検討 されており，潤滑作用に関係したものも少くない。特 に目立つのは，電子顕微鏡や放射性元素などの新しい 道具がよく使われていることである。紙数の関係でこ
れらの全容を記す訳にはいかないから，国内のものに ついてはやや丹念に，国外のものはその概略を述へる ことにする。

精製に関係したものでは，J，L．Tiedje 氏らゆは 脱蠟溶剤として高級くトンが優れだ性能をもつことを 報告した。田上Eら”は尿素による直鎻炭化水素分離 法の改良について述へ，赤井氏ら ${ }^{3)}$ は尿素脱蠟の溶剤 として液安の使用が有利であることを示した。 $\mathrm{A} ， \mathrm{~W}$. Francis 氏4) (溶剤抽出に液体㟶酸を使用する加圧抽 出法について報告している。 G. H. Reman 氏ら5)は 溶剤抽出に Rotating Disc Contactor t使用して良 い結果が得られることを報告した。藤田氏6)は DuoSol 抽出の精製油と抽出油とのアルミナクロマト分析 㞾行い成分分離の状態を検討した。またやや趣きを異 にするが，N.W. Furby 氏i) は残渣油の潤滑油原料 としての評価法について，C. Boelhower 氏8)らは水 添触葉によるナフテン系油の cis-trans 買性化の可能 性について検討した。

合成油の関係では松田氏らきはフェニル文はシクロ ヘキシル基をもつカルボン酸のエステル並びにその逆 エステルを合成し, それらの粘度, 粘度指数, 凝固点 などの性状について，H，Zorn 氏10)は合成したイソ パラフィン並びにェステルについて構造と性状との関 係を述へ，F. Reynaud 氏11) (高粘度合成油を得る 目的で行つた不飽和酸デェステルの重合油について報 告している。後藤田氏ら ${ }^{12)}$ は電気重合法による高粘度 油の合成を試みた。D. W. Young 氏ら13)はデェステ ル油の分子内に八ロぶン化物質を導大して引性打よ び極圧性を改善しうるとした。H. B. Fernald 氏ら14) はデチオールェステルの方が相当する酸素エステルよ り高温潤滑油として優れているとしている。同じよう な目的で，林氏 ${ }^{15)}$ はメチルシルコン油とヂェステルと の混合油についての性状を調べた。

分析に関係したものでは，従来に引続き油中の金属 元素のスペクトル分析或はポーラグラフによる定量法 についての報告 ${ }^{16)}$ が相当数あるが個々の内容について はふれないことにする。R. J. Clerc 氏ら ${ }^{177)}$ は飽和 成分の分析を質量スペクル法によつて行つている。 B. J. Mair 氏15) らは API Research Project 6 が 組成炎発表 (1938 年) した潤滑油溜分について，質 量, 赤外抢よひ紫外スペクトル分析在行つた結果をと りまとめている。A. L. Jones 氏 ${ }^{18)}$ は熱拡散法によ る藺滑渵成分の分離結果を示した。W. S. Lavine 氏:0)は新および使用油中の N-フェニルー1ーナフチ ルアミンの比色定量法について報告している。三宅氏 
ら21)は電位差滴定法による中和価測定について述べ た。潤滑系統中に生成するデポデットの分析法に関し ては P. B. Burgess 氏ら 22)の報告がある。

性状およびその試験に関係したものとして，まず粘 度の関倸では，E. Kuss 氏ら ${ }^{(3)}$ は各種の油について その構造と粘度の圧力依存性との関係について，E.

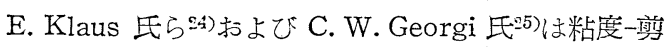
断関倸について，それぞれ述へている。粘度一温度関 倸については，U. Rost 氏(6)，K. K. Rumpf 氏济， W. Weber 氏(8)，J. Croff 氏299などの報告がある。 また [C. M. Larson 氏ら ${ }^{30)}$ は Viscosity-Temperature Index なる尺度を提唱している。木下氏 31 引は従 来に引続いてレッドゥッド粘度と動粘度との関係を調 べて実験式を誘導した。剪断下での粘度測定用粘度計 につけては，D. Tollenaar 氏ら32)，H. Markovitz

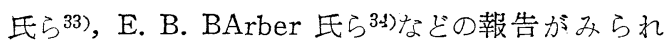
る。

酸化に関係したものでは， G. I. Kirchkin 氏ら ${ }^{35)}$ は残渣油加ら吸着分別によつて組成炭化水素の酸化に 対方る挙動を調へててる。国内では，片山氏ら ${ }^{36) は 天 ~}$ 然防止剤に関して, 八巻37ら氏は吸着分別法を応用し た組成宸化水素の影響について並びに酸化安定性の支 配因子について検討した結果について，竹下氏ら38)は 硫黄化合物の影響について報告している。ところで天 然硫黄化合物の酸化安定性一の寄与は芳香族に較へて むしろ少いということを G. I. Kirchkin 氏ら ${ }^{39)}$ が 述へている。第 4 回世界石油会議にも酸化に関孫した 興味ある報告40)が寄せられている。F. Eisenstecken 氏41》は使用中の油の変質状況を表わす指数並びにとの 応用について述べている。トランス油の酸化試験法に 関し，D. J. W. Kreulen 氏ら 49) は International Electrotechnical Commission の新法に対する批判 を行い，J. M. Ward 氏43》は高圧酸化法を検討してい る。田野辺氏ら ${ }^{44)}$ ( 過熱シリンダー油の熱安定性試験 法の反覆性，再現性などへの影響因子について報告し た。

「酸化腐蝕防止剤, 清浄肪など添加㓮関係に特許の 数が多いことは例年のと打りである。その中で，W． Lowe 氏ら ${ }^{45)} \mathrm{Ag}$ に対方る腐蝕防止㧩, J. I. Wasson 氏46)らの Ca に対する腐蝕防止剤と特定の金属を対象 としているのが面白心。松本氏ら枋は過酸化物価から ぬた合成酸化防止剈の効果について報告した。清浄性 および清浄添加剤の効果に関係して，B. Bennelin 氏日8)らの使用油中の䯚濁スラッデ粒子が熱によつて㠜 集する現象を叮寧に調へている。片山氏ら ${ }^{49}$ は L-1
法によつてDG 級エンジン油の試製を目的として清浄 剤の效果を検討した。G. H. Denison 氏ら50!は清浄 凬の効果を中心として興味ある知見をまとめている。 なお W. M. Pugh 氏ら ${ }^{51)}$ は H. D. 油の発泡性試験 法の改良について報告した。“Stop and go drive”に 於ける低温スラッデ生成を防止するための清浄剤とし て, 新型式のポリマーが有効であることについては R. L. Willis 氏ら (5)抢よび C. B. Biswell 氏ら53)の 報告がある。R. S. Spindt 氏ら ${ }^{54)}$ は低温運転のよう な條件下では NO が生成するとし，このもののデポ ジット生成に抢ける役割について述へている。早期着 火乃至は要求オクタン価増加の原因となる败焼室ブボ ジットの問題に関しては, J. B. Bidwell 氏ら5), C.

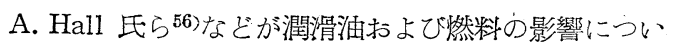
て述べている。第 4 回世界石油会議にもこの関係の報 告57が行われた。「エンジンの摩耗に関する研究とし て，片山氏ら ${ }^{58}$ は使用油中の鉄量を比色分析によつて 測定し, これからェンジンの摩耗を求める方法の桱噞 とその応用例について，Yu. S. Zaslavskiu 氏ら ${ }^{59}$ は ピストンリングに $\mathrm{Fe}^{59}$ を与えておき，油の放射性変 化を自動記録とすることによつて摩耗の研究を行つた 結果について，H. V. Nutt 氏ら60)は油の性状が摩耗 とどのような関係があるかについて，それぞれ報告し ている。固体粒子の大いさやその物理的性状と摩耗と の関倸については C. E. Watson 氏ら ${ }^{61)}$ の報告があ

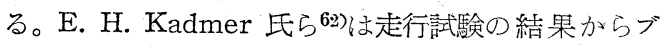
ローバイ速度が油の污孔および make-up の量と関係 づけられることを述べた。モーター油の笑用試験結果 としては国内で山本氏ら ${ }^{63)}$ 抢よび古屋氏ら ${ }^{64)}$ の報告が ある。この他，W. G. Ainsley 氏ら ${ }^{65)}$ の新しく登場 を約されている CLR エンジンについての報告もみ られる。

添加剂入りタービン油の実用成績として，中島氏66) はその使用が 20,000 時間を突破した油についておよ びその間の跔験成績について報告した。

金属加工油の関係では, W. J. Wojtowicz 氏6i) が 摺動摩擦試験法によつてその試験を行い, 笑用経験と 良く一致するとしている。

防鉝油に関倸したものとして，宅間氏68)念防錆性能 評価法として表面電位測定法を検討し, 浅原氏ら ${ }^{69)}$ も 類似の目的で金属一油滴一水滴系の水滴の接触角測定 に影響する因子を推計学的な要因の分析を行うことに よつて調べている。

焼入油の関係では，大和氏でい!鈗油にピッチ並びに その精製物を8〜10\%添加したものが優れた性能ても 
つと述へ，原氏では市販直留鉣油について冷却曲線と 主として鉱油の沸点との関係について報告した。

ここでグリースの関係に移る。グリースの組成に関 係したものをあげると，山口氏らて2)はスクアランを基 油とした Li-, Al一 およびベントングリースについて 濃化剤と而寒性，潤滑性，滴点，高温離嶈性などとの 関係を調へた。E. O. Forster 氏73)は $\mathrm{Ca}-\mathrm{Ba}, \mathrm{Ca}-\mathrm{Mg}$ 又は $\mathrm{Ca}-\mathrm{Sr}$ のような混合基グリースとすれば耐水性， 構造安定性などがよくなるとし，P．R. McCarthy氏 74)はざントン系グリースに金属石敛を加えることによ つて防錆性を改善できるとし，A.J. Morway 氏75)は 脂肪族ポリボルボン酸石跲を濃化剤として使えば thixotropic なグリースが作れるとし，また石簽基グ リースの腐蝕性を改善するために $\mathrm{Mg}(\mathrm{OH})_{2}$ を加える という試み:6)もある。グリースの構造抢よび性状に関 係した研究として，I．E. Puddington 氏77)抢よび D. W.Hotten 氏ら 78)はグリースに要求される構造という 立場から濃化蝺はどのような性状をもつべきかとう ことを論じ，W. J. Vold 氏 ${ }^{79)}$ はグリース構造を支え る力と破燷するオとについて述へ，R. H. Leet 氏80) 抢よび T. A. Renshaw 氏ら ${ }^{81)}$ は使用或は剪断によ る稠度の変化が構造の変化とどのように関連している

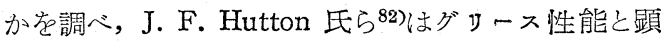
微鏡で観察した構造との関係について報告している。 G. Keil 氏ら ${ }^{83}$ (は種々の條件での見脚粘度から構造の 安定性党検討した。J. L. Dreher 氏ら ${ }^{84)}$ (見掛粘度 と稠度，石噞濃度抢よび鉣油粘度とを結び付ける関係 式を作り，これを园表にしている。，田野辺氏ら ${ }^{85)}$ も同 様な関係を調べているが結果は単純ではない。長野氏 $5^{86)}$ は特に稠度との関係について報告している。同氏 ら8うははまた低温トルクとグリース成分および稠度との 関䋆を求め, 基油の粘度が重要な因子となることなど を述へている。離漿に関する研究として,山口氏ら ${ }^{88) は ~}$ 離漿がゲルのクリープによるものであることを示し， その初期速度の尺度としての “離漿指数”およびこの 指数と稠度との関(系について報告した。檀氏ら ${ }^{89)}$ は穖 能款験による各種グッースの評価結果を述へた。この 他に試験法の関係として，H．A. Woods 氏ら ${ }^{90) は ク ゙ ~}$ リースの機械的安定性を調へる方法として Shell roll test が有用なことを，A. F. Buri 氏91》は稠度その他 の性状を調へる新装置について報告している。

無機潤滑倣として $\mathrm{MoS}_{2}$ が有効であることはすて

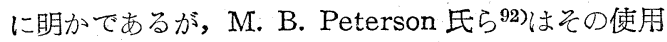
法扎よびシリカ，水，軽質鉣油などが共存する場合の 摩擦抢よび摩耗への影響を調へており，F. Weiss 氏
93)はその純度抢よび粒子の大いさが潤滑䓵果を支配ず るとしている。E. E. Weismantel 氏94)は $\mathrm{MoS}_{2}$, グ ラファイト抢よび $\mathrm{ZnCrO}_{4}$ の潤滑性とえれらを用いた 場合の fretting corrosion とについて調心，前 2 者 の有效なことを報告している。

潤滑に関係したものとしては，小原氏ら95)が鋼表面 上に作つた飽和脂肪酸および脂肪族二湓基酸エステル の累積膜につい:て静的油膜強度および静止摩擦係数字

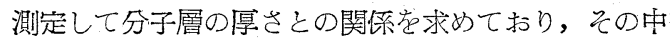
で Langmuir-Blodgett 法単分子膜と Zisman 法単 分子膜々が本質的に異なつた挙動を示すことなどを述

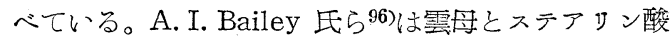
$\mathrm{Ca}$ とを使つて極圧潤滑剤の真の接触面積とすれれ強度 とについて論じている。潤滑作用への雾囲気の影響に ついて，石田氏ら 97 )は精製スピンドル油の摩擦係数 が減圧下で著しく低下する理由を調へ， S. F. Murray

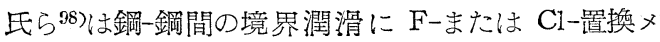
タンおよびェタンガスが效果的に衝くことをたしかめ。 ている。N. Nemeth 氏ら ${ }^{99)}$ は鉣油，合成油，グラフ アイトおよび $\mathrm{MOS}_{2}$ の使用温度限界が雾囲気学空気

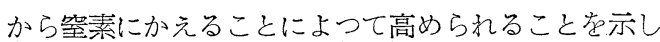
た。潤滑関䐆の研究で金属の移動或は摩耗について調 ヘる必要が起つた場合，放射性物質を利用すれば便利 である。これに関しては既述したものの他に，F．T. Barwell 氏ら 100)，F．L. Schwartz 氏ら 101)の報告が ある。

酒性乃至は極圧性の関孫では，鹿津氏ら 102) は潤滑 油の実用に関する研究としてこの関係の問題を取扱つ ている。A. Towle E-103)はギャー油の試験法, 使用中 に於ける極圧添加風の消失とその影響などについて述 ヘている。古屋氏ら 104)《潤滑油組成と油膜強度との 関係を調ざた。試験機の関孫では高橋氏105)が stickslip 型摩擦試験機を壾作した結果について，玉井氏 ら106)は振子式油性险験機を自記化した結果について それぞれ報告している。また H. Diergarton 氏ら 107)(四球䟼験機について，A.T. De Ardo 氏ら 108) はチムケン試験機について，何れも試験結果に影響す る因子について述へている。

\section{交献}

1) J. L. Tiedje 他, J. Inst. Petr., 41, 37 (1955)。 2) 土屋，田上，日化第 8 年会講演，No. 9016.

3) 赤井, 矢田, 工化, 58, 366 (1955).

4) A. W. Francis, U. S. 2, 698,276; C. A., 49, 13637h. 和よび Ind. Eng. Chem., 47, 230 (1955)。 
5) G. H. Reman 他, Petr. Refiner, 34, (9), 129 (1955).

6) 藤田, 日化第 8 年会講演, No. 9031.

7) N. W. Furby, Ind. Eng. Chem., 47, 480 (19 55).

8) C. Boelhouwer 他, J. Inst. Petr., 41, 211 (19 55).

9) 松田, 吉川, 仮谷川, 金倉, 日化第 8 年会講演, No. 9049.

10) H. Zorn, Erdöl u. Kohle, 8, 414 (1955).

11) F. Reynaud, Chimie et industrie, 72, 415 (195 5) ; C. A., 49, 9266i.

12) 後藤田, 関口, 日化第 8 年会講演, No. 9048.

13) D. W. Young 他, U. S. 2,710,877; C. A., 49, 13641d.

14) H. B. Fernald 他, U. S. 2,710,300; $O . A ., 49$, 15228a.

15) 林, 日化第 8 年会講演，No. 9050 .

16) Anal. Chem., 27 (1955) 誌上K多い。国内で 次，上妻，岡田，中肃，丸善技報，2,90 (1955).

17) R. J. Clerc 他, Anal. Chem., 27, 868 (1955).

18) B. J. Miair 他, Ind. Eng. Chem., 47, 1062 (1 955).

19) A. L. Jones, 同誌, 47, 212 (1955).

20) W. S. Levine, Anal. Chem., 27, 1019 (1955).

21）景本, 檀, 三宅, 日化第 8 年会諥演, No. 9033.

22) P. B. Burgess 他, Lubrication Eng., 11, (3), 193 (1955) ; O. A., 49, $11911 f$.

23) E. Kuss 他, Pap. 5 (V/A) to 4 th World Petr. Congress (1955); Fuel Absts., 18, (4), No. 3307.

24) E. E. Klaus 他, Lubrication. Eng., 11, (2), 101 (1955) ; C. A. 49, 7842h.

25) C. W. Georgi, Pap. 8 (VI/C) to 4 th World Petr. Congress (1955); Fuel Absts., 18, (4), No. 3482.

26) U. Rost, Erdöl u. Kohle, 8, 468, 549, 650, 718 (1955).

27) K. K. Rumpf, 同誌, 8, 308 (1955).

28) W. Weber, 同誌, 8, 643 (1955).

29) J. Croff, Rev. Inst. franc. Pétrole, 10, 463 (1955) ; Fiel Absts., 18, (6), No. 5151.

30) C.:W. Larson 他, Pap. 2 ( V./F) to 4th World Petr. Congress (1955); Feul Absts., 18, (4), No. 3745.

31）木下，日化第 8 年会講演，No. 9032 ,

32) D. Tollenaar 他, J. Colloid.Sci., 10, 151 (19 55).

33) H. Markovitz 他, 同誌, 10, 165 (1955).

34) E. M. Barber 他, Anal. Ohem., 27, 425 (1955).

35) G. I. Kirchkin 他, Neft. Khoz., 33, (7), 71 (1955) ; C. A., 49, 14308h.

36）片山，饭塚，岩郷，日化第 8 年会講演，No.9040.

37）八卷，松本滋，日化第 8 年会講演，No. 9045 ; 八卷, 松本镢, 松本滋, 同, No. 9046.
38）竹下，加藤，日化第 8 年会講演，No. 9043.

39) G. I. Kirchkin 他, Neft. Khoz., 9, (12), 60 (1954); Fuel Abst.s., 17, (6), No. 5272.

40) 例えば, F. Pass 他, Rap. 4 (V/A) to 4 th World Petr. Congress (1955); Fuel Absts., 18, (4), No. 3260. など。

41) F. Eisenstecken, Erdöl . Kohle, 8, 75 (1955).

42) D. J. W. Kreulen 他, Chem. Weekblad, 51, 77 (1955) ; O. A., 49, 7232d.

43) J. M. Ward, J. Inst. Petr., 41, 29 (1955).

44) 田野㲽, 神尾, 芝, 鉄道資, 12, 78 (1955).

45) W. Lowe, U.S. 2, 713, 557 ; O. A., 49, $15327 \mathrm{f}$.

46) J. I. Wasson 他, U. S. 2,711, 374; C. A., 49, 14316b.

47）八卷, 松本篇, 日化第 8 年会講演, No. 9043.

48) B. Bernelin 他, Compt. rend., 240, 2073, 2140, 2232 (1955).など。

49）片山他, 日石技報, 7, 120 (1955).

50) G. H. Denison 他, Pap. 1 (V/C) to 4 th World Petr. Congress (1955); Fuel Absts., 18, (4), No. 3478.

51) W. M. Pugh 他, Lubrication Eng., 11, (1), 29 (1955); Fuel Absts., 17, (6), No. 5683.

52) R. L. Willis 他, SAE J., 63, (9), 48 (1955).

53) C. B. Biswell 他, Ind. Eng. Chem, 47, 1598 (1955).

54) R. S. Spindt 他, Science, 121, 836 (1955); $C$. A., 49, 13632a.

55) J. B. Bidwell 他, SAE Trans., 63, 349 (195 5) ; C. A., 49, 16410d.

56) C. A. Hall 他, Petr. Pefiner, 34, (10), 167 (1955).

57）たとえば，W. J. Sweeney 他，Pap.2，(江/F) to 4th World Petr. Congress (1955); Fuel. Absts., 18, (4), No. 3436 など。

58) 片山他，日石技報，7，911 (1955).

59) Yu. S. Zaslavskiı̌ 他, Izvest. Akad. Nauk. S. S. S. R. Otdel Tekh. Nauk., No. 4, 43 (1955); C. A., 49, 16412d.

60) H. V. Nutt 他, SAE J., 63, (4), 64 (1955).

61) C. E. Waton 他, 同誌, 63, 6, 39 (1955)。

62) E.H. Kadmer 他, Pap. 5 (V/C) to 4 th World Petr. Congress (1955); Fiel Absts., 18, (4), No. 3480 .

63) 山本他, 三菱石油研究資料, 5, (2), 別册(1955).

64) 古屋, 森本, 小森, 丸善技報, 1, 13 (1954); 同 誌, 2, 21 (1955).

65) W. G. Ainsley他, Pap. $3(\mathrm{~W} / \mathrm{H})$ to 4 th Wor 1d. Petr. Congress (1955); Fuel Absts., 18, (4), No. 3441 .

66) 中島，日石技報，7，823 (1955).

67) W. J. Wojtowicz, Lublication Eng., 11, (3), 174 (1955); C. A., 49, 11991i.

68）宅間，日石技報，7，216 (1955).

69) 浅原, 後滕, 工化, 58, 43 (1955). 
70) 大和, 鉄逆资, 12, 216 (1955).

71) 原，日化第 8 年会諩演，No. 9029 .

72）山口，大木，日化第 8 年会講演，No. 9053.

73) E. O. Forster, U. S. 2,708,659; C. A., 49, 12 $826 \mathrm{~b}$.

74) P. R. McCarthy, U. S. 2,710,837; O. A., 49, $13642 \mathrm{i}$.

75) A. J. Morway 他, U. S. 2,710,838; C. A., 49, $13642 \mathrm{~b}$.

76) N. V. de Bataafsche Petroleum Maatschappij, Dutch 77,032; C. A., 49, 15228d.

77) I. E. Puddington, NLGI Spokesman, 19, (4), 10 (1955) ; C. A., 49, 11992c.

78) D. W. Hotten, 同恋, 19, (4), 14 (1955); O. A., 49, 11992d.

79) M. J. Vold, 同誌, 19, (4), 24 (1955); C. A., 49, 11992g.

80) R. H. Leet, 同誌, 19, (4), 20 (1955); C. A., 49, $11992 f$.

81) T. A. Renshaw, Ind. Eng. Ohem., 47, 834 (1 955).

82) J. F. Hutton 他, J. Inst. Petr., 41, 163 (1955),

83) G. Keil 他, Chem. Tech., Berl., 6, 430 (1954); Fuel. Absts., 18, (4), No. 3700.

84) J. L. Dreher 他, Petr. Refiner, 34, (6), 165 (1955).

85) 田野㲽, 河野, 山崎, 日化第 8 午会請演, No. 9051.

86）長野，山口，日石技報，7，919 (1955).

87) 長野，木村，同誌，7,923 (1955).

88）山口, 大木, 影山, NLGI Spokesman, 18, (11),

8 (1955) ; O.A., 49, 7232i

89）檀，杉，岩佐，丸善技報，2，79 (1955).

90) H. A. Wood 他, 同誌, 19, (5), 26 (1955); $O$. A., 49, 1430d.

91) A. F. Buri, 同誌, 19, (1), 38 (1955); C.A., 49, 11991g.

92) M. B. Peterson 他, U. S. Natl. Adv. Oomm. Aeronaut., Tech. Note, 3111, 19 (1954); Fuel Absts, 17, (4), No. 3379.

93) F. Weiss, Werkstoffe $u$. Korrosion, 6, 250 (19 55) ; C. A., 49, 16410h.

94) E. E. Weismantel, Lubrication Eng., 11, (2), 97 (1955); C. A., 49, 7843b.

95) 桜井, 小原, 古沢, 馬場, 日化第 8 年会講演, No. 9039.

96) A. I. Bailey 他, Proc. Roy. Soc., A, 227,500 (1955).

97) 永井，石田，日化第 8 年会丵演，No. 9037.

98) S. F. Murray 他, U. S. Natl. Adv. Comm. Aeronaut., Tech. Note. 3402, 17 (1955); C. A., 49, $9914 \mathrm{e}$.

99) Z. N. Nemeth 他, SAE Trans., 63, 556 (19 55) ; C. A., 49, 16411a.

100) F. T. Barwell 他, Pap. $3(\mathrm{~V} / \mathrm{C})$ to 4 th
World. Petr. Congress (1955) ; Fuel Absts., 18 . (4), No. 3479.

101) F. L. Schwartz 他, $S A E J ., 63,(4), 21$ (19. 55).

102）鹿津，前川，丸善技報，1，47 (1954)；2，39 (1955).

103) A. Towle, Pap. 6 (V/C) to 4 th World Petr.

Congress (1955); Fuel Absts., 18, (4), No. 3481.

104) 古屋, 小西, 且田, 岩佐, 丸善技報, 2,33 (19 55).

105）高橋，日石技報，7, 909 (1955).

106) 永井，玉井，日化第 8 年会譵演，No. 9036.

107) H. Diergarten 他, Erdöl w. Kohle, 8, 425 (1 955).

108) A. J. De Ardo 他, Trans. ASME, 77, 29 (1955).

\section{式內燃機関の䞤勢}

火花点火機関は航空用, 高速自動車用および小型沉。 用灯軽油機関に用いられているだけで，他はジィーゼ ル機関が用いられている。わが国では航空用ピストン 穖関は分解修理老行つているだけで新製はない。ブロ ーダウン型排気タービンとの複合機関である米国ライ 卜社のターボサイクロンの修理が本格化した位で，大 して眼新らしいことはない。世界的にも進歩改良はタ ーボジェットやターボプロップに向けられ，ピストン 機関としては耐久性の向上に努力されている位である。 軽自動車用は 2 サイクルが非常に多くなり，始動性， 出力その他非常に改良された。自動車がンリン機関で は小型用の $1,500 \mathrm{cc}$ 級が各社とも大体 $50 \mathrm{HP}$ 以上に性 能向上された。アメリカでは高速短行程頭上弁高圧縮 比のV型 8 気筒機関が主流となつている。

ジィーゼル機関はごく小型を除き過給が常識となり 2 サイクル穖関でも排気タービン過給が進んできた。 1 万队級までの船用主機は全部 2 サイクルジィーゼル といつてよいが，ほとんど排気タービン過給が行われ るようになり，それも従来行われてきた升排気単流掃 気方式 2 サイクル機関だけでなく，横断掃気方式のも のまで実用化されてきた。また戦後始めての三井 B\& W950 V BU600Hなどの艦艇用主機ジィーゼル機関が 作られ，2サイクル䍩働過給方式により，重量，大き さ，取扱，保守とも，戦前のものよりはるかによくな つた。4 サイクルジィーゼル機関はますます高過給に なり，またますます小型高速のものまで排気タービン 過給器が使われるようになり，そのため排気タービン として内向輻流タービンも実用され出し，その製造法 
なども一体精密鋳造の使用などの研究がされた。航空 用にはループ掃気式 2 サイクルジィーゼルと多段軸流 圧縮機多排気タービンよりなるガスタービンとを無段 変速機構でつないだナピヤ社の 1 マードII 型複合機関 が実用され，150gr/P の败費を実現した。しかし複 雑で将来主流になるとは打もえない。自動車用ジィ一 ゼル機関も重自動車より次第に乘用車なぞの高速車用 にも使われはじめ，また民生ジィーゼルの VD 型弁 排気単流掃気 2 サイクル機関が市販された。また小型 化とともに建設機械用，大型バス，トラック用として $200 \mathrm{PP}$ 級のものもましてきて，また鉄道のジィーゼル 化もかなりすずんだ。小型沉用機関の分野にも従来の 蒸発冷却横型ジーゼル機関以外に，ドイッなどで広 く用いられている空冷ジィーゼルが問題になり，クラ ンク室圧縮弁排気単流掃気式のスティール空冷ジィー ゼルの国産化が始められ, また農林省の研究費で簡単 なクランク室圧縮ループ掃気式空冷ジィーゼルが試作 された。

燃料としてはガりリンはますます高オクタン価がソ リンの供給が要求され，ジィーゼル機関では粗悪然㩽 の使用が一般になり，ライナ磨耗やいわ的るバナジュ ームアタックなどが問題となつてきた。

\section{ガスタービンの進展}

\section{1. 世界のガスタービン界の動问}

蒸気タービンも最近は高圧高温化し，その設計には 翼の空力的研究成果を取り入れるようになつたので， 熱効率は 30\% を突破するようになつた。ジィーゼル エンジンも排気がスタービン過給器の採用によつて, 熱効率は 35\% 垟するようになつたし，シリンダ磨 耗の問題は多少あるにしても，C重油の使用が次第に 本格化してきたので, 粗悪燃料が使用できることを売 物にしてきだガスタービンの影が薄くなつてきたこと は否めない。しかし，水型て大馬力が出せるとか，冷 却水が不要であるとか，振動が少ないとかの特徽は依 然としてあるので, 熱効率が稍低いとか, 低級燃料, 特にヴァナジウムの含有量の多い燃料の使用について はまた充分の見透しがついていけいなどの欠点はある にしても，用途次第では愛用できる土ンジンである。 ガスタービンの老舗であるブラウンボべリ社は依然と して多くのガスダービンを受註しているというし，イ ギリスフランスなどては小型がスタービンの進出が 目立つている。このような $1,000 \mathrm{PP}$ 以下の小型ガスタ
ービンは熱効率の点て問題にならないと考元られてい たが，ポンプ用，発電用などに多くの用途を見出して いるのは，このエンジンの手軽さが使用者の好むとこ ろとなつているのではないかと思われる。わが国では 小型がスタービンに対する関心がまだ薄いようである が世界のこの傾向には注意を払う必要があろう。

船船推進用の主機として 15,000 時間もの長い間“オ ーリス”号に積込まれて実用実験を重礼ていたトムり ン・ヒューストン会社の $1,200 \mathrm{PP}$ のガスタービンは寒 用性ありと認められたらしく, 他の 3 台のジーゼルエ ンジンと共に陸揚げされ，その跡に 1 台の $5,500 \mathrm{PP}$ の ガスタービンが積込まれた。今後はこのエンジン1本 て航海しょうという世界で最初のガスタービン船がで きた。後進のためには流体接手が採用されている。

ロールス・ロイス社の RR500 型 5,000HP ガスター ビンは英海軍の駆潜艇グレー・グースに積込まれて実 験が継続されているようである。

イデリスのガスタービン機関車 2 台は依然としてパ ッディントンーブリストル間の急行列車を电いて，正 規のダイヤで毎日運転されている。がスタービン機関 車が成り立つかぼうかは長い間の実用実験を経ないと 分らないというのがイギリス人の考光方のようであ る。運転経費や維持費がどうなるか, 線路の痛み方が ぞうであるかなど長期間の統計的数字を基にして検討 せねばならないからであろう。

世は次第に原子力時代に入りつつあり，陸上，海上， 空中の交通機関の推進動力も原子力エンジンになろう とするきざしがみえ始めた。この原子カエンジンの形 態は現在の進歩の段階ではレシプロ型とはなり得ない で, 原子炉をボイラまたは燃焼器代りとする蒸気ター ビンまたはガスタービンになるであろう。原子核融合 反応を自由に起すことができかつ制御することができ るようになれば，水素やリチウムを燃料とする内燃機 関が現れるかも知れないが，当分は原子炬から熱を鿓 うタービンの形式が行われるであろう。従つて, ガス タービンは原子力時代にも生命を保つことができるに 違いない。ことに航空機用としては絶対である。

2. わが国のガスタービンの現状

わが国では現在十数台のガスタービンが完成または 建造中であるが，大部分は製造工場において運転試験 中の段階にあり，3台が実用実験中である。この内開 放サイクルが 10 台, 密閉サイクルが 1 台, 自由ピス トン型が 2 台ある。それらの要目は第16，第17表に示 すと抢りである。

戦後わが国のガスタービン研究の推進力となつた 1 
第 16 表 開放および密閉

装置播号

$$
1
$$

2

3

4

5

製 作 会 社 石川島芝浦タービン三井造 船三菱日本重工三菱造船 石川島重工

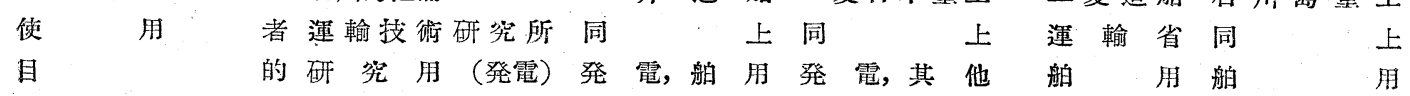

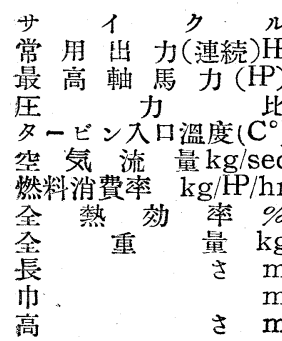

$\begin{array}{rc}1 / \mathrm{LP} / 1 \mathrm{RE} & 2 \mathrm{SC} / 2 \mathrm{P} / 1 \mathrm{RE} \\ 2,210 & 2,500 \\ -\overline{15} & 3,200 \\ 5.15 & 10 \\ 550 & 700 \\ 18.5 & 12 \\ 0.281 & 0.199 \\ 22.5 & 31 \\ 103,300 & - \\ 7.26 & - \\ 11.60 & - \\ 4.68 & -\end{array}$

$1 / \mathrm{LP} / \mathrm{E}$

$\begin{array}{rr}\mathrm{LP} / \mathrm{E} & 1 / \mathrm{LP} / \mathrm{E} \\ 450 & 470 \\ 500 & 500 \\ 3.5 & 3.5 \\ 650 & 650 \\ 6 & 6.3 \\ 0.4 & 0.395 \\ 16.2 & 16 \\ 22,000 & 16,120 \\ 7.0 & 7.0 \\ 5.0 & 5.0 \\ 3.5 & 3.5\end{array}$

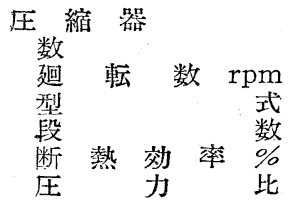

$1 / \mathrm{C}$
2,000
2,200
3.0
650
22
0.480
14
7,700
4.5
1.6
2.1

\begin{tabular}{lrrr} 
高压 & 低圧 & \multicolumn{1}{c}{ 高压 } & 低厓 \\
1 & 1 & 1 \\
6,000 & 6,000 & 18,500 & 17,000
\end{tabular}

軸流 軸流軸流軸流十遠心

軸

5,500

$\begin{array}{rrrr}87 & 85 & 92.5 & 80 \\ 2.08 & 2.50 & 3.23 & 3.10\end{array}$

1
10,000
軸
流
19
80
3.5

1
9,000
軸流
16
82
3.5

中間冷却器

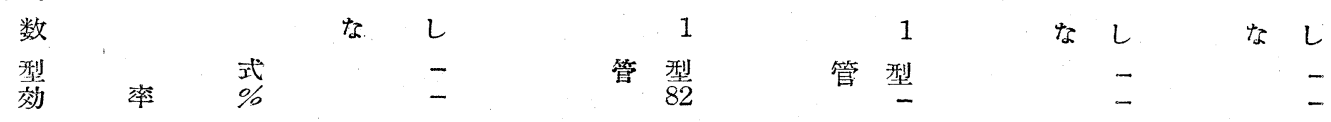

燃 燒 器

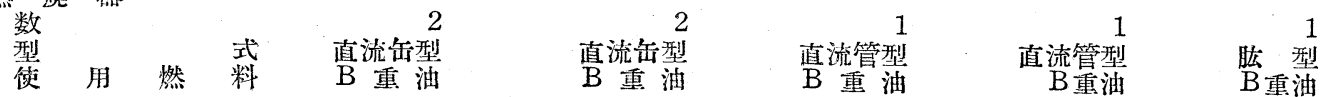

再熱 器
数

圧縮機用ターピン

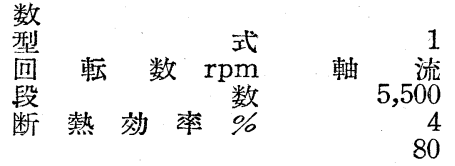

䟖力タービン

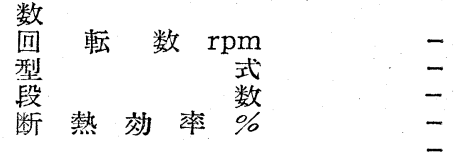

熱恋換器

型

率 $\%$ 式的
管

直流缶型

$\begin{array}{cr}\text { 高压 } & \text { 低压 } \\ 1 & 1 \\ \text { 軸流自 由渦型 } \\ 8,500 & 17,000 \\ 4 & 4 \\ 90 & 84\end{array}$

低 圧

軸 流

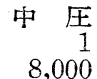

軸流自由洞型

4
87

鮱 付 板 型

管 型

管 型 
型方スタービン

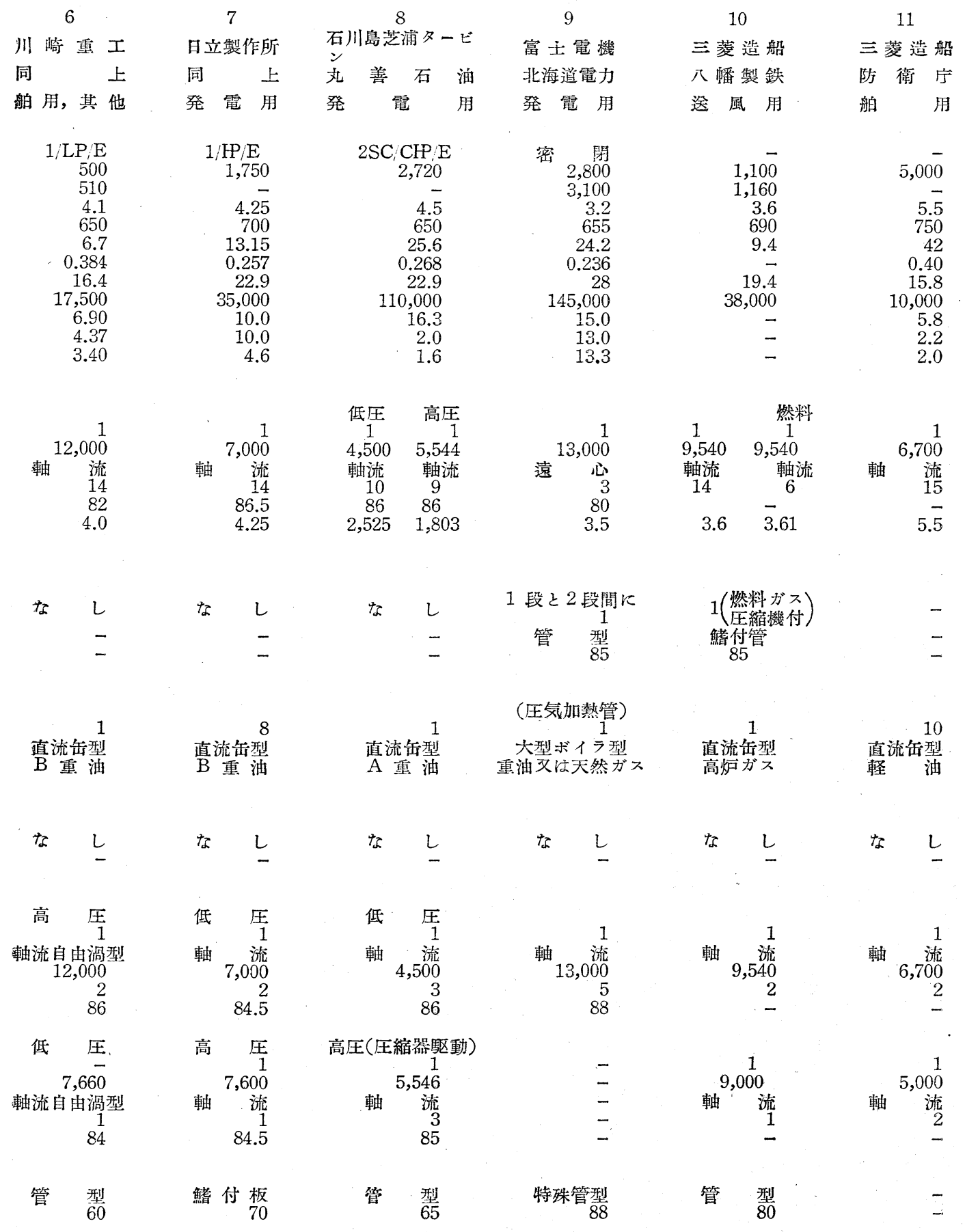




\section{第17表 自由ピストン型方スタービン}

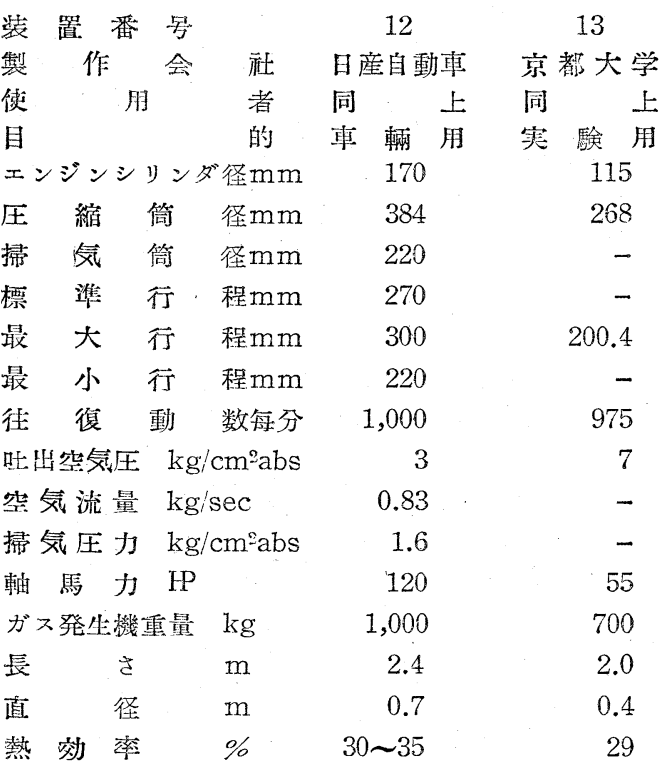

号機は，その運転中に各部の詳細な測定が行われ，て れによつて精密な解析が行われた。その結果このがス タービンの設諨が戦時中のものであるため, 性能があ まりよくないことが分り，今後の研究の進め方に重要 な示唆を与えてくれた。現在は冬期渴水時の電力不足 存補うための自家発電用として使用されこれによつ て長期間の赛用実験を行つている。

2 号機はケーシングが氷冷却され，軸が油冷却され るという変つた構造のもので現在高圧低圧両部分とも に完成し，製造会社において運転実験中である。

3 号機は 3 軸型で出力は中圧タービンによつて得ら れる構造である。翼の構造など理論に忠実に彷つたた め, 圧縮機, タービンともに断熱効率が大変よい。目 下社内で寒験運転が行われている。

4 号機は航海訓練所の練習船北斗丸に搭載され, 舶 用ェンジンとしての適性を長時間の実用実験て試験さ れている。

5 号機は性能運転および約 200 時間の工場内での耐 久運転を終え，船に搭載されて実用実験が行われるの を待つている状況である。

6 号機は従来の蒸気タービン式の設計法によらず, ガスタービンの特徴を活かした小型軽量のものであつ て, 工場内で一応の性能運転を行つたが, 熱交換器を 有り合せの大きなものを使つたために不格好なのでそ の改造を行つている。

7 号機は昨年完成，一応の社内運転を終つたという 段階のようである。
8 号機は昨年完成, 製作工場で一応性能運転を行つ た後, 丸善石油の下津工場に運ばれ，本年 1 月初めに 据付完了, 発電用としての実用実験が開始されてい る。

9 号機は日本での最初の密閉型がスタービンである が，最近完成し，目下試運転中である。

10号，11号機ともに目下建造中というところであ る。微粉崖を然焼させるガスタービンは米国でも穖関 車用として 5,6 年前から研究に努めているが，まだ策 用化するには至つていない。

わが国では運研で小型輻流タービンをもつた小型炭 然ガスタービンを作つて輻流タービンの特性を調へる とともに炭燃がスタービンの諸間題の解決に努力して いる。

日立製作所でも微粉炭燃焼に関して以前的ら関心を・ 示していたが, 最近サイクロンバーナの開発に努力し ているようである。

自由ピストン型のガスタービンは 2 種類作られてい る。12 号機は一䝫年完成し，工場で試運転した結果 或る程度の成功を収めたようであるが，会社の方針の 変更によつてこの研究は中止された。フランスでは車 輛用に使用されて成功しているようである。振動が少 ないので車輛用ジーゼルェンジンに代るものとして実 用化に努めてもらいたい土ンジンである。

13 号機は大学における実験用で, 王搾空気て备し, 然焼ガスはタービンを䞟さないで大気中に放出してい るガスプロデューサーである。

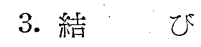

わが国で大型のガスタービンを作ろうとすると，ま だ材料的な制約を受けることが多いので，ガスタービ ン用而埶材料の製造技術を確立することが緊要であ る。またガスタービンを信頼性のあるものとするため には長時間の実用実験を必要とするが，製造会社の負 担に抢いてこれを行うのは経済的に困難であるから， 使用者との間で適当な経費の分担の下に共同研究が行 われることが望ましい。

然料の灰分によるタービン翼の污れの問題や，腐蝕 の問題など，ガスタービンの実用化をはばも諸問題も 早期に解決しておか子ばならないので，タービンメー カ, 然料会社などと共同研究で運研はこの難開題と取 り組んでいる。

多くのガスタービンが試作されたが，耐久性や信頼 性が確認されていないので，今は華々しくなくて骨の 折れるこの種の実験の段階にきているものと私は思つ ている。 


\section{內燃機燃料の趨勢}

昭和 30 年度における内燃機然料のトピックは第 5 回世界石油会議および SAE 50週年会などに提出され た幾多の論文が代表的のものであろうが，その他の発 表論交などに散在するものから 1 ケ年の回顧とその趨 勢について考察を行うこととする。米国鉣山局の発表 1)になる 1953 年度世界主要国石油品種別需要率平均 とわが国のとれを比較すると第18表のと打りとなる。

\section{第18表 世界平均石油品種别需要率平竘亡} わが国の比較

品 種 ガソリン 灯油 軽油重油潤滑油

$\begin{array}{lllll}\text { 全世界 } \quad 43.2 \% \quad 5.9 \% \quad 20.0 \% \quad 29.0 \% & 1.8 \%\end{array}$

日 $\quad 25.9 \% \quad 4.3 \% \quad 6.4 \% \quad 58.5 \% \quad 4.8 \%$

上にみるとおりわが国石油製品の需要特徵は焚燒燃 料として便用されるものが多いため使用効率の高い溜 出油, 特に軽油, ガソリンの需要が少く, 重油のそれ が著しく多いことである。重油の輸入税，消費規整令 による重油使用制限が行われたとはいえ，揮発油税， 最近論議されはじめた軽油税などの関係によるため, またはえの他の原因によるが依然として 30 年度も重 油の需要の多いことは第 1 図のと抢りである。

\section{第 1 図 昭和 29,30 年度月别石誼製品需要量}

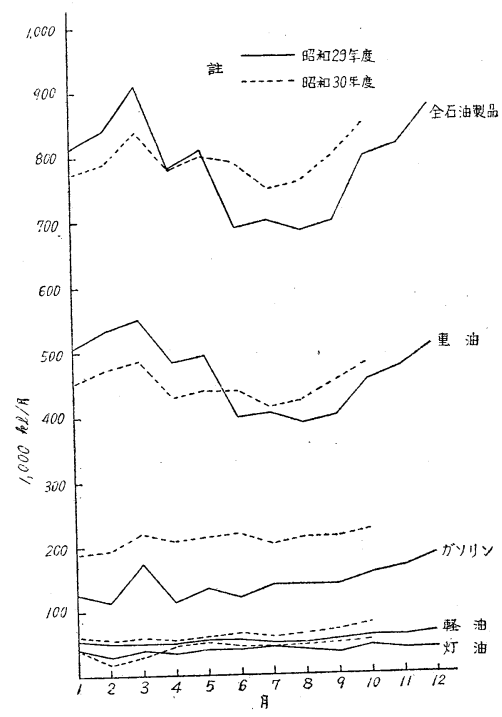

今後の需要趨勢さ国家防衛の強化, 石油化学の具体 化と今後の国家政策によつて左右されるものが多いた わとの予測は困難である。

1 電着エンジン燃料

\section{1-1 航空ガソリン}

戦後始めて防衛隊の 100/130 航空ガソリンの購入が 行われ，国内一部石油会社でアルキレーションその他 による航空がソリン製造計画が発表された。米国軍部 スポークスマン2ににより将来 100/130 航空ガソリンは 軍規格から抹殺され，115/145 航空がソリンが代表的 のものとなるだろうと発表されたことなどが特筆す心 き事柄である。

1-2 自動車ガソリン

29 年末三菱石油から活損防止剂入りがンリンの発 志されたのを端緒として 30 年春からシェルより，30 年末からその他数社よりこの種がソリンの販売が行わ れた他，日本石油よりオクタンレースの端が発せられ たなど実質的品質の競争が開始され，各社高オクタン 製造装置がいずれも順調な運転に大つたから今後次第 にオクタン洒は向上されるだろう。一昨年実験車によ るガソリンの実用性能䳝験が三菱石油 ${ }^{3)}$ によつて開始 されたが 30 年春エチールコーポレーションより実験 車の貸与を受けて各石油会社が順次実用実験を行いそ の経験により今後ますますこの種研究実験による品質 の向上がはかられるだろう。

自動車エンジンについてはロシアの気筒別気化機附 エンジン， E. I. du Pont のリンコルン乗用車学使用 した噴射エンジン4),MAN のガソリンより軽油まで使 用可能な特殊ジーゼルェンジンら゙などによる劣質がン リンの高能率化使用ということも考えられるが，現実

\section{第 2 図 米国における自動車エンジン圧縮比と ガソリンのオクタン佂傾向}

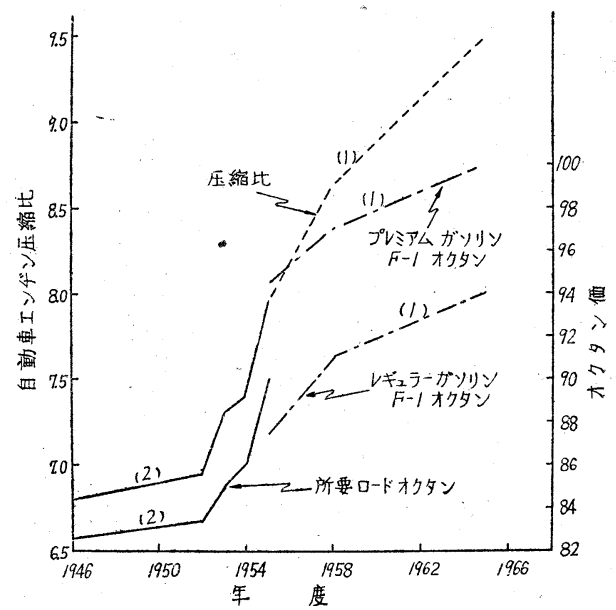

注 (1) Petr, Process, 10,3, March, 1955. (2) Oil \&Gas J. その他上り各本均値を示す 
第 3 図 ガソリン製造法の推移

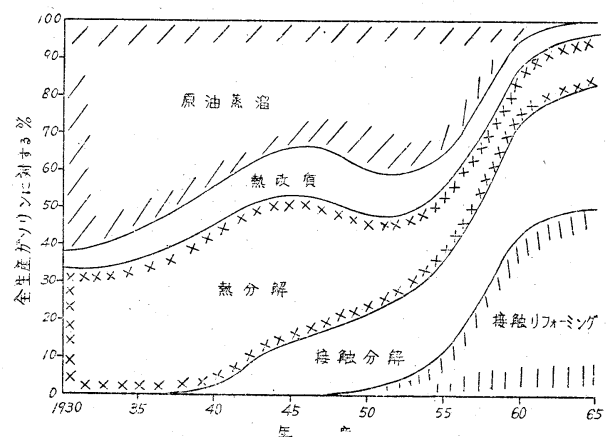

Marshall Sittig, Wayne Warren,

Pet. Ref., 34,9, Sept. 1955.,

的には依然として圧縮比の増大をはかり高オクタンガ ソリンに期待されることは第 2 図のように予想されて いることからも明らかで，その製造法については第 3 四のような予想が行われている。製油法の複雑化にと むない混合がりリンのォクタン価の予想が必要となる がそれについては W. F. Schoen氏ら ${ }^{6)}$ が原料ガソリ ンの F-1, F-2 をより正確に計算する法を発表した。 製造法の差違による Sensitivity は当然起ることであ つて Sensitivity とロード・オクタンの関係について はV. B. Guthrie氏う) は第4図のような関係を発表し た。他方自動車の起動性も重要視され米国においては $90 \%$ 点 $300^{\circ} \mathrm{F}$ 内外のも ${ }^{8}$ のか 30 年始め頃から Esso Standard, Gulf Oil Corp. により発売されるように なつた。研究の中心は依然としてェンジン回転数, 便 用時間による性能の変化とアイドリングの場合に起る 停止問題である。

1-3 沉用電着エンジン燃料

農耕用 小型漁船用として灯油および軽油を使用す るこの種のエンジンの発達にともないこれらの燃料と して特別の製品が徐々に考慮されるようになつた。30 年度通産省沉用エンジン審查に当り始めて使用然料の オクタン価の考慮が払われたことは特筆すべき事柄で あろう。

1-4２サイクル電着エンジン燃料

モーターボート，バイクェンジンなどその他でく一 部特殊のものに限られるが，潤滑油混合によるガソリ ンのオクタン価低下 ${ }^{9}$ の関心が深まりこの種の研究に 着手された他，国内においいて三三の混合用特殊潤滑油 の販売が開始された。

2 ジーゼル・エンジン然料

2-1 高速ジーゼル然料

国内バス事業の発達にともない大型バスにジーゼル
エンジンの使用増加，小型漁船のジーゼル化，茟設機 械の使用堌加なぞにともなつて軽油の需要が堌加した がその生産量はこれにともなわず相当量の製品輸大が 行われた。

将来の傾向として細国鉄ローカル線のジーゼル化， 去る 11 月兵器工業会より行われた答申ど抢り防衛用 車輛のジーゼル化が促進されることになれば軽油の不 足はますます増大することとなりその対処策が必要と なるだろう。

品質的には国内では大部分直溜品を使用しているか ら羑し当りは問題はないが，需要の増大にともない或 る程度の品質低下は不可避となるだろう。たとえば米

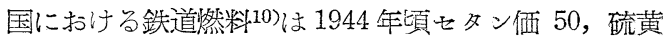
分 $0.1 \%$ 以下であつたが近年せタン価 45 以下，疏黄 分 $1.2 \%$ 以下のものも便用されるに至つたと伝えられ ている。

分解軽油の製品化が次第に增大するにともない只の 精製法も問題となりたと光ば $\mathrm{KOH}, \mathrm{NaOH}$ の濃厚液 を使用方る Dualayer Treater ${ }^{111}$ らの新洗滌法また は各種添加剤の便用が次第に増大するであろう。

\section{2-2 低速ジーモ゙ル燃料}

舶用エンジンにいわわる劣質重油と称将られる在来 の焚燒量油がこれに使用されることが世界的に一般化 される傾向となつてきた。そのためにェンジンの磨 耗，異状燃焼なぞの故障原因についての研究が活潑と なり灰分，スラッジなどの影響が次第に大きく採りあ げられるようになつた。

スラッジの定量法としては T. Stanford Tutwiler 12)らにより新らしい测定法が発表された他，更油の連 続清浄機として Sharple's recycle Nozljector ${ }^{13)}$ が 米国において実用化された。なお添加汫使用による実 用性能向上化の研究の活潑であることは他の燃料之同 様であるが，元来重油の価額は低廉であるため無機水 溶性添加隹の使用も考慮されその基本研究として水湿

\section{第 4 図 CFR オクタン価とロードオクタン価}

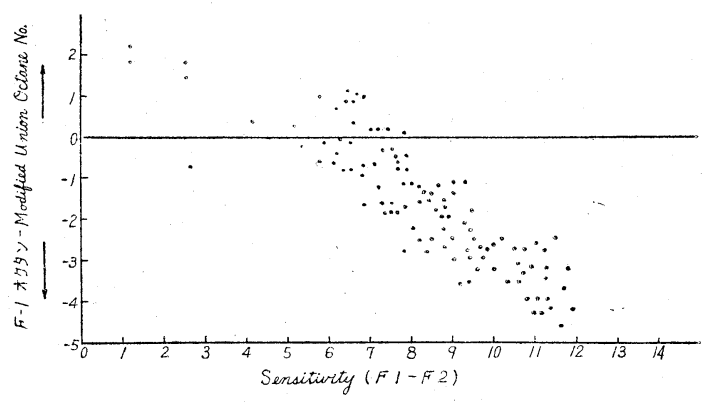

V.B. Guthrie, Petr. Processing, Feb., 1955. 
第 5 図 米国における航空燃料需要

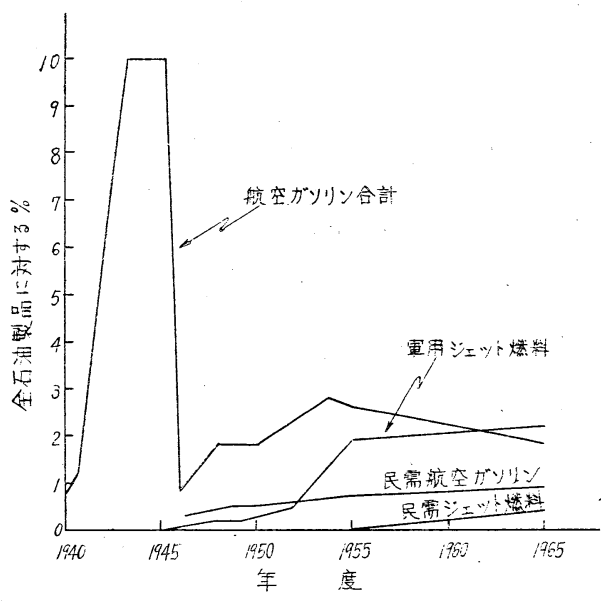

Petr. Process., 10,3, March, 1955.

合燃料についてェンジン勃率の変化の研究が I. Cornet氏ら11)により行われた。

黑油の品質は年々低下寸るだろうから将来之もます ますその実用性能についての研究は盛んになるだろ う。

3 ガスタービン燃料

3-1 航空ジェットエンジン然料

昭和 29 年度より駐留米軍の JP4 の一部国内供給 が開始されたが，30 年度に抢いてさらに少量の JP5 も供給されることとなつた他，防衛隊の JP4 の国内 購入もありジェッ下燃料の国内生産も徐々に本格的に 考慮されるようになつた。

米国における航空燃料需要予想は第 5 図 ${ }^{15)}$ に示すと おり漸次がソリンからジェット然料におきかえられる こととなつているが，その量は全石油製品に対して数 \%に過ざない。しかし作らわが国石油製品の全需要量 と米国のそれとの対比之国家防衛需要量について考え た場合，将来わが国に抢けるジェッ下燃料の量産につ いては相当の困難性が生ずることであうう。

近来米国にお打るジェット燃料についての研究は低 気圧，低温の高空に扎いて音速以上の航空時におおる 各種然焼性能の研究が中心となりつつあるようでたと えば W. T. Olson 氏 ${ }^{16)}$ は高空高速時におりる然焼効 率は揮発性のよい直鎖パラフィン系の蹨料がよいと報 している。燃焼バーナの型式は次第に蒸発燃焼型のも のに推移しつつある模様であるから，然料はますます 枩安定性のよいものが要求されるようになりその精製 法は従来の洗滌，抽出法からアルキレーション或いは 水素添加法などの新らしい方法の研究が将来盛んにな
るであろうし，また消泡，乳化防止，低温流動性など についても種々の研究と考慮は払われるようになるだ ろう。

3-2 自動車ジェット燃料

自動車エンジンのガスターービン化はま主実用化に至 つていないようであるが，フォード，クライスラー， モ゙ネラルモータース17)などでの研究は活潑であつて 1960 年代にはこの種エンジン附自動車が販売される だろうと伝えられている。このようなこととなれば灯 油, 軽油の増産についてはますます研究を要すること が多くなるだろう。

3-3 定置用, 舶用ガスタービン燃料

北斗丸および汐路丸の補助エンジンとしてガスター ビンェンジンが設置され，その研究についても実用実 験の域に達したがいずれも灰分にの他による堆積物に 上る効率の低下が問題となり,これらの問題の究明を 解決のため運輸技術研究所を中心としたエンジン製作 業者, 製油業者の共同研究グループが結成された。

世界的にはアラビアその他の荒無地の発電設㣁, 舶 用エンジンとして徐々に実用化されるようになつたた めガスタービン燃料油として重油の硫黄分, 灰分など に関する研究がますます活潑となつた。

米海軍においてはこの種の Cosag Power Plant 用 燃料油について研究中とのことで第18表のとおりの規 格案が提示された。

\section{第18表 Cosag 燃料 パイロット規格}

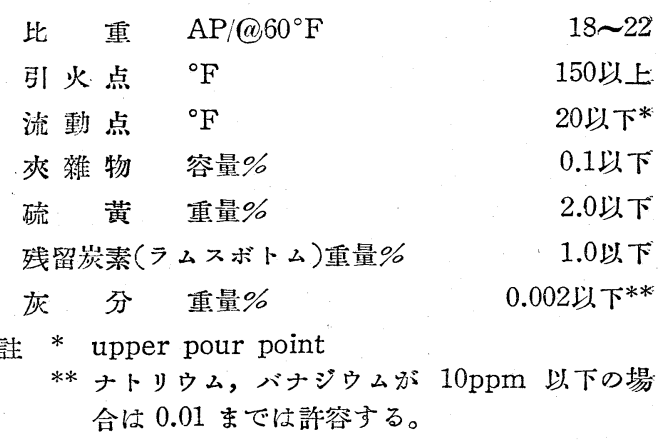

要するにこの種エンジン然料としては燃焼堆積物を の他が実用上問題となることは明らかであるが，それ らの事項もエンジンの大きさ，用途その他により寒用 上の影響に相当の差違が生ずることであろうから実用 規格その他については今後の研究に待つべきものが多 々あるだうう。

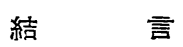

以上昭和 30 年度における大略の推移と今後の趨勢 
についての概観を行つたのであるが，陸上，海上の交 易の増大にともなう各種機関の発達と石油化学の進歩 にともなう製油法の進歩などにより新時代に対応する 優良内燃機燃料の製造並びに選定ということはますま す複雑となるものと思うが，ガソリンについてはます ます高オクタンのものが要求され, 灯油, 軽油につい てはより安定な製品の量産, 重油についてはいわゆる 不純物の少ない製品が要求されるようになるのではな ふろうか。また品種別需要比についてはいずれ大きな 変化が起ることも予想されその方向性を䛊らないため には単なる行政的国家政策によらず根本的に科学的研 究による国家政策の樹立少要求されることとなり，ま すます研究の必要が增大するであろう。

\section{交献}

1) World Petroleum, Dec. (1955).

2) Aviation Week, Oct. 10 (1955).

3) 三菱石油, ジーゼル自動車 5 卷, $9,10,11,12$ 号 $9,10,11,12$ 月, 30 年。

4) Petroleum Refiner, 34, No. 10, Oct. (1955).

5) Petroleum Week, (1955).

6) W. F. Schoen, et al., Ind. Eng. Ohem., 47, No. 9, Sept., 1955.

7) V. B. Guthrie, Petrolewm Proc., Feb., (1955).

8) Petroleum Proc., Vol. 10, No. 3, March (195 5).

9) 岸野鉄夫, 日本化学会東京艾部秋季研究発表会。

10) W. H. Hubner, Diesel Power, 132, No. 8, Aug., (1955).

11) C. A. Duval, et al, Petrolewm Refiner', 34, No. 9, Sept. (1955).

12) T. S. Tutwiler, Chem. Week, 77, No. 15 , Oct. 8 (1955).

13) Diesel Power, 33, No. 10, Oct. (1955).

14) I. Cornet, et al., Ind. Eng. Chem., 47, No.10, Oct. (1955).

15) Petroleum Proc., 10, No. 3, March (1955).

16) W. T. Olson, Trans. ASME, 77, No. 5, July (1955).

17) Petroleum Week, 19, Aug. 26 (1955).

\section{汽力発生と焚燒法の䖯勢}

本項目については全般的にみて昨年度に比べ大きな 変化はないが，重油楚きボイラの設置制限に関する法 令公布の影響と, いわゆる松永構想に基く電力設備近 設化計画案発表の影響が遂次具体的な形で現われ始め たようである。すなわち重油炎きボイラの新設が困難 になつたため, 各種メカニカルストーカーがさらに改
良せられたすがたをもつて再び増加の動向を示し，ま た微粉崖然焼が従来の使用範囲をさらに拡大せんとす る傾向を呈し始めた。小容量でュンパクトな微粉炭然 焼装置も現われてきだ。

電力設葻近代化計画案の発表により影響它うけた電 源開発方針は，高能率最新鋭火力の建設に重点をおく 結果となつて現われ，火力技術界はとみに活気を帯び てきた。今年は欧米に扎いても新鋭級とされている三 重, 刚田, 多奈川, 千桨の 4 輸大プラントの建設に続 いて多くの最新鋭級プラントの新設阡画が発表をみた が，前 4 者に続くものの大部は国内メーカーにより受 註されることとなつた(第19表参照)。このことは終戦 後 10 年, 漸くわ加国のこの方面におけ尚挍術が欧米 の進歩に追随し得るに至つたことを示すものといえよ j。

\section{第19表 新建設および計画中の新銳火力発電所}

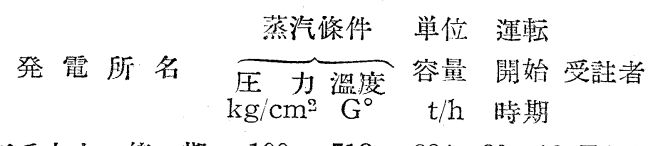

三重火力・第一期 $100 \quad 513 \quad 284 \quad 30-12$ F.W. 多奈川火力 $103538254 \quad 31-3$ C.W. 对田火 力 $103 \quad 538 \quad 254 \quad 30-12$ C.W. 千葉火力・第一期 $127 \quad 540 \quad 435 \quad 31-12$ C.W, 三重火力・第二期 $110 \quad 540 \quad 260 \quad 31-12$ 国内 新 東京・第二期 $105 \quad 513 \quad 280 \quad 32$ - 12 国内 千葉火力・符二期 $139 \quad 540 \quad 435 \quad 32$-12 国内 大阪中央火力 $179 \quad 569 \quad 543 \quad 33-10$ 米国 新宇部火力 $\begin{array}{lllll} & 95 & 520 & 280 & \text { - 国内 }\end{array}$ 大 村火 力 $88 \quad 510 \quad 284 \quad$ - 国内 新名古屋火力 - - - - - 米国 追補

旭硝子牧山工場 $140 \quad 525 \quad 75 \quad 31-1$ 国内

これらの他に今年度におおて特に目立つたもの存拾 つてみると, 高温高圧の特殊ボイラとして横山工業に よる VKW ベンソンボイラ 2 基が旭硝子牧山工場に 建設され運転を開始した。発電用として建設された特 殊高圧ボイラとしては三菱化成黒崎工場のレフラーに 続くものである。発電用汽㟀の蒸汽條件が高温高圧化 の一途を辿る現情勢下に唟いて，自然循環式に対する 蒸汽條件にある限界が考へられる以上，ベンソンボイ ラのわが国における出現は将来に対するテストケース としてきわて意義深いものがある。

高温高圧パワプラントの建設が次々と行われるの で，給水処理に関する高度の技術が運転接術者にとつ て目の前の問題となつて来，ヒドラヂンによる溶解酸 素除去，アンモニャ或はアミンによる $\mathrm{pH}$ エントロー ルなどが実施に移され始めてきた。またこの種大容量 
汽缶に抢いては高能率化の線に沿つて $\mathrm{ACC}$ は $\mathrm{ABC}$ となりつつあり.炬内監視, 煤聇監視, 水面計監視な どを工業テレビによつて行う所もみられ始めた。

汽缶の自動制御に喔連し，微粉炭装置にチューブミ ルを使用のものではるる給炭量のコントロールが困難 な閭題として残されてきていたが，ミル出入口の温度 による新しいコントロール方法が考案せられ或る程度 の効果を収为ている。この他ミルの騒音を利用する方 法も実用試験の域に入つたようである。

近年低質炭の大容量発電への利用が再び熱心に検討 され始めたが，今年に至つて常盤産低質炭使用の大発 電所が具体化してきたことは特筆すべきことであろ う。新宇部火力，大村火力などの計画も低品位のもの を目標とした計画といわれている。

炎焼法に関しては特記すべきものは見当らないが， 微粉炭焚き大型発電用ぶイラて近年新設されたものを みるとタンゼンシャルファイヤリング式となつている ものが多小。このことは注目玄へきことであろう。他 に興味ある関連事項としては，日立において大掛りな サイクロンフアーネス試験定実施したことと, 横山工 業が湿式燃燒炉の大規模試験を行つたことなどがあけ られる。

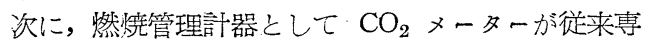
ら用いられていたが，重油混焼なとの傾向が增すにつ

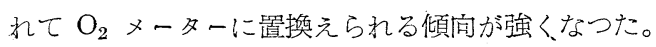
これれ燃焼がス中の $\mathrm{O}_{2}$ が燃料の種類に比較的無関係 に空気過剩率を表示し得るからで, 近年に至つて優秀 な $\mathrm{O}_{2}$ メーターが出現したのも一つの理由である。

石炭炎き大容量プラントで厄介な問題の一つに灰処 理の閒題があるが，これに光明を与えるものとしてフ ライアッシュのポゾラン材としての利用が近年大きな 話題となつた。すでに宇部興産, 宇部窒素などでは数 年前よりこれを商品として販売しているが，事業用火 力発電所においても, 尼二, 戸畑, 宇部, 名港, 新東 京なぞコットレル集磨器を設置のところではポゾラン 材としてのフライアッシュを採取する本格的プラント を建設するに至つた。

スラグ，バードネスト対策は古くから問題となつて いることであるが，近年相当効果の期待できる添加剤 が現われてきたようで，好成績を示したという報告が 比較的多くみられるようになつた。スートブロワも高 性能化し段多多く使用せられるようになつてきてい る。

以上の他に, 大容量火力発電所などでは遠隔操作電 気着火装置の設置, 集歴装置としてローテミューレ,
マルチサイクロンなど多筒式サイクロンの採用, 貯炭 運炭にブルトーザ，キャリォールスクレーパーの採用， 微粉炭機としてリングローラ型或はボールレース型の ごときバーチカルミル採用などもボイラ界の新動向と みられよう。

\section{工業黑炬之焚燒法の趨勢}

\section{I 鉄鋼関係}

本年度鉄鋼加熱炉用の燃料としてはやはり重油が優 勢である。特に近代式の三帯加熱炉，圯熱炉のごとき は専らこの燃料による。但し鉄鋼一貫作業をしている 製鉄所では，骸㟶瓦料および高炉瓦斯の余剩如何また は其の工場の熱管理上の独特の立場よりして瓦斯燃料 を種々に配分して使用している。たと光ば均熱炉に娟 炭瓦斯専焼, 或は混合瓦斯専焼 (100\% 高炉飞斯上り 100\% 䯓炭无斯まで変化し得られる), 或は重油専焼を 用いるごときである。また他の加熱炉についても同様 である。傾向としては混合瓦斯加熱（骸炭瓦斯十高炉 瓦斯）が今迄主として用いられてきたが，漸次髎湠瓦 斯専焼抢上で重油專，併用に進みつつある。これは平 炉に漸次荲油が用いられるに至り高炉瓦斯㧍よび䯓炭 瓦斯の余剩を生じたためと温度調節の発達したため熱 管理上有利となつたが故である。高炉瓦斯は主として 余剩をボイラーに用いるようになつた。

鉄鋼でも器械加工を主とする工場では，たと元ば， ベッジタイプの加熱炉, 焼鈍炉, 或は銀造炉のごとき 重油加熱に切換えられたものも著しく増加したが，依 然として今な抢石炭焚, 半瓦斯焚, 微粉炭焚, 発生炉瓦 斯焚のものもある。主として斯くの如きものは小規模 のものに多く中小工業に多い。新らしく新設されたも のは主として重油に切り換えられた。但し品質改善を 主とするもの,たとえば浸炭, 脱炭, 中性燒鈍炉の如き は電気或は瓦斯然焼である。またプログラムコントロ ールをなせる焼鈍炬すなわち昇熱時間，保熱時間，冷 却時間などを自動的にコントロールしたものは電気， 雷油瓦斯然焼である。鋳物工場焼鈍炉, 乾燥炉には微 粉炭然焼が多い。要するに, 機械工場或は仕上加工工 場に抢いては, 师内の雾囲気, 温度, 時間の調節の容 易なために漸次重油, 瓦斯 (主として骸炭瓦斯), 電力 （高周波を含む）進みつつあり,雾困気の調整として， 水素, アンモニア，プロパン瓦斯が用いられてきた。 鉄鋼熔解炬用の然料としては愹鉙炉およびキュポラ の如きは公知のと抢り骸炭であるが，その中愹鉿炉は 良質の米炭老用いることと鉱石の事前処理の適用抢よ 
び作業と設備の改善によつて炬の然料原単位は急速に 下降し，銑鉄屯当り0.6 位を示すごとき世界水準を抜 く成績を示した。次に転炉の燃料としては公知のごと く粼拉よび硅素, 並に宸素であるが, 近時スクラップ の割高と大手難のために螾銑を有する一貫工場ではこ の炉が急に着目されるようになり，新式の酸素上吹き 転炉を競つて計画する機運になつた。従つてこれに関 する外国のパテントが購入された。平炉の然料は従前 わが国において一貫工場は混合瓦斯, それ以外の工場 は発生炉瓦斯であつたが，近時ほとんど重油に転換せ られて行つた。けだし, 重油火焔の高温度と輝度とが 螾解能力を增加するとともに計量可能であり，自動調 節の設備を使用できるために炬の生命を延長し原単位 を低下して熱経済上甚だ有利なる故である。電気炬に おらいては補助然料として愹解時に重油を用いる傾向と なり電力使用量を節約している。ロール鋳造の愹解炉 は従前手焚傾斜型火格子燃焼であつたけれども近来微 粉㞸然燒に切り換えて良結果を示している。堝坩愹解 には主として骸炭を然料とし用いられて来なが近来更 油に転換され能力を增大しているが，堝畦の損傷も甚 だしくなる傾同にありこの点に改良が加えられつつあ る。

燃燒の補助として酸素を用いることは，数年前より わが国においても三三の製鋼所で試みられてきたが， その後精煉用として，また燃焼補助として各所て使用 されるようになり製鋼侍間を短縮し能力を増加方る良 結果を齊らしている。但し煙突よりの排煙が不愉快で あるので，市街地においては浄化の問題も起りつつ亦 る。また近来前述の酸素上吹き転师が各地て計画され つつあるのをみれば製鉄界における酸素の利用はます ます大となるであ万う。また圧延機の近代化による能 力堌大により，炉の負荷量が増大し炉の能力を增大文 るために急速加熱の研究が起つており，炬形が将来変 更されるべき機運にある。本年度において丸型炉が二 ，三の個所にて計画され実施された。丸炉は円形で炉 床が円形に運動するものであるから場所を要するけれ ぞも，連続加熱炉のごとく重量物をプッシアーにて押 し込む必要がなく，従って炉床の上に積み重ねるのみ でこれを移動させることを得る故に異形の各锺装入物 を同時に装入できるから便利である。

次に評器の活用について述へると，設備近代化と作 業合理化の線に従つてますますこの利用が旺盛となつ てきた。平炉の全自動化は一般に普及してきて特に下 期に鉄鋼増産の機運と共に平炬の再開, 新設によつて 整備されてきた。まず天井の温度を設定して重油の量
を自動調節し，これに関連して空気の量を自動調節す る。平炉の切換えは蓄蓺室の温度および加熱時間によ つて自動的に行う。炉内圧は自動的にダンバーを開橍 して行う。以上のごとき方式が多い。加熱炬は鋼塊の 温度によつて均熱带の油量および空気を調節し炬温に よつて加熱带の燃焼を，炉压によつてダンバーを調節 する方式である。均熱炉は炉蓋の開閉によつて自動的 にバーナの点隇, 空気の通大遮断苍行い, 炬温によつ て油量抢よび空気を調節する式である。枩風炉は切撸 え孛自動的に行い，燃焼瓦斯と空気との比率もまた自 動的に調節するとともに，熱風温度を一定に保つため に之もまた自動的に空気在これに混ずるなどの形式が 採用されてきた。以上自動調節化に必要な計器類以外 にも炉の作業上必要な各種の訫量が完棈せられて従前 よりも著しく合理性を増加した。特に本年度は鋼およ び銑の温度を直接に測定するために浸漬温度訫の発達 とその利用が盛んとなり，そのため鋼の品質の向_上並 に注入温度の適正化が得られた。炬の耐火材について 特に記すべきは断熱耐火徚瓦の利用であつてここれは 将来益々利用される徽候がある。その他不定形耐火物 の利用，需油燃燒用としての各種バーナの考案などが 現われた。

\section{II· 鉄鋼関係以外}

重油の使用制限のため最近重油への関心が薄らいだ ようにみえるが，弿炉に種油を使用することは本質的 に有理なことは明である。しかし今までその調査研究 が不十分なままに使用されてきたことは昨年度のこの 項におるても指摘した通りてあるが，学術振興会第 103 委員会 (熹炉および炬材の研究委員会)では 27 年 重油バーナ輻射バーナの研究分科会を作り，29年より 各工場の実態調查を始め, 使用重油の種類, 性質, 使 用時の加熱方法, バーナの型式その長所欠点, 蒠炉の. 種類, 大きさ, 被燒成物, 焼成温度範囲, 炉内温度分 布，熟効率，重油使用の優劣など詳細にわたる調査の 綪果が発表された。それによると，

a. セメント焼成回転签 各調查工場とも内部混気 式バーナを老用いている。これは微汾炭燃焼と同程度に 遅い燃燒速度の宿を作るためにこのバーナが用いられ ている。

b. 陶磁器焼成塞 単独案では大部分低圧噴霧が用 いられ，トンネル塞では低圧噴霧とべストハーロップ 型のものが同程度使用されている。

この理由としては，燃焼室が高温でさほどの長焰を 必要とせず，1次空気を多くして噴霧の悪い低圧空気 
噴霧型およびベストハーロップ型のものでも十分使用 でき，特にベストハーロップ型のものは最も哄霧が不 主であるがトンネル弿の然焼室温度は高温で一定であ るから，温度変化の大きい単独弿には使用されなくと もトンネル䇺には差吝えない。また耐火物焼成の場合 も大略陶磁器と同様といえよう。

c. ガラス蛒融蹇 蓄熱型槽黨はほとんぞ全部が内 部混気式バーナである。これはセメント焼成の場合と 同じく長焔を必要とするためであり，熱交換型槽案ま たは小型罢では低圧, 高圧, 内部混気が用いられてい るのは䇮炬の規模型式の相違によるものであろう。畦 佩塞では高圧噴霧式が最も多く油圧噴霧, 回転式がこ れに次いでいる。石炭焚より改造したものでは畦堝室 の構造と燃焼室と加熱室は離れているので当然バーナ は長焰を生じかつ噴雺の良好なものである必要がある ことから, 空気または蒸気の高圧噴霧式の採用が当然

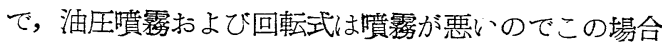
問題があるようである。

さらに重油燃焼によつて燃料費，人件費が節約され かつ調節が自由になり，品質の向上，今まで以上の高 温燒成が可能となつた反面，墨炉の寿命が短くなると か, 燃焼室煉瓦の愹損, 不適切な温度分布による局部 通熱なぞが問題となりこれらの問題は単にバーナの 性能のみならず, 燃焼室の構造, 1 次空気, 2 次空気 の導大方法すなわち空気の混合速度，焔よりの伝熱現 象などの綜合したものとして，これら問題の解決の必 要があると結論している。

最近塞炉構造の変遷の興味あるものはャメント焼成 筭であろう。この原因として各国のセメントの輸出が 盛んとなりその価格の切下げ, 品質の向上に対する要 求が苛酷になつてきたことが考元られるが，衆知のよ うに今までわが国のセメント回転塞は廃熱ボイラによ る熱回収によるものが大部分であつたが，燃料原単位 の切下げの要請からレポール塞, ロングキルンあるい はシャフトキルンなどの蹇が次第に設備されるように なつてきた。

レポールキルンではキルン出口のガス顕熱の $90 \%$ 近くが回収でき煙突へ逃げる排ガス温度は $100^{\circ} \mathrm{C}$ 以 下になり，今までの回転弿でクリンカー $t$ 当り所要熱 量が乾式では 170 万kcal, 湿式では 200万kcal である に対し，110〜120万kcalに低減できる。わが国でも現 在 6 基稼動している。また最近湿式で長さ130〜165m のロングキルンが用いられ始め現在わが国でもすでに 6 基が稼動している。この熹は墨尻近くに設けられた 特殊な装置て熱交換を行い廃ガスの顕熱を回収してい
る。従つて弿炬より排出される廃がス温度も $180^{\circ} \mathrm{C}$ 以 下になり熱効率よく所要熱量はクリンカー $\mathrm{t}$ 当り 150 万kcal 以下にすることが可能である。

またクリンカー冷却機は従来ほとんと大部分が横型 円筒型のロータリークーラが用いられていた。その外 篤の下端部を気密に围いその中にグレートを設けたグ レートクーラがある。これによればロータリー・クー ラに比し熱回収はよくクリンカーは $200^{\circ} \mathrm{C}$ 以下に冷 却される。最近はこのグレート・クーラを改良したェ アー・クエンチングクーラが多く採用され始めた。

従来のクーラーも潮次エアー・クエンチングクーラ 一に取り替えられつつある。これにより 2 次空気の予 熱温度も $800^{\circ} \mathrm{C}$ 程度までにすることができる。

シャフトキルンの特徵は燃料消費量の少ないことに あるが,謇の操作上の欠点, センント品質の不安定など のために今まで余り用いられなかつた。これは原料を ペレットにして送入していたことによるが，最近は燃 料と原料とを密に混合して粒径 5〜20 mm 程度の一定 のものに成粒したものを用いるようになつた。これに よりクリンカは内部まで均一に焼かれるようになり， 燃焼用空気も風圧を大きくし風量も増大し焼点温度も 上昇し，かつ焼点部も上方に移行し燒成帯も薄く急速 焼成とクリンカの急速冷却ができる。これはまた空気 の予熱温度を高め, 焼点温度を高めることになる。以上 の改良によつてセメントの品質も従来の回転䈇による ものとの差異もなくなり各国においても採用され，わ が国に括いても最近採用された。しかしシャフトキル ンの燃料としてはコークスあるいは揮発分の少ない石 岸, 例えば無煙炭などを使用しなければならないこと は大きな欠点で,使用範囲も制限されることになろう。

\section{燃燒に関する研究}

昭和 30 年度における燃焼に関する研究についての 国祭的な事業として Fifth Symposium (International) (on Combustion'1) の刊行々，英国および米国 の機械学会の燃焼に関する合同会議”の開催とがあ る。前者は隔年に行われる燃焼シンポジウム（第 5 回 は 1954 年に行われた）の報交を集録したもので，前 回までのもの之同じく多数 (90 篇) の最新の燃焼の研 究に関する報交と, 蜘焼を応用した工学上の諸問題並 に燃焼の基礎研究に関してその方面の権威者による総 説 (11篇) がおさめられている。報文の種類!は(1)燃 料滴の燃焼 ( 2 )固体の燃焼 ( 3 ) ロケット推進然料の然 焼(4)拡散炎と宸素の生成(5)エンジン内の燃焼(6) 
特殊実験技術 (7)燃燒反忘の運動学 ( 8 )火炎スペクト ルと分解エネルギの各項目にわかれ，現在の燃焼研究 の主要な傾向を知ることができる。

後者は 5 月に米国, 10 月に英国に抢いて行われた もので(1)一般燃燒研究 (2) ボイ 内燃機関 $(5)$ ガスタービンの 5 部にわかれこれら設備 における燃焼に関する問題, 並にその研究の最近の動 向について総説的にのべられた数十篇の報交からなつ ている。

然焼に関する研究は非常に困難なもので従来目標の 不完全なものがしばしばありまた同種の研究が各所 で別個に行われるという非能率な点が多かつたが，こ れら国際的の交流によつて多数のすぐれた研究が促進 され，同時に燃焼という多岐に亘りかつ複雑な現象を 解明するのに最も能率のよい組織立つた方法が見出さ れることが期待される。

燃焼の基礎的な研究については然焼シンポジウムに 数多く出ているがその他に燃焼の機構に関しては K. G. Willlams, J. E. Johnson \& H. W. Carhart 氏 ${ }^{3)}$ は冷炎の温度とガス成分の測定を行つてその生起機構 を論じ，J. H. Burgoyne \& H. Hirsch 上(4)は $1000^{\circ} \mathrm{C}$ 附近に抢いてメタンを渦室内で行わせガス分析より反 忘連鎖担体と燃焼機構を論じている。J.Weinberg氏 は賦活エネルギと撚焼機構の関係を論じ, Y.M.Mias, T. W. Price \& J. H. Potter 氐6) は球形ボンブ中の 火炎伝播の間の温度变化をナトり它 $\mathrm{D}$ 線法によつて 測定して理論式との関係を求めている。

火炎伝播についてはG.N.Badami \& A.Egerton氏i) が平炎法により，A. Egerton \& A. H. Lefebvre氏 が管内の火炎伝播をシュリーレン写真で測定すること により, 各種単体がス, 混合ガスの火炎伝播の速度に ついて精しい結果を得た。

都市ガスなどの燃燒性を研究するために J.Grumer， M. E. Harris \& H. Schalz氏9) は各種単体がス, 混合 ガスの逆火と吹消えの限界を測定し，P. F. Kurz氏10) も同様に炭化水素系の各種混合がスの吹消立を研究し てガス相互の燃焼促進作用や抑制作用があまりないこ とを見出している。

シェェッ燃焼器の空間蓺発生率の限界として化学反 応速度に必要な最小限の空間容積があるがこれを研究 するため J. P. Longwell \& M. A. Weiss 氏(11) は球 形の耐火材燃焼室の中心から然料空気混合気を念速に 吹出して撚焼させ燃焼ガスの分析を行つて反応速度を 求めた。

炭化水素然料の燃焼で炭素(煤)存生成することはガ
スタービン燃焼器, エンジン内などで大きな問題とな つているがこれに関して J. C. Street\& A. Thomas 氏12)は混合気炎の状態て然焼する場合の炭素生成の 実験を行い, 燃料の性質之孷素生成の関係を求め, 炭素 生成の機構を論じている。またェンジン内て附着炭素 が過早着火の原因となることと関連して G. J. Nebel \& P. C. Cramer 氏 ${ }^{13)}$ は炭素之鉛化合物との混合物の 着火温度を測定し鉊の触媒作用とその抑制剂について のベている。

固体燃料の燃焼は現象がさらに複雑なため基礎研究 は比較的少く Bimalendn Ghosh \& A. A. Orming 氐 14)は特殊な装置で均一に混合した微粉炭混合気在高 温の電気师内に吹込み輻射熱によつて着火するのに要 する時間を求め炉温, 石岑の性質, 空気中酸素濃度な ぞとこの着火の時間との関係を求めている。また L. Cohen \& N. W. Luft E-15) は微粉状の可然物質存層 にして平板上に置きこの一端から着火してこれがも 元移つて行く性質に関して研究している。

\section{交献}

1) "Fifth Symposizm (International) on Combustion" The Combustion Institute. (Remhold Publishing Corporation, N. Y.) (1955).

2) "Joint Conference on Combustion" The Institution Mechanical Engineers and The American Society of Mechanical Engineers.

3) Williams, K. G., Johnson, J. E., \& Carhart, H. W., Ind. Eng. Ohem., 47, 2528 (1955).

4) Burgone, J. H. \& Hirsch, H., Proc. Roy. Soc. A, 227, No. 1168, 73 (1954).

5) Weinberg, J., Proc. Roy. Soc. A., 228, No. 1182, 331, (1955).

6) Miao, Y. M., Price, T. W. \& Potter, J. H., Traus. A. S. M. E. 77, 89 (1955).

7) Badami, G. N., Egerton, A., Proc. Roy. Soc. A., 228, No. 1174, 297 (1955).

8) Egerton, A., \& Lefebvre, A. H., Proc. Roy: Soc. A., 222, No. 1149,206 (1954).

9) Grumer, J., Harris, M. E. \& Schulty, H., I. E. C. 47, 1760 (1955).

10) Kurz, P. F., F uel, 34, 269 (1.955).

11) Longwell, J. P., \& Weiss, M. A., Ind. Eng. Ohem., 47, 1634 (1955).

12) Street. J. R., \& Thomas, A., Fruel, 34, 4 (1955).

13) Nebel, G. J., \& Cramer, P. C., Ind. Eng. Chem., 47,2394 (1955).

14) Bimalendu Ghosh \& Orning, A. A., I. E. C., 47, 117 (1955).

15) Cohen, L. \& Luft, N. W., Fuel, 34, No.2,154 (1955). 


\section{選炭エ業の䞨勢}

1. 概 況

宸況は前年に引続き買手市場を続けたが，前年末か らの大手各社の自衛上の出炭抑制が漸く軌道に乘り貯 崖む前年を下廻り崖況は淞安定した。下期に大るとと もに輸出の好調から需要もいくらか上昇に転じ漸く愁 届孝開くに至つた。

従つて選宸界においては新設増設工事は少なかつた が前年に引続き各種の合理化工事並に品位向上，炭質 改善その他の対策工事が活発に行われた。

合理化工事としては選炭工場の集約（日窒鉱業汇里 硫虎江迎砄に集約), 系統の単純化，選炭機の一台当り 処理能力の増大化(志免, 雄別), ブラッドフォードブ レーカー採用(山野, 嘉穂)による人員の節減その他反 撥式クラッシャ一, 振動篩機の堌加などがみられた。

品位向上，炭質改善の対策としては精炭の再選（嘉 穗, 高松, 矢岳, 鹿町), 二号炭の再選 (美唄堅坑, 神 威, 油谷芦別, 下芦別)による品位向上または炭層別 に時間を区切つて行う層別選炭 (上山田, 歌志内) が 行われるようになつた。微粉炭の浮游選炭もますます 増加した。孷質を調整して需要者の要求に応えるため には採掘炭層を撰択することの他に混炭が考えられ る。三池崖と高松二号宸との混宸はこの点注目に何す る。低品位炭の多い宇部地区における選宸強化は著し く特に需要の活発な無㖶宸地区での品位问上は目ざま しい。

低品位宸の活用による石崖吰業の合理化は近時大き く唱導されてきており今年は崎戸，三池，登別に抢け る製塩工場が建設途上にあり，また常盤地区での低品 位炭による共同火力発電が本決りとなり，或はまた太 平洋宸砸での沈澱微粉宸の流動式低温乾溜炉がスタ一 トするなど漸く各種の新規事業が緒についた。その他 小名浜の日本水素はコッパース炬による低品位微粉崖 の完全ガス化污操業定開始し，二瀬，鮯田，築別，太 平洋など自家発電所の合理化工事として低品位炭の利 用が実現した。最近完成した新鋭火力発電所はいずれ も5,200カロリー位のものを目標に設訐されて抢り， 煖房用炭におおても最近北海道では新型ストーブの登 場により従来の上級中塊崖より下級粉炭に移行しつつ あり，国鉄電化による上級国鉄用炭の減退傾向ととも にこれら一般然焼用宸は上級宸から漸次中下級粉炭に 移りつつあり注目を要方る。一方原料炭は外国炭の高 騰から内地炭に移りますます高品位炭を要求されてき ている。
2. 選孷方式

分離精度の向上， 1 台当りの好理能力の増大を計る ために樋流し式およびピストンジグからバウムへの転 換が多くみられた。常盤地区の向洋炭砿新選宸工場は 主洗中塊バウムと粉㞸レオラバールとの組合せにより

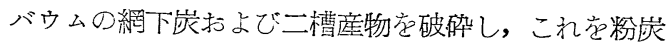
ととさにレオラバールにて処理し，バウムから中塊と 洗粉をレオから洗粉と並粉とを産出寸る方式を採用し た。また同地区の櫛形孷砄でに主洗にバウムを，再洗 に電液選炭を計画して抢り，湯本六坑では内郷吰に引! 続き火力発電用炭としての低品位炭回収用に硬の再選 用フンボルト型雷液選㟶孛計画中である。大島炭矿で はバウムへの自動給孷方式を新に採用し第一槽の硬心゙ ッドの厚さと第二槽の空気調節弁とを連動されるよう にし，また別に同砬では回転数を多くし衝程を短くし た細粉炭用特殊ジグを計画中である。日鉄鉝業ではバ ウム改造による細粉炭用人工ベッド方式を採用した。 また万字，油谷ではテーブル選崖を閉始するなど新ら しい選炭方式の組合せと衯孷選炭に関する新らしい試 みが行われてきている。重液選孷は大した発展はなか つたが常盤地区では低品位炭回収用として引続き増加 しつつあるし，新らしく取り大れたものとしては下芦 別における再選用のもの並に高松炭硫では中塊精選の ためにハーデンジ型分離機による銅銹をメジウムとし た設備が設けられた。

\section{3. 微粉炭の処理}

微粉炭の回収，品位向上については引続き工事が行 われた。古賀山矿では回転篩による上微粉の回収, 大 の浦では 2,000 粍径と 500 粍, 250 粍径の低圧サイク ロンを 3 段に使用する微粉品位の向上を実施した。そ の他古河目尾のサイクロン，崎戸ドルシックナー，江 迎サイクロン,シックナー, 埴生ドルシックナー,三井 芦別オリバーフィルター，万字浮選開始など処々て増 設改良が行われた。湿式サイクロンは東大今泉氏の調 査研究が選炭大会でも発表され種々の用途, 型式が紹 介され，また漸次低圧操業の方向に移りつつあり需液 選炭への発展その他広範囲えの利用が期待される。脱 水，乾燥については引続きインペリアルフィルター， 遠心脱水機が検討されつつあり，また別に細粉用脱水 振動篩面上に浮選フロスを供給して脱水する方法も芦 別その他で簡単に行われている。乾燥については流動 式方法がいくつか実施に移されており，漸次成漬が判 明されつつある。これらの脱水乾燥法が確立されるに つれて微粉炭のガス化その他化学工業への利用が拓か れてくるものと期待される。 


\section{4. その他}

第 5 回全国選崖大会は10月初東京で開催された。山 口吉郎大会長の本邦選炭の䞶㳹老初資源技術試験所 の研究発表その他貴重な研究発表が行われた。検討議 題としては選炭機器の磨耗抢よびその管理並に石炭の 粉化についてが採り上げられ, 殊に後者は山元から種 々の翰送径路を経て工場に至るまでの粉化状況を明ら かにしたもので，今まで明らかにされていなかつたこ の方面の突態が明らかになつた。また資源技術試餄所 馬場氏司会の石炭の利用加工についても種々発表が開 陳された。

\section{選炭に関する研究}

昭和 30 年度における選炭関係の研究を文献によつ て紹介する。

a. 重液選炭, 各国にて重液選炭の操業については 安定性を増し，設備も多くなりつつあるが，研究にう いては基本的な細部問題, すなわち冓液の粘度, 污濁 に関するものが多い。特にかかる懸濁液の粘度測定は 却々困難であり, 昭和 31 年度の全国選孷大会はこれ に関する検尌会を行う予定と聞いている。

まず和田氏ら は数種の懸濁材について, 粒度, 懸 溜重液の濃度などの変化による粘度を測定し, 粘度に 関する新なな実験式を提示している。角田氏2)は実操 業における冓液の污染の状態, 並びにその原因に関す る諸調査, 研究の結果を報告している。新しい電液材 に関するものとして松尾氏3)のシャモットによる実験 報告, 斎藤氏やの硬より回収されるパイライトによる 操業報告がある。西川氏5) は砂鉄を重液材として新形 式のサイクロン型重選機による中塊処理を報告してい る。武内氏(6)は従来困難視されていた粉孷处理につい てフンボルト型重選機による 8 1.2 $\mathrm{mm}$ 炭の選別に ついて報告している。国外に打いては C. W. H. Holmes 氏7)の重選操業における重要諸因子について の考察がある。

b. ジグ選炭 定性的なことより定量的検钨に大り つつ西り，特に選別に関係する因子の非常に多いジグ 選崖においてはこれらの因子を測定計器により定量的 に測定し，それらの綜合的関連を究明せんとする傾问 にある。細粉ジグも漸く国内にも考慮されてきた。

横沢氏\$) はジグにおける比重別成層の原理解明に当 つては槽内水平流の影響を無視しえないことを実験的 に報告している。秦氏ら9ねオシログラフにより波形， 空気圧力の変化，さらに被選別粒子の運動などに関し
て，これら基檚的事項を定量的に測定することにより 複雑なジグ・ストロークの解明を鹆みた。また北海道

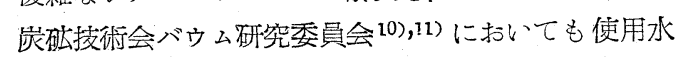
量と選別成績の関係，打よび風圧と波高の基礎因子に つき定量的測定を実施し, その調查, 試験結果を報告 している。

高桑氏ら12》は床網の下に空気室を納めることにより 選別室の波動を均整ならしめ, かつ穖械の大きさ究縮 少けしめうる新形式の気動ジグを発表している。酒井 氏年引は本邦初めてのベッド・ジグについて報告してい る。ベッドには長石あるいは人造石を使用している。 その他心゙ッド・ジグについては G. A. Vissac 氏14)の ものがあり, 理論的䠸察它行つている。中田氏ら ${ }^{15)} は$ バウム式とレオ式水選機について原炭の可選性および 産物品位により比較検討している。長谷氏16)は二蔶つ ロートによる精炭灰分の安定について報告している。 水選機の自動調節については秦氏ら ${ }^{17}$ の自動給炭装置 についての報告がある。

c. 浮遊選㟶, 中川氏18》は三井芦唄におけ浮選剂 T. F. C. No. 1 とクレゾール油との比較抢よび浮選温度 の影響について，岡部氏 ${ }^{-19}$ ) は大島における $\mathrm{FW}$ 型と SW 型浮選機の比較について 報告している。微粉岸 の浮遊性に関するものとして P. Moiset 氏20》のケロ シンパイン油およびクレン゙ール酸の混合油拈よび 表面活性剤 Tensatil DA 120 による研究がある。 J. Mainhood 氏ら 21 はテトラリンで條件賦与した低 品位崖の起泡偊として各種一価アルコール，一価の酸 它含む約 120 種類の極性有機化合物に関する系統的研 究を行つた。って他泡洙浮選機に関する試験として D. Simpson 氏22)の報告， R. B. Booth 氏(23)の浮選: 全般にわたる考察, 瀬戸氏24の本邦における起泡鼡と 捕収剂についての解説がある。

d. 微粉および細粉処理 テーブルに関しては児玉 氏5)の理論的考察, 丹羽氏96)の古賀山吰における操業: 報告がある。コンバートル法に関しては佐々木氏27)の 研究がある。

脱水に関するものとして K. Lemke 氏28)の脱水の 方法と目的についての考察, J. W. Phillips 氏ら 29 ? の理論的研究，G. Gräf 氏30)の層状傾斜ポケットに

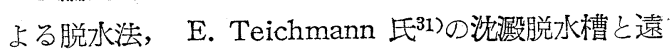
心脱水機を組合せた脱水法，C. E. Silverblatt 氏ら 32)のディスク・フィルタによる脱水，林氏ら ${ }^{33)}$ の遠心 脱水機による浮選精孷の脱水報告などがある。 その他松野氏 ${ }^{34)}$ は選孷水処理に抢ける微粉の分離, 浄化濃縮について考察を行つている。F. J. Fontein 
氏ら ${ }^{35)}$ はサイクロン選炭設備の最も新しい簡易化につ いて報告している。同しく F. J. Fontein 氏36)はオラ ンダ国営孷吰に扎いて $0.5 \mathrm{~mm}$ て湿式フルイ分けする 場合に使用される新しい弧状フルイについて報告して いる。児玉氏3i゙はサイクロン，シックナおよで沈洪池 について理論的考察を行つている。

e. 管理 荻原氏 ${ }^{38}$ は管理困の特性を一籄の数值で 表現するため信用係数その他の倸数について検討して いる。北氏39)はサンプリング基準, 試験などについて 詳述している。

選炭成績の評価に関しては児玉出40)は選宸機性能の 新表示法としてトロンプ曲線に代る $\mathrm{K}(\rho)$ 曲線を提 案けた。O. Sommer 氏411は工業的分離がぞの程度の 完全さで行われているかを示す数值が長さまたは面積 の比から導かれるグラフ的な方法を採用した。 R. M. Horsley 氐ら 42 引は従来の諸種の成績表示法について考 察を行つている。

f. その他 石炭の枌化防止について山田氏43)!は粉 化の害体について数理的検討を行つた。H. Bannister 氏ら 4 (4)水を満した浅いプールに落下させることによ る塊崖の粉化減少を報告している。佐々木氏45う電熱 フルイによる湿鬥試料のフルイ分けについて報告して 泀。R. Cheradame 氏46) は選崖工場の型式老決定 する際に考慮す心゙き事項を技術的に検討している。

その他利用関係について一, 二紹介すると, 広田氏

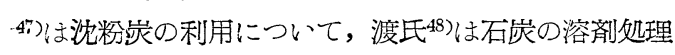
と煉炭化について報告している。

以上昭和 30 年度の選炭に関する研究を文献により 紹介にたが，大体において研究も基本的細部問題の究 明に向けられ，今後は細粉粒度以下の選別，これに附 随方る脱水の研究は益々重要となろう。

\section{文献}

1) 和田正美, 平野仁士, 本閪寅二郎, 日鉣, 87, 802, 173.

2）角田貞治，九技， 8，76，40 和よび $81 ， 247$.

3）松尾敏美，九技， 8，86，436.

4) 斉藤吉彥, 選炭, No. $20,1377$.

5) 西川豊, 選炭, No. 20, 1416.

6) 堀內武, 日鉣, 71, 807, 491.

7) C. W. H. Holmes, Coll. Eng., Sept., 368 (1955).

8）横沢些八，炭技， 10, 4, 102.

9）秦正直，選炭，No. 20, 1353. 秦正直, 三宅龍夫，日鈆，81，807，459.

10) バウム研究委員会, 炭技, $10,8,242$.

11) " $10,9,267$.

12）高桑健, 松村守夫, 日鉣, $71,800,63$.
13）酒井㨁, 日鉱, $71,807,467$.

14) G. A. Vissac, Min. Eng., Jully, 649 (1955).

15）中田行雄，中山政男，日鈗，71，807, 473.

16）長谷義雄，三菱炭坑技術，4，3，103.

17）秦正直，三宅竜夫，日鉣，71，807，459.

18）中川孝一, 日鉱, $71,807,507$.

19）岡部治七, 選炭, No. $20,1310$.

20) P. Moiset, Publs. assoc. ing. faculié polytech. Mons No. 1, 1 (1955).

21) J. Mainhood and P. F. Whelan, J. Appl. Ohem. Mar., 133 (1955).

22) D. Simpson and P. F. Whelan, Fieel, Apr., 89 (1955).

23) R. B. Booth, Ind. Eng. Chem., Mar. 47, 551, (1955).

24）瀨戶英太郎，日鉣，71，807，891.

25）览玉八郎, 石炭評論, 6, 1, 32 .

26) 丹犲雄之助, 九鉣, 23,3 .

27）佐々木信郎, 炭研, 6, 12 .

28) K. Lemke, Glückauf, 17/18, 452 (1955).

29) J. W. Phillips \& D. G. A. Thomas, Coll. Eng., Jan. 15 (1955).

30) G. Gräf, Glückduf, 1/2, 40 (1955).

31) E. Teichmann, Glückarif, 29/30, 829 (1955).

32) C. E. Silverblatt, \& D. A. Dahlstrom, Ooal Age, Jan. 76 (1955).

33）林善芳, 斉藤善男, 日鉣, $71,807,547$.

34）松野栄治，日鈗， 71，807，539.

35) F. J. Fontein \& C. Krijgsman, Glückauf, 29/30, 823 (1955).

36) F. J. Fontein, Glückauf, 27/28, 781 (1955).

37）览玉八郎，石炭評諭，6，3，150；4，235；6, 369.

38）萩原良明，炭技，10，2，41.

39）北修一，炭技， 10, 7, 203.

40）児玉八郎，石炭評論，6,10, 587.

41) O. Sommer, Glückauf, 31/32, 878 (1955).

42) R. M. Horsley and P. F. Whelan, Canad. Min. Metall. Bull., Feb. 74 (1955).

43）山田晴俊, 炭技, 10, 1, 8.

44) H. Bannister and P. F. Whelan, Coll. Eng, Mar., 117.

45）佐々木信郎, 炭研, 6, 7, 203.

46) R. Cheradame, Coll. Eng., Nov. 462. (1954).

47) 広田和一，炭技， 10, 7, 199.

48）渡眞次郎，炭技，10,12, 365 .

\section{熱管理運動の趨勢}

昨年度蓺管理における大きい動きは，エネルギ総合 対策抢よび生産性问上対策に沿つた一連の流れで，石 炭合理化法に基く低品位炭燃焼，重油ボイラ設置制限 法あるいは，作業の標準化をるらつた業種別熱管理標 準方式の調查研究などの例があり, 都市におっりる煤煙 
防止の問題もエがキ対策に関連して主として環境衛 生の見地から大いに取りあげられた。また原子燃料や 太陽熱の利用の問題は昨年度エネルギ界におけ方真大 事項であるが，これまた熱管理に大いに影響をきたし つつある。すなわち新石炭化学, 石油化学の急速な発 展から，従来熱源であつた燃料が次第に原料化する傾 向にあり，しかも今後ェネル命需要の増加は，ここ数 年で石炭に換算して 1 億 $\mathrm{t}$ 以上を見込まれ，生産不足 を新らしいェネルギ原に求めなければならないという わけであろう。しかし，これ克直ちに今日の工業生産 に期待するということは不能であつて，当面の問題と して, ぞうしても使用効果の增加, 熱管理の強化が必 要なわけである。こうした主張は英国でもまた行われ ている。

中央熱管理協議会の熱管理技術委員会においては， 生産性向上対策中の重要な要素である標準化に関係し て，金属加熱炉，セメント工業におりる標準目標をた て，ボイラなぞの熱精方式を学決定し，これが普及につ とめた。こうした作業の標集化, 或は然料原単位の決 定には，推計学が椨用され，ようやく管理技術として の新らしい体制が確立されてきた。11月広島市および 宇部市において開催された第 8 回全国熱管理大会は， 講演，見学などは例年のとおりであつたが，特に燃料
会場を設け，一部に全国蓺管理メーカの展示と一部に 一般人の熱管理の啓蒙運動として「燃料のしおり」を 配布して然料常識の普及につとめた。昨年度の熱管理 強調期間は「排熱回収」の徹底と「ボイラ熱精算方 式」の普通に露点がおかれたが，中央熱管理協議会で は，排熱回収の特集号を編集し，熱回収の理論と場に おける実例在発表した。

8月 10 日「重油ボイラの設置の制限などに関する 臨時措置に関する法律」が出され，引続き 10 月には 施行令と施行規則が出ている。このボイラに抢ける重 油使用の制限が，エネルギ総合対策「重油と石炭との 消費分野を明確にし，石炭使用学適当と方名用途に打 ける重油の消費を抑制する」の一環として，まず取上 げられたのは，石崖えの転換性が考元られたわけで， 重油の使用量年間 $120 \mathrm{kl}$ 以上設備がその対象となうて いる。

工業拔術院の発表による之, 熱管理指定工場 $(1,30$ 0)の実態調查に扎て燃料使用設備の熱効率は, 鉄 鋼業の連続加熱のように $45.3 \%$ (28 年1月～12月本 均）から最近 50〜60\% に近ずきつあるものや或は 新鋭火力発電所の発電效率 $5,500 \mathrm{kcal} / \mathrm{kg}$ で $37 \%$ 亡 いうような設計もあるが，一般の熱効率は低く第 20 , 21 表のような数字が出ている。

\section{第 20 表 ボイラの熱効率}

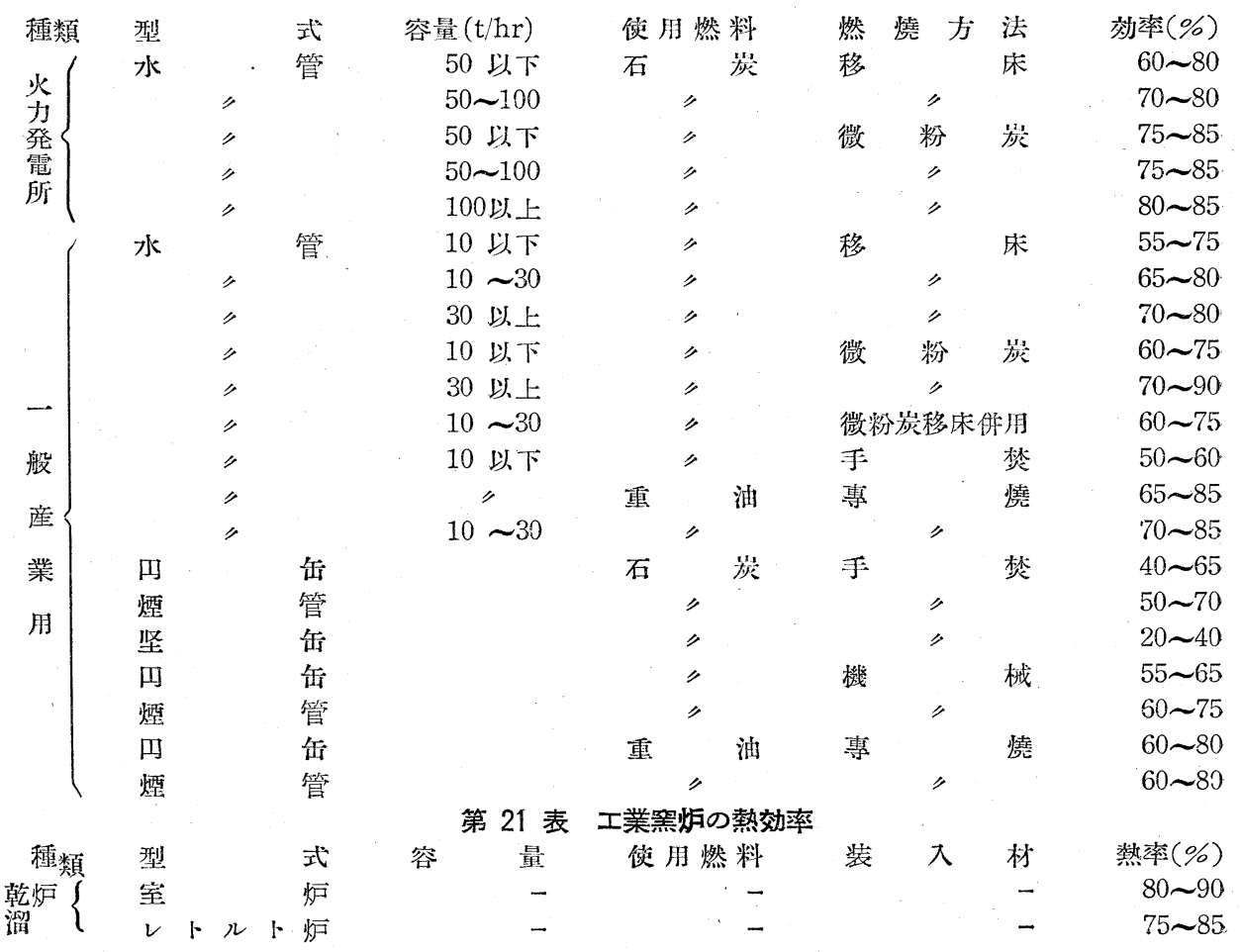




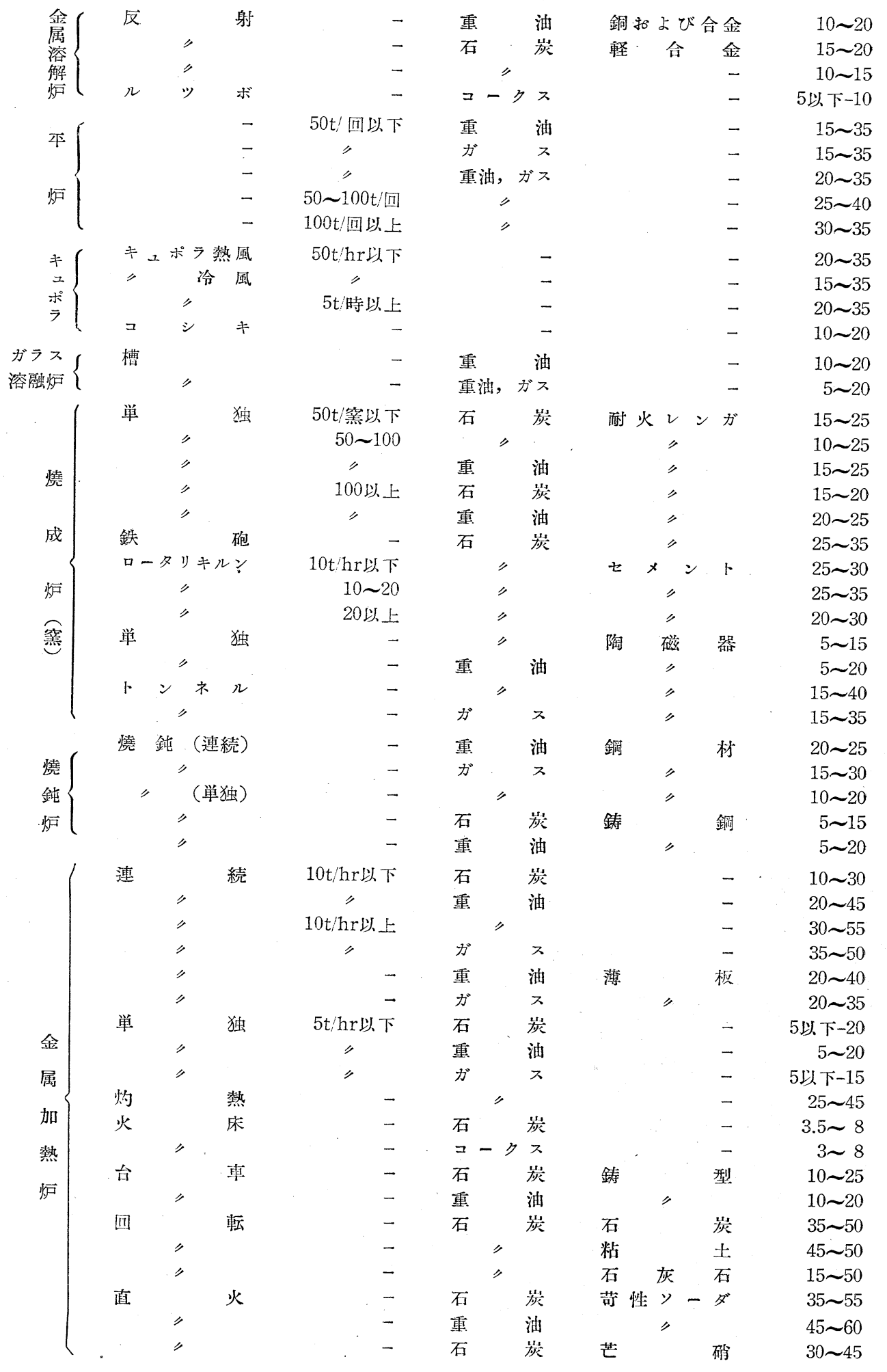

(工業技術院調整部筫料) 
熱管理士の数は，昨年度は国家試験，研修終了を含 めて 500 名堌と年々増加し，新らしい外国技術も導大 （甲種契約支払は，29 年約 47 億口，乙種支払契約 25 〜29 年 42.5 億田) されォートメション, 自動制御の 傾向が䈐しく強くなつたが，その他技術の面では，低 品位炭燃焼，輻射型水管ボイラ，搔込ストーカ，加熱 炉の改造，酸素計，イォン交換樹脂方面に目立つたも のがあり,さらに今後適正ェネルギ源の適正配分設備 の近代化, 国産設備の育成や基礎研究の実施などに重 点が向いつつあり，研究組合的な行き方について大い に考えられてきた。

なお昨年 10 月米国アリゾナ西南地方て第一回万国 太陽エネルギ利用会議が開催され 30 国, 700 人の関 係者が出席し，日本からも代表が出て研究を発表した ことなどは，熱管理の面からもまた大いに関心を有す べき問題である。

\section{熱管理に関する研究}

終戦後 10 年間の熱管理技術の向上はめざましいも のがあり，30 年度においても熱設㣁の近代化は著し く、これに伴う蓺管理の研究も高度のものとなつた。 しかし，これらのことは一般に大企業についていわれ ることであつて，中小企業に扑てて，熱管理思想は ある程度普及されたとはいうものの，旧態依然たると ころが多い。これは国内のみでなく，外国でも同様の ことらしく, ドイッに抢ける商工業地区の, 主として 中小工場の熱管理䛦断 ${ }^{1)}$ によると然料消費量 $20 \mathrm{t} /$ 月 以上の 12 工場については平均 $27.5 \%$ の燃料の節約 が可能であり，そのうち $7.3 \%$ はほとんど設備費を要 しないものである。主な熱の損失はボイラで生じ，こ こて燃料の 13〜39\% の節約が可能でありまた燃料 消費量 $20 t$ /月 以下の 40 工場について診断したところ ここでも同様に，平均 15\% の然料の節約が可能であ ると報告している。

わが国では低品位炭の産出が多いため, 低品位炭の 有効燃焼の研究が今年度においても多くなされた。資 源技術試験所》にに抢いては，基礎実験の結果により,ラ ンカシャボイラの炭出しロに直結する小型送風機を試 作し, 約 $3,500 \mathrm{kcal} / \mathrm{kg}$ の低品位炭を $200 \mathrm{~kg} / \mathrm{m}^{2} \mathrm{~h}$ 以上 の高燃燒率で有効に燃焼することができた。また，日

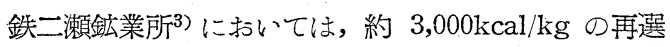
硬炭をマルチン式ストーカによつて燃焼し，ほほ満足 な結果をえている。National Coal Boad が炭坑に打
いて行つた実験けにおおても，6,000〜8,000BTU/1bの 低品位炭をマルチンストーカを用いて有効な燃焼がで き，かつ負荷の変動にもよく応しうるという結果省え ている。火力発電所の低品位炭利用の例としては，宇 部炭 $(3,600 \mathrm{kcal} / \mathrm{kg})$ の専焼, 無煙炭 $(4,400 \mathrm{kcal} / \mathrm{kg})$ と宇部炭との混焼などについての報告5)があり，石炭 の粉砕性, 重油の混燒, 然焼装置, 灰処理などに問題 はあるが，かなりの実績をあげている。

炭坑においては然料の有効利用としては上にあけた 上うな低品位炭の自家消費があるが，坑内保安上廃寨 している坑内がスを熱源として用いることが研究され ている。炭坑の深度はますます梁くなり，これに伴つ て坑内ガスの発生量も多〈なつているのでこれの積極 的な利用に関心が抵われ，北海道炭鉱6)ては暖房用浴 場用，ボイラ用などの熱源のみならず，カーボンブラ ックの原料にまで利用されるに至り，今後の研究によ り,さらに広い範囲の化学工業の原料となしうること が期待される。

燃焼以外の, 低品位炭利用の方法としては宗像氏ら 7)のスラグ・セメントの研究がある。すなわち、スラ グタップボイラで生ずるスラグに石ニウ，ポートラン ドセメント・クリンカなどを混ぜて，強度などがか゚ー トランドセメントに劣らないスラグ・セメントの実験 的製造に成功した。

ボイラの熱管理的な研究としては, B.C.U.R.A. で 行つた詳細な研究8がある。これは，チェングレート・ ストーカだきのエコノミック・ボイラを用いて行つた 約 450 回の実験結果をとりまとめたもので, 炭質, 粒 度, 湿分, 兏分, 過剩空気, 熱負荷, 2 次空気量など がボイラ効率に与える影響を研究したものである。こ れによると，使用ボイラについては，乾排が ス損失 $L g$ は次式で表わされる。 $L g=7.11+0.073 E+0.047 \mathrm{H}$ $+0.0004 E H$ ただし $H:$ 大熱 $E:$ 過剩空気

また，一般的に次のような結果をえた。(1)グレー 卜の空気ダン 1.0 の位置はボイラ効率に殆んど影響奇 与えない。(2)火層厚さは可分の多い石炭, 乞のなか でも特に片の融点の低いものの場合には大きな影響を 与える。(3)火層上への 2 次空気は燃焼に特に効果的 であるということはない。(4)粉炭に含まれる湿分は 燃焼に大きな関㥒があり，石孷の粒度が小になれはなな る程, 適当な湿分量は大になる。(5) I $/ 2$ " 〜 以上に 広い範囲の粒度の粘結性の石炭はチェングレートには 適しない。(6)灰分の増加とホイラ効率の低下割合は ほほ直線的な関係にある。

また A. E. Morolin9) は炉筒にジャマ板をつけて, 
伝熱を促進して良結果をえた。このジャマ板は下部に 手持棒のついた半円形のものでこれを炉筒上部に沿 つて設けた。燃燒は良好となり，かつ炉筒底部のガス 速度が大になるから，灰の沈積が少なく，最低 $4 \%$ の 然料の節約ができた。この他，手だきランカシャボイ ラ，下込めおよび重油だきセクショナルボイラについ て, Fuel Research Statian が行つた実験 ${ }^{10) か ゙ あ る 。 ~}$ これは煤㖶を防止し，ボイラ效率を向上させるために 火層上への 2 次空気の導大方泆抢よで装置について研 究したものであつて，手だきボイラでは特殊のたき口 屝をつけて,ここから火層上に入る 2 次空気量を調節 することによつて燃焼を完全にし，良結果をえた。ま た油だきのときには着火アーチを設けて不完全燃焼を 少なくすることができた。

ボイラの外部伝熱面のデポジットおよび侵ショクに ついてはイギリスで多くの研究がなされた。エャセ一 タの腐ショクおよびデポジットによる閉塞を防ぐ方法 としては, 蹨料の選択, 然焼方法の改善などがあるが Lees 氏11は土ヤヒータとれ自体に多少の改善を加え てよい結果をえた。エャと一タの侵ショク，および閉 塞は主として空気の大口およびこれに沿うェャせータ の底部に生ずる。これは土ャヒータに入る空気の分布 が不均一であるからで, 空気入口前に適当なジャマ板 を設け，流入する空気の分布を均一にすることによつ て防ぐことができ，またェャヒータの途中から，一部 の空気を大れるようにするのもよいし，空気の流れを 熱ガスと平行流にするのも有効であつた。

Crumeley氐ら ${ }^{12)}$ はストーカだきと微粉炭だきボイ ラの高温伝熱面デポジットの特性を研究した。微粉炭 だきボイラでは Ca 塩がデポジット成長の媒体となる ことが多く，両者のボイラではデポジット量は石炭中 の $\mathrm{Cl}$ 量によるようであるが，微粉炭だきでは $\mathrm{S} も$ 重 要であるとしている。Easton 氏13) は高 $\mathrm{Cl}$ の石炭を 使用した場合生ずるデポジットによるマルチサイクロ ン集ジン器閉塞防止方法として次のことをあげてい る。（1）ガス大ロにスートブロワをつける。(2)各少 イクロンのガス出口にピッタリ入るコイル状スクレパ を大れて掃除を完全にするようにする。

Crane氏ら14)は操業中のボイラに批て,デポジット を採取する装置扎よびブポジットの分析方法について 研究している。Dolzal 氏15)はスラグタップ炉のスラグ によるレンがの破損をフインのある裸水管を用いるこ とによつて防止した。フインのない裸管はスラグが管 のまわりに付着し，やがて管下部のレンがに破損が生 どたが,フィンのあるものを用いたところ 4,000 時間の
操業後もレンガに何んらの異状も認められなかつた。 次にわが国で新らしく採用された然焼機としては ルーベー型ストーカがある。使用者 ${ }^{16)}$ の経験による そ，このストーカは火層への空気の分布はストーカの 長さ方向のみならず，巾方向に抢いても調整ができ， 良好な燃焼がえられ，かつ故障も普通型のストーカに 比へて少ないなどの利点をあけてている。

特殊な熱管理的研究としては，前沢氏17゙が行つた， 水中燃焼がある。都市がスおよび発生师がスを使用し て, 蒸発効率 80〜90\% を元，また西硫酸パルプ廃液 を固形分 $55 \%$ まで問題なく濃縮することができた。

今年度は大型ボイラなどに不定形炉材汃大いに潽及

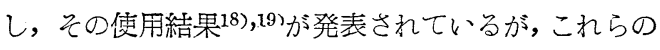
ものについての経験が浅いため, 使用場所に応したも のを選択し，その施行方法にも注意を払い，適当な焼 結温度をとらなければ本来の性能を発揮できないわけ で, 今後これらのことについてさらに深い研究が必要 であろう。

各種産業における排熱の回収については多くの研究 がある。小松氏ミ0引は緎維の加工行程において, ヒート ポンプを用いる排熱利用について検討しており，田中 氏911は都市ガス製造行程において，サイロックス脱硫 器の加温に要水縮器の排温海水を利用して大きな效果 をあげた。その他, 硫安の乾燥に煙道排ガスの利用22) ジム工場に括けるドレンの回収 ${ }^{23)}$, 陶嗞器焼成トンネ 儿案の排熱の乾燥への利用 24$)$ ，溶銑炉の然焼用空気予 熱に，排ガスの利用95)など排熱の回収には各方面にお いて，多くの努力が払われている。

\section{交献}

1) U. Kraus \& W. Grimm, B. W. K. 7, 6, 254 (1955).

2) 山田，石井 資源技術試験所報告 No. 30 (1955).

3) 熱管理, 7, 4, 19 (1955).

4) Ooll. Guirad., 191, 4923 (1955).

5) 勝部, 燃協誌, 34, 344, 695 (1955).

6) 境田, 蓺管理, 7,6, 13 (1955).

7) 宗像, 佐川; 燃協誌, 34, 340, 490 (1955).

8) E. J. Macdonald \& M. W. Murray, J. Inst. Ficel., 28, 177, 479 (1955).

9) A. E. Mordin, J. Inst. Fuel, 28, 176, 451 (1955).

10) T. F. Hurley \& L. J. Flaws J. Inst.Heat. Vent. Engrs. 23, April, 1 (1955).

11) Lees, J. Inst. Fuel, 28, 176, 433 (1955).

12) P. H. Crumeley,A.W.'Fletcher \& D. S.Wilson, J. Inst, Fuel., 28, 16950 (1955).

14) W. M. Crane, A. W. Lindsay \& G. G. Thu- 
rlow, ibid., 28, 173, 291 (1955).

15) R. Dolzal Comb., 26, 7, 43 (1955).

16) 高阁, 燃料及燃燒, 22, 5, 38 (1955).

17) 前沢, 然協誌, 35, 346,77 (1956).

1S) 䫅本，燃料及燃堯，22，6，31 (1955).

19) 塚本，燃料及燃燒，22，7，658 (1955).

20) 小松, 熱管理, 7, 10, 47 (1955).

21）由中， $7,11,17$ (1955).

22) 堀, " 7, 11, 9 (1955).

23) 茶谷, " 7, 11, 20 (1955).

24) 砂川, " 7, 11, 38 (1955).

25) 沢晶, " 7, 11, 47 (1955).

\section{動力源の調查開発に関する情势}

\section{1. 昭和 30 年度の電源開発の進捗状況}

昭和 30 年度の電源開発工事は, 昭和 29 年末に決 定した電力 5 タ年計画にもとづいて実施された。この 5 ケ年計画は昭和 33 年度夿目標年度とし; 目標年度 の想定需要電力量 575 億 $\mathrm{kWh}$ を充足卞るために，昭 和 29 年度から 33 年度までの 5 ケ年間に 460 万 $\mathrm{kWh}$ を開発せんとするものである。本計画にもとずく昭和 30 年度の要開発工事量は, 炤和 29 年度加らの継続工 事, 約 290 万 $\mathrm{kW}$ ，略和 30 年度の新規着工工事，約 140 万 $\mathrm{kW}$ ，合訐約 430 万 $\mathrm{kW}$ であつて，これに要す る開発資金は, 発電, 送電, 变電, 配電, その他す心 て含めて約 1,700 億円である。この開発の主体は 9 電 力会社, 電源開発会社で, その他若干の公営, 自家発 電業者が当つている。炤和 30 年度に運転を開始した 発電所は，上記工事量のうち約 140 万 $\mathrm{kW}$ であつて， 残りの工事は炤和 31 年度に引続き行われる。完成し た発電所の内訳は，水力発電所約 80 万 $\mathrm{kW}$, 火力発 電所約 60 万 $\mathrm{kW}$ であつて, 開発量では戦前, 戦後を 通して年間開発量の最高記録になつた。昭和 29 年度 も約 120 万 $\mathrm{kW}$ の開発完成量があつたので，29 年度， 30 年度は戦後の電源開発の一つのピークを形成して いることになる。昭和 30 年度の開発て特に注目すへ きことは(イ)新鋭火力の建設である。水力開発地点が 次第に割高になつたことと，石炭価格が低廉になつた ことなどから水火力発電原価が接近して，火力発電の 有利性が増大した点から，9電力会社ではこぞつて， 高温高圧の新鋭火力の建設に重点をそとぎ，もつて設 備の近代化と，電力原価の高騰を防止さんとした。米 国から輸入した，例の火力借款として世を騒した三重 (中部電力), 则田(九州電力), 多奈川(関西電力)の三 火力発電所は昭和 30 年度に次々之運軽を開始し, こ
のほか, 更に東京, 筃西, 中部の三電力会社では, 世界 の最先端党ゆ人気圧 $100 \mathrm{~kg} / \mathrm{cm}^{2}$ 以上, 気温 $550^{\circ} \mathrm{C}$ 以 上，熱功率 $35 \%$ 以上の新鋭火力の輸大を訣つている。 これら火力は一機の出力が 15 万 $\mathrm{kW}$ 以上でわが国と しては，発電機ニニットの大いさとしては画期的のも のである。このように火力の建設に重点をおいた結果 昭和 20 年度の新規着工工事内䚿流, 水力発電所約 30 万 $\mathrm{kW}$, 火力発電所約 110 万 $\mathrm{kW}$ となり，火力のウ土 イトが圧倒的に大きく, 従来の水主火従の常識在打ち 破つている。この方向は, わが国の包蔵水力の現状か ら必然的のもの之考元られるので, 今後も同様の傾问 を巡るであ万う。(口)炤和 30 年度には上椎葉水力発 電所が完成し，佐久間ダムが湛水を開始した。前者は 本邦最初のアーチダムを採用したもので, ダムの高さ $110 \mathrm{~m}$, 発電所出力 9 万 $\mathrm{kW}$ である。後者は, 電源開 発会社が全力苍あけて開発に当つたもので，難工事を 克服して，ダム死建設し 30 年末湛水を開始した。昭 和 31 年 5 月に一部発電開始が予定されている。出力 は 35 万 $\mathrm{kW}$ であり, 東京電力, 中部電力に送電され る。

\section{2. 新電力 6 ケ年訢画の策定}

経済 5 タ年計画に並行して電力 6 ケ年訫画が新たに 昭和 31 年 1 月の第 19 回電源開発調整審議会で決定 された。本計画は, 経済 5 タ年計画の目標年度, 炤和

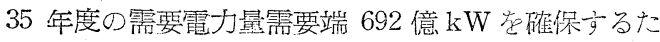
め, 昭和 30 年度以降, 昭和 35 年度までの 6 ケ年間に 約 500 万W の䦥発を完成せんとするものである。 このうち水力!約 343 万 $\mathrm{kW}$ ，火力 257 万 $\mathrm{kW}$ 之予 定されている。この開発に要する資金は, 送变配電工 事拉よび改良工事をあわせて総客約 9,991 億円(内, 外 資予定分 73 億円) である。昭和 31 年度以降は本計 画に沿つて開発が実施される。

3. 原子力発電に対方皇期待

わが国の電力は主として水力, 火力発電所て供給さ れているが, 現在の需要增加状沉からすると, 今後 10 年乃至 15 年以内に原子力発電が期待せざる龸得な くなるであううと考劣られる。試算によれば次の通り である。現在の電力需要は年 $9 \%$ の増加率を示してい るが，今後次第に增加率が逓隇するもの之考元，1975 年には $3 \%$ になるものとしても； 15 年後には現在の 約 2 倍, 20 年後には約 2 倍半の需要量に達するもの と推算される。この需要に応ずるためには，毎年約 100 万 $\mathrm{kW}$ 程度の開発㕝行う必要があるが，これに見 合うェネルキ資源は，現在のところでは経済的開発可 能包蔵水力は約 1,700万 $\mathrm{kW}$ ，といわれているので， 
今後 15 年程度で主要な水力資源は開発し尽されるこ とになる。また火力発電については，日本の国内生産 石炭の火力発電に振り向けられる限度を一応 1,500 万 $\mathrm{t}$ と考光れぱ, 火力発電もまた, 今後 10 年を出ずし て石炭供給力の面から限界に達方るものと思われる。 これらの点から 10 年乃至 15 年後には新規のエネル ギ資源一原子力に頼らざるを得ないもの之考えられ， 現在との準備態攀が急がれている。なお試算の前提に なる包蔵水力の限度については種々議論のあるところ で明確な経済的限度花得るため, 包蔵水力の再調査が 要望される。通商省ではこの線に沿つて, 昭和 31 年度 から向う3タ年間に包蔵水力の大規模な調查を実施主 る計画を樹てている。本調査完成の後は, 原子力発電 に期待する時期を相当明確に論じ得るようになるであ ろう。

\section{原子カ問題の趨勢}

1955 年こそ原子力平和利用の問題では世界的にも, また日本にとつても真に劃期的な年であつた。夏のジ ュネーブ会議を契機として，従来秘密のヴェールに覆 われていた諸問題が大巾に公開され，水素融合反応研 究すら洩らされるに至つた。日本ではアメリカとの協 定ぶ正式に締結され，い上小上研究へスタートする準 備ができ上るとともに，ジュネーブ会議に刺战され， 国内の原子力閣題がとみに喧伝されるに至り，原子力 基本法の制定, 原子力委員会, 原子力研究所の発足な

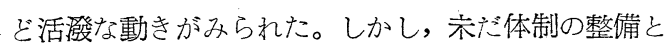
いう段階であつて，実質的な研究はほとんど進まず， 特に報告するような事項がないいけ残念である。従つ てここには研究項目に触れず，一般的なすう勢を解説 军る!止める。

\section{1. ジュネーブ会議}

8 月 8 日から 2 週間ジュネーブにおいて開催された 原子力平和利用国際会議は参加国 73 , 参加代表(オブ ザーバーを含み） 2,800 人という国運始まつて以来の 大会議であつたが，実質的にも真に歴史的なものであ つた。

これより先 2 月イギリスは原子力発電 10 年訐画と いう大胆な長期計画を発表し, ソ連は 7 月 1 日からを スクワに原子力会議を開催し, 従来秘密にされていた ソ連の原子力研究の成果を公表するなど, 積極的な動 きがあつた。さて，ジュネーブ会議開催に当つて，米
ソの政治的な対立坊最も憂慮され，そのため国連事務 当局な会議運営について，箃重な規定を設けた程であ る。ところが会議は終始友好的に進められ，しかす， 予想通り米側も研究成果を相当積極的に公表し，さな がら競争的な公表という結果になり, 最早平和利用に 関卞る研究結果の秘密保持意味引ないという意見さ え出るに至つた。こうしたふんい気に影響され，米国 の政策が大ゆに変化してきたことは事実である。ジュ. ネーブ会議で出た大きな䦓題をひろつてみると，

（1）水素融合反応研究の Suggestion

（2）速中性子炉に関方学表

（3）廃妄物処理に関する報告と討論

(4) 遺伝学的影響について

なお，会議の最初の日に発表されたアメリカの濃縮 ウラン貸与料 25 ドル/ $\mathrm{U}_{233} 1 \mathrm{gr}$ 和よで重水価格 28 F゙ ル/lbは世界的に大きな反響をもたらした。

さて，秋に至りアメリカで 2 つ大きな原子力閔題 の会議が開墔され（すなわう Atomic Industrial Forum 抢よび National Industrial Conference Board）ジュネーブ会議の結果に鑑み，アメリカ原子力 法の適用を緩め, 機密を解除し, 民間の研究を促進卞 べきことが強調された。また水菜融合反応もテイリン グ，抢よびスマイス両氏により発表が行われた。

2. 原子力協定

アイゼンハウアー大統領により提案された，U-235 $100 \mathrm{~kg}$ 原子才研究のため貸与するという構想は, ジ ュネーブ会議を前にして，急速に具体化して行つた。 すなわう，米国に対抗しソ連文共座国に対し同様の提 案をなし，7 ケ国に対し接術援助の協定を終り，7月 のモスクワ会議を迎えるに至つておつたのである。ア メリカ側も自由諸国家に対し, 積極的な態度て臨み, ジュネーブ会議開催までに 21 ケ国と調印を終り，7 ケ国と仮調印范終るまてでこぎつけた。

日本で正式に此の問題ととりくんだのは4 月で, 爾 後政治的ないろいろな問題があつたが 6 月 21 日に仮 調印を了し，11月 14 日正式調印を行つた。かくて原 子力平和利用のための, 一般的な協力協定が成立し, アメリカの援助が正式に期待されるに至つた。

この協定により，まず 1956 年 3 月アメリカより

W. B. 型原于炉購入の契約がなされた。

なお, 最近アメリカで濃縮ウラン $20 \mathrm{t}$ の海外放出が さらに提案されたので，1956 年はその問題が具体的 になつて行くであろう。

3. 原子力開発の体制

原子力協定仮調印:二伴、、研究実施機関の確立が主 
張され，11 月末暫定的に財団法人原子力研究所が発 足した。恒久的なものとして，これを国立にすべきか 公社にすべきか，または特殊法人にすべきか，各種の 論議が行われたが，ついに特殊法人とすることとなつ た。な抢, 統括機関としては 1 月 1 日原子力委員会か 誕生し，同時に総理府に原子力局が新設された。実施 機関としては研究所の外に原子燃料会社の創設が洘え られている。

法制の問題としては 12 月に原子力基本法が制定さ れ，近く核燃料資源開発促進法が予定され，その他前 記諸機関設置法の問題がある。

さて, 今後の開発の方向としては 11 月原子力利用 準備調查会において，基本計画が策定され，近く原子 才委員会により修正されるであろうが，目下のところ 前記計画に基いて開発が進められている。すなわち, 本年 $50 \mathrm{~kW}$ の W. B. 型原子炬觉, 来年 $\mathrm{CP}-5$ 型の 原子炬をそれぞれ米国より購大設置し，第 3 年目に熱 出力 1 万 $\mathrm{kW}$ の天然ウラン一重水炬を国産技術により 完成することになつている。国産といつても材料関係 はほとんど間に合わず，輸入に偖存することになるで あろうが，日本人の設計で独力で組み立ててみるとこ ろに目的があるのである。

かくて，体制もでき上り方向も示されたので，本年 こそはいよいよ内容的な整備に移るであうう。

\section{地 熱発電の趨勢}

前回には日本の地熱開発計画の概況を述べておいた が，その後開発調查が思うような進展をみせていな い。天然蒸気が出ないというわけではなく，穿孔が進 まないため進展しないのである。たと光!゙大分県大獄 で実施しているボーリングでは約 $360 \mathrm{~m}$ の深度まて掘 つたが堪无間ない崩壤のため道具をしばしばとられ， ケーシングを入れることさえできず難溜している。ま た群馬県草津殺生ケ原のボーリングは深度 $150 \mathrm{~m}$ で 硫化帯の硬質盤に突当りその先が掘進できない。要す るに穿孔技術て悩んているというのが現状である。こ れに関しては目下九電, 東電両 K.K. でも最上の工夫 と背水の妢力を払つているので，今暫人様子をながめ て待っことにする。ただ特筆ししたいのはその熱意の あらわれとして電源調査会後援の地熱開発委員会では 来る 5 月頃本邦の地熱地をみせて意見を聞くために仏 人ブルースEを招聘する予定と聞いている。同氏は伊 太利地熱発電の権威であるから，日本の地熱地に対し
て或程度の暗示と判定をして貫う機会を得ることは, われわれにとつてもこの上ない意義深いことである。

さて本論に戻るが今回は伊太利の地熱地と日本のそ れとを比較対照して，日本のはとんな構造かを紹介す ることにする。但し断つておきたいのは地下における 天然蒸気構造図は永久に証明はできないし，調查する にしても多大の犠牲を覚悟しなければならないのであ る。従つてここで述へることは筆者の最近 10 年間に 得た資料に基いた持論であることを前置きしておく。 そして天然蒸気に関しては世界に抢いて交献がただ伊 太利のものだけに限られる関䌽上，独断的に宿り安い から充分な検討を必要とすると思われる。

伊太利の地熱源

鉱山師がその露頭から鉣床を発見するように，伊太 利でも蒸気露頭からその深部の構造を度重なる岈孔に よつて推定したものに違いない。ラルデレロで成功し たからナ亦りの近くのぶスビアス火山簏の地熱地でも 成功するかと思って穿孔したが， みごと失敗したとい われる。その原因を追求してみると, 孔底の温度は $200^{\circ} \mathrm{C}$ 近くもあつたけれども，中は蒸気でなく湯であ つたということである。湯から出る蒸気では発電技術 に種々な困難を伴う。幸にラルデレロでは年間の雨量 が少く，地表水は抢乃か地下水もないので地下の蒸気 には湯が混つていなかつた。それだけではなく地下水 がない打蒢で第孔が少し深くなると過熱蒸気が出てく る。そして蒸気の賦存状態は割目の形, 大いさだけに 関係するから，蒸気溜りが仮りにあつてもその溜りの 形に随つて蒸気が分布するから, 溜りの位置, 大い さ，形を決めることによつて構造が出てくる。伊太利 の報告書による之他のいかなる物理探査方法も䭾目で あつたが，唯電気探査だけは相当に役立つたといつて いるのは，断層空陸を捕捉するのに或程度電探が有効 であるからによるのかも知れない。日本は伊太利とそ の点が根本的に相違する。日本は雨量が非常に多くて 古来瑞穂国といわれる位だから，とこの地熱地といえ ぞも地下水が熱源の上部にある。熱源は蒸気を上に矨 上け，地下水は上から下に向けて匠しさげ，蒸気と水 が互に平衡を保つている。単に蒸気と割目との関係だ けではなく地下水との関係をみなければならぬから 3 次元である。これが伊太利ラルデレロのと根本的に違 う点であることを特に強調しておく。

ライフ誌に発表された伊太利の地熱地構造四は第6a 四のごときもで，その説明をみると地質学的のこと が詳細載つているが，その骨子とするところは或る程 度深い所のたとえば地下 $1,000 \mathrm{~m}$ 位のところに地球内部 
第 $6 \mathbf{a}$ 図 伊太利ラルデレロ天 然蒸気の地下構造図

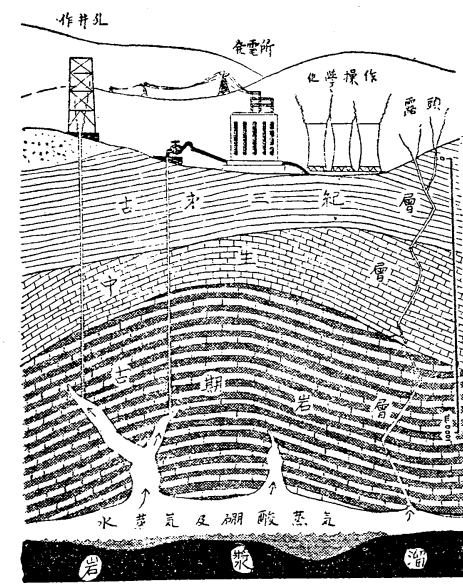

の愹融体即ち岩漿がある溜りを㹉えていて, これから 発する水蒸気がその上層に溜り, 蒸気溜りを作つてい ると考えている。最も重要なことはこの蒸気溜りが岩 漿溜りと別々にあつて，両者が割目て繫がれているの でなく岩漿の上層すなわち蒸気層であるとしてある。 ぞうしてそう考える必要があるかというに，無数に穿 孔しても蒸気量は少しも減少しない理由と, 第7 図に 示したように岩漿り溜と蒸気溜りが別々ならその繫が

\section{第 7 図 蒸気溜と岩漿溜との関係}

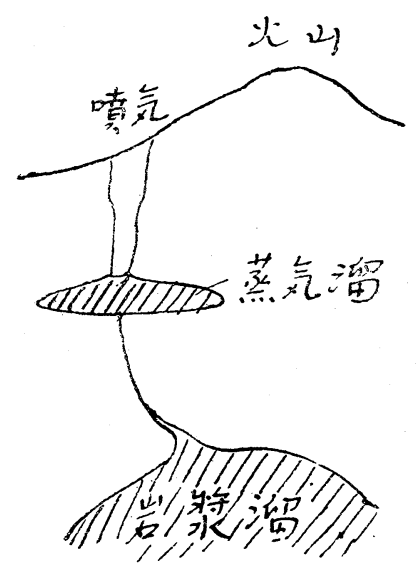

りの割目を流れる蒸気量以上には取れないから，少し も減少しないという事実と矛盾するからである。それ からもう一つラルデレロでは Argille scagliose とい う第三紀の粘土層があつて蓋の役目を果しているか ら，掘れば出るが，日本のはすでに蓋がとれていて烝 気は技殼であるという説が日本のある学者によつてい われている。成程日本の地熱地では噴気孔が多数あつ て長い期間それから蒸気を噴出したとすれば，熱源の
第 $6 \mathrm{~b}$ 図 日本地熱地の地下 構造推定図

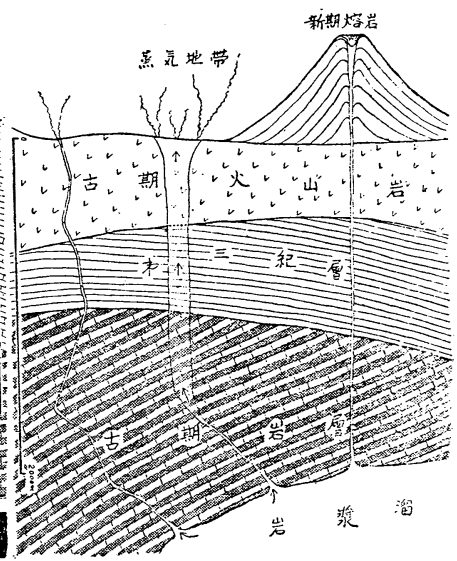

冷却速度は割合に早かつたかも知孔妨。ししラルデ レロの四をみても立派に噴気露頭はあり, 日本の之大 して違わない。強いて違うとすれは蒸気噴出の程度の 問題であると思う。日本の学者の中にはかかる蒸気の 抜けた地熱地などはねらわないで抜けない地熱地をさ がすよう主張する向もあるが，それは後章に述へる日 杰の地熱地の構造をよく理解して鿓えれば，われわれ が嘪気露頭の上を穿孔するよう主張する理由がうなず かれると思う。

\section{日本の地熱地の構造}

日本の著名な地熱地たとえは箱根, 別府, 雲仙, 登 別などにしても，強烈なものは地熱地として共通した 特色が多数ある。すなわち天然蒸気の露頭範囲には或 る限度があつて，これを越えると地温がなくなる。求 気带一面には必らず㜔けを生じており，その焼け土は 珪酸質白土別名粗珪石である。粗珪石分布地内から出 ている蒸気露頭は大小一定しないが，少くとも 1.2 ケ 所には乾燥蒸気(過熱)を出している程強烈なものがあ る。強烈な噴気の上を川の流れが通過しているところ では川氷は盛んに踊つている割合に水は高温となつ ていない。これらの蒸気帯の周りには湯带があつて著 名な温泉地をなしている。揚の涌く所ではそのまま 洗湯に使つて抢り，蒸気の出るところは別に水を引、 て注入し，湯を作つて温泉だと称している。

以上が地熱地のの表面のありかたであるが，これと 別に地下断面を考えてみる。噴気露頭の側を穿孔する と深度に対する地温は第 8 図に示したように地温勾配 が始め急で或る深度に達するとそれが湲かになり，そ のまま長く続いてゆきこの傾向はどこの場合でも大 体成立つている。これ定理論で説明方ると次のごとく 
第8 図 調査孔測溫図

A 大分県别府白望 B 大分県野矢

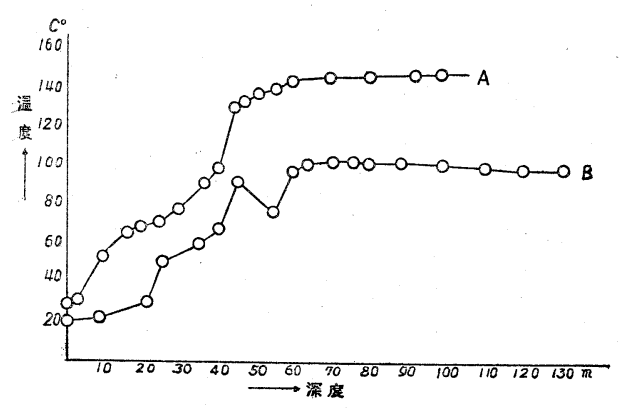

第 9 図 地下における天然蒸気の溫度と圧力

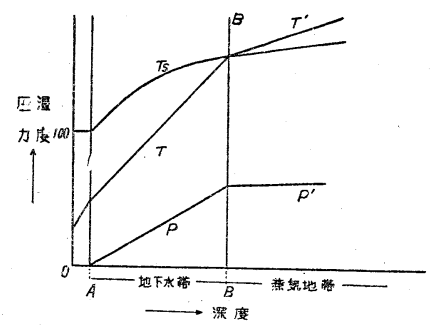

なる。

地熱地域の中心部の地表に近い部分では熱の流れは 地表に直角方向に平行であると考えられるから，地質 が一様であるとすれば，地下水带に括ける温度勾配は 第 9 図Tのごとく直線的であるはずである。但し $O$ は 地表，Aは地下水面である。また岩石の罅吵を充填し ている水の圧力は水の流動の影響を無視すればほぼ静 圧に等しく，從て同図Pのごとく直湶的になるはずで ある。 $T_{s}$ 曲葲は $P$ なる圧力に相当する館和蒸気の温 度であるとし， $T$ か $T_{s}$ 曲瀪と $B$ 点に扎いて交わる場 合にはB点より深い地点では氷としてでなく蒸気とし て存在しなければならない。従てBは皮と蒸気との境 界面である。天然蒸気は地球の深部から岩石の割目を と抢つてB面まで上昇し，ここで凝結して潜熱存発し その熱が伝導によつて地表に伝わるのであるから，蒸 気地带の温度を $T^{\prime}$ とする時, $B$ 点附近において $T$, 曲線の傾きは $T$ 曲線のそれよりも遥かに小でなければ ならない。しかし $T^{\prime}$ 曲線は $P$ 曲線の延長よりも下 にくることは許されない。また蒸気带の圧力 $P$ につ いて考えるに，岩石の割目の程度にもよるけれども， 蒸気の流れは一般にきわめて緩かであるから， $\mathrm{P}^{\prime}$ 曲 線の傾きは非常に小であると言える。従て天然蒸気は 地球の深部では過熱蒸気であつて，それが次第に冷さ れつつ上昇し， $B$ 面に達した時初飽和蒸気にな る。以上のことを要約すると地熱地带地下には地下水 帶と蒸気带があつて, 両者は適当な温度圧力のもとに
平衡が保持されているといえる。(この説明は奥田氏 の論文より弓用したものである。）

しかるに熱源には非常に弱いものと強いものとがあ つてすでに冷却が進んだものは上に述へた蒸気と地 下水の界面が遥かに深いところへ降下し，反対に熱源 が強烈なものは蒸気が地下水を突破して地上に噴出し 噴気孛作る。またその強烈の程度によつて噴気の数は 殖え噴気面積が広くなる。第10図は略々均質な割目の ある地下における蒸気带と地下水带の関䋆虏一般的に 表わせるもので, 主蒸気道が地面に垂直に書いてある がこれが多少横這つても蒸気帶の形状は深さに対し 細長いものとなる。

\section{第10図 地熱地帯地下理想断面図}

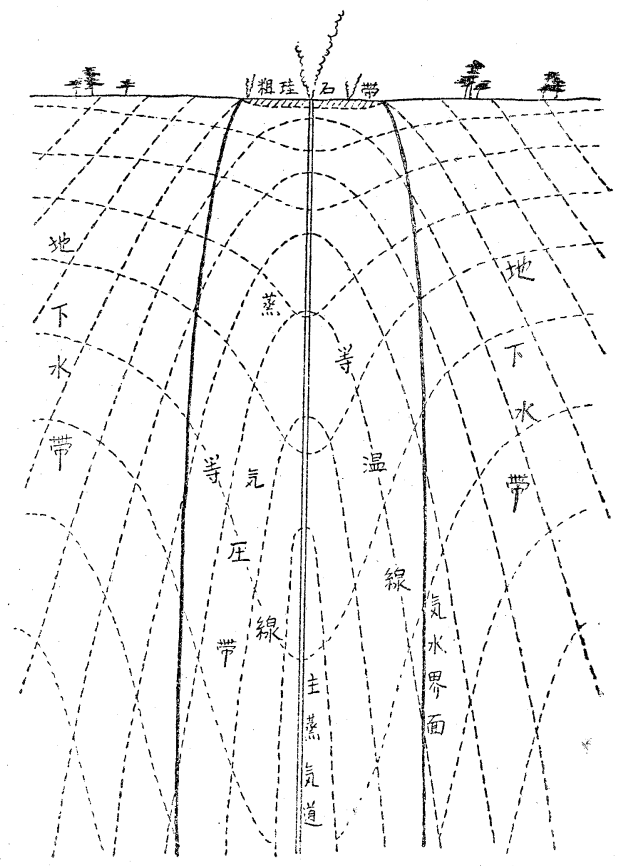

ここで特に面白いと思われることは, 爇源が強烈で あればある程地上近くでは噴気道が広がり，蒸気带の 形状が頭でつかちとなる。第11図は宫崎県海老野温泉

\section{第11図 宮崎県海老野地熱地断面における} 蒸気と湯との関係図

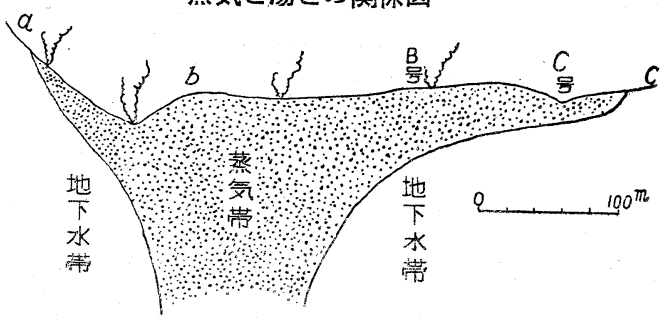


第12図 万座溫泉における蒸気道の遺跡 (白色筋状の\&のが蒸気道)

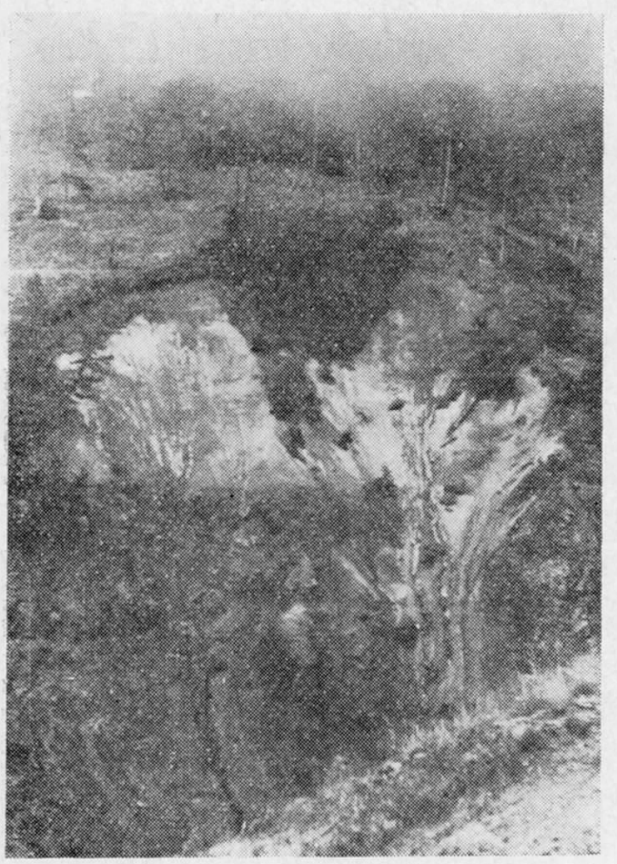

で調査した結果から得た実例で理論を裹付けるに最も 好都合なものである。この外に実証に足る例がまだ多 数ある。群馬，長野両県境にある万座温泉では第12図 にみるこ゚とき蒸気道の遺跡がはつきり残つているのを 発見した。今は冷却して温度はないけれとも，その昔 高温の蒸気が出ていた当時は下からくる蒸気は地表近 くて扇状形に開き, 蒸気道に粗珠石な白く残している。 こんな例は稀にみることで地熱地带の地下構造を説明 するに実に貴重な資料である。地熱地て呀孔すると先 に蒸気が出て，段々深度が増すと湯になることがしば しばある。この事実を捉えて簡単に高温の湯から蒸気 ができるかのごとく主張する学者もあるが，実はそう でなくて蒸気带の形状を理論的にも実例的にも出すと その間違いであることが了解せられる。結論としてい わねばならぬことは，日本の地熱地の構造はどこまで も水と苜気と割目との関係ででき上つているというこ とであつて，その構造は第10四のごときものである。 そして地下深処までその形状が続いていて，強いてそ の深処まで推定するならば第 $6 b$ 四のごときものであ ろう。

\section{交献}

1) 奧田克巳, 世界動力会議第 4 回諭文集, 昭和 25 年

2) 三土知芳, 地学雜誌, 第63卷, 第 2 号 (1954).
3) 近藤信興, 安藤武, 地学雅誌, 第 62 先, 第 2 号 (1953).

4) 近藤信興, 地学雜誌, 第63卷, 第 4 号 (1954).

5) 近滕信興, 地犋調查所月報第 6 枩第 10 号 (昭和 30 年)

\section{太陽熱の利用の趨勢}

世界の人口は年々増加し，また人間 1 人あたりのエ ネルギの消費量も年々増加しているので, 1 年間に世 界中で消費されるェネルギの量は加速度的に堌大して いる。凡らく次の 100 年間に $80 \sim 400 Q\left(Q=10^{18}\right.$ Btu $=0.252 \cdot 10^{18} \mathrm{kcal}$ で発熱量 $7,000 \mathrm{kcal} / \mathrm{kg}$ の石崖 360 億 $\mathrm{t}$ に相当する）位を必要とするであろうといわれて いる。しかるにェネルギ源の方は燃料の埋蔵量は $27 \mathrm{Q}$ 位 (石宸 $21 \mathrm{Q}$, 石油と天然元ス $5 \mathrm{Q}$, その他 $1.2 \mathrm{Q}$ 位) でこれのみな使用すれば今後数十年で消耗してしま うことは明かである。幸にも最近埋蔵量から 500〜1,000 $\mathrm{Q}$ もあるとみられる原子ェネルギ源(ウラニウム，下 リウム）の利用ができるようになつたが，それでもこ れは今後数百年間のエネルギ清費を支えるに過ざない であろう。これらの埋蔵資源は一度使えばなくなつて しまうものであるから，どうしてもいくら使つても更 新される循環資源によつて埋蔵資源を補つて行くよう にする必要がある。次の 100 年間に使用し得るェネル ギの循環資源としては, 薪炭類 $2.4 \mathrm{Q}$, 風力および水 力 $0.7 \mathrm{Q}$ 位で大したことはないが，しかし太陽熱は利 用のしかたによつてはほとんど無尽蔵といえる位多量 にある。いま上けた数字から考えると，今後はできる だけ太陽熱を利用して行かねばならないことが眀らか である。太陽熱は比較的低温度で利用するのが比較的 安価な装置で効率よく行うことができて，一番有利で ある。米国の調査によると, 每年使用される然料の約 40\%は暖房, 給湯などの比較的低温度における熱の 利用に使われているという。このような方面に太陽熱 を利用することは割合に容易である。特に給湯の方面 では太陽熱は現在でも燃料と経済的に競争ができる状 態にする。

太陽熱利用の方面を大別すると, 熱的利用, 電気的 利用, 先化学的利用の 3 つにな。爇的利用には 2000 〜 $3000^{\circ} \mathrm{C}$ の高温度における利用, $200 \sim 300^{\circ} \mathrm{C}$ の中温 度における利用, $50^{\circ} \mathrm{C}$ 前後の比較的低温度における 利用や農業方面における利用などがある。電気的利用 としては太陽電池があり, 光化学的利用としてはクロ レラ (藻類) の急速栽培や水の分解および光合成など がある。

1.太陽熱の熱的利用 
$3000^{\circ} \mathrm{C}$ 前後の高温度は太陽师によつて容易に実現 することができる。すなわち，硝子または金属製の鏡 て回転放物面を作り，それを太陽に向けて光線を焦点 に集中すると $3,00^{\circ} \mathrm{C}$ 前後の高温度が得られるから， これによつて耐熱鋼，耐火材料などの試験や，宝石の 加工などを行つている。普通は直径 2 $3 \mathrm{~m}$ 位のもの であるが,フランスのピレネー山上にある直径約 $11 \mathrm{~m}$ (35 呎) のものが現在世界で最大であり, 容量は 75 $\mathrm{kW}$, 鉄を $66 \mathrm{~kg} / \mathrm{hr}$ の㓶合で融かすことができこれ は半工業的に使用されているという。普通の太陽炉は 太陽の移動に従つて区射镜を動かしてその中心線を常 に光線の方向に一致させているが，フランスのピレネ 一山上の太陽炬は巨大であるために，放物面の反射面 は固定して捣いて，その代り平面の反射面を別におい て，それから反射した光を放物面の反射面に入れるよ うにしている。探照燈を太陽师に使用することもでき る。かが国では名古屋の工業技術試験所て直径 $2 \mathrm{~m}$ の 太陽炉が製作されて目下試験中であり，また東大では 直径 $4 \mathrm{~m}$ 位の太陽版を製作する計画がある由である。 なおフランスては直径 200 尺の巨大な太陽师つ製作を 計画中であるそうである。太陽炉にはレンズを用いて 集光する型式もあるが，レンズが高価であるためにこ の型式のものは高価となるのて, 米国のカリフォルニ ヤ工科大学 (CIT) に直径 2 吹のレンズ 19 個な用い て $3,500^{\circ} \mathrm{C}$ を実現するもの以外は例をみないようであ る。直径 $2 \sim 3 \mathrm{~m}$ 以の太陽师は現在世界全体として 20 〜30 個製作されている程度である。

太陽熱を利用して動力を起す太陽熱機関や，食料党

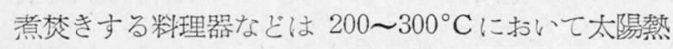
苍利用する。太陽熱機関は普通放物線の断面を持つ細 長い反射面の焦点位置に水管なおき，太陽熱によつて 蒸気をおこし，その蒸気苍蒸気機関またはタービンで 膨脹させて動力を発生する。この場合にも反射面の軸 老常に移動させて太陽を追跡することが必要であるの で，構造は面倒になる。それで動作物質として亜硫酸 ガスやェーテルのような揮発し易い物質を用いて，平 面の受熱面で太陽熱を吸収し， $40^{\circ} \mathrm{C}$ 前後の比較的低 い温度て蒸気を発生し,これを機関て膨脹して動力を 起すものもある。この種の機関は大抵地下水を汲上け る井戸ポンプの運転に用いられ，汲上げた冷たい水で 機関からの排気を椧却して㠜縮させている。従つてこ の機関は次の比較的低温における利用の方面に属する ものである。太陽熱機関はまだ寒用の域には入つてい ない。これまでに実験されたものとしては, 細長い放 物面の反射面を利用した太陽熱機関では土ジプトのカ
イロ市の附近にシューマンとボイス両氏により 1913 年に建設された $60 \mathrm{PP}$ のもの, アボット氏が 1936 年 にワシントンで開催された国際動力会議に出品した $0.5 P$ のものなどが有名である。これに対し平面の受 熱面を持つものとしては，1907 年にシューマン氏が フィラデルフィアに作つたェーテルを使用した $3.5 \mathrm{P}$ の機関，昨年米国のアリゾナ州で開催された第 1 回国 際太陽熱利用会議に出品した $1.5 \mathrm{PP}$ の互硫酸ガスを用 いた機関などが代表的である。

太陽熱による料理器は多面䍌や金属板て回転放物面 またはそれに近い面の反射面を作り，その反射先線を 鍋や釜に集めて，これ苍煮焚きするに必要な温度に上 げるようにしたものである。わが国では五藤齐三氏に より 34 枚の硝子製平面鏡で多角形椀形反射面（直径 $1 \mathrm{~m}$ ) の料理器が試作実験された。反射面の焦点位置: に金属製釜苍置きこの上に硝子製バルジャを被せ，4 月上旬の快睛の日に $12^{\circ} \mathrm{C}$ の冷水 $4 \mathrm{~kg}$ 占 1 時間余り で沸騰し， 1 升の飯が 1 時間半て炊けた。第13図はイ ンドて試作された湯沸し器で, 反射面からの反射先線 が湯沸し器の底部に集中するようになつている。米国 のニューヨーク大学のマリャテルクス教授(婦人)は沢 山の料理器や天火苍試作し昨年の第 1 回国際太陽熱利 用会議の展示会に出品されていた。併し太陽熱料理器 もまだ試験時代で実用にはなつていないようである。

比較的低温度 $\left(50^{\circ} \mathrm{C}\right.$ 前後)における熱的利用面と しては温水器, 蒸溜装置, 暖房装置などがある。温水 器は種々の太陽熱利用装置の中て現在最も広く普及し すでに実用の域に大つている。米国のフロリダ半島だ けで 3 万個余り使用されているといわれるから，全米 では 4 万個余り使用されているものと思う。わが国で も愛知県だけで 2 万個以上使用され，その他関東地方 およびそれ以南の中部, 関西, 中国, 四国, 九州の各 地て使用されかけているから，全国ではすでに 3〜4 万個使用されて いると思うし， その数が急速に 増加しつつあ る。わが国の前 記諸地方では， 緯度は米国のア ワゾナ州に相当 して太陽熱の強 さも比較的強い のと, 日本では 諸外国に比較し

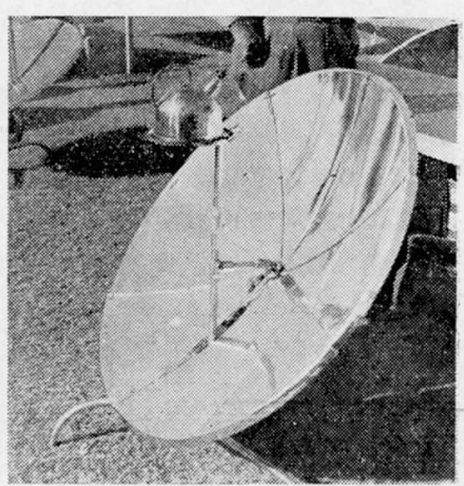


て燃料の值段ぶ高いので, やり方によつては太陽熱温 水器を使用する方方燃料を使用少るよりも経済的であ るので, 温水器の普丈は特に有望である。また農林省 の生活改善課の努力が, 温水器の農村に普斗する上に 功績があることを忘れてはならない。また温水器には 沢山の種類があつて, 構造簡単な安価なものが農村に 普及し，また比較的高価でも能率よくかつ冬期でも便 用し得る永久的なものが都会地に普丈する傾向があ る。なお温水器はオーストラリア, インド, パキスタ ンイスラェル，北アフリカなどでも使用されかけて いる。

米国の西南部や北アフリカなどでは水が不足して， 土地があつても農地として使用されないとか，その他 種々の点で非常に因つているようである。それで太陽 熱により海水を蒸溜して真水を作る研究が盛んにかつ 大規模に行われており近く㫪用の域に入るようである。 太陽熱による暖房の研究も一部で行われているが, まだ寒用されているものは 1〜2 の場合を除いてない ようである。

2. 太陽熱の電気的抢よび光化学的方面における利用 最近純粋なシリコンを主体とする太陽電池が米国で 製作され, 日光から電気エネルギに変るその效率が 11\%に達し，非常に注目されるようになつた。この 太陽電池は将来必ず通信などの方面には実用になると 思うが，現在では高価であるのて，これを一般の発電 用に用い得るか否かは未知数である。

太陽熱によりクロレラを急速栽培することは世界的 に研究されているが, 特にわが国の徳川生物化学研究 所では炭酸がス孝吹き込みかつ日光で $25^{\circ} \mathrm{C}$ 前後に温 めた水の中でクロレラを栽培する研究が行われてい る。もしこれが大規模に実施することに成功すれば， 将来の食料問題の解決にも有望視されている。

太陽光線によつて水を酸素々水素に分解する研究が 目下一部で盛に行われている。これは理論的にも可能 なことであり，もしこれに成功すれば太陽熱により水 素を作りこれをタンクに貯えておいて燃料として使 用することができる。従つてこの研究も非常に注目さ れている。

以上で一とおり太陽熱利用の趨勢について述へたの であるが，与えられた紙面が少いので充分に尽すこと ができなかつた。この問題について興味を持つ読绪は 日本機械学会誌の本年 5 月号の等者による同一題目の 記事を参照されたい。

\section{燃料に関する会合}

昭和 30 年は戦後 10 年間の産業技術の進歩々研究 活動の成果が示された年であり，この意味において燃 料に関する会合も充実し, 新しい魅力を加えた多くの 科学技術の進歩が示された年といえよう。特にわが国 からも代表の参加した国連主催の原子力平和利用国際 会議（8月ジュネーブ）においてェネルギの新しい 構想と原子力利用に狪連する幾多の問題が明らかにさ れるとともに，国内に捣てても各方面の会合で原子力 利用に関する討議が盛に行われたことは特記すべきこ とである。さてこの年に開かれた燃料関係の国際的会 合としては, 第 1 回国際火気活濁防止会議 ( 3 月, = ユーヨーク), 国際石炭組織学癿門討議会 ( 5 月, $\boldsymbol{y} 工$ ージュ), 第 1 回石炭科学国際会議( 5 月, ヘーレン), 万国内燃機関会議 $(5$ 月, ヘーグ), 第 1 回国際燃燒会 議 ( 6 月, ボストン), 第 4 回世界石油会議 ( 6 月, 口 一マ), 第 18 回化学連合総会拉よび第 14 回国際化学 会議 ( 7 月, チューリッと), 第 6 回国際ガス会讙 ( 9 . 月, ニューヨーク), 第 28 回工業化学国際会議(10月, マドリード), 第 1 回太陽エネルギ利用会議(11月，フ ェニクス)などをあげることができる。これらの会合 にはわが国から論交を携えて参玑したものもあり，そ の帰朝報告はいづれも有益なものであつた。なおフラ ンス鉱業協会創立百年記念大会が 6 月に多彩な催とと もに行われた。

つぎに国内における会合を観ると各方面において活 潑な活動が行われた。まず 1 月の本会恒例の新春特刷 講演会を皮切りとし，4月には日本化学会第 8 年会が 亰京て開かれ, 石炭関係 28 件, タール関係 15 件, 石油関係 27 件, 潤滑油関係 26 件の研究の発表があ り, また同月本会の低品位炭利用に関する特別講演会 と第 20 回コークス特別会が開かれた。 5 月には第 4 回全国炭硫幏術大会が東京て開かれ，6月には本会の 石油化学原料に関する特別講演会および第 21 回コー ク ス特別会(室蘭)のほか第 7 回東北熱管理大会(秋田) が開催された。7月には大阪において本会関西支部発 会記念会が盛大に催され, 東京において日本燃焼研究 会と化学機械協会共催の燃燒に関する講演会が開かれ 广。

このような会合は秋とともにますます活潑に行われ 9 月には世界石油会議報告講演会が世界石油会議日本 国内委員会の主催で行われ，10月には本会第 23 回大 会が宇部小野田地方で，また第 5 回全国選炭大会が東 京でそれぞれ行われたほか，中央熱管理協議会主催の 
媒煙防止座談会, 筃業協会主催の耐熱材粼, 原子炉用 黒鉛などに関するシンポシウムが開かれた。11月には 本会の石炭化学に関する特別講演会のほか, 大阪にお いて本会関西支部と日本油脂化学協会との共催の講演 会, 広島, 宇部地方て熱管理全国大会, また菓京で第 5 回品質管理大会が開かれたが，この種の大会は年中 行事として年を重ねるにしたがい盛大になつてきた。 一方この月には日本化学会, 日本石炭協会, 高分子学 会および本会共催の石炭に関する講演会と, 日本化学 会, 日本タール協会, 高分子学会, 有機合成化学扺上 び本会共催の石油およびュールタールに関する講演会 が日をついで行われ，それぞれ 14 件打よび 13 件の 研究発表が行われた。

以上の外本会の例会講演会, コークス技術罘談会, 石炭研究䈍談会の外, 講議会あるいは講習会て燃料に 関連する事項が取扱われたものは可なり多く，活気あ る 1 年であつた。特に 7 月に工業技術院長の要請によ り，石炭の有效利用を図る新技術開拓の目的をもつて 石炭の乾溜. ガス化抢よび新石炭化学に関する技術上 の問題点とその対策を研究するために設けられた石宸 化学技術慰談会 (委員長黒川本会会長, 委員学業界 20 氏）の調査審議の内容は各方面より注目されていたが その結果は 12 月 26 日石炭化学工業振興に関する意 見書として通商産業大臣に提出された。

\section{燃料に関連する規格}

A9501-1955 保温保冷工事施工標 Z9501-1952の改正 A9502-1955 石綿保温材 Z9502-1952 " A9503-1955 ケイソウ土保温材 Z9503-1952" A9504-1955 岩綿保温材技よび鉣 Z9504-1952" A9505-1955 ガラス繊維保温材 Z9505-1952" A9506-1955 孷酸マグネシア保温 Z 9506-1952， A9507-1955 崖化 ニルク板 Z9507-1952 A9508-1955 牛毛フェルトZ Z9508-1952 ,
C 9201 電 気 七 輪 新
C9202 電気ストーブ
C9206 電 気 ロ 一ス
C9207 電気卜ースタ
C9208 電気コーセー沸し器
D1002 无 $ᄌ$ 永生炍付自動車
走行滆験方法
E 8001-1955 産業用小形内燃機関

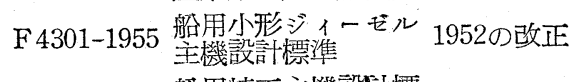
F 4302-1955 船用焼玉主機設䣓標
F 4303-1952 船用小形内燃主機関 1952 の確認

G3439 油井用継目 無釦管新

K1412-1952 粒 状活性岸 1952の確認

K1426-1952 活 性炭 (粉末) 石油製品引以点拉上

K2274-1955 び燃焼点矛土験方洼 放式試験方法)

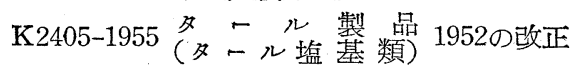

K2406-1955 (加エタ製品 ”

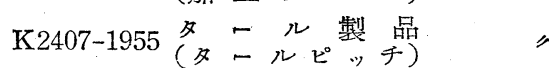

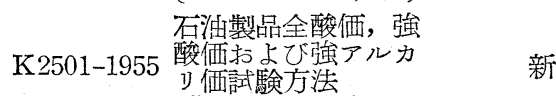
(婹試験方法

K2503-1955 石油製品ケン化価試

K2504-1955 新石溜製品沈デン価験方洼 "

K2505-1955 石油製品キョウ雑物駼方法 K2508-1955 石油製品希釈流動点

K2509-1955 航空潤滑油酸化安定 度就験方法

K2201-1955 工業用ガソリン1952の確認

K2202-1952 自動車用ガソリン

K2202-1952 不油製品反応試験方

K2253-1952 豆仧点試験方法 K2254-1952 ガソリン乑よび灯油，

K2255-1952 甭油掣方法

K2256-1952 アニリン点批㵓合

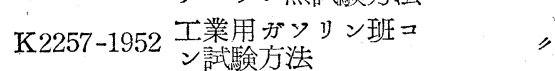

K2258-1952 否酒製品蒸気圧試験 "

K2259-1952 オクタン価測定試験， " 加鉛沓ソリン中の四

K2260-1952 エチル鉛定量試験方 1951 の改正 法

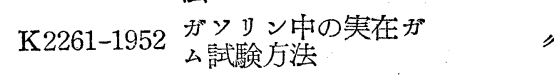

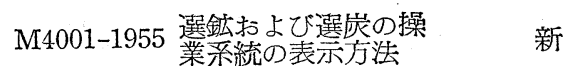

M8512-1952 耐火物験原料の耐火度 1952 の確認

M4601-1952 選炭用バケットエレ 1951の改正

R2201 耐火レンガの試料採 廃止

R2202-1955 耐火レンガの寸法の 1950 の改正

R2203-1955 耐火レンがのソリの "

R2204-1955 耐火レ弪試験方法の耐火点 


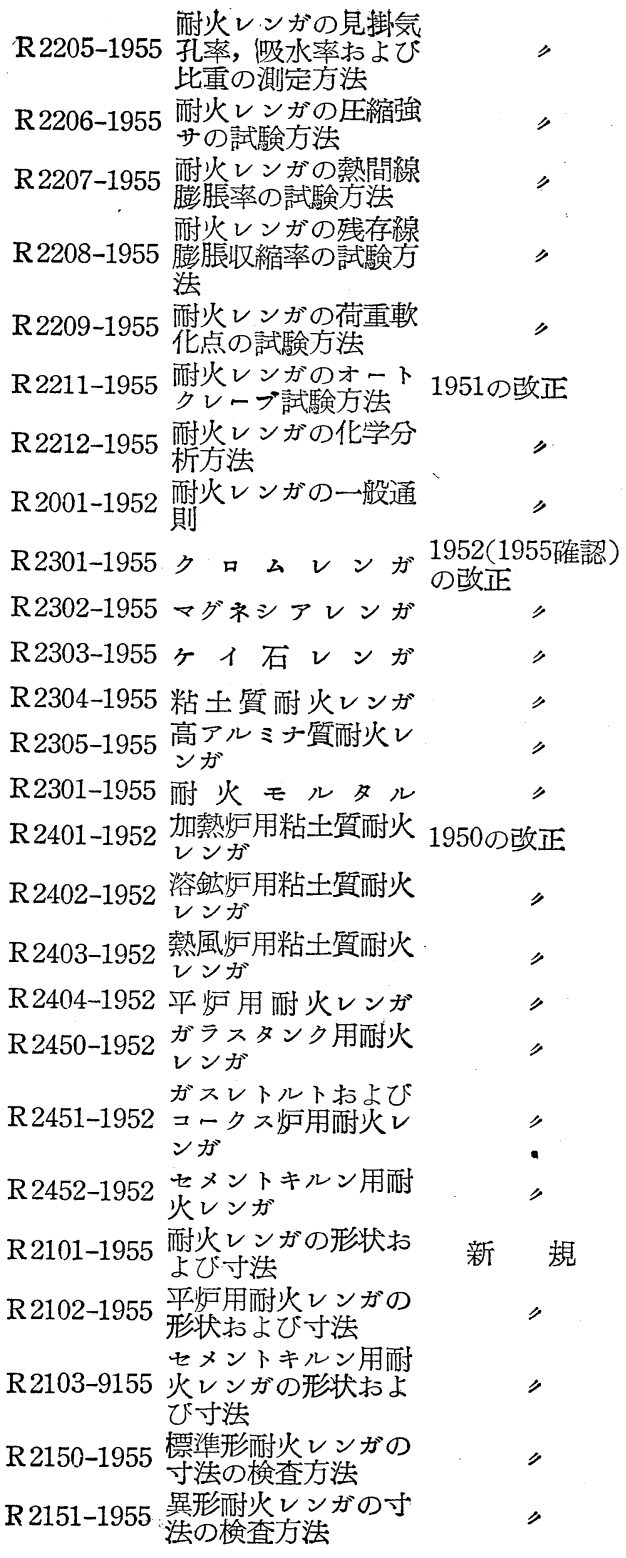

\section{然料に関する新刊書}

ジュラン，品質管理ハンドブック(今泉ほか訳)日科技 連 $985 \mathrm{p}$. 「日本規格協会 $507 \mathrm{p}$ シューハート，工業製品の経済的品質管理（白崎訳） 化学機械拹会, 最近の化学工学 九善 230p. 高压ガス協会, 交献高压化学工業 林 546p. レオントビチ, 蓺力学(三宅彰訳) みすが $177 \mathrm{p}$. 田中楠弥太, 熱抢よび熱伝達 技報堂 $194 \mathrm{p}$. 隈部一雄, 内燃機関学 山海堂 806p. 䲧打正一，舶用ジービル 同上 672p.
植田辰洋, ボイラ 朝倉 $240 \mathrm{p}$.

弘田亀之助, 蒸気ターービン入門, 電気畫院 104p. 山口交之助, 潤滑㧩と潤滑法, 山海堂 $333 \mathrm{p}$. 運輸省船員局, 潤滑油の添加剤とフラッシング $38 \mathrm{p}$. 中央熱管理協議会, 乾燥装置の実際 $63 \mathrm{p}$. 同, ボイラの熱精算方式々計測器標準配置 48p. 同, 熱管理士試験模範解答集 宮川ほか, 蹨料・熱管理工学 共立 $414 \mathrm{p}$. 総理府資源調查会, 日本のエネルギ資源 資源協会 資源協会，日本資源交献目録 $(1880 \sim 1950)^{*} 3300 \mathrm{p}$. 通産大臣官房調查統計部, 石炭・コークス統計年報*

日本石炭協会 230p.

*近刊

同，炭鉣設備切羽調查，同 $133,51 \mathrm{p}$ ( $\rightarrow$ 本誌 35 107) 日本石炭協会, 石炭鉱業の現状 32p. ( $\rightarrow$ 同上 34 509) 石炭年鑑 大同通信 $660 \mathrm{p}$.

備酒義雄，選㟶実技 白亜 556p.

高桑 健, 選炭工学(改版), 上 共立 280p. 金沢農地事務局, 酸性土磺に対する石炭の效果 $20 \mathrm{p}$. 北海,道農斌，泥炭地土性調査報告 V $49 \mathrm{p}$. 然料協会, コークス・ノート 155p. 同, コークスの研究, 日刊工業 $300 \mathrm{p}$. 通産省公益事業局, ガス事業統計年報 158p. 同, 電気事業の現状 (電力白書) 通産調查会 249 p. 通産省, 石油統計年報 石油経済研究会 204p. 同省軽工業局, 石油化学工業の概要 $72 \mathrm{p}$. 総理府資源調査会, アセチレン,さく酸, アセトン, 附カーバイト, 発こう, 石油化学工業資源協会 池辺清, 燃料工業と石油化学工業理工 237p. 飯车礼渚, 石油製品ガイドブック産業図書 350p. 外務省経済局第 5 課, サウード・アラ゙ビアの石油収益 附中東の石油 10p. ( $\rightarrow$ 本誌 34 447) $\lceil 45 \mathrm{p}$. 帝石調查部訳, 西ドイッ石油鉣業連合年報 (1953) プトナム (吉崎訳), エネルギ闍題の将来 同 538p. グラストン (金関ほか訳)，原子カハンドブック I〜 III（基礎，鉣石，炉）商工会館 506,408,512p. グラストンほか (伏見ほか訳), 原子炬理論, みすぶ จレー (杉本訳), 原子核工学, 丸善 $358 \mathrm{p}$. L364p. 原子力問題事典 (伏見ほか監修) 福音館 410p. 菊池ほか, 原子力工学講座 共立 近刊 $\lceil 225,34 \mathrm{p}$. 国会困書館，アメリカ原子力委寄贈文献目録 I 工業技術院，原子力平和利用海外調查団報告 $82 p$. Adlers, L., Liquid-Liquid Extraction. Elsevier. 206p.

$\lceil 428 \mathrm{p}$.

Am. Min. Congress, Coal Mine Mechanisation. Anselm, W., Der Drehofen Probleme der Ko- 
hlenstaubfeuerng. Bau-Verlag. 155S.

A. P. I., Petroleum Facts \& Figures. 11 ed. 322p. ASME, Power Test Codes. Solid Fuels. 52p.Г155p. ASTM, The 1955 Book of. Standards. Pt. 5.Fuels. -, Symposium on Coal Sampling. 160p.

-. Standards on Coal \& Coke. 164p.

-, Standards on Gaseous Fuels. 178p.

--, Symposium on Diesel Fuels. 56p.

Barth, W., Zyklonabscheider. VDI. 44S.

Baron, L. I., Silicosis. (Moscow) 396p.

Boileau, C., Chauffage et Rafraichissement Combinés des Habitations. Dunod. 313p. 「Lond.64p. Brit.Coke Res. Assn, Coke Review: July-Dec. 1954. Brit. Petroleum Equipment 1955/6. (Lond). 770p. (Brit.) Programme of Nuclear Power. Cmd 9389. 22p. ( $\rightarrow$ 本誌 34 303)

(同 34 559)

Brit. Stands Instn., Phenol. BS523: 1955. 15p.

Brooks, B. T. ほか (Ed.) Science of Petroleum.

III. Refinery Products. Oxford. 397p.

Burkov, G. A. (Ed.), Boiler Inspection Handbook. (Moscow) $5 € 8 \mathrm{p}$.

「Yale/Oxford. 353p.

Cassady, R., Price Making, etc. in Petroleum Industry, Colliery Yearbook \& Coal Trades Directory. 33 ed. Cassier 980p.

Colliery Guardian, Guide to Coalfieds. 522p. Combustion Researches \& Reviews.Butterworths. Cybulski, W., Safety of Explosives in Presence of Coal Dust. (Stalinogrod) 34p.

De Carls, J. A. ほか, Coke \& Coal Chemicals (Minerals Yearbook 1953, II, Prepr.) (Wash.) $62 \mathrm{p}$.

rVulcan. 329S.

Didier-K-H, Wörterbuch der Kokereitechnik.

Driggs, I. H. ほか, Gas Turbines for Aircraft. Ronald. $\$ 10$.

$\lceil 473 \mathrm{p}$.

Emmett, P. H. (Ed.), Catalysis. II. Reinhold. Esso, Bitumen, Verwend'g im Bauwesen, usw.23S.

Ferris, S. W., Handbook of Hydrocarbons. (N. Y.) $324 \mathrm{p}$.

Fontaine, R. La Conception du Chauffage. Sedec. $155 \mathrm{p}$.

「istry. (Lond.) 3 ed.

Francis, W., Boiler House \& Power Station ChemFreiberger Kolloqium, Chem. Kohlenveredelung. Akademie. 136S.

$\Gamma(K o ̈ l n) 48 \mathrm{~S}$.

Fuchs, W., Thermische Zersetz'g d. Kohle, usw.

Ges. f. Teerverwert'g mbH., 50Jahre-. $90 \mathrm{~S}$.
Gothan, W. 洁か, Lehrbuch d. Paläobotanik. Akademie. 535S.

Götte, A. (Ed.) Kokereiwesen. Vulkan. 135S.

Gröberほか Grundgesetz der Wärmeübertragung.

3 Aufl. Springer. 428S.

Grosskinsky, O. (Ed.), Handbuch des Kokereiwesens. I. Knapp. 547 S.

$\lceil 129 \mathrm{~S}$.

Grünzweig, Wärmetech. Taschenbuch. 17 Aufl.

Gumz.W.ほか, Die Kohle. Glückauf GmbH. 430 S.

Hamilton, R. W., Space Heating with Solar

Energy. M. I. T. $161 \mathrm{p}$.

Hayman, R. F. ほか Town Gas \& the Changing Needs of Industry. Instn. Gas Engrs. 30p.

Heinrich, F. J., Bituminöse Anstrichstoffe. III. Moser. 68S.

Henderson, P. L., Brown Coal. Melbourne. 351p. Hodge, J.,Cycles \& Performance Estimation (Gas Turbine Series) Butterworths. 329p.

ILO, Safety in Coal Mines. II. (Geneva).

India, Coal Board, Report of the Coal Washeries C'tee. (Calcutta)

-,一, Annual Report 1953-4. (同) 80p.

Internat'l C'tee for Coal Petrology, Proceedings. $61 \mathrm{p}$.

Int'l Conf. Peaceful Uses of Atomic Energy, Geneva, 1955, Proc. TFuels. 84p.

Inst. Petr, Engine Test Methods for Rating -., Standard Methods for Testing Petrolenm \& Its Products. 14 ed. (Lond.) 688p.

-, Modern Petr. Technology. 2 ed. 702p.

-, Reviews of Petr. Tech'gy. XIV. (1952 4)220p.

-, Glossary of Petr. Terms. 2 ed. 16p.

-, Applied Mass Spectroscopy. 333p.

Inst. Franc. Combus. et de l'Enrgiè, Journée du Depoussiérage des Fumies et Gas Ind'ls. 215p. Jahrbuch des Deut. Bergbaus. Glückauf $\mathrm{GmbH}$. 1438 S.

Jaromir, J., Modern Process for Fuel Gasification using Oxzgen. (Prague) $429 \mathrm{p}$.

Judge, A. W., Testing of High Speed I. C. Engines \& Gas Turbines. 4 ed. Chapman-H 494p.

Kates, E. J., Diesel \& Gas Engines. Chicago. 396p.

Kollmar, A. Heiz u. Lüftungsanlagen. 3 Aufl. Springer. 335S.

Kohlenhandel, Der, 1955. Glückauf GmbH. 303S. 
Ladenburg, R. W., Lewis, B., Pease, R. N. \& Taylor, H. S., High Speed Aerodynamics \& Jet Propulsion (Phys. Measurements in Gas Dynamics \& Combustion. XX.) Princeton. 578p. Lee, W. A., 30 Years of Coal, 1917-47.(Lond.)256p. Leloup, L., Etude de la Lubrication et Calcul des Paliers. Dunod. 294p.

$\lceil 302 \mathrm{p}$.

Liberation, etc. de l'Energie Nucleaire. Larousse.

Lieuwen, E., Petroleum in Venezuela. Univ. Calif. $160 \mathrm{p}$.

「Pétrole. (Paris) 408p.

Matériels d'Equipment pour l'Industrie du

Meldau, R., "Flugasche Fortuna I". VDI. 28S.

Mullen, P. W., Modern Gas Analysis. Interscience. $354 \mathrm{p}$. $\quad \Gamma$ (Stalinogrod) $20 \mathrm{p}$.

Nadziakiewicz, J., Problem of Coking Process.

Nat. Assoc. Coll. Managers, Indian Branch, Hydraulic Stowing in Indian Mines. (Lond.)

Nat. Smoke Abatement Soc., Yearbook 1955.52p.

Oechelhaeuser, K., Atlas der Technik des Gasfaches. Technik. 275S.

OEEC, Coal Industry in Europe. (Paris) 81p. -, Oil Requirement in Europe. (同) 136p.

-, Intra-European. Econ. Co-op. in Prodn \& Distr'n in Power. (同) 114p. 「p. (Schmidt) Persch, E, English-German Oil Dictionary. 564 Petr. Information Bureau, U. K. Petr. Ind. Statistics, 1953, 1954. 1955. (Lond.) 8p. 「252p.

Plaksin, I. N. ほか, Flotation of Coal.(Moscow)

Platon, J. G., Conduite dù Haut Fourneau. (Liège) $53 \mathrm{p}$.

Pletit, H., Energiewirtschaft. Oldenbourg. 206S. Popok, K.K. ほか Tech. Dictionary on Fuel \&Lubricants. (Moscow) 386p. Г(McGr-H) 531p. Powell, S. T., Water Conditiong for Industry. Reboux, P., Phénomènes de Fluidisation. (Paris) $165 \mathrm{p}$.

「Century Conf. (Wash.) 418p.

Resources for the Future, Inc., Report of Mid-

Reuschle, W., Schmier'g. 5. Aufl. Hauser. 89S.

Rossini, F. D. ほか, Phys. \& Thermodyn. Properties of Hydrocarbons, etc.1953. Carnegie.1050p.

SAE Handbook, 1955. 「Saar. Bielefeld. 420S.

Schuster, G., (Ed.) 200 Jahre Bergbau an der Schewe, J. H., Schmiermittel-Taschenb. Reuter. $125 \mathrm{~S}$.

「 Tson-W. 395p.

Schneider, P. J., Conduction Heat Transfer. Addi Sci. Lib., Use of Geothermic Power, 1928-53.
(Lond.) $2 \mathrm{p}$. 「ed. Chapman-H 50S. Semat, H., Intro'n to Atomic \& Nuclear Physics 3. Semjonenko, N. A., Abwärmeverwert'g (ロシア 語より訳), Fachbuch. 195S.

Severns, W. H. ほか, Steam, Air \& Power. 5 ed. Chapman-H. 502p. 「Mining. 2 ed.(Moscow) Shevyakov, L. D., Textbook on Russian Coal Shoemaker, R. W., Radiant Heat'g, incl. Geol. \& Heat Pump. 2 ed. McGraw-H. 346p.

Skinner, W. E. (Ed.) Oil \& Petr. Yearbook. 46 ed. (Lond.) 700p. $\quad$ II. (Moscow) 224p. Smekalin, I. V., Gazosnabzhenie (ガス生産) Some Fundamentals of Petr. Geol. Oxford. 139p. Spalding, D. B., Gas Turbine. II. Butterw. 250p. Spausta, F., Treibstoffe f. Verbrenn:-motoren. II. Springer. 482S. 「State Coll., Pa. 576p. Stephens, M. M. ほか, Natural Gas Engg. 3 ed. Stephenson, R., Intro' to Nuclear Engg. 387p. Struth, H. J. (Ed.), Intern'l Petr. Register. 32 ed. Palmer. 606p.; Wld Petr. Statis. 453p.

Tilicheev, M. D. (Ed.), Phys. \& Ch. Properties of Industrial Hydrocarbons. (Moscow) $490 \mathrm{p}$.

Tomkeieff, S. I., Coals, etc. : Nomencature \& Classification. Pergamon. 122p.

Trennende Mittel in der Steinkohlen-Aufbereitung. Steinhaus. 44S.

UN, ECAFE, Alcohol. in Asia (N. Y.) 445p.

-, ECE, Rep. C'tee on Elec. (Geneva) 11p.

--, - Report of the Coal C'tee, 1955. (同) $5 \mathrm{p}$. -, 一, Price of Oil in West'n Europe. (同) 50p.

U. S. Bur. Mines, Air Pollution Bibliogr. (18191952). Bull. 537. 448p.

Г544. 532p.

-, Fischer-T. Synthesis, etc., Bibliogr. I. Bull. -, Synth. Lig. Fuels. Ann. Rep. '54. I. Oil from Coal. R.I.5118. 73p. ; II. R.I.5119. 115p.

—, Size Distrib'n of Coke. R.I.5096. 40p.

U.S.Geol. Surv. \& A.E.C.,U in Coal. TEM784.26p. U. S. Steel Corp., Lubr'n Engrs' Manual. $\$ 5$. VDI, Wärmetechn. Arbeitsmappe. 7. Aufl.

VDI-Wärmeatlas. 183S.

「214S.

VDMA, Verbrenn'gsmotoren. Maschinenbau.

World Petroleum Congress, Rome, 1955. C.Colombo.

Worth G. Pneumokoniosen. Staufen. 898S.

Ziegs, K., Bitumen u. Asphalt-Taschenb. BauVlg. 440S. 


\section{勒 筆 者 名}

「炤和 30 年度における重要な燃料関係事項」は次の諸氏に調査, 執筆を打願い致しました。 石㞸鉱業の趨樊。 日 本 石 炭 協 会……吉 川 弘氏

石若に関する研究 資 源技術試 験 所……馬場有 政氏 コークス工業の趨勢

I 製鉄用関係 富士製鉄株式会 社……福

II 製鉄用以外. 日本 ガ. コークスに関する研究. 資 源 技 術 試 験 所……吉 永登氏 田雄”: 次氏 炭素に関する研究.

家庭然料の趨勢(燃料機具を含む)

暖房に関する趯勎（然焼装置および 媒煙防止死含む)

煉炭工業の遛勢.

鉄道用燃料の趨攀.

タール工業の趐勢.

タールに関する研究

都市ガ ス工業の罍㳹

ガス化学工業の遛勢

ガス化に関する研究

天然が ス利用の䞤勢

石油鉱業の趯勢。

石油精製業の趨勢.

ヘトロケミカルズの進展

石油に関する研究.

潤滑油に関する研究.

内然機関の遛勢. ガスタービンの進展

内燃機燃料の䀜勢.

汽力発生と楚焼法の趐勢

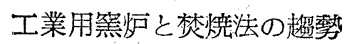

I 鉄 鋼 関 係.....

住友金属工䉾株式会社……福

II 鉄鋼関係以外

資源技術試 験 所……前

然焼に関する研究

品川燃料株式会 社……関

鉄 道 技 術 試 験 所……金

日本 タ - 几 協 会……矢

凟源技術試 験 所……需

日本 ガ ス 協 会……下

.佳友化学工業株式会社……正

資源技術試験 所……照

日本ガス化学工業株式会社……江

.東 京大学工学 部……藤

通鏟省鉣山局石油課……上

日本石油株式会 社……山

資源技術試験 所……雨

田英昌氏

藤 市 次 郎氏

日 進氏

戸 勲氏

松 正 世氏

毛 石 栄 造氏

宮藤 䆟氏

村一明氏

井 省 三民

井 秋 生氏

口 孝氏

井 清 光氏

原 益 夫民

田 省 二氏

营登亥氏

巻 直 臣氏

東京大学工学部……八 田 桂 三氏

運輸技術研觉所……中田金市氏

三蔆石油株 式会社……八 幡 武 三民

麗力技術研觉所……通 地信義氏

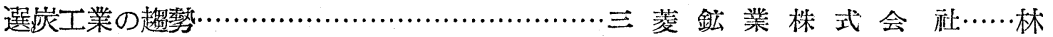

井真氏

沢昌武氏

泉 睦男氏

選炭に関する研究

資源技石試 験 所……伊集院 兼 正氏

蓺管理運動の超勢

……春 日

熱管理に関する研究.

…..山 田

動力源の調查開発に関する情樊.

原子力利用の趐勢 (ラジオアイソ

トープの利角を含む)

地熱発電の趨勢.

益事業 局調 查 課……都

築

進氏

太陽熱の利用の缹勢

子力研觉所……阿

部滋

燃料に関する会合\}

撚料に関寸る規格\}

慶応義塾大学工学部……谷

藤信

然料に関する新刊書

凟源技術試験 所……浅

市

岡 信 寿氏

……広田虎 雄氏

